\title{
Two Essays on the Land Tenure Institutions of Bulgaria: Evolution, Land Fragmentation and Land Productivity
}

\author{
By Natalia Boliari
}

A dissertation submitted to

The School of Public Policy and Administration

Carleton University,

Ottawa, Ontario

Canada

In partial fulfillment of the requirements for the degree of Doctor of Philosophy 


$\begin{array}{ll}\begin{array}{l}\text { Library and } \\ \text { Archives Canada }\end{array} & \begin{array}{l}\text { Bibliothèque et } \\ \text { Archives Canada }\end{array} \\ \begin{array}{l}\text { Published Heritage } \\ \text { Branch }\end{array} & \begin{array}{l}\text { Direction du } \\ \text { Patrimoine de l'édition }\end{array} \\ \begin{array}{l}\text { 395 Wellington Street } \\ \text { Ottawa ON K1A 0N4 } \\ \text { Canada }\end{array} & \begin{array}{l}\text { 395, rue Wellington } \\ \text { Ottawa ON K1A 0N4 } \\ \text { Canada }\end{array}\end{array}$

Your file Votre référence ISBN: 978-0-494-47472-3

Our file Notre référence

ISBN: 978-0-494-47472-3

NOTICE:

The author has granted a nonexclusive license allowing Library and Archives Canada to reproduce, publish, archive, preserve, conserve, communicate to the public by telecommunication or on the Internet, loan, distribute and sell theses worldwide, for commercial or noncommercial purposes, in microform, paper, electronic and/or any other formats.

The author retains copyright ownership and moral rights in this thesis. Neither the thesis nor substantial extracts from it may be printed or otherwise reproduced without the author's permission.
AVIS:

L'auteur a accordé une licence non exclusive permettant à la Bibliothèque et Archives Canada de reproduire, publier, archiver, sauvegarder, conserver, transmettre au public par télécommunication ou par l'Internet, prêter, distribuer et vendre des thèses partout dans le monde, à des fins commerciales ou autres, sur support microforme, papier, électronique et/ou autres formats.

L'auteur conserve la propriété du droit d'auteur et des droits moraux qui protège cette thèse. $\mathrm{Ni}$ la thèse ni des extraits substantiels de celle-ci ne doivent être imprimés ou autrement reproduits sans son autorisation.
In compliance with the Canadian Privacy Act some supporting forms may have been removed from this thesis.

While these forms may be included in the document page count, their removal does not represent any loss of content from the thesis.
Conformément à la loi canadienne sur la protection de la vie privée, quelques formulaires secondaires ont été enlevés de cette thèse.

Bien que ces formulaires aient inclus dans la pagination, il n'y aura aucun contenu manquant.

\section{Canada}




\begin{abstract}
This dissertation consists of two essays that address two distinct topics concerning the land tenure institutions of Bulgaria. The first essay studies the evolution of land tenure institutions, focusing on the period 1839-1944 during which the country experienced two distinct land tenure regimes - that of the late Ottoman Empire (1839-1878) and that of the post-liberation period (1878-1944). The major factors which determined the shape of these institutions are identified and analyzed by critically evaluating two theories of institutional change - the efficiency theory developed by Demsetz (1967) and the social conflict theory developed by Acemoglu, Johnson, and Robinson (2005). Consistent with the latter theory, the essay argues that political institutions and the distribution of resources determined the prevailing political balance which in turn determined the structure of land tenure institutions during 1839-1878. The process of institutional change was endogenous to the Ottoman Empire but exogenous to Bulgaria as the institutions of the latter were embedded into those of the former. During the 1878-1944 period, however, the initial source of prevailing political power was an external factor the Russian occupation forces. The essay suggests that the social conflict theory be expanded to include the embeddedness factor and the role of external factors in the process of institutional change.
\end{abstract}

The second essay studies the extent and underlying causes of land fragmentation in Bulgaria and its impact on land productivity. Multiple regression analysis is used to examine the relationship between land fragmentation and land productivity. The source of data for the study is the 2003 Bulgarian Multi-topic Household Survey. The findings of this essay suggest that: (1) in contrast to previous research, there is not enough evidence to conclude that land fragmentation in Bulgaria is driven by supply-side factors such as partible inheritance or population growth; (2) the level of current land fragmentation is low to moderate; and (3) this level of fragmentation is not likely to adversely affect land productivity. Other conditions being equal, therefore, land consolidation may not lead to any significant improvement in productivity in Bulgaria. 


\section{Acknowledgements}

This dissertation grew out of my desire to acquire the knowledge and develop the skills required to perform scholarly research in the study of institutions. Completing the dissertation was only possible with the help and support of several people to whom I hereby would like to extend my sincere gratitude.

I remain deeply indebted and grateful to my supervisor, Professor Saul Schwartz, for his trust in my abilities and efficient overseeing of the completion of my dissertation; for his invaluable teaching, guidance, ideas, and insights; continuous feedback, challenge, encouragement, and patience which were instrumental in my reaching the finish line. I owe a great deal of gratitude to my committee members, Professor Jean Daudelin and Professor Stephan Schott who shared their ideas, thoughts, and discoveries with me so generously, allowed me to incorporate those ideas in my writings, and patiently guided and challenged me through the dissertation process. I extend many thanks to my external examiners, Professor Marc Law and Professor Blair Rutherford, for their valuable feedback and suggestions. I thank the faculty and staff of the School of Public Policy and Administration who were always available and eager to assist and guide me throughout my studies. I am grateful to Carleton University and the Government of Ontario for providing academic support and financial assistance in my studies.

The research agenda of the dissertation was significantly affected by my attending the Ronald Coase Institute's Workshop on Institutional Analysis. I am indebted and grateful to the faculty of the Ronald Coase Institute for selecting me as a workshop participant 
and thus involving me in its community of outstanding scholars, for providing me with a fellowship, and for guiding and helping me build my capacity to analyze institutions.

I am grateful to the staff of the Department of Statistics of Households and Labour Force at the National Statistical Institute of Bulgaria, to the staff and faculty of the Institute of Agricultural Economics and of the Institute of Balkan Studies of Bulgaria for their incredible interest, assistance, and most accommodating attitude towards me and my work. I am particularly grateful to Ms. Desislava Dimitrova for taking the time to assist me in many ways and for greatly facilitating my work in Sofia. I am also particularly grateful to Dr. Ivanka Yanakieva for taking all the time to remain in contact and respond to my questions and for generously sharing her thoughts, research, and findings with me. I extend a special thank you to my dear friends, Tsvetanka and Teniu Stratievi for taking care of me during- and for adding fun and unique pleasure to- my stay in Sofia. I most earnestly thank my parents and brother for their endless support and belief in me.

To one person I give my deepest and most heartfelt gratitude: my husband, Kudret Topyan, for his patience and understanding, for his enthusiastic support, valuable ideas and comments on drafts, and for standing by me in the most challenging of times.

November 28, 2008 


\section{Dedication}

To my father and his inspiration, and

In loving memory of my grandfathers who struggled working the land of Bulgaria 


\section{Table of Contents}

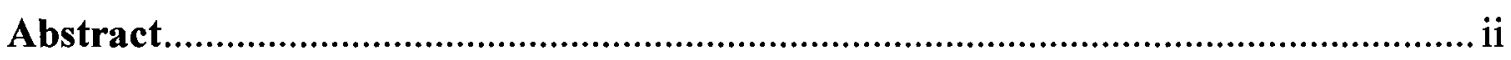

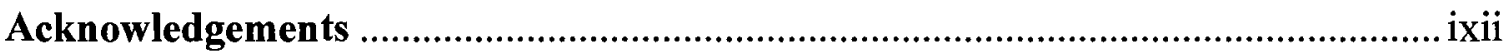

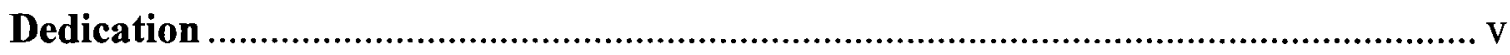

Table of Contents .................................................................................................. vix

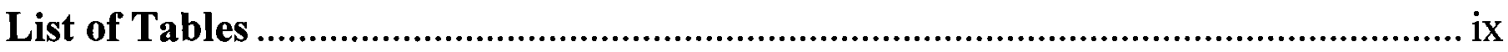

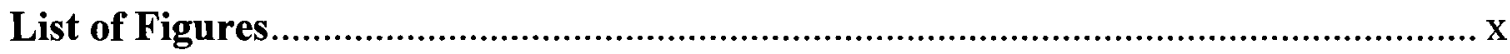

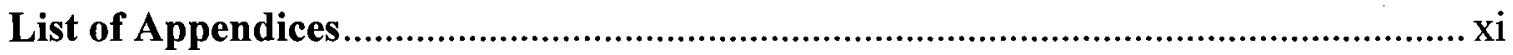

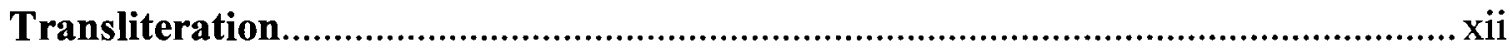

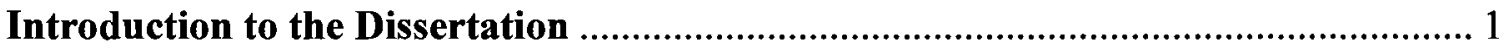

Essay I: The Evolution of Land Tenure Institutions: The Case of Ottoman and Post-

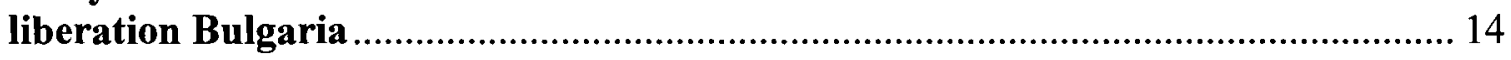

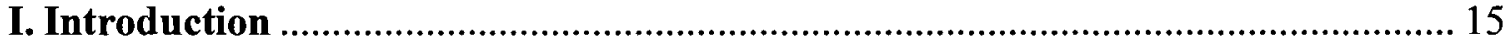

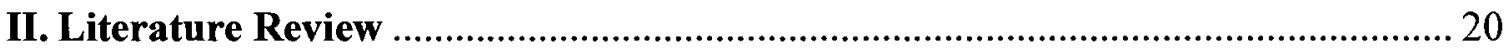

II. 1 Defining Institutions................................................................................... 20

II. 1.1 The Institutional Environment ………………........................................ 20

II. 1.2 Institutional Arrangements .................................................................. 23

II. 2 Land Tenure as a Property Rights Institution................................................... 24

II. 2.1 Historical Origins and Importance of Property Rights to Land ...................... 24

II. 2.2 Social and Political-Economic Aspects of Land Tenure.................................. 28

II. 2.2.1 Defining Land Tenure ............................................................................. 28

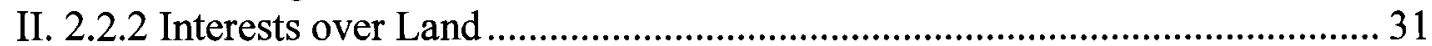

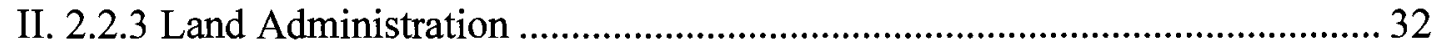

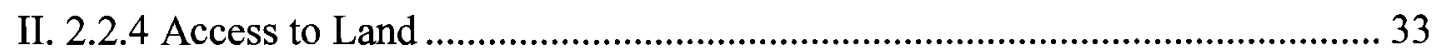

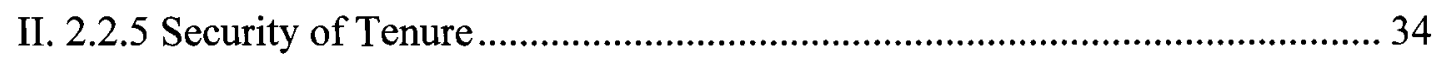

II. 2.3 Two Approaches to the Evolution of Property Rights to Land..........................36

II. 2.3.1 The Efficiency Approach ………………………………………………...... 36

II. 2.3.2 The Social Conflict Approach...................................................................... 42

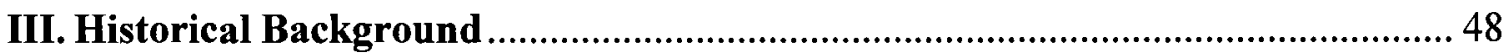

III. 1 The Ancient and Medieval Periods (681-1393) ........................................... 48

III. 2 Ottoman Rule and the Classical Ottoman Land Tenure Timar: 1393-1600 ... 52

III. 3 The Ottoman Informal Land Tenure System Çiftlik: 1600-1800 ..................... 61

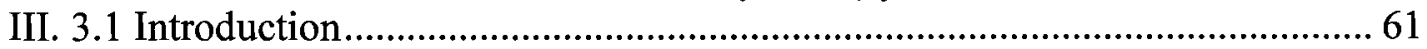




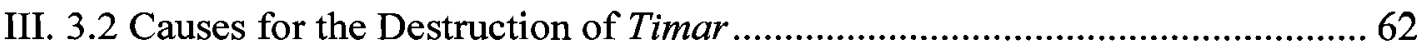

III. 3.3 The Emergence of the Çiftlik Land Holding System ..................................... 64

III. 3.4 Discussion of the Theories.......................................................................... 71

IV. The Evolution of the Late Ottoman Bulgaria Land Tenure: 1839-1878 …….... 74

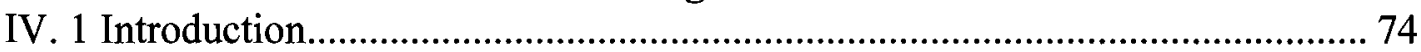

IV. 2 Description of the 1839-1878 Land Tenure Regime ...................................... 75

IV. 3 Discussion of the Theories........................................................................... 79

V. The Transition to the Post-liberation Land Tenure System of Bulgaria and its Evolution: 1878-1944

V. 1 The Transition to the Post-liberation Land Tenure Regime ............................. 90

V. 2 Discussion of the Theories............................................................................ 94

V. 3 The Evolution of the Post-liberation Land Tenure Regime: 1880-1944........ 101

V. 4 Further Discussion of the Theories with respect to the Post-liberation Period106

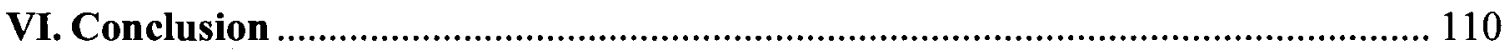

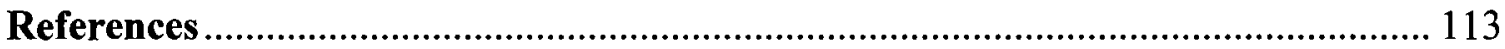

Essay II: Land Fragmentation and its Relation to Productivity .............................. 125

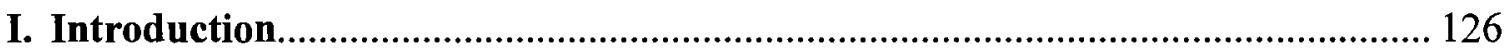

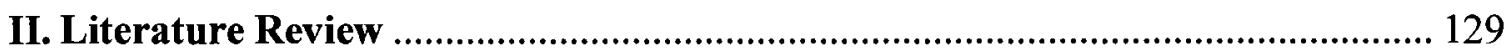

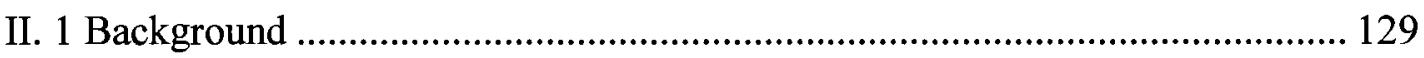

II. 2 Measures of Land Fragmentation...................................................................... 133

II. 3 Measures of Land Fragmentation in Bulgaria................................................. 137

II. 4 Causes of Land Fragmentation....................................................................... 141

II. 4.1 Supply-side Explanations............................................................... 142

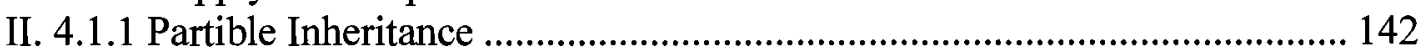

II. 4.1.2 Population Growth .................................................................................... 146

II. 4.1.3 Land Laws and Reforms ....................................................................... 150

II. 4.1.4 Change from Collective to Individual Ownership .................................... 155

II. 4.2 Demand-side Explanations ……………………..................................... 157

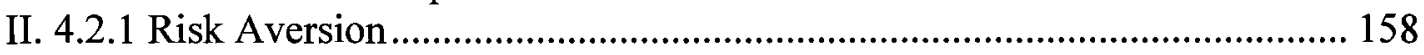

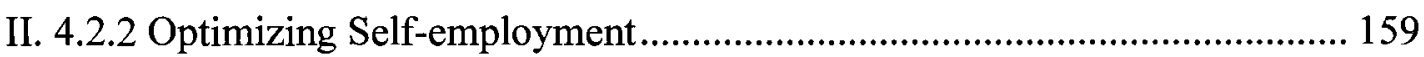

II. 4.2.3 Low Costs to Fragmentation ................................................................... 160

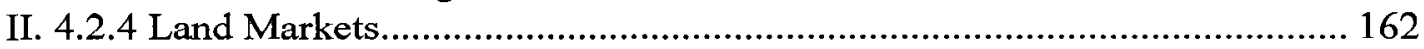

II. 4.2.5 Conservatism of Peasants........................................................................ 165

II. 5 Review of the Evidence on the Impacts of Fragmentation .............................. 167

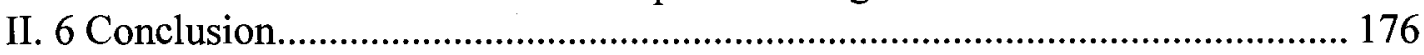

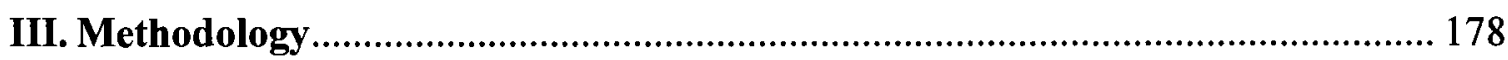




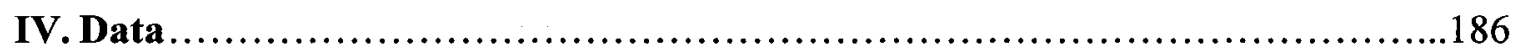

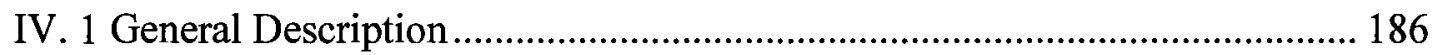

IV. 2 Determining the Level of Fragmentation ..................................................... 189

IV. 3 Further Description and Explanations of the MHS Data and Variables Included

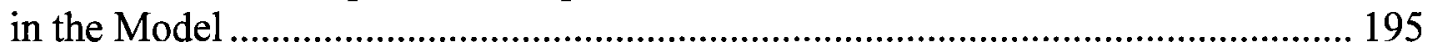

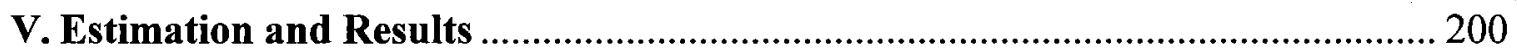

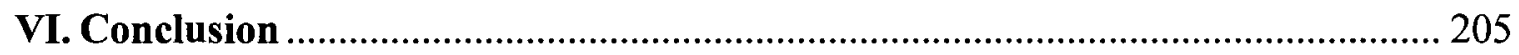

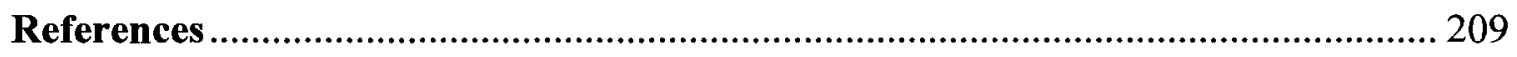

Appendix of Tables for Essay II ........................................................................... 217

Data Appendix

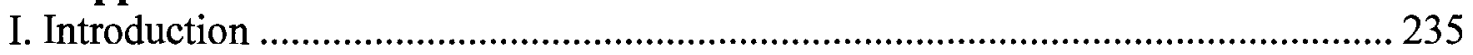

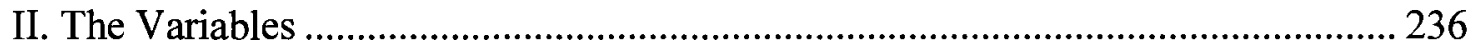

III. Creating the Relevant Subset of Survey Data...................................................... 237

IV. Deriving Data for the Individual Variables ........................................................... 238 


\section{List of Tables}

Table I. 1: Types of Property Rights to Land ................................................................ 20

Table I. 2: Distribution of Land Holdings by Size of Holdings in 1897 ......................... 97

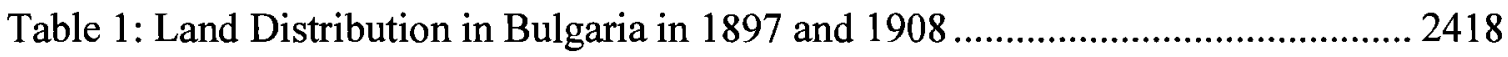

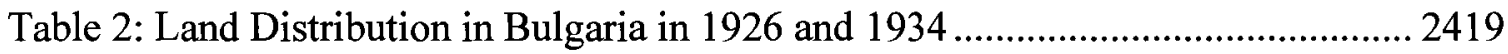

Table 3: Percentage Change in Land Distribution...................................................... 2420

Table 4: Selected Household Characteristics for the Samples of 1736 and 1293 ............ 24

Table 5: Selected Farm Characteristics for the Samples of 1736 and 1293 ................ 2422

Table 6: Distribution of Farm Size for the Samples of 1736 and 1293 ....................... 2423

Table 7: Fragmentation of Farmland in Bulgaria ........................................................ 24

Table 8: Selected Data Characteristics for Bulgaria ................................................... 2425

Table 9: Characteristics of Variables Used in the Model ............................................. 2426

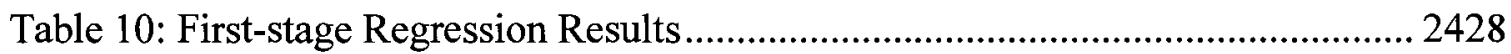

Table 11: Second-stage Regression Results ............................................................ 2429

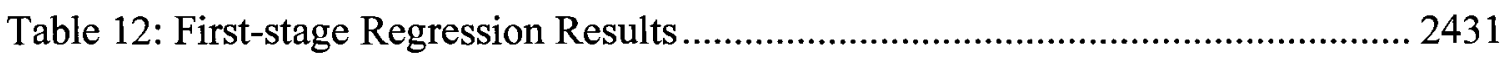

Table 13: Second-stage Regression Results ............................................................. 2432

Table A1: Prices Used in the Productivity Computation................................................. 247 


\section{List of Figures}

Figure II. 1: Distribution of Holdings According to the UAA .................................. 194

Figure A.1: Location and Size of Districts in Bulgaria ............................................. 248 


\section{List of Appendices}

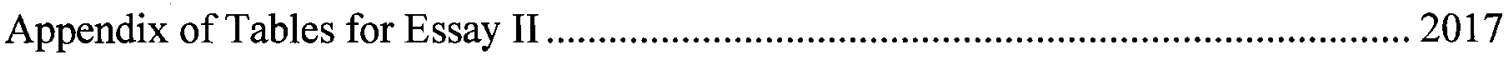

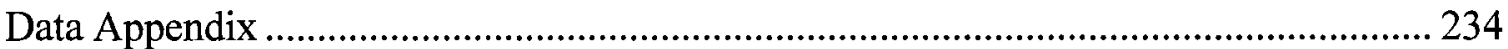




\section{Transliteration ${ }^{1}$}

\section{Bulgarian Alphabet and Romanization}

\section{Cyrillic U.S. Board on}

Alphabet Geographic Names

\section{Notes on Pronunciation ${ }^{2}$}

\begin{tabular}{|c|c|c|c|}
\hline A & a & a & shorter than ' $a$ ' in 'car', like the ' $u$ ' in 'bunker' \\
\hline Б & б & b & as in 'big' \\
\hline B & в & $\mathrm{v}$ & as in 'van' but as ' $\mathrm{f}$ ' in 'cliff' when final letter \\
\hline$\Gamma$ & $\Gamma$ & $\mathrm{g}$ & invariably hard, as in 'gate' \\
\hline Д & д & $\mathrm{d}$ & as in 'dog' \\
\hline $\mathrm{E}$ & $\mathrm{e}$ & $\mathrm{e}$ & as in 'met' \\
\hline Ж & ж & $\mathrm{zh}$ & as 's' in measure \\
\hline 3 & 3 & $\mathrm{z}$ & as in 'zoo' \\
\hline И & и & $\mathrm{i}$ & as in 'intellectual' \\
\hline Й & й & $\mathrm{y}$ & as ' $y$ ' in 'boy', occurring only in diphthongs \\
\hline $\mathrm{K}$ & 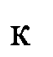 & $\mathrm{k}$ & as in 'king' \\
\hline Л & л & 1 & as in 'lad' \\
\hline M & M & $\mathrm{m}$ & as in 'man' \\
\hline $\mathrm{H}$ & $\mathrm{H}$ & $\mathrm{n}$ & as in 'no' \\
\hline $\mathrm{O}$ & 0 & 0 & as in 'or' \\
\hline$\Pi$ & п & $\mathrm{p}$ & as in 'pin' \\
\hline $\mathrm{P}$ & $\mathrm{p}$ & $\mathrm{r}$ & as in 'ran'; always pronounced as separate letter \\
\hline $\mathrm{C}$ & $\mathrm{c}$ & $\mathrm{s}$ & as in 'song' \\
\hline $\mathrm{T}$ & $\mathrm{T}$ & $\mathrm{t}$ & as in 'tin' \\
\hline $\mathrm{y}$ & $\mathrm{y}$ & $\mathrm{u}$ & invariably long as 'oo' in 'roof' \\
\hline$\Phi$ & $\phi$ & $\mathrm{f}$ & as in 'fox' \\
\hline $\mathrm{X}$ & $\mathrm{x}$ & $\mathrm{kh}$ & as ' $h$ ' in 'hunt' \\
\hline Ц & ц & ts & as in 'cats' \\
\hline Ч & ч & $\mathrm{ch}$ & as in 'cheese' \\
\hline Ш & III & $\operatorname{sh}$ & as in 'ship' \\
\hline щ & щ & $\operatorname{sht}^{3}$ & as 'shed' in 'wished' or 'finished' \\
\hline b & $\mathbf{b}$ & $"$ & $\begin{array}{l}\text { an indeterminate vowel, similar to that in the final } \\
\text { syllable of 'little' or as the ' } u \text { ' in 'turn' }\end{array}$ \\
\hline b & $\mathbf{b}$ & & as in 'yet'; not considered a separate letter \\
\hline Ю & ю & yu & as ' $u$ ' in 'use' \\
\hline Я & я & ya & as in 'yard' \\
\hline
\end{tabular}

\footnotetext{
${ }^{1}$ As suggested to use by the Chicago Manual of Style. The Library of Congress and the "Linguistic" System are using a slightly different transliteration.

${ }^{2}$ Examples as suggested by MacDermott $(1962,346)$. Only the pronunciation of ' $i$ ' is modified.

3 'shch' in Russian words.
} 


\section{Transliteration of Turkish Words}

The Turkish alphabet is a variant of the Latin alphabet and requires the following special characters:

\begin{tabular}{|c|c|}
\hline $\begin{array}{l}\text { Special Turkish } \\
\text { Characters }\end{array}$ & Notes $^{5}$ \\
\hline Ââ & $\begin{array}{l}\text { denotes lengthened vowel ' } a \text { ' or to palatize a preceding } \mathrm{g} \text {, } \\
\mathrm{k} \text {, or } \mathrm{l} \text {; invariably long as ' } \mathrm{aa} \text { ' in Maastricht }\end{array}$ \\
\hline $\mathrm{Cc}$ & 'j' as in 'juice' \\
\hline Çç & ch as in "cheese" \\
\hline$\breve{\mathrm{G}} \breve{g}$ & soft ' $g$ ', hardly or not pronounced \\
\hline İi & with a dot; as ' $i$ ' in 'intellectual' \\
\hline Il & $\begin{array}{l}\text { without a dot; as in the final syllable of 'little' or the first } \\
\text { syllable of 'earnest' }\end{array}$ \\
\hline Î̂ি & $\begin{array}{l}\text { denotes lengthened vowel ' } \mathrm{i} \text { ' or to palatize a preceding } \mathrm{g}, \mathrm{k} \text {, } \\
\text { or } \mathrm{l} \text {; as 'ee' in 'meet' }\end{array}$ \\
\hline Öö & as in the umlaut 'ö' in German or as French 'eu' in 'peu' \\
\hline ŞŞ & 'sh' as in 'sheet' \\
\hline Ûû & $\begin{array}{l}\text { denotes lengthened vowel ' } \mathrm{u} \text { ' or to palatize a preceding } \mathrm{g} \text {, } \\
\mathrm{k} \text {, or } 1 \text {; invariably long as 'oo' in 'boots' }\end{array}$ \\
\hline Üü & as in the umlaut ' $\ddot{u}$ ' in German or as French ' $u$ ' in 'tu \\
\hline
\end{tabular}

Note that there are dotted and un-dotted varieties of both the capital and the lowercase $i$. A dotted lowercase $i$ retains its dot when capitalized.

\footnotetext{
${ }^{4}$ As suggested by the Chicago Manual of Style.

${ }^{5}$ Examples mostly as suggested by Quataert (2005, xiv). Some additions made by the author. 


\section{Introduction to the Dissertation}

This dissertation consists of two essays that address two distinct topics in relation to land tenure institutions. The first topic concerns the evolution of land tenure institutions and the second concerns the nature of land fragmentation and its relation to land productivity. Given that each society's institutions are unique, developing out of historical— social, political, and economic - patterns, they require an investigation on a case by case basis. The research on both topics focuses on Bulgaria, an Eastern European country in transition from a socialist centrally planned to a capitalist market economy.

The objectives of the dissertation are: (1) to contribute to a better understanding and assessment of the complex nature of the evolution of local land tenure institutions by critically evaluating existing theories of institutional change; (2) to contribute to a better understanding of the nature and causes of land fragmentation by critically evaluating existing evidence; (3) to test the impact of land fragmentation on land productivity; and (4) to inform policies designed to improve land tenure institutions as well as policies designed to combat land fragmentation.

Issues related to land tenure institutions have figured prominently on the development agenda as a result of post-socialist countries' introduction of radical land reforms in the early nineties as well as the introduction of land reforms in various developing countries in Africa, Asia, and Latin America. The 1990s land reform in Bulgaria took the form of land restitution which required the massive transfer of land rights from state or collective 
units to private parties, often the former owners of the land or their heirs. In the wake of the reform, the seemingly inequitable and improper distribution of the land and the lack of clear definition, enforcement, and security of land rights have emerged as important problems. Moreover, concerns over land fragmentation, a historical feature of Bulgarian agriculture that is often viewed as a major issue, re-emerged as a direct outcome of the reform. These problems are considered to be responsible for the poor functioning of land markets and low levels of agricultural land productivity in the country.

Appropriate and effective policy solutions to the above problems require: (1) coming to understand the underlying, fundamental bases for the current structure of Bulgarian land tenure institutions by systematically examining their nature and evolution; (2) understanding the underlying causes for land fragmentation in the country; and (3) the accurate measuring of land fragmentation and assessing its impacts on productivity or other economic outcomes. Insofar as Bulgaria is concerned, these three distinct areas of research have received little attention despite an increasing recognition of their significance in the literature. Filling this research gap is, therefore, the underlying motivation for this dissertation.

\section{Introduction to Essay I: The Evolution of Land Tenure Institutions: The Case of Ottoman and Post-liberation Bulgaria}

More than thirty years ago, Alchian and Demsetz (1973) pointed out that the growing literature on property rights institutions suggests the challenging question of how a 
particular property rights structure comes into being. Historical comparative and case study research has shed light on this question; however, given the many differences between nations and their histories and economies, it is not surprising that there is a lack of any standard answer. Essay I of the dissertation is motivated by the above question and establishes the first central research question of the dissertation as follows:

\section{What are the critical factors which determined the shape of the agricultural land tenure institutions of Bulgaria and influenced their evolution?}

This question is addressed through a critical evaluation of two major theoretical frameworks in the institutionalist literature, those provided by Demsetz $(1967)^{6}$ and Acemoglu, Johnson and Robinson (2005). ${ }^{7}$ Both theories view the process of institutional change as an endogenous phenomenon but differ fundamentally in their identification of the principal causes of that change. While Demsetz's underlying forces of institutional change are "the desires of the interacting persons for adjustment to new benefit-cost possibilities", Acemoglu, Johnson and Robinson's fundamental determinants of institutional change are the political institutions and distribution of resources in society at a particular time.

The essay is constructed as follows. Following a brief introduction, it starts with a literature review section which describes the theoretical framework of the study. This

\footnotetext{
${ }^{6}$ Demsetz, Harold. 1967. Toward a theory of property rights. American Economic Review 57 (2): 347-359. ${ }^{7}$ Acemoglu, Daron, Simon Johnson, and James A. Robinson. 2005. "Institutions as the Fundamental Cause of Long-Run Growth." In Handbook of Economic Growth, ed. Philippe Aghion and Stephen Durlauf, 385472. Amsterdam: North-Holland.
} 
section defines the concepts of institutions, property rights, and land tenure; reviews the historical origins and importance of property rights to land; discusses the social and political-economic aspects of land tenure such as interests of interacting parties, access to land, land administration, and security of land tenure. Next, the section summarizes and discusses the two theories developed to identify and address the driving forces behind institutional change. As mentioned above, both theories view the process of institutional change as an endogenous phenomenon and leave aside the possibility that the relevant factors may not lie within the society whose property rights regime is being considered. The discussion of the evidence on the land tenure institutions of Bulgaria challenges this view and suggests that exogenous factors may play a critical role in shaping the institutions of a society. Moreover, the case of Bulgaria brings the possibility that "local" regimes are embedded into broader ones whose economic efficiency, rent-seeking or other conflict dynamics are crucial.

The essay continues with a section devoted to a brief historical overview of Bulgarian land tenure institutions existing prior to $17^{\text {th }}$ century and a more detailed discussion of the period between $17^{\text {th }}$ and $19^{\text {th }}$ centuries. The goal of this section is to provide the reader with background on the evolution of land tenure in the $19^{\text {th }}$ century, an evolution which constitutes the actual focus of analysis. While critical evaluation of the evidence on the evolution of land tenure institutions prior to $19^{\text {th }}$ century falls outside the scope of analysis, the section makes several comments on this evidence as it relates (or does not relate) to either of the two theories. For example, as a result of the 1393 Ottoman conquest of Bulgarian lands, the local, Byzantine type, feudal land tenure institutions of 
Bulgaria were immediately and completely destroyed. In their place, the Ottoman central government introduced and enforced its own land tenure system, called timar $^{8}$, which featured state ownership of arable land on the basis of Islamic jurisprudence and where access to land rights and their administration was under the strict politico-military control of the central authority. This system was developed entirely outside the native institutional environment of Bulgaria, in a socio-economic-politico-religious context completely foreign to that of Bulgarian society. As absolute Ottoman power ascended following the conquest of Bulgaria, so did the Ottoman institutions of land tenure. In other words, institutional structures developed in one context, that of Ottoman society, were carried over to another context, that of Bulgarian society. In this respect, the radical change in the land tenure institutions that occurred in $15^{\text {th }}$ and $16^{\text {th }}$ century Bulgaria resulted from a completely exogenous factor - Ottoman military dominance and subsequent Ottoman hegemony. Such an institutional change is difficult to define as an endogenous process and thus Bulgaria does not conform in this period to either of the two theories of institutional change.

The following section of the essay critically evaluates the process of transition to the land tenure institutions introduced in the mid $-19^{\text {th }}$ century, their features, the transition to the early $20^{\text {th }}$ century land tenure institutions and the developments in the latter. In 1858 the Ottoman central government legally introduced individual property rights to land in Northern Bulgaria. This partial introduction of individual property rights to land was an essential part of the empire-wise institutional reorganization period known as Tanzimat. The evidence presented in this section conforms generally to the theoretical framework

\footnotetext{
${ }^{8}$ Refer to Transliteration: " $\mathrm{i}$ " is pronounced as in intellectual and " $\mathrm{a}$ " is pronounced as in mark.
} 
put forth by Acemoglu, Johnson and Robinson (2005): the political institutions and distribution of resources in the Ottoman Empire were the crucial determinants of this process.

However, there are important issues which the theoretical framework fails to explain. First, these determinants were still exogenous to Bulgaria, which, being an integral part of the empire, did not have its own political institutions and, generally lacked the resources necessary to acquire any significant political or economic power. Second, the reasons for which property rights to land were introduced did not directly relate to the concern of maximizing the rents of the Sultan and his administration, which represented the group in political power. Rather, they were directly related to critical changes in the international environment which greatly affected the wellbeing of the Empire and which the central Ottoman government in Istanbul could not ignore. Third, the strength of political power may not be sufficient to maintain the life of desired property rights institutions. The social conflict theory of Acemoglu, Johnson, and Robinson says nothing about what happens when the group in political power fails to implement their institutional reforms as they were planned. The central Ottoman administration had difficulties in introducing individual property rights to land in other parts of the empire and it struggled to maintain those rights wherever they were introduced. There are two important reasons for this: the lack of institutional capacity and lack of competence of the ruling elites. Private property rights were an institution borrowed from Western Europe and their proper assignment, monitoring, and enforcement required a particular institutional capacity which the empire lacked. And since they were introduced from top 
to bottom, the training and competence of the ruling elites were of crucial importance for their successful implementation. The evidence suggests that such competence was lacking. In spite of the seemingly genuine desire of the Sultan and his administration to follow the footsteps of the West, the introduction and implementation of private property rights were greatly limited.

Furthermore, the process of transition from the late $19^{\text {th }}$ century Ottoman land tenure to the post-liberation land tenure was an endogenous process as it emerged as a result of spontaneous peasant actions which ultimately laid the foundations of the new pattern of landownership. But it was also a process that was only possible to achieve through an exogenous mechanism - the Russian victory in the Russo-Turkish War of 1877-1878. Bulgarian peasants acquired the power to overturn the Ottoman land tenure regime as a result of the Russian victory and with the full support of the Russian occupation forces in the country. The endogenous nature of the process conforms to both theories. Neither theory, however, can explain the critical exogenous mechanism involved. Demsetz's theory does not elaborate on any type of mechanism by which the transition to the presumably more efficient property rights regime occurs. Acemoglu, Johnson, and Robinson's theory, on the other hand, does not include the possibility that political and economic power may be derived from a source exogenous to a society. Nevertheless, the latter theory appears to be effective in organizing the factors that determined of institutional change in the early $20^{\text {th }}$ century. Therefore, the evolution of Bulgarian land tenure institutions can be explained by expanding the social conflict theory to include the 
embeddedness of local regimes in broader ones and by accounting for the role of exogenous factors. 


\section{Introduction to Essay II:}

\section{Land Fragmentation and its Relation to Land Productivity}

The second central research question of the dissertation, addressed in Essay II, concerns a phenomenon which is sometimes considered a direct outcome of the 1991 land reform of Bulgaria - land fragmentation, defined as the situation where a single farm is composed of more than one separate plots of land. Land fragmentation ${ }^{9}$ is an important agricultural land tenure issue because it is believed to give rise to agricultural inefficiency, and, in particular, to the inefficient use of land, labour, capital, and other resources. However, empirical studies conducted in various countries provide mixed evidence on the impact of fragmentation on economic outcomes.

While the study of Bulgarian land fragmentation in the literature is rather limited in scope and while there is no solid evidence documenting the negative effects of land fragmentation on agricultural productivity in the country, the Ministry of Agriculture and Food Supply initiated a number of projects in the early 2000 s to develop policies for farm land consolidation. The absence of such evidence is the motivation for the second essay which sets its central research question as follows:

\section{Does land fragmentation in Bulgaria affect land productivity?}

\footnotetext{
${ }^{9}$ As will be emphasized throughout Essay II, it is important to distinguish land fragmentation from the formation of small-sized farms. As defined above, land fragmentation refers to the situation where a single farm is composed of more than one separate plots of land. This is different from the process of division of land into small farms. For example, if all the farmers of a village posses farms composed of one single small parcel of land, their land is not viewed as fragmented. As long as a farmer possesses one single plot of land, regardless of its size, his land is considered consolidated.
} 
The question is addressed through the use of multiple regression analysis to estimate the link between land fragmentation and land productivity.

The essay starts with a comprehensive literature review of the nature, measurement, underlying causes, and impacts of land fragmentation in general and as they relate to the case of Bulgaria. The analysis of the causes of land fragmentation in Bulgaria shows that there is not enough evidence to conclude that it was historically driven by supply-side factors such as partible inheritance or population growth, even though together with government-initiated land reform policies these factors may have contributed to its extent in the first half of the $20^{\text {th }}$ century. In other words, there is not enough evidence to conclude that Bulgarian land fragmentation is an exogenous phenomenon, one determined by factors other than the behaviour of the farmers.

Further analysis of the causes of land fragmentation suggests evidence that demand-side factors such as the risk-aversion of farmers, the goal of farmers to optimize selfemployment, the low costs of fragmentation, and peasant conservatism had influenced the emergence and persistence of fragmentation. This implies that land fragmentation in Bulgaria might be an endogenous phenomenon, one that is desired by farmers. The development of land markets, which can be considered a mix of supply- and demandside factors, stands out as the factor having most influence on the level of fragmentation in the country. Taken together, these findings suggest that farmer's behaviour has to be taken into account in the study of fragmentation. Further and deeper research on these 
causes would prove useful in terms of increasing our understanding of fragmentation in Bulgaria and thereby developing the relevant criteria for policy selection and design.

After reviewing the literature, the essay proceeds with a description and discussion of the data, methodology, and results of the study. The source of data for the study is the most recent, nationally representative 2003 Multi-topic Household Survey (MHS) performed by the National Statistical Institute of Bulgaria under the auspices of the World Bank. Using the MHS data, the level of current fragmentation was measured by the Simmons Index (one of several fragmentation measures) and the number of parcels per farm. Both indicate a relatively low level of fragmentation which is contrary to the general belief that this level is alarmingly high. In the literature, fragmentation is often incorrectly viewed as the division of agricultural land into small farms or the prevalence of small landownership. Therefore, it is often measured as the percentage of small farms which, indeed, is high in Bulgaria. However, the issue of undersized farms is one that is separate from the issue of fragmentation and throughout the study attention is drawn to the need to clearly differentiate between the two. Fragmentation can also be measured by simply dividing the total number of plots in the country by the total number of farms to obtain a national average of the number of plots per farm. But such measurement is too general and can lead to overestimation of the actual level of fragmentation. Further improvement to the measurement used in this study may be achieved by calculating the Simmons Index on a district by district basis. 
The econometric model of the study is based on the model developed by Blarel et al. (1992). The model specifies the relationship between a set of household decision variables, sets of parcel-specific, household-specific, and district-specific characteristics on one hand and the dependent variable, parcel yield (measured as the total value of harvested crops per decare ${ }^{10}$ ), on the other. Results presented here show that the level of fragmentation measured by the 2003 data is not likely to adversely affect land productivity. Distance from the homestead to parcels seems to significantly affect productivity, indicating that cost of travel time is a matter of concern. However, a considerable majority of parcels are closely located to the household's homestead so the cost of travel time can be negligible. Furthermore, this distance seems to negatively affect the level of fragmentation which implies that the shorter the distance, the more likely is that fragmentation will occur.

The most important finding in Essay II is that the level of land fragmentation as measured by the 2003 MHS data is so low that it may not require the implementation of consolidation policies, at least not on a national level. Furthermore, other conditions being equal, such a policy solution is unlikely to improve land productivity in Bulgaria since the study shows that fragmentation is not likely to adversely affect productivity. It is possible however that some districts in Bulgaria may be more fragmented than others and that the negative effects of fragmentation on productivity may be a matter of concern in such districts. In such cases, consolidation policies, if desired by farmers, may be considered as a solution.

\footnotetext{
${ }^{10}$ Decare is the land area measurement unit used in the MHS data and commonly used in Bulgaria. 1 decare $\approx 1000$ sq. $\mathrm{m} ; 1$ decare $\approx 0.25$ acres
} 
The overall message of Essay II is that fragmentation in Bulgaria at present is not the problem that most researchers think it is. Insofar the level of fragmentation is of concern, it is often said that the radical land reform initiated at the outset of the transition from a socialist to a capitalist economy brought the country back to a stage similar to the one where it was before the communist regime. The study shows that this is not the case; the decline in the level of fragmentation in the post-communist period is astounding and brings an interesting question for future research: What are the possible factors that determined this decline? The prevalence of undersized farms may be a problem at the present but policymakers must distinguish the issue of fragmentation from the issue of undersized farms and be clear about which problem they are addressing. Better understanding of the underlying causes for the current problems in relation to land productivity is necessary in order to target correctly the areas which require policy intervention for change and improvement. 


\section{Essay I}

The Evolution of Land Tenure Institutions: The Case of Ottoman and

\section{Post-liberation Bulgaria}




\section{Introduction}

In the field of New Institutional Economics (NIE) ${ }^{11}$, institutions are defined as "the rules of the game in a society or, more formally, [as] the humanly devised constraints that shape human interaction" (North 1990, 3). Since Coase's (1937; 1960) analyses of the nature of the firm and of the problem of social cost, North and Thomas's (1973) and North's (1981) analyses of the causes of economic growth and performance, the study of institutions has arisen as, and continues to be, a promising field in which to explore the origins of development or underdevelopment. ${ }^{12}$

\footnotetext{
${ }^{11}$ The term New Institutional Economics was introduced by Williamson $(1975,1)$ to differentiate the current approach to the study of institutions in the original institutional economics school of thought. Born within and building on the framework of neoclassical economics, the NIE modifies and extends the neoclassical theory by attempting to incorporate a theory of institutions into economics (North 1995, 17). As North emphasizes, while keeping the assumption of the neoclassical orthodoxy that self-seeking individuals attempt to maximize objectives under scarcity and hence competition, the NIE relaxes the assumptions of instrumental rationality, zero transaction costs, and perfect information. The facts that in the real world information is imperfect, and that, due to their different mental models, individuals perceive and view differently the workings of this world, is the starting point which brings the NIE to the concept of transaction costs (Harriss, Hunter, and Lewis 1995, 3). Transaction costs are broadly defined as the costs of obtaining relevant information on prices, of negotiating, concluding, monitoring, and enforcing contracts. The level of these costs is determined by the institutions and institutional arrangements of societies which thus are viewed as the means of reducing information and transaction costs (Harriss, Hunter and Lewis, 3 ). Therefore, it is hypothesized that the institutions of a country such as its legal systems, property rights, and organizations, both political and economic, are the key determinants of its economic performance (North $1990 ; 1995)$. With this new direction, the NIE aims to explain what institutions are; what the determinants of institutions are; how institutions emerge, evolve and change; what purposes they serve; how they affect economic performance, efficiency and distribution; and, if necessary, how they should be reformed (Klein $2000,456)$.

${ }^{12}$ The social sciences literature offers many diverse approaches to the conceptualization, modeling, and analyzing of institutions. Through a variety of theories and methodologies scholars from different schools of thought have sought to explain issues such as whether, why, and in what way institutions matter for development; how institutions evolve and change; why institutions differ across economies and societies; how they affect the economic and political performance of societies; and what critical factors, endowments, policies, or arrangements have led institutions to develop or evolve in the way they have. Despite the differences in methodologies, there seem to be a consensus among scholars that institutions have a significant impact on the economic development of societies. For a detailed review see Acemoglu, Johnson, and Robinson (2001, 2002a, 2002b, 2005a, 2005b); Clague et al. (1997); Davis and North (1971); Eggertsson (1990); Engerman and Sokoloff (2001); Furubotn and Richter (1997); Hall and Soskice (2001); Knack and Keefer (1995); North (1981, 1990); North and Thomas (1973); North and Weingast (1989); Olson (1965); Ostrom (1990); Rodrik (1996, 1999a, 1999b); Rodrik, Subramanian and Trebbi (2004); Streeck and Thelen (2005); Williamson (1985, 1994, 2000).
} 
The emergence and evolution of economic institutions, such as property rights, is a phenomenon that institutional economists have explained in different ways. ${ }^{13}$ A well known and much followed theoretical framework on the evolution of property rights is provided by Demsetz (1967) who argues that “... the emergence of new property rights takes place in response to the desires of the interacting persons for adjustment to new benefit-cost possibilities." According to this theory, economic reasoning is the main driver of institutional change: 'calculating' the costs and benefits of economic institutions, interacting individuals tend to choose those property rights arrangements which are more beneficial or efficient for them.

Another theoretical framework was recently provided by Acemoglu, Johnson and Robinson $(2005 b)^{14}$ who argue that economic institutions are most often chosen by the groups in control of political power in a society at a given time. Since these groups are usually concerned with maximizing their own rents, they will choose to introduce those economic institutions which will provide the greatest benefits for themselves, rather than those which will provide the greatest benefits for the society as a whole. In other words, the driving forces of institutional change in society are the distributional consequences and implications of economic institutions which would maximize the utilities of the ruler or political power at a particular time.

\footnotetext{
${ }^{13}$ See Blum (1957), Boserup (1965), Deininger and Feder (1999), Domar (1970), Libecap (1989), North (1981), North and Thomas (1973), Pettengill (1979).

${ }^{14}$ From now on the joint works of Acemoglu, Johnson, and Robinson will be referred to as AJR.
} 
No matter how different the two theories, they share one significant feature in common: both view the institution of property rights as being endogenous, that is, as emerging within society. The theory of Demsetz has met with skepticism and has been criticized primarily for its failure to (1) define the factors that determine the costs of a property rights regime and the form that emergent property rights are likely to take (Merrill 2002); (2) specify the mechanisms by which the transition from one property rights regime to another actually occurs (Banner 2002); (3) take into account the role of the state and the political processes involved in the creation of property rights (Field 1981; Libecap 1986, 1989; Wyman 2005); and (4) explain the pervasive presence and persistence of inefficient institutions across societies (AJR 2005b). As a rather newer contribution to the literature of institutional change, the plausibility of the theory of AJR (2005b), on the other hand, remains to be evaluated in the literature.

The lack of a consensus on the ways in which the institution of property rights emerges and evolves is the motivation for this essay. The rather turbulent history of land tenure institutions in Bulgaria presents one specific example of the evolution of the institution of property rights to land. The goal of this essay is to use this example in order to critically evaluate the evidence on land tenure institutions as it relates to the theories of Demsetz and AJR.

In the period from the mid-1 $19^{\text {th }}$ century to the present, Bulgaria experienced four different systems of land tenure institutions. They can be defined as the land tenure of: (1) the late Ottoman Bulgaria, which lasted from 1839 to 1878 ; (2) post-liberation Bulgaria, which 
lasted from 1878 to 1944 ; (3) communist Bulgaria, which was in place between 1944 and 1989; and (4) transitional Bulgaria, which was introduced in 1991 and continues to the present. Three major shifts in land tenure institutions in a span of 150 years offer an interesting example of the evolution of land tenure institutions. The analysis of all four regimes and the three transitions between these regimes would be a valuable contribution to the literature of institutional change. For the purposes of this essay, however, only the first two regimes and the mechanisms of transition between them will be examined. The subsequent two transitions will be subject for future research.

The objectives of the essay are: (1) to identify the major factors which influenced the decisions to reallocate property rights to land during the third quarter of $19^{\text {th }}$ century and the beginning of $20^{\text {th }}$ century; (2) to identify the mechanisms which provided for the shift from the first to the second set of land tenure institutions; and (3) parallel to these goals, to critically evaluate the evidence on the land tenure institutions of Bulgaria as it relates to the above mentioned two theories of institutional change.

The essay is organized as follows. Section II provides a literature review which includes a discussion of land tenure institutions within the conceptual framework of institutions and property rights. The section defines the concepts of institutions, property rights, and land tenure; reviews the historical origins and importance of property rights to land; discusses the social, political and economic aspects of land tenure; and summarizes and discusses the theories of institutional change proposed by Demsetz (1967) and AJR (2005b). 
Section III provides a historical background of Bulgarian land tenure institutions existing prior to $17^{\text {th }}$ century and a slightly more detailed discussion on the developments in those institutions in the period between $17^{\text {th }}$ and $19^{\text {th }}$ century. The goal of this section is to provide historical background which will be used and referred to in the following sections. Section IV critically evaluates the process of transition to the land tenure institutions introduced in 1858, describes those institutions, and identifies the major factors which influenced their evolution. Section V analyzes the mechanisms by which the 1878 transition to the post-liberation regime was accomplished and discusses the evolution of the post-liberation land tenure institutions. In parallel to their historical narratives, sections IV and V critically evaluate the evidence as it relates to the two theories of institutional change. Section VI concludes. 


\section{Literature Review}

\section{1 Defining Institutions}

To understand the way institutions are studied in the NIE, it is useful to start with the two-part definition proposed by Davis and North (1971). The first part of that definition concerns what Davis and North call the institutional environment which deals with the background conditions that shape human behaviour and exchange, and the second concerns the institutional arrangements which refer to the mechanisms of governance.

\section{1.1 The Institutional Environment}

Davis and North $(1971,5)$ define the institutional environment as "the set of fundamental political, social, and legal ground rules that establishes the basis for production, exchange and distribution." These ground rules are precisely what North later elaborates on and defines as institutions (1990, 3-4):

Institutions are the rules of the game in a society, or more formally, are the humanly devised constraints that shape human interaction. In consequence they structure incentives in human exchange, whether political, social, or economic... Institutions reduce uncertainty by providing a structure to everyday life... In the jargon of the economist, institutions define and limit the set of choices of individuals... Institutions include any form of constraint that human beings devise to shape human interaction... Institutions may be created, as was the United States Constitution; or they may simply evolve over time, as does the common law... Institutional constraints include both what individuals are prohibited from doing and, sometimes, under what conditions some individuals are permitted to undertake certain activities. As defined here, they therefore are the framework within which human interaction takes place... [T] he rules and informal codes are sometimes violated and punishment is enacted. Therefore, an essential part of the functioning of institutions is the costliness of ascertaining violations and the severity of punishment. 
The key word in North's analysis of institutions is constraints - institutions are composed of constraints that are devised by and imposed upon individuals with the purpose of achieving a desired structure of interaction or pattern of behaviour. Furthermore, it is useful to distinguish between the three fundamental elements that comprise institutions: (1) formal or written rules created by human beings such as constitutions, statute law, common law, regulations, and laws governing contracts these can be created by governments as well as within firms and other organizations; (2) informal or unwritten rules such as culture, norms of behaviour and self imposed codes of conduct, customs, and values - these are generated from socially transmitted information and imposed by people upon themselves in order to structure their relationships with each other; and (3) the enforcement mechanisms of both formal and informal rules.

The importance of the third element, the enforcement mechanisms, is crucial institutions are deemed to be ineffective when they are not enforced. Enforcement mechanisms are viewed as an integral part of the institutional environment of a society. It is often assumed that once created, institutions are necessarily enforced but in reality, enforcement mechanisms can function fully, marginally, or not function at all. According to Yeager $(1998,10)$, they can be "the single most important element in explaining differences in economic performance."

North emphasizes the major role of institutions in a society as "to reduce uncertainty by establishing a stable (but not necessarily efficient) structure to human interaction" and 
points out that both formal and informal institutions are evolving and changing, thereby continually altering the choices available to us $(1990,6)$. For North, the change in institutions occurs incrementally since it is a consequence of the imbeddedness of informal constraints in societies. While the change in formal rules might occur as fast as overnight, "informal constraints embodied in customs, traditions, and codes of conduct are much more impervious to deliberate policies. These cultural constraints not only connect the past with the present and future, but provide us with a key to explaining the path of historical change" $(1990,6)$.

Furthermore, North (1990) and Williamson (1994) strongly emphasize the need to differentiate institutions from organizations in order to better understand and assess the complex interactions between the two as well as the significance of each. While institutions are the 'rules of the game', organizations are the 'players of the game' organizations are groups of individuals bound by a common purpose to achieve objectives (North 1990, 5). These players can be political bodies (e.g., political parties, a city council, and a regulatory agency); economic bodies (e.g., firms, trade unions, family farms, and cooperatives); social bodies (e.g., churches, clubs, and associations); and educational bodies (e.g., schools, universities, and vocational training centres).

In emphasizing the relationship between institutions and organizations, North draws attention to the role of institutions as the underlying rules of the game on one hand, and the role of organizations as agents of institutional change, on the other. Moreover, he points to the need for "separating the analysis of the underlying rules from the strategy of 
the players" as an absolute prerequisite to building a theory of institutions (1990, pp. 5).

It is stressed that:

Like institutions, organizations provide a structure to human interaction. Indeed when we examine the costs that arise as a consequence of the institutional framework we see they are a result not only of that framework, but also of the organizations that have developed in consequence of that framework. Conceptually, what must be clearly differentiated are the rules from the players. The purpose of the rules is to define the way the game is played. But the objective of the team within that set of rules is to win the game - by a combination of skills, strategy and coordination; by fair means and sometimes by foul means. Modeling the strategies and the skills of the team as it develops is a separate process from modeling the creation, evolution, and consequences of the rules

\section{1.2 Institutional Arrangements}

As noted above, North and Davis $(1971,6)$ distinguish the institutional environment from institutional arrangements. An institutional arrangement is defined as "an arrangement between economic units that governs the ways in which these units can cooperate and/or compete. It can provide a structure within which its members can cooperate...or it can provide a mechanism that can affect a change in laws or property rights."

Institutional arrangements are precisely what Williamson $(1985,1994)$ refers to as the institutions of governance (e.g. business firms, public bureaucracies, non-profit organizations) which have been the concern and study of transaction cost economics and which represent Williamson's 'bottom-up approach to economic organization' (1994, 174). This approach represents the clear distinction between the institutions and organizations or modes of organizations of a society such as markets, hybrids, hierarchies, and public bureaus. Adding individuals as the third level, Williamson 
demonstrates the relationship between the institutional environment, governance structures and the individual.

Williamson warns against assigning too much weight to the institutional environment and too little to the institutions of governance. He suggests that all levels are of equal importance in the analysis of institutions and that one should not overemphasize the role of the institutional environment at the expense of institutional arrangements (the institutions of governance). For example, court ordering would be no more important than private ordering and de facto governance would be no less important than de jure constitutional arrangements.

\section{2 Land Tenure as a Property Rights Institution}

\section{2.1 Historical Origins and Importance of Property Rights to Land}

In development studies, property rights to land can be defined as the "social conventions that regulate the distribution of the benefits that accrue from specific uses of a certain piece of land" (Deininger 2003, xxii). Associated with the general desire for order, property rights to land are historically viewed as a central part of human existence, since, in some form, they have been defined and institutionally administered in the vast majority of cultures from primitive to modern times (Pipes 1999, 116). ${ }^{15}$ For instance, huntergatherer and tribal societies designed institutions that clarified who had rights to land and hunting territories (Anderson 1996, 6; Deininger and Feder 1998; Pipes 1999, 12). The shift to an agrarian lifestyle centered on territory and soil cultivation is believed to have

\footnotetext{
${ }^{15}$ Referring to a number of anthropological studies, Pipes notes that there is no record of a primitive culture or society that has not, in one way or another, defined, administered, and enforced property rights.
} 
increased the importance of property rights since improvements in agricultural land required the investment of individuals' time and effort. Population growth enhanced the scarcity of land which brought fierce competition for land as the most fundamental natural resource - strong assurance that no other party, including the state, could expropriate the return on investment or confiscate the created wealth would be necessary for individuals to continue investing in land (Anderson and Huggins 2003, 7).

Issued in 1215, the Great Charter of England, known as the Magna Carta, was the first and most important legal document which defined and provided for the protection and security of individual property rights. The Magna Carta was one of the inspirations for the U.S. Constitution and has greatly influenced almost all common law states. Individual property rights to land were entrenched in the laws of most Western European Empires; and with the emergence and rise of capitalism, Western European states appear to have been determined to recognize, clearly define, secure, protect, and enforce private ownership and other rights to land by the rule of law.

By contrast, following Marx's argument that private property is naturally illegitimate and, as an exclusive product of capitalism, is the primary source of social inequality, a number of states, at one point comprising one third of the world's population, abolished private property by expropriating it and introducing instead a state and collective ownership and regulation of property rights. Other societies, primarily African, have preferred to manage and regulate land relations according to traditional or customary rules. 
Historical experience suggests that different property rights arrangements are associated with economic and social outcomes varying from disastrous to efficient. Coase (1937, 1960) was among the first to point that economically efficient resource allocation requires a clear definition and assignment of property rights. De Alessi's (2003) collection of empirical evidence from around the world demonstrates that well defined and enforced individual property rights lead to increased incomes and promote efficient use of resources by encouraging investment in their maintenance, improvement, and conservation. Many scholars view individual property rights as the fundamental source of prosperity and argue that the establishment and enforcement of clear and secure individual property rights in the Western world has played a key role in its rise (De Soto 2000; Libecap 2003; North 1981; North and Thomas 1973; North and Weingast 1989). In support of this argument, econometric evidence suggests that individual property rights have been the primary determinants of modern economic growth and that, in fact, clear definition and strong enforcement of property rights is an absolutely necessary condition for achieving economic success. ${ }^{16}$

On the other hand, the economic stagnation and dramatic failure of countries which in the name of social equality adopted state and collective ownership and rights to land, labor, and capital, is most often and to a great extent associated with their failure to recognize the significance of private ownership and rights as the primary incentives for productivity

\footnotetext{
${ }^{16}$ Some of the most significant evidence is provided by Acemoglu, Johnson, and Robinson (2001, 2002a, 2002b, 2005a); Aron (2000); Clague et al. (1997); Knack and Keefer (1995); Rodrik (1996, 1999a, 1999b); Rodrik, Subramanian and Trebbi (2004).
} 
and growth. ${ }^{17}$ Moreover, the rich literature on the experience of the countries in transition from a socialist planned to a capitalist market economy suggests that former socialist countries which managed to establish clearly defined and enforced property rights along with the other institutions of capitalism have demonstrated impressive economic progress. By contrast, countries which failed to do so seem to lag significantly behind. ${ }^{18}$ Furthermore, a number of serious development issues (the major one being poverty), which are believed to arise due to various suboptimal arrangements of property rights to land, are evident in Latin America, Africa, parts of Asia, and Eastern Europe (Deininger 2003, Deininger and Binswanger 1999, Feder and Feeney 1991).

What is known with certainty is that, in one form or another, property rights to land have always been an integral part of human existence as people of various nations devoted considerable time and effort in developing institutions necessary to administer and regulate relations to land. As North $(1990,6)$ suggests, these institutions have historically provided a relatively stable, although not necessarily efficient structure to human interaction. Therefore, one can comfortably assume that the establishment of some form of property rights to land is essential for the economic and social well-being of both individuals and societies. To be sure, there are yet questions that remain unanswered: what are the primary drivers of the evolution of property rights over time and what are the optimal arrangements of rights to land from an economic and social perspective? Even more important and challenging to answer is, perhaps, the question posed by $\mathrm{De}$

\footnotetext{
${ }^{17}$ This is not to say that the only problem of the former socialist countries was the collective character of property rights; there are situations in which collective ownership may be superior to private ownership. Rather, it is to draw attention to the incentives and disincentives provided by each.

${ }^{18}$ For a detailed discussion and comparative analysis, see Benham and Benham (1997); Cornia and Popov (2001); Clague et al. (1997); Hoff and Stiglitz (2002); Popov (2000); Svejnar (2002).
} 
Soto $(2000,12)$ - why does copying the property rights arrangements and laws of the West (which seem to work for the West) fail to work in the rest of the world? These questions will be addressed in the subsequent sections of the essay.

\section{2.2 Social and Political-Economic Aspects of Land Tenure}

\section{2.2.1 Defining Land Tenure}

The term 'land tenure' is derived from the Latin expression for 'holding' or 'possessing' and generally refers to the legal terms and conditions on which something is held; or in other words, to the legal rights and obligations of the holder (Bruce 1998).

For the purposes of this research, and cf. Section II.1, land tenure is defined as the institutional arrangement that specifies and regulates the relationship between people and the land on one hand, and the relationship among actors, both as individuals or groups, with respect to the rights to own, use, control, and transfer land, on the other. ${ }^{19}$ Whether formal or informal, the rules of land tenure: (1) constrain and shape the interaction between people and the land, as well as the interaction between different groups of people in relation to the land; (2) determine who can have access to the rights to own, use, control, and transfer land resources; (3) specify and govern the conditions under which access to these rights is granted; (4) create the mechanisms of enforcement to provide for the effectiveness of rules; and, as a result, (5) structure incentives and disincentives for the occurrence of land transactions and development of land markets. Incorporating a complex combination of political, economic, social, cultural, and legal

\footnotetext{
${ }^{19}$ The definition of land tenure is derived using the descriptions provided in the Land Tenure Studies document of the Food and Agriculture Organization of the United Nations and in Daudelin (2005).
} 
factors, land tenure presents a multidimensional character. Consequently, its evolution and development is a multifaceted process dependent on and embedded in the different social and historical context of nations and therefore varies widely across countries.

For simplicity, the many different types of property rights to land are often classified into three major groups: (1) use rights — the rights to use the land for subtractive benefits such as withdrawing resources, growing subsistence crops and grazing while excluding others from using the land; (2) control rights - the rights to make decisions about the particular methods by which the land should be used, managed, and improved; and (3) transfer rights - the rights to reallocate use and control rights, to sell or lease the land, to convey the land to heirs through inheritance (FAO 2002). A more detailed list of the types of property rights is provided in the table below: 
Table I.1 Types of Property Rights to Land

\section{Types of Property Rights to Land}

Use rights (the rights to use the land, usus in Roman Law)

- A right to access the land (enter the domain, e.g. the right to go into a farm).

- A right to subtract benefits (withdrawing resources, growing crops, grazing).

- A right to exclude unauthorized people from using the land.

Rights to derive income from the land (usus fructus in Roman Law)

- A right to appropriate the return from the land (e.g. harvest the fruits, take the product).

Rights to control and transfer land (abusus in Roman Law)

- A right to control how land will be used.

- A right to protection from illegal expropriation of the land.

- A right to transmit the rights to the land to one's successors, (i.e., a right held by descendents to inherit the land).

- A right to alienate all rights to the entire holding (e.g., through sale), or to a portion of the holding (e.g., by subdividing it).

- A right to alienate only a portion of the rights, e.g., through a lease.

- A residuary right to the land, i.e., when partially alienated rights lapse (such as when a lease expires), those rights revert to the person who alienated them.

- A right to enjoy the property rights for an indeterminate length of time, i.e., rights might not terminate at a specific date but can last in perpetuity.

- A duty not to use the land in a way that is harmful to other members of society, (i.e., the right is held by those who do not hold the right to use the land).

- A duty to surrender the rights to the land when they are taken away through a lawful action, (e.g., in a case of insolvency where the right is held by the creditors, or in the case of default on tax payments where the right is held by the state).

Source: (FAO 2002). Slightly modified by the author. 


\section{2.2.2 Interests over Land}

The multiple property rights that constitute a land tenure regime with respect to a piece of land are often considered to be a 'bundle of rights' since they can belong to several different individuals or groups of people. ${ }^{20}$ The multiplicity of rights (especially when poorly defined and enforced) underlies the existence of deep-rooted conflicting interests in society over land, which further complicates the nature of land tenure. These interests are identified by FAO (2002) as follows:

- Overriding interests are in place when a sovereign body on a national or community level has the powers to allocate or reallocate land through expropriation.

- Overlapping interests occur when several parties are allocated different rights to the same parcel of land. For example, one party may have lease rights; another may have a right of way.

- Complementary interests are of concern when different parties share the same interest in the same parcel of land. For example, members of a community share common rights to grazing land.

- Competing interests are in place when different parties express or claim the same interests in the same parcel. For example, when two parties independently claim rights to exclusive use of a parcel of agricultural land.

\footnotetext{
${ }^{20}$ The term "land tenure regime" is used to describe the system of constraints involving both the rules and the mechanisms of their definition and enforcement.
} 
The presence of conflicting interests suggests that a particular structure of property rights to land is the main source of creating opportunities for one individual, or group of individuals, to affect the opportunities of another, and therefore affects the mutual interaction between different individuals or groups of people. In addition, given the role of the state as the creator of rules in the formation of a particular system of property rights or in the shift from one system to another, it is important to consider the interests of ruling governments and other powerful groups or elites. A particular land policy or reform defines certain distributional consequences with respect to the rights to land and thus it will necessarily be to the advantage of some groups of people and to the disadvantage of another.

\section{2.2.3 Land Administration}

Land administration refers to the mechanisms of governance of land tenure and is broadly defined as the set of processes that allow for the operationalizaton of land tenure rules. It includes processes of land registration and titling, cadastre, valuation, and land inventory, as well as the processes of determining, recording and disseminating information about the ownership, value, and use of land when implementing land management policies (FAO 2002).

Land registration and titling is viewed as the most important element of land administration under statutory land tenure of private ownership. Many studies emphasize the economic benefits of land registration and titling. For example, Collier (1983) and Aku (1986) point to the importance of land titling in obtaining commercial or bank loans. 
Salas et al. (1970) argue that land registration has significant impacts on investment and find a positive relationship between household income and land titling. Lanjouw and Levy (2002) report that titling contributes significantly to the increase in the value of a land property. The comprehensive study of Feder et al. (1988) provides strong empirical evidence for the impact of land registration on access to formal credit, as well as on investment, output, and income. Furthermore, the study finds that land registration is closely associated with increase in the number of land transactions and that the rates of return to titling for the society as a whole are high. Similar findings are provided by Alston et al. (1996), Carter and Olinto (1996), and Lopez (1996). In addition, these same studies assert that land registration significantly affects agricultural productivity. On the other hand, research in some African countries indicates little or no impact of land titling on investment in land, land productivity, land improvements or access to credits (Atwood 1990; Migot-Adholla et al. 1991; Place and Hazell 1993).

\section{2.2.4 Access to Land}

Access to land is most often associated with the ability of individuals to obtain and own a parcel of agricultural land. The meaning of the term, however, is not limited to the right of ownership. Access to land also refers to the ability to use, control, and transfer rights to the piece of land under possession. Individuals can have access to land as a consequence of inheritance or as a result of private actions such as purchase, leasing, sharecropping, or encroachment. Access to land can also be provided by governments in accordance with the implementation of land policies and land reforms. 
Among the many issues related to access, the total or partial lack of access to land for those who are willing, and perhaps able to gain from its use, appears to be the most common problems across countries. Demographic and natural factors, combined with social and political dynamics are considered to be the key factors contributing to landlessness (Daudelin 2005). Inadequate access to land, on the other hand, is often related to the process of division of land into units or plots too small for rational exploitation. Access to land is believed to have little or no benefits if the parcel of land to which an individual has access is so small that it can barely provide subsistence and cannot provide incentives for adequate investment. As in the case of early $20^{\text {th }}$ century Bulgaria, division of land into small parcels often results from government policies aiming at egalitarian distribution of land, as well as from the system of partible inheritance. In each case, undersized farms are often viewed as a major source of inefficiency and low productivity (Kopeva and Noev 2001; Lerman 2002).

\section{2.2.5 Security of Tenure}

Security of tenure refers to the degree of certainty that an individual's rights to land will be recognized by the state, public authorities, members of the local community and society as a whole and protected when these rights are challenged for whatever reasons. In its narrowest usage, common among legal professionals, tenure security implies confidence of the landholder in the legal system that neither individuals, nor the state can interfere with her rights of ownership and use of land as well as lack of worry about loss of one's rights in land (Bruce 1998). Therefore, formal institutions of a society such as legal systems administered by central and local governments, farmers' organizations and 
associations along with their enforcement mechanisms represent a key source of security of tenure. On the other hand, informal structures such as customary tenure or some form of communal agreements, and their enforcement mechanisms can also be an important source of tenure security (Deininger and Feder 1998; Lanjouw and Levy 2002).

For economists, in addition to the factor of confidence, tenure security includes the factor of duration of tenure. Since property rights are believed to provide incentives for investment in land, rights have to be awarded for a time frame long enough to recover the cost of an investment (Bruce 1998) and to allow returns or profits from possible investments to accrue (Deininger 2003, Roth and Haase 1998). Therefore, from an economic point of view, a tenure which is too short or too uncertain for most investments would be considered as lacking security. A third element of tenure security is the requirement of full private ownership rights - even if the confidence and duration requirements are in place, a tenure would be considered insecure if the holder cannot freely sell and buy the tenure (Bruce 1998).

Evidence suggests that both formal and informal tenure security significantly affects farmer's investment decisions, incentives for improvement and conservation of the land, and access to credit (Deininger and Feder 1998). Some studies, however, point to the existence of reverse causality — farmers are likely to undertake land investments in order to enhance security of tenure (Otsuka and Place 2001; Sjaastad and Bromley 1997). Insecurity of tenure, on the other hand, can be viewed as "a random probability of loss of future income due to conflicting challenges" (Deininger and Feder 1998). Deininger 
(2003) suggests that insecure land tenure, particularly in developing countries, is an obstacle to realizing benefits such as greater investment incentives, transferability of land, and improved credit market access.

One problem with the concept of tenure security is that it is difficult, if not impossible, to measure since it is not observable - most often tenure security reflects the perception of individuals about the security of their rights (Roth and Haase 1998; FAO 2002). According to Roth and Haase, this perception is formed on the basis of both the existing elements of security in a particular jurisdiction and the expectations of an individual. ${ }^{21}$

\section{2.3 Two Approaches to the Evolution of Property Rights to Land}

This section discusses the two theories of institutional change which will be used to evaluate the evolution of Bulgarian land tenure institutions in the following sections of the essay.

\section{2.3.1 The Efficiency Approach}

In a world of scarcity and change, competition for the right to use resources is inevitable (De Alessi 2003). Most economists take precisely this reality as a starting point to explore property rights to land and develop theories about their evolution. Indeed, the dominant view offered by the new institutional economics literature is that, as the value of a resource increases, the gains from its privatization eventually exceed the costs of defining and enforcing private rights over it and so individual property rights emerge and

\footnotetext{
${ }^{21}$ The studies reviewed by Deininger and Feder (1998) measure security of tenure by the extent of rights possessed by the owner.
} 
develop as the most economically efficient arrangement (Baland and Platteau 1998). Thus determining why value increases explains why private property rights emerge.

The analysis of the question of how a particular land tenure system emerges and evolves is often based on the theoretical framework of property rights provided by Demsetz (1967). Demsetz describes property rights as an instrument of society which derives significance from the fact that they help a man form those expectations which he can reasonably hold in his dealings with others and which are expressed in the laws, customs, and mores of a society. Emphasizing that "property rights convey the right to benefit or harm oneself or others" (p. 347), Demsetz further clarifies that "property rights specify how persons may be benefited and harmed, and, therefore, who must pay whom to modify the actions taken by persons" (p. 347).

Elaborating on the close relationship between property rights and externalities, Demsetz identifies "guiding incentives to achieve a greater internalization of externalities" (p. 348) as the primary allocative function of property rights. ${ }^{22}$ Consequently, viewing property rights as endogenous, he hypothesizes that "property rights arise when it becomes economic for those affected by externalities to internalize benefits and costs" (p. 354).

\footnotetext{
${ }^{22}$ Acknowledging the ambiguity of the concept, Demsetz defines externality as including external costs, external benefits, pecuniary, and non-pecuniary externalities. As he explains, "what converts a harmful or beneficial effect into an externality is that the cost of bringing the effect to bear on the decisions of one or more of the interacting persons is too high to make it worthwhile, and this is what the term shall mean here" (p. 348). Internalizing externalities, on the other hand, is described as "a process, usually a change in property rights, that enables these effects to bear (in greater degree) on all interacting persons" (p. 348).
} 
As rephrased by Demsetz, the thesis states that "...the emergence of new property rights takes place in response to the desires of the interacting persons for adjustment to new benefit-cost possibilities" (p. 350). This implies that property rights emerge spontaneously within society, in response to economic forces. Therefore, the evolution of property rights is an endogenous, bottom-up process that is heavily motivated by economic reasoning, particularly by concerns of achieving economic efficiency. It has to be noted that in the case of Western societies, Demsetz recognizes gradual changes in social mores and in common law precedents as equally important factors contributing to the emergence, changes, and adjustments in property rights. Therefore, it can be concluded that, for Demsetz, property rights operate within a social, legal, and economic paradigm.

In support of this thesis Demsetz presents anthropological evidence related to the Montagnes, the American Indians who inhabited regions around present day Québec, Canada. The evidence suggests that unlike the Indians of the American Southwest, the Montagnes had a well-established system of property rights to land, which, Demsetz argues, emerged as a result of the advent of fur trade. As the value of furs to the Montagnes increased considerably, the scale of hunting activities rose sharply which in turn brought the increased consideration of the externalities related to free hunting. Demsetz concludes that the property rights system began to change precisely in a way that takes account of the economic effects brought by the fur trade. 
Many studies followed and expanded Demsetz's insights to the nature of property rights. Whether in a broader framework (Davis and North 1971; De Alessi 2003; Libecap 2003; North and Thomas 1973, Williamson 1979, 1985), or in a narrower one (Alchian and Demsetz 1973; Anderson and Hill 1975; Anderson and Lueck 1992; Cheung 1971), analyses focus of economic variables as the main factors influencing property rights and suggest that decisions with respect to property rights are determined by considerations of interacting persons for the marginal benefits and costs of activities. In other words, property rights tend to be allocated and reallocated in the direction of efficiency. It has to be noted that while the endogenous nature of property rights and the search for efficiency are emphasized as the main forces behind the evolution of property rights, legal origins, historical accidents, ideology, factor endowments, entrepreneurship (with respect to property rights), the state and political institutions are recognized as important factors influencing the direction of change in property rights arrangements.

Not surprisingly, this generally accepted theory of evolution of property rights is open to criticism. Baland and Platteau (1998) draw attention to two major limitations. The first is a methodological problem concerning an unavoidable selection bias resulting from the fact that we are only able to observe resource systems and societies that have persisted ${ }^{23}$; the second is that the range of the considered evolutionary patterns has been too narrow. ${ }^{24}$ Regarding the latter issue, Baland and Platteau point that "Suboptimal evolutionary

\footnotetext{
${ }^{23}$ Baland and Platteau hypothesize that if the case was such that property rights evolve in a completely haphazard manner, in the long run, only those arrangements that survived as a result of better adaptation would be possible to observe. This, however, may not always be the case - for example, the postliberation land tenure regime of Bulgaria did not persist, yet we are able to observe it.

${ }^{24}$ Here Baland and Platteau consider the overlooked "possibility of degeneration into an open access regime owing to a lack of adaptability of the society concerned" (p. 647).
} 
patterns actually reflect the fact that forces other than efficiency may be at work in human societies" (p. 647) and identify three such possible forces: the role of the state, the influence of cultural and social norms (later defined as social capital), and the distributive consequences of institutional change.

Drawing on a number of examples, Baland and Platteau demonstrate that the influence of the state can lead to the direction of both efficiency and inefficiency and that in many cases state interventions can and have disturbed the evolutionary sequence of property rights. With respect to social capital, they emphasize that evolution depends on the initial stock of social capital — if distrust, defection, shirking, and exploitation are initially prevalent in society, cooperation and collective regulation will be hard to achieve and so it is unlikely that property rights will emerge. As for the third possible force, new institutional arrangements often lead to division of resources which can result in changes in individual status and therefore threaten the existing social balance. Consequently, community decisions may often be biased in favor of the status quo.

Demsetz' efficiency theory of property rights has been embraced by many new institutional economists and long represented the NIE's view of institutions. Therefore, both the theory and the NIE has been often criticized for ignoring, omitting or failing to take political considerations into account in their analysis (Bates 1995; Eggertsson, 1990; Toye 1995). Indeed, the role of the state, its politics, and political institutions has been increasingly considered as a driver of significant importance in the evolution of property rights and the political character of property rights has been emphasized by many 
(Acemoglu, Johnson and Robinson 2005b; Alston, Libecap, and Schneider 1996; Banner 2002; Levmore 2002; Libecap 1989; North 1981, 1990; Sened 1997; Wyman 2005). In fact, AJR, Banner, Libecap and Sened view property rights as determined and created through political processes. Wyman $(2005,125)$ suggests "theoretical and empirical arguments for reorienting prevailing positive theories of the evolution of property rights to reflect the significance of the decision-making rules in the political process by which private property typically is formed."

Another important issue in the context of this research is that Demsetz's theory fails to specify the mechanism(s) by which the transition to the more efficient property rights regime occurs (Banner 2002). Banner points out that one cannot simply assume that property rights emerge spontaneously as a result of actors' realizing their benefits or in response to new cost/benefit considerations; whether produced formally by a government or informally by the members of a community, the production of property rights necessarily requires collective action. Therefore, no transition can be carried out unless a society has some way or mechanism to overcome the obstacles to collective action inherent in the process. In discussing the missing mechanisms of transition, Banner (2002, S359) hypothesizes that "societies reallocate property rights when some exogenous political realignment enables a powerful group to grab a larger share of the pie." Like Baland and Platteau (1998), Banner argues that if property rights evolve or transitions between regimes occur for reasons other than efficiency, then one would expect to see more inefficient institutions. Furthermore, he asserts that the decision to replace one property regime with another is a political decision and that regardless of the 
nature of transition (efficient or inefficient) a political mechanism has to be in place if the transition is to be accomplished. In other words, the Demsetz approach can not answer the question of why many societies, in their past and present, choose to establish institutions that can be described as inefficient or at least unbeneficial for large segment of its members. As Acemoglu (2004) emphasizes, "Empirically, the efficient institutions view cannot help us understand why some societies adopt institutions that were disastrous for economic growth."

\section{2.3.2 The Social Conflict Approach}

AJR (2005b) develop a framework for examining the path of institutional change based on the social conflict view of institutions which holds that (p. 427):

Economic (and political) institutions are not always chosen by the whole society (and not for the benefit of the whole society), but by the groups that control political power at the time (perhaps as a result of conflict with other groups). These groups will choose the economic institutions that maximize their own rents, and the economic institutions that result may not coincide with those that maximize total surplus, wealth, or income.

In other words, the social conflict view maintains that the driving force behind the emergence of institutions and institutional change are the self-interests of the ruler or the groups in political power at a particular time. Therefore, preferences concerning institutions are determined by their distributional consequences or implications for those who are in power. 
AJR expand on the work of North (1981) in which North "abandoned the efficiency view of institutions" enforces property rights (p. 7) and whose ruler(s) were characterized as self-interested and wealth- or utility- maximizing agents (p. 23). As rulers define and assign property rights in their self-interest, one would expect that those property rights will certainly be beneficial for the ruler but not necessarily for the society as a whole. Therefore, the outcome of institutional change can lead in the direction of either efficiency or inefficiency. In fact, North argues that the widespread tendency of the states to produce inefficient property rights is a fundamental aspect to economic history (p. 23).

AJR (2005b, 392) suggest an analytical framework which is schematically represented as follows:

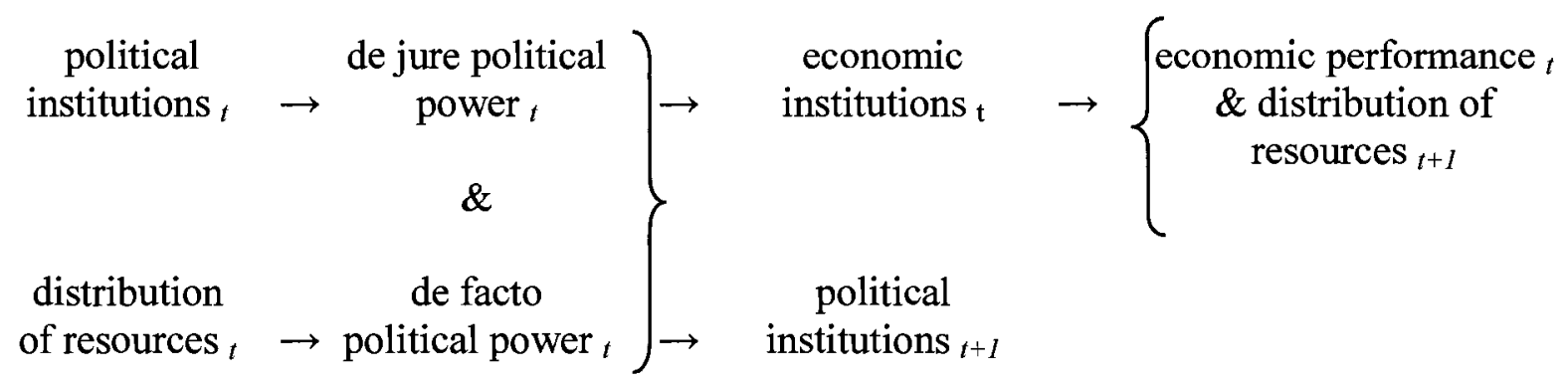

The first two building blocks of this framework are two state variables: the political institutions of a society at a given time $t$ and the distribution of resources in a society at time $t$. Political institutions refer to the form of government (e.g. monarchy, constitutional monarchy, democracy, dictatorship) which determine the constraints on and the

\footnotetext{
${ }^{25}$ This is the expression of North in North $(1990,7)$.
} 
incentives of actors in the political sphere. They also include the extent of constraints on politicians and political elites. Hence, such a relationship is schematically represented in the above framework as:

\section{political institutions $t_{t} \rightarrow \quad$ de jure political power $t$}

Distribution of resources, on the other hand, refers to the economic resources which can provide for the acquisition of de facto political power by a group of people who have no power allocated by political institutions. Economic resources, according to AJR, determine de facto political power because they determine both the ability of the group to use (or misuse) existing political institutions and the option of the group to hire and use force against authorities or other, different groups. Another source of de facto political power noted by AJR would be the ability of such a group to collectively organize revolts, use arms, hire mercenaries, co-opt the military, or use economically costly but largely peaceful protests against authorities to achieve their own goals. This second type of source, however, falls outside the scope of the above framework since, as explained by AJR, "we do not yet have a satisfactory theory of when groups are able to solve their collective action problems" (p. 391). ${ }^{26}$ Therefore, the relationship between distribution of resources and de facto political power is represented schematically as:

distribution of resources $t \quad \rightarrow \quad$ de facto political power $t$

\footnotetext{
${ }^{26}$ AJR seem to ignore the works of Ostrom (1990) and Agrawal and Ostrom (2001).
} 
The distributions of de facto and de jure political powers at time $t$, in turn, affect both the choice of economic institutions at time $t$ and the political institutions at time $t+1$, that is to say, the evolution of future political institutions. Hence, the following relationship:

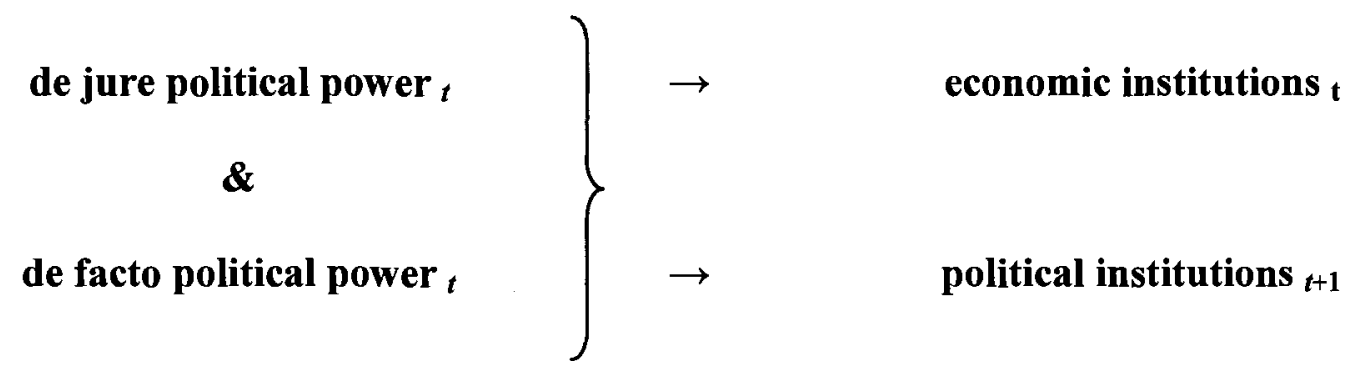

As explained above, de jure (institutional) political power is the power of governing bodies derived from the political institutions of society which determine the constraints on and the incentives of key political actors. De facto political power, on the other hand, is the power of a group of people that is derived from the distribution of resources in society. In other words, it is the political power acquired by group of people by means of opposition, either peaceful or violent, and exercised upon those with de jure political power with the purpose of imposing their wishes on society.

Finally, economic institutions are identified as the determinants of economic performance at time $t$ and the distribution of resources in the future. Studying this relationship falls out of the scope of this study, so for the purposes of the essay, it will be left aside. 
AJR clarify the notions involved in the framework with the example of property rights development in Europe during the Middle Ages. Until the $17^{\text {th }}$ century, the prevailing form of government was monarchy, the political institutions of which provided for a substantial, if not unlimited political power of the ruling monarch. Changes in the English land market and the expansion of Atlantic trade in the $16^{\text {th }}$ and $17^{\text {th }}$ centuries provided the growing economic resources by which landowners and merchants could acquire de facto political power. That political power grew enough to enable the merchants and the gentry to field military forces capable of defeating the king. The change in the distribution of political power resulted in a change in the economic institutions in favour of merchants and landowners whose interests were in securing their property rights.

The framework is further supported by a series of historical examples from across the world, including the transformation from feudal labor market institutions towards modern notions of a free labor market in Eastern and Western Europe, a comparison of the evolution of financial markets in the United States and Mexico, and a comparison of the regulation of prices in agricultural markets in Africa and Latin America.

AJR view political institutions, the distribution of political power (both de jure and de facto), and economic institutions as endogenous elements since they are determined as collective choices of society despite potential disagreements among various groups. The persistence of the behaviour of the system is explained by the durability of political institutions as well as the extent to which a particular group is rich relative to others. Nevertheless, "shocks" such as changes in technologies and the international 
environment are emphasized as potential mechanisms modifying the balance of de facto political power and hence, leading to major changes in political institutions.

As mentioned in the introduction to this essay, the applicability of AJR's theoretical framework to other cases remains to be evaluated in the literature. It is obvious, however, that this framework presents a sophisticated process for the evolution of property rights and incorporates many important aspects of society. It accounts for the role of political institutions, economic and social resources as the driving forces behind the acquisition of political power by groups with conflicting interests, and ultimately the determining role of this power over the choice of a particular set of institutions. It can also provide an account for the mechanisms of transition between different property rights regimes as well as explain the existence and persistence of inefficient institutions. In the following sections of this essay the evolution of the land tenure institutions of Bulgaria will be used to critically evaluate the relevance of the theories of Demsetz and AJR. 


\section{Historical Background}

This section provides a historical background of Bulgarian land tenure institutions existing prior to the $19^{\text {th }}$ century. A brief overview is provided for the period prior to the $17^{\text {th }}$ century and a slightly more extended discussion is provided for the period between the $17^{\text {th }}$ and $19^{\text {th }}$ centuries. Critical evaluation of the evolution of these institutions during the latter period falls outside of the scope of analysis of the essay but the information provided is related to the developments in the $19^{\text {th }}$ century which is the period on which the essay focuses. Nevertheless, to the extent that the evidence presented allows, it will briefly be related to the two theoretical frameworks discussed in Section II.

\section{1 The Ancient and Medieval Periods (681-1393)}

Bulgaria is located in South Central/South East Europe, in the heart of the Balkan Peninsula. The country borders on Romania to the north, the Black Sea to the east, Turkey and Greece to the south, the Former Yugoslav Republic of Macedonia, Serbia, and Montenegro to the west. Organized social life existed on the lands constituting the state of present Bulgaria since the middle Palaeolithic period, from c. 100,000 to 40,000 BC (Crampton 1997, 1). Following the Thracians, the first known civilization to dominate the territory of the country, these lands were successively occupied by the Greeks, Persians, Macedonians, and Romans.

From third century $\mathrm{BC}$ until fourth century $\mathrm{AD}$ the region became part of the Byzantine Empire so the lands were governed by the strict Roman rule, which provided a degree of 
unity and stability never enjoyed before or since in the region (Crampton 1997, 4). Taking advantage of the decline in Roman power, however, pagan Slavonic tribes successfully invaded and settled in the region in the period between fifth and seventh century. ${ }^{27}$ The predominantly agricultural Slavs did not recognize private property and based their relationships on the zadruga (MacDermott 1962, 15; Tsonev 1948, 7). Rooted in the patriarchal tradition of the Slavs, zadruga was a form of extended household organization, typically composed of a few biologically related families which commonly owned and managed their land, labour, and means of subsistence (Todorova 2002, 123; Tsonev 1948,7$).{ }^{28}$ Becoming a common feature of all Balkan nations, in many regions of Bulgaria the practice of zadruga survived up until the beginning of the $19^{\text {th }}$ century. In the seventh century, the Proto-Bulgars ${ }^{29}$ invaded the region and allied with the Slavs to create a Slavo-Bulgar State in 681. This state is known as the first Bulgarian state, which later established itself as the first recognized Slavic state in the world (Cholpanov 1993, 7).

The geographical position of the Bulgarian state was on the crossroads between the East and the West, the North and the South, at the junction of trade routes in close proximity to the straits of Bosphorus and Dardanelles (Hellespont) and connecting the continents of Europe and Asia. Such a position was strategic but also unfavourable as it exposed the state to threats from nations coming from the South, the North-east and the North-west to

\footnotetext{
${ }^{27}$ The Slavs were only loosely knit into tribes; they lacked a single permanent leader and took decisions by popular assemblies. Temporary leaders might be elected in time of war or danger but, in general, anarchy would prevail in their tribal organization (MacDermott 1962, 16).

${ }^{28}$ The head of zadruga was usually its oldest male member.

${ }^{29}$ The Proto-Bulgars were a tribe which originated in Central Asia, in the region between the Urals and the Volga and were comprised of various ethnicities of Turkic origin. They were a nomadic, cattle-rearing people, well-disciplined, skilled in military arts and led by an autocratic ruler, who was at the same time their chief priest (MacDermott 1962, 16).
} 
compete for land and influence in the region (Cholpanov 1993, 5-6). After a number of invasions, border expansions and contractions, the first Bulgarian Empire was established in 896; it was based on the first Slavo-Bulgar state and expanded substantially until 927.

Private property along with tribal aristocracy emerged in the eight century. Increased Byzantine and Slavic cultural influence on Bulgarians followed the acceptance of Orthodox Christianity and of the Slavic alphabet at the end of the ninth century. ${ }^{30}$ As a result of weakening in the central authority of the state, there was a steady increase in the economic and social power of the landowner in the tenth century. The Church, in particular, was a landowner with extensive property (Crampton 1997, 18). In 1018, the country fell under the rule of the Byzantine Empire, lost its autonomy for a century and a half, and was subject to hellenization. ${ }^{31}$

During the eleventh and twelfth centuries (1018-1185), when Bulgaria was ruled by the Byzantine Empire, the pronoia, a land-holding form where the holders of land had the right to its produce but could not pass it on by inheritance, was in effect (Crampton 1997, 23). The decline of the Byzantine Empire and accompanying increasing taxation levied by the imperial government in order to feed its army sparked a revolt led by two influential landowners. The revolt was successful in regaining independence and led to the establishment of the Second Bulgarian Empire, which lasted for two centuries (1185-

\footnotetext{
${ }^{30}$ Bulgaria is known as the cradle of Slavonic written culture. It was from Bulgaria that the Russians obtained their alphabet and church books when accepting Christianity in 988 (MacDeromott 1962, 17). ${ }^{31}$ According to MacDermott $(1962,20)$, Bulgarian clergy, schools and language were replaced by Greek and Bulgarian literary documents were deliberately destroyed. Bulgarian scholars consider this period as the first "lost" period in Bulgarian history as it is believed that "the Byzantine rule caused a chasm in Bulgaria's development and reversed many of the gains made in the previous three centuries" (Dimitrov 2001, 3).
} 
1393). This period is, again, characterized by political instability due to internal and external political strife, expanding territory and power along with internal disorder and social chaos (Curtis 1993, 7). The second mediaeval Bulgarian state fell to the Ottoman Empire, which managed to occupy all Bulgarian territory by the end of the fourteenth century. In the five hundred years after the Ottoman conquest, Bulgaria was to become a colony of the Ottoman Empire and the Bulgarian state ceased to exist until it was reestablished in $1908 .{ }^{32}$ And therefore, what happened in Bulgaria would be heavily influenced by events in the faraway Ottoman state.

From the above brief historical overview, it can be inferred that the need to establish well defined and secure borders was a major problem facing not only the very first Bulgarian state but all subsequent states. This problem could not be resolved; in fact, as Crampton $(1997,10)$ notes, the problem became a permanent and persistent feature of all mediaeval, as well as modern Bulgarian states. Given the circumstances of never ending expansions and contractions of the state, shifting power from one group of society to another, the long centuries of warfare, political and social instability, one could hardly expect the development of any stable form of property rights structures in mediaeval Bulgaria. A more detailed evaluation of this period would perhaps provide strong evidence in favour of the social conflict theory of AJR.

\footnotetext{
${ }^{32}$ The official year of independence from Ottoman rule is 1878 when part of Bulgaria was accepted as a principality and another part, Rumelia, remained under Turkish governance. The modern Bulgarian state, including Rumelia, was established in 1908.
} 


\section{2 Ottoman Rule and the Classical Ottoman Land Tenure Timar: 1393-1600}

The Ottoman Empire was a theocratic monarchy where the head of state, the Sultan, was also caliph (the representative of God on Earth). Most of the imperial administration was conducted on a religious basis and the Christian population of the conquered lands of the empire were never given equality of status with Muslims. ${ }^{33}$ As a result of the conquest, the apparatus of the medieval Bulgarian Empire was completely destroyed. This inevitably led to the destruction of most economic, political, and social institutions of Bulgaria - and especially those above the village or communal level - which were gradually assimilated into the centralized Ottoman state system (Crampton 1983, 1; Curtis 1993, 8; Khristov 1973). ${ }^{34}$

There is no consensus among scholars about what to call the initial Ottoman system of land administration (Lampe 1989, 182). According to Bulgarian, predominantly Marxist, scholarship it was an "immature feudalism." Hungarian and Turkish scholars have argued that it was an "Asian mode of production" whereas Lampe suggests that it was "a command economy on a politico-military pattern not compatible with Marxist categories of class origins." Since it is relevant to this essay, the system is described below but it is left to the reader to judge the extent to which the above theoretical constructs reflect its nature. In any case, at the time of the conquest, Bulgaria was on the way to mature,

\footnotetext{
${ }^{33}$ The Christian population of the Empire was discriminated against in a variety of ways: they were subject to higher taxation, were not allowed to carry arms, could not practice certain trades, could not build houses higher than those of Moslems, and above all, their customs and laws were always inferior to Muslim law (Crampton 1997, 30-31, Khristov 1974, MacDermott 1962, 26).

${ }^{34}$ Bulgarian national traditions continued in rural areas. The Bulgarian church was recognized as a separate patriarchate although under complete control of the Byzantine Patriarchate in Constantinople, which in turn was under the complete control of the Sultan (Curtis, 1993, 8-9). Khristov argues that many local communes and parishes survived along with churches, small schools, and monasteries which would provide the basis for the survival and continuation of Bulgarian language, culture and traditions.
} 
Byzantine type feudalism (Tsankova-Petkova 1964, 6-19, Tsonev 1948) which was quickly reversed by the Ottomans (Dimitrov 2001, 4). ${ }^{35}$ Nobility, being a landholding class and, therefore, a potential source of resistance, was crushed by the Ottomans (Curtis 1993, 9).

As caliph, the Sultan was the only person who was granted the right to legal ownership of land. Therefore, formally, all imperial land belonged to the Sultan; those who worked the land were regarded as belonging to him as well. The reason for this arrangement, according to Inalcik (1969), was that

The economic system of the Ottoman Empire and its basic economic principles derived from a traditional view of state and society which had prevailed since antiquity in the empires of the Near East... In the Muslim state, as in earlier states, all classes of society and all sources of wealth were regarded as obliged to preserve and promote the power of the ruler. Hence all political and social institutions and all types of economic activity were regulated by the state in order to achieve this goal.

It was in harmony with this tradition that the Sultan was regarded as the sole owner of the land and its labourers (Inalcik 1972, 338).

In practice, land was categorized into (1) state land, mirî - crown-land which belonged to the state and comprised all rural agricultural land; (2) private small property or freehold, mülk; and (3) religious property, vaklf whose status was subject to revision at the Sultan's discretion (Adanir 1989, 134-136; Inalcik 1973, 109; MacDermott 1962, 26).

\footnotetext{
${ }^{35}$ MacDermott $(1962,23)$ goes further to argue that, at the time of the conquest, feudalism in both Byzantium and Bulgaria was already in decay and its downfall inevitable in the natural course of events. It is speculated that Bulgaria would perhaps have followed the same line of development as in Western Europe where the growth of towns and trade was ushering in a new era of social and economic development. Lampe $(1989,179-181)$, however, suggests evidence to the contrary and argues that, by 1500 , there was a significant gap between the Balkan and Western European economies.
} 
It is known that a few military chiefs (generals of special status due to their outstanding records) were granted hereditary ownership rights to large estates (gazi mülk) which would generally be converted into religious endowments, vakıf (Adanir 1989, 134, MacDermott 1962,27). Christian monastic property would also fall under a status similar to that of vakıf. Settled villagers, and both Muslim and Christian peasantry engaged in arable farming, were referred to as reaya peasants, and were the taxpaying subjects of the Sultan. ${ }^{36}$ In the villages there existed also a large pastoral population engaged in stockraising - this group was mobile, unattached to the soil, and obligated to pay money rent instead of the usual tithes paid by the reaya peasants (Adanir 1989, 134-135). It is important to emphasize that, no possession or ownership of any of the above categories of land could be established without the legalizing power of the state because it was the state which had the dominium eminens ${ }^{37}$ of all lands (Inalcik 1994, 105). Titles to land were carefully recorded and strictly checked by a surveyor during periodic land surveys; after which a special diploma of the Sultan in power was issued.

The classical Ottoman land tenure regime, known under the name of timar, concerned the use of agricultural land which was under the status of state land, mirî. Introduced in the fourteenth and perfected in the second half of the fifteenth century, the timar regime was

\footnotetext{
${ }^{36}$ Reaya is a general term describing the group of ordinary subjects of the empire - producers and taxpayers comprised of three strictly regulated hierarchies of classes, namely, the tillers of the soil, the merchants, and the craftsmen (Inalcik 1969). The other major group of the populace included those who represented the ruler's authority - administrators, troops, and men of religion who were not concerned with production and were not subject to any taxation. The terms reaya and reaya peasants will be used here interchangeably to refer to the peasants working the land or engaged in arable farming.

${ }^{37}$ Following Islamic tradition, the Ottomans recognized conquest and reclamation as the two underlying principles which established proprietorship in land. As Inalcik explains, "Conquest gave dominium eminens on all lands to the community of the conquerors, the Muslims as a whole, or, more precisely, to the state as its embodiment. The state, then, was the only legitimate authority establishing property rights on land under certain conditions, the most important of which was reclamation (p. 104).
} 
prevalent until approximately the end of the sixteenth century (Adanir 1989, 135). State land was divided into timars, a term referring to pieces of land, granted by the Sultan, under usufruct (cf. Table I.1 usus fructis) to mostly military or cavalry officers (sipahi), who would extract revenue and collect taxes for the state from peasants legally bound to that land. ${ }^{38}$ Both the obligations of the sipahi landlord and the rights and privileges of the reaya peasants (both Christian and Muslim) were carefully and specifically defined, and strictly controlled by the central government (Stavrianos 2000, 138). Although often treated by sipahis as if it was privately owned, timar land was not meant to be private property (Sowards 2005). As Inalcik (1994, 115) and McGowan $(1981,55)$ emphasize, the sipahis were not landowners. Rather, they were state agents who simply supervised the possession and use of land but were expressly prohibited from possessing and cultivating lands reserved for the reaya peasants and were forbidden to form a private holding from any land in which the reaya had any present or past interest, including village common pasture. The cavalryman landholders would not have ownership or heredity rights and would only take benefit from the grant under the condition of remaining in service to the Ottoman army. ${ }^{39}$ Therefore, when dismissed, they would lose control over the land, peasants, and income. Also, the timars of defaulting sipahis and of those who were deceased and without heirs would be promptly retrieved by special authorized agents of the Ottoman treasury (McGowan 1981, 48).

\footnotetext{
${ }^{38}$ Reaya peasants were only legally bound to timar state land. Properties such as house, barn, shop, vineyard, orchard, garden, and the like were under mülk, or freehold status. Peasants could alienate or destroy such properties at their discretion. Since only mülk or gazi mülk properties could be converted into vakif, such land would not comprise arable land. Vakif land would generally include buildings remaining under the absolute property of their owners (MacDermott 1962, 28). Peasants residing on vakif land were not legally bound to that land.

${ }^{39}$ As explained by Inalcik $(1973,107)$, the system of timar arose out of the need to support a great imperial army. State agricultural revenues were assigned to the troops in place of a salary.
} 
As explained by Lampe and Jackson (1982, 24-25), the terms of timar were as follows:

The sipahi had no claim to the land itself; it remained part of the 87 percent of Ottoman territory in the 1528 census that was state land. His sons could inherit no more than a fraction of his income, not necessarily from the same timar and only if they too served to the Sultan. The father received a small fraction of the land, or better, income grant in return for his personal support and three days of peasant labour a year (native Balkan lords had demanded two or three days of labour a week during the late medieval period). Otherwise, the peasants owned the sipahi no personal services. He collected prescribed amounts of their annual harvest, roughly 10 to 20 percent. He typically used this tithe to maintain the several horses and horseman that his grant obliged him to bring to the summer campaigns. Rather than risk the use of forced labour outside the Sultan's direct control, the grant also directed the sipahi to collect certain money taxes from the peasants. By far the largest of these levies was a head tax for the exemption of all adult, nonMoslem males from military service. Finally, peasants might pass on the right to use their part of the timar holding to their sons. They could obtain an Ottoman document attesting to that right.

Based on data obtained from various provincial legislations, land surveys, and court registers, Adanir (1989, 135-136) describes the rights and obligations of reaya peasants under timar as follows ${ }^{40}$ :

The individual peasant disposed of his house, barn, shop, vineyard, orchard, or vegetable garden as mülk, a term of Islamic law corresponding to dominium plenum in re potestatem of Roman law, that is, as private property with all the rights implied by the terms jus utendi, fruendi et abutendi. By contrast, the agricultural land was "state land" (mirî), only the usufruct of which belonged to the peasant. However, the cultivator held the land in the form of a perpetual lease and could, within the limits of local custom, freely determine the crop pattern, provided he fulfilled his obligations toward the sipahi cavalryman, to whom the state had appropriated a certain amount of the agricultural surplus of an area as compensation for military service.

\footnotetext{
${ }^{40}$ Working their land under relative security and justice, the Christian reaya peasant had the following payment obligations: (1) the tithes of all agricultural produce were to be delivered to the sipahi; (2) a land tax called ispence (in reality the money equivalent of the traditional labour services); (3) a head tax amount (for male adults) fixed by Islamic law (cizye) as an obligation to the state - during the sixteenth century, this tax was in the form of an annual household tax; (4) a tax on small animals (e.g. sheep and pigs) paid to the treasury; (5) extraordinary or irregular taxes (avariz-i divaniyye), levied upon fiscal units consisting of three, five, or ten households each (avariz haneleri). The latter category of payments is characterized as the most significant one in the long run - the payments would be collected on an irregular basis with the purpose of covering military campaign expenses (Adanir 1989, 136).
} 
The mechanisms by which the Sultan was able to exercise strict control on both sipahi and reaya peasants were the standardized timar registers, where detailed information on the population and landholdings of each village, on the income, extent and conditions of tenure of each of thousands of timars were systematically recorded (McGowan 1981, 5255). It was this system of registration and control which established the taxes to be paid by peasants, which allowed the Sultan to determine the revenue-generating capacity of peasants, and which greatly limited the potential of sipahis to exploit peasants or abuse the central Treasury (Boyd 1991). The system, therefore, provided tenure security (cf. Section II.2.2.5) to peasants as their rights and obligations were clearly defined, well monitored, and effectively protected and enforced. Inalcik $(1972,339)$ suggests that:

This direct control was regarded as one of the great principles upon which the state was based. With it in mind the Ottomans abrogated every sort of personal feudal bond and kept under vigilant control, subject to law, every sort of local military and legal authority and everything which might be exacted from the villager. Those to whom the padişah [the Sultan] delegated his authority, primarily the provincial beys and their local lieutenants as well as the judges whose duty it was to oversee and guarantee enforcement of the law, kept each other under control as countervailing forces and stayed in continuous written contract with the central authority. The prime duty of the central government was to protect the subject from abuses of authority by local figures.

In sum, the sixteenth century, during which the Ottomans expanded the classical land tenure system timar, is considered by many as the "golden age" of Ottoman rule in the Balkans. Indeed, in terms of the ideas presented in Section II of this essay, the evidence discussed so far suggests a well defined, monitored, and strictly enforced institutional environment which provided a stable structure in everyday rural life in the empire. It also suggests an institutional arrangement which deliberately, pragmatically, and effectively coordinated and governed the operations of economic units, the interaction between 
people and the land, and the interaction between parties in relation to the land. The multiple rights to land (the "bundle of rights") under timar were well defined in the laws and promptly enforced so that abuses and the rise of conflicting and competing interests of sipahis over land were effectively minimized. ${ }^{41}$ The administration of land under religious central authority proved effective for the operationalizaton of land tenure rules - land was carefully registered and titled, land inventories were performed, and information about the use and ownership of land was effectively disseminated. Being well defined, regulated, and enforced under the strict control of the central Ottoman government, timar provided a much higher degree of access to land, security and stability of tenure, as well as justice, than the land tenure present under the rule of local feudal nobility in Bulgaria before the conquest.

However, timar was an institution developed outside of the native institutional environment of Bulgaria and in a socio-economic-politico-religious context completely foreign to Bulgarian society. The Ottoman institution of land tenure was forcefully imposed on Bulgarian society as a result of Ottomans' conquest and their establishing absolute power in the country. In other words, just like in the case of medieval Serbia (and perhaps other Balkan countries) analyzed by Boyd (1991), institutional structures developed in one context, that of Ottoman society, were carried over to another context, that of Bulgarian society. In this respect, the radical adoption of Ottoman land tenure institutions in $15^{\text {th }}$ and $16^{\text {th }}$ century Bulgaria resulted from a completely exogenous factor

\footnotetext{
${ }^{41} \mathrm{McGowan}$ and Inalcik note that abuses were numerous and there was a fierce competition among sipahis over the increasingly limited number of timars. But as McGowan (p.56) points out, "...the total impression given by the laws, and by the minutes of the veziral council still preserved at Istanbul, is of an admirable degree of order, coordination, and even justice... In a system so hedged about with conditions and control, personal fealty was held to a minimum."
} 
thus making it a case not conforming to the theories of institutional change put forward by either Demsetz or AJR.

Turning back to the Ottomans, the question is, why did they introduce timar in Bulgaria and the rest of the Balkans? Were they in a quest for efficiency gains, for rents, or perhaps for both? It seems that it was neither. First, it should be remembered that state ownership of land was an Islamic rather than Ottoman invention (Inalcik 1994, 103). In Islamic jurisprudence, Inalcik argues, "ownership of land was based in the last analysis on the concept of the conquest and the right of the Islamic community (umma) as God's trustees... In Islamic Law from the Prophet's time, Holy War and conquest (cihad and fath) had been considered the principles which established the absolute control of the Islamic community over the land and the labour of the men who cultivated it."

It is of no surprise then that the Bulgarian nobility was crushed immediately at the time of the conquest; being Christians and non-sipahi they could no longer retain rights to their lands. As the discussion shows, however, the Bulgarian Christian peasant was allowed to continue to freely use and cultivate their land while the conquerors simply assumed the position of "rent" collectors. Inalcik $(1994,104)$ notes that there were practical reasons for the rationale behind state ownership of land: it was necessary to create a central imperial treasury which would support the army, whose mission was to defend and further expand Islamic territory. Examining the reasons for which timar emerged and developed the way it did, Boyd (1991) notes that it was based on monetary, rather than labour obligations because of "the monetary requirements of maintaining the military 
apparatus, in particular the standing army, of which the Janissaries were the original component" and of "the recurrent expenses associated with the large, central administrative bureaucracy." In other words, changes in the organization and perhaps the technology of military activity supporting central authority appear to be major drivers of institutional change during the classical period of the Ottoman Empire. Indeed Inalcik $(1973,107)$ argues that the system of timar arose out of the need to support a great imperial army - unable to pay salary to the troops, the state assigned to them agricultural revenues nstead.

However, underneath these drivers for the development of timar lay another - that of the nature of the Ottoman monetary system combined with the inability of the state to collect taxes in cash. Inalcik $(1973,107)$ reveals that

Shortage of coin was a fundamental problem of near-eastern empires. Gold and - even more important - silver were the basis of the money system, and faced with a scarcity of these metals the state had difficulty in financing its great undertakings and, especially, in maintaining a large standing army. It was impossible under these conditions, for the peasant to pay his principal tax, the tithe, in cash, and so he paid in kind. But the medieval state had practically no means of collecting, and converting into cash, taxes paid in kind, and therefore usually sold these sources of revenue to tax farmers. In this way the state lost income and did not collect the funds necessary to pay military salaries. It therefore became the established practice to assign state agricultural revenues to the troops, who collected them directly, in place of salary.

In other words, scarcity of silver and gold appears to be an important driver for the establishment of timar as the land tenure system of the medieval Ottoman Empire. Under these circumstances, Bulgarian landlords could not possibly become sipahis who could commit to serve in the Ottoman army. Even if they were willing to make such a commitment, the religious system of the Ottomans would not permit their participation in 
subsequent conquests, especially, as McGowan points out, given that there was a fierce competition for timar lands among the Ottoman sipahis. Therefore, the Ottomans preferred to eliminate the class of Bulgarian nobility at the time of the conquest, take land under their absolute control, and establish timar in Bulgaria.

\section{3 The Ottoman Informal Land Tenure System Çiftlik ${ }^{42}$ : 1600-1800}

\section{3.1 Introduction}

Starting in the last quarter of the sixteenth century, the timar system was gradually destroyed and formally abolished in 1831 (Pamuk 1987, 87). What emerged in its place was the quasi-private çiftlik landholding system, which is considered as one of the most complicated and difficult to explain institutional arrangement in Ottoman economic history (Gandev 1962, 8; Lampe and Jackson 1982, 33-34, Milkova 1970, 33). Four important points about çiftlik (discussed below) have to be mentioned upfront. First, the çiftlik system was an informal land tenure regime - it was established by powerful groups but, despite tolerated to great extent, never legally recognized by the Sultan or the State as a land tenure system. Second, it involved de facto private ownership - noble individuals claimed ownership to land based on power derived primarily from their authority to collect taxes. Third, the çiftlik system was definitely not an improvement over timar in terms of efficiency; in fact, it was inefficient and oppressive to the extent that the majority of the peasant population refused to work the land and fled to the mountains. This is in contrast to Demsetz's theory that property rights tend to evolve in the direction of efficiency. As the discussion below shows, however, çiftlik seems to be

\footnotetext{
${ }^{42}$ The word çiftik has several meanings. Originally, it referred to a landholding of size 60 to 150 decares (15 to 37 acres), an amount of land that could be worked with a pair of oxen. It later referred to small, medium or larger timar estates that had been converted to quasi-private property.
} 
better adapted to the new context of the empire than timar was, either because, had it been legalized and fully and formally transformed, it would have been more efficient in the new environment (consistent with Demsetz); or because it was more consistent with the capacity of a class better placed to capture rents by exploiting, within certain limits, the relative weakness of the Sultan and his government (consistent with AJR). And fourth, the çiftlik system was somewhat feudal in nature.

\section{3.2 Causes for the Destruction of Timar}

The destruction of the timar and the rise of the çiftlik system was a direct result of the changes starting in the early 1500 s in the classical military organization of the empire. The following developments in the military and fiscal environment of the Ottoman Empire led to the gradual destruction of timar and opened avenues for the emergence of çiftlik.

On the military side, the invention of firearms brought about a shift in the military technology of the Ottoman army and a major change in the military organization of the empire. While the number of troops equipped with the new and more effective firearms technology continuously increasing, the number of cavalry trained to use the traditional and increasingly obsolescent medieval weapons (such as bow and arrow or sword and shield) was continuously decreasing (Inalcik 1973, 48-49). This shift in military technology greatly affected the financial status of the empire as it raised the military costs of the central government, and, most importantly, the costs of the well-established classical timar land tenure system. 
This military shift imposed enormous fiscal pressures on the empire since, unlike the traditional cavalry; the troops using firearms were employed on a full-time basis and paid a monthly salary or daily wage. Agricultural revenue which, according to Pamuk (2000, 132) met 30-40 percent of the military expenses when the sipahis formed the backbone of the Ottoman army, became increasingly inadequate to meet the rising salary requirements of the troops using firearms. ${ }^{43}$ In response to the resulting budget deficits, in 1585-1586 the state opted to debase its silver currency, akçe, to a great extent. Losing 44 percent of its silver content (one of the largest debasements in the history of the empire), the Ottoman currency entered a period of extreme instability (Pamuk 2000, 122-125).

Chronic inflation, along with financial speculation and soaring interest rates further deepened the financial chaos leading ultimately to revolts by groups with fixed income such as timar holders and wage-paid standing forces. Upper classes, such as commanders and judges, resorted to bribes and abuses in order to maintain their income levels (Inalcik 1972, 348-349). The flurry of bribery and sale of office which followed the inflationary period after 1580s afflicted the empire for generations thereafter (McGowan 1981, 56).

Facing inflationary erosion of revenues on one hand and increased military expenditures on the other, the state increased long-standing taxes, and converted extraordinary taxes into regular ones payable in cash and on an annual basis (Inalcik 1973, 50). Most

\footnotetext{
${ }^{43}$ On the other hand, as mentioned above, there was already a chronic shortage of gold and silver - in his comprehensive analysis of the monetary history of the Ottoman Empire, Pamuk (2000, 40-58) discusses in detail the evidence for both the extent and persistence of the shortages throughout the history of the empire and the specific measures taken by the government in response. One of these measures was periodic and frequent (reaching every five, six or ten years during most of $15^{\text {th }}$ century) debasement of coinage (p. 48).
} 
importantly, the state replaced the system of timar revenue collection with tax farming (iltizam) with which it was guaranteed increased and secure revenue, at least in the short run: tax collection was now farmed out to the highest bidder who paid cash for the privilege and committed himself to paying an annual amount to the treasury (Lampe and Jackson 1982, 37).

The gradual dissolution of the timar system resulted from a combination of factors which rendered timar revenue collection and, therefore, the entire system of timar land tenure increasingly ineffective. First, as the cavalry's contribution to the Ottoman army declined, so did the needs of the Sultan to grant them with timars and rely on them to collect the tithe and other taxes. Second, in addition to the discontinued grants of timars, a large part of the already assigned timar lands were taken back and brought under the direct control of the Treasury which farmed out the right to collect their revenue (Inalcik 1973, 49; McGowan 1981, 58). Third, severe inflation adversely affected the living conditions of the sipahi landholder whose incomes in kind were registered in inflexible cash terms and who was therefore supposed to survive on a fixed income (Sowards 2005, McGowan 1981, 57; Milkova 1970, 39-42). As Inalcik argues, being impoverished to the extent that they were unable to make it to the battlefields of ongoing wars, many sipahis abandoned their timars and started to rob the reaya peasants.

\section{3.3 The Emergence of the Çiftlik Land Holding System}

A crucial aspect of the creation of the çiftik system was the system of tax farming, iltizam. Growing in a haphazard way, iltizam created groups of fiscal entrepreneurs who 
became the locally powerful notables (âyans) of the empire. ${ }^{44}$ The âyans drew large income both from overtaxing the population and withholding revenue from the state, as well as power from their authority to collect taxes. Being relatively free from the supervision of the central authority and in an economy where the primary products of the soil were still the predominant source of wealth, the ayans realized the benefits of private property rights to land — just as Demsetz would predict. Indeed, Pamuk $(1987,9)$ argues that, the ayans "responded to increasing opportunities of commodity production for European markets by carving out large estates for themselves and by escalating the exploitation of the dependent peasantry."

By 1700 , their power had increased to the extent that they were able, as autonomous individuals, to bargain with the central administration as equals and ultimately to create a rural land tenure regime relatively independent of central control and authority (Lampe and Jackson 1982, 37). It was the ayans who mobilized against the system of timar, campaigned for the reform of the land regime, and informally began to claim rights to land ownership. As McGowan $(1981,59)$ notes, it is this campaign that is usually called in the literature the çiftlik-building process since it resulted in the appearance in many places, and especially in the Balkan provinces of the empire (Pamuk 1987, 8-9), of sizeable plantation-like estates, called çiftliks.

\footnotetext{
${ }^{44}$ McGowan $(1981,58)$ argues that part of the timar resources reclaimed by the Treasury found its way into the hands of governors and Ottoman dignitaries of all kinds. But the dignitaries who controlled such revenue and the treasury departments responsible for the reabsorbed timar revenues required "a network of primary, secondary, and tertiary contractors to travel to distant territories and do the real work of collection. Many well placed figures took on responsibilities as primary contractors, then subcontracted the real risks and the real work to others." The locally powerful and influential group of landholders, bankers, merchants, and officials rose precisely from the fiscal entrepreneurs who emerged from the system of tax farming. In the remainder of this section, the term âyans will refer to these locally powerful individuals. Many sipahi would also be part of âyans.
} 
The origin of çiftiks is controversial. The sipahi and âyans bribed the state into legalizing the right to inheritance to a timar as a specific private property and into transforming many timars into civil holdings - çiftliks, free from the threat of confiscation (Hupchick 2002, 131; Katsarkova 2001, 583; Stoianovich 1953; Tsvetkova 1964). Adanir (1989, 147) argues that çiftliks emerged primarily as a result of the âans' increasing interest in new land which was usually some abandoned or unused land classified by Ottomans as mezraa. This argument is supported by Gandev $(1962,36-45)$ who, based on the Bulgarian example, provides the most detailed evidence in relation to the origins of çiftliks in the Balkan provinces of the empire. In addition to being formed by the occupation of abandoned state land, they were also formed by the occupation of empty and unregistered land as well as by the seizure of village land cultivated by its peasants. ${ }^{45}$ Furthermore, Stoianovich $(1976,184)$ argues that a çiftlik enterprise would often start as the pasturage ground of a family or clan that would later claim it as its own private or familial property or it would start as the site of a simple water mill or a network of beehives. The çiftlik was generally the site of a new village, smaller than the traditional village of the highlands. ${ }^{46}$

Whatever their origins, çiftlik formation can be described as the emergence of properties with quasi-private and feudal characteristics and as the development of a typically colonial and social institution which led to the emergence of militant pastoral-agrarian

\footnotetext{
${ }^{45}$ Abandoned state land would usually be land located near a road or waterway; seized village land would be land bordering existing villages; empty or unregistered land would be land which required clearing in order to be cultivated. Such lands would formally be under mirî status. As will be discussed below, the amount of land claimed as çiftiks was relatively small, not more than 20 percent of cultivated Bulgarian lands.

${ }^{46}$ As mentioned above, the central government was no longer able to exercise control over rural life. Local notables and sipahi, possessed arms and extended claims to land by force.
} 
colonialism (Stoianovich 1953). Properties administered by the timar were gradually separated into two distinct categories, the reaya-çiftlik and the hassa-çiftlik. The former was the property over which the peasant had rights to usufruct, whereas the latter form emerged as the private farm of the ayans and sipahi and gradually expanded at the expense of the former form, reaya-çiftlik. Christian peasants were the cultivators of hassa-çiftlik as quasi-serfs or tenant farmers with greatly restricted freedom.

Another change brought about under çiftlik involved the choice of crops. In response to international, particularly European, demand, the agents of the çiftlik regime manifested a preference for the development of cash crops such as cereals, olive oil, cotton, and wine which tended to foster a more labour intensive economy (Stoianovich 1976, 184-185). As a result, the çiftlik system came to be characterized:

...by the coexistence of four complementary forms of labour utilization in the cultivation of land: sharecropping, or the division of crops between the providers of protection and/or capital (or of land and capital) and the providers of labour (or of land, capital and labour) either on a half-and-half basis (izpolitza) or in other proportions; the leasing of land for a one year term, with the lease contract to be paid in advance (kesim); the use of wage labourers (ratai), generally young people from poor families who hired out their labour for six months or for a year and were paid in money or kind; and the use of day or seasonal labourers.

On the positive side, çiftlik formation led to an increase in the total amount of land under cultivation - recall the arguments of Adanir, Gandev, and Stoianovich, discussed above, about the formation of çiftiks on previously unused or abandoned land. Stoianovich argues $(1976,186)$ that such lands were brought into cultivation by promoting the practice of sharecropping. On the negative side, çiftliks inhibited the extent to which a well-developed market for land could be organized — çiftlik owners used unskilled wage 
labour and short-term leases (six months or one year). The absence of long-term leases implied insecurity of tenure (cf. Section II.2.2.5 of the essay), discouraged investment in land in the expectation of future profits and consequently led to a rather slow rise in land values (Stoianovich 1976, 188).

Furthermore, Lampe and Jackson (1982, 34-36) discuss the following features in relation to the çiftlik system: (1) although concentrated in the main grain, cotton, and tobacco growing areas of southern Bulgaria and some parts of northern Bulgaria (as well as Macedonia and northern Greece), çiftliks had a limited profitability and extent; (2) çiftliks accumulated too little capital and used too little wage labour or too few modern practice to make it a transitional institution to commercial grain cultivation and large-scale export; (3) as mentioned in the beginning of this section, their owners were mostly influential âaans who had the military means to protect their holdings ${ }^{47}$; (4) most holdings were so small in size that they could hardly have yielded a large marketable surplus, let alone afforded significant economies of scale ${ }^{48}$; (5) the organization of çiftlik villages was such that it did not promote the rise of commercial agriculture - fields were divided into family strips and tilled with primitive wooden plows and landlords were unwilling to

\footnotetext{
${ }^{47}$ Despite the military means of protection from robbery, plundering, or other acts, the tenure of these landholders was still insecure because it was not recognized by the state. At any time, and as it happened later in the 1800 s, the state could expropriate the land on which they illegally established their estates. ${ }^{48}$ This argument of Lampe and Jackson brings the question of how can individuals whose land does not yield significant marketable surplus sustain a military capability. Recall from the beginning of this section that those who became self-proclaimed landlords were the fiscal entrepreneurs who acquired power and income primarily from their control over the tax-gathering process brought with the system of tax farming and from the exploitation of the dependent peasantry. Refer above to the quotes of Pamuk and McGowan on p. 67.
} 
furnish equipment, consolidate cultivation, introduce crop rotation, or other improved methods. $^{49}$

The overall oppressive environment together with increasing disorder and brigandage following the deterioration of central authority and power led to widespread depopulation in the countryside. The peasants lost interest in treating the land well and in working to further to improve it. Faced with tithe, service obligations, and ruinous levels of taxation often reaching over 80 percent and sometimes exceeding the total of the peasant land's productive value, the seventeenth century peasant fled to urban centers or mountains (Stoianovich 1953). As a result of the decrease in the labour force, by the end of the seventeenth century, great amounts of fertile land remained untilled and a number of lowland villages disappeared.

Indeed, as sources reveal, the spread of çiftliks on Bulgarian lands turned out to be quite limited. Dimitrov (1956) and Berov (1956) suggest evidence that, towards the end of the $18^{\text {th }}$ century which is considered the peak period of çiftlik formation, they covered 5 to 20 percent of cultivated land in different areas in Bulgaria. Furthermore, on average, only about 10 percent of Bulgarian peasants were subject to the obligations brought by the çiftlik land tenure regime. What happened to the rest of the land and the rest of the peasantry? The rest of the land was under the control of the Treasury. A small percentage of Bulgarian peasants remained in the lowland areas, operated the land in the form of

\footnotetext{
${ }^{49}$ According to Lampe and Jackson, the size of most çiftliks was in the range 60 to 120 decares, or 15 to 30 acres. The largest were of several thousands acres but composed of fragmented strips of land belonging to 100-200 villages in western Bulgaria and were held by the most powerful âyans. Furthermore, the very nature of çiftlik formation discussed above would leave consolidation of holdings out of consideration.
} 
small holdings of size 30 to 100 decares ( 8 to 25 acres) and were therefore subject to the tithe and taxation set by the state. The majority of peasants, however, settled in upland and mountainous areas of the country where the soil was much less fertile but the location allowed them to grow crops for subsistence, raise livestock, and, most importantly, hide from tax collectors. In other words, the majority of the population took advantage of the opportunity to abandon the land they worked and thus exit this inefficient and oppressive system of land tenure. The geographical characteristics of Bulgaria provided that opportunity: mountainous and semi-mountainous areas make up about thirty percent of the country's land area. Hence, the arguments of McGowan (1981, 64-66) and Stoianovich (1953) that there was no labour present to work fertile lands of the lowlands.

It should be emphasized that, the çiftlik system was never legally recognized by the Sultan or the state as a private land tenure system (McGowan 1981, 56-60; Pamuk 1987, 9; Stavrianos 2000, 141). Under the Ottoman law, the farm land still belonged to the Sultan and therefore was under mirî or state land status. While widely tolerating the formation of çiftliks, the Ottoman authorities resisted the legalization of property rights to land as it was believed that this would further weaken the power of the Sultan. And it should not be forgotten that, historically, state ownership of land was based on Islamic laws and tradition, which would be difficult, if not impossible, to change. But such an illdefined land tenure structure certainly implied increased insecurity of tenure for both the peasantry and the çiftlik owners. Neither had incentives to improve production techniques, invest in land, or increase production levels; indeed, peasants refused to work 
the land and exited the system. This is perhaps the key to the economically dysfunctional behaviour of self-proclaimed landlords: despite their de facto landownership, they lacked real tenure security; the constant danger of intervention by the state, despite its weakened authority and power, was always a matter of consideration. Indeed, as will be seen in the next section, the state did eventually intervene by taking back the lands and crushing the âyans.

\section{3.4 Discussion of the Theories}

The above discussion shows that the driving force behind the changes in the land tenure institutions in Bulgaria over the $1600-1800$ periods was the change in the military technology and administration of the Ottoman Empire, followed by a financial crisis. As far as Bulgaria is concerned, however, the process was again an exogenous one. Bulgarian society was not in the position to influence the changes in the system; the only choice for her was to adapt to the conditions brought by the central Ottoman government and the new local powers. In the cases of both timar and çiftlik, the land tenure of Bulgaria was embedded into the broader, Ottoman land tenure regime. The dynamics of the Ottomans - whether accommodation to achieve military goals, economic efficiency, or rent-seeking conflict dynamics - were the determinant factors of institutional change in Bulgaria.

Turning to the Ottomans, it can be inferred from the above accounts that the emergence of the çiftlik system seems like an 'attempt' at a Demsetz-style evolution of private property rights: the desire of interacting persons for adjustment to the new benefit-cost 
possibilities brought by the rapidly changing financial and economic environment of the empire and by the economic forces in international markets is quite obvious. However, the behaviour of the actors involved in the process seems more like a rent-seeking than an efficiency-seeking behaviour. As Pamuk $(1987,9)$ argues, the appropriation of surplus by these powerful actors was based on the existing organization of production rather than on transformation of the relations of production. The new benefits realized and exploited by notables came from their ever increasing control over the tax-gathering process through the system of tax farming, "usury[,] and extraction of rent payments from direct producers based on de facto ownership of the land."

Furthermore, whatever the motivation of the actors, çiftlik remained an informal system: the shift or transition to a legally or officially sanctioned, properly designed, defined and enforced system of çiftlik property rights was never achieved. The system spread only to a limited extent, remained mostly illegal, ill-defined, and rather insecure until it was crashed by the state in the mid- $19^{\text {th }}$ century. This brings us to the issue raised by Banner (2002) and discussed in Section II.2.3.1 of the essay - Demsetz's theory does not specify the mechanisms by which a transition to a more efficient property rights regime occurs; it simply assumes that actors' realizing the benefits is sufficient for the transition to occur. Banner points out that any transition can only be carried out if a society has some way or mechanism to overcome the obstacles to collective action inherent in the

\footnotetext{
${ }^{50}$ Moreover, according to the evidence revealed by McGowan $(1981,58)$, the powerful individuals who had access to fiscal records resorted to deliberately obfuscate them, "this being the simplest and most effective means by which the powerful could arrange to have their temporary holdings illegally converted either into something resembling absolute property or into permanent pious estates with themselves as beneficiaries."
} 
process. The failure of çiftlik to evolve and establish itself as a legal property rights system is an excellent example for the argument of Banner.

Although falling largely outside of the scope of this analysis, when it comes to the Ottoman Empire, it is worth mentioning that this process of institutional change seems best explained by Acemoglu, Johnson, and Robinson's (2005b) social conflict framework. The introduction of firearms in the Ottoman military was an external shock which altered the balance of political power in the Ottoman Empire. First, it caused a financial crisis which greatly challenged and weakened de jure political power. Second, it made the cavalry obsolete and therefore its process of revenue collection ineffective. Third, the consequent introduction of tax farming allowed different groups to acquire the economic and military resources that allowed them to gain de facto political power. The resulting combination of de jure and de facto political power, however, created the inefficient çiftlik land tenure institutions. As shown in the analysis, both the state and the âyans used their powers to exploit peasants, expropriate their resources, impose arbitrary or predatory taxation and facilitated widespread corruption. ${ }^{51}$

\footnotetext{
${ }^{51}$ Identifying the precise reasons for which the Ottomans ended up with inefficient land tenure institutions in that period would be a question for further research. But in general, would it have been possible, under these conditions, to shift to a land tenure system more efficient and more effective than timar, which was necessarily destined to dissolve? For example, would it have been possible to undertake a radical reform which would convert the territorially based standing cavalry into a territorially based standing infantry? This would certainly fit into the Islamic and near-eastern imperial tradition of state ownership of land. But McGowan $(1981,57)$ suggests that such a solution was either not contemplated or rejected: " $[t]$ he brilliant leadership which radical reform would have demanded was not found. Instead the grouping leaders of the inflation era dealt in makeshift solutions and improvisations, engendering a multitude of evils." Inalcik $(1973,51)$ also concludes that under the impact of a new Europe, the Ottomans were unable to adapt themselves to changing conditions since "[ $t$ ] hey failed to understand modern economic problems, remaining bound by the traditional formulae of the near-eastern state" and by "the values and outlook of near-eastern culture, sanctified by the şeriat [Sharia]." As mentioned earlier, conquest and reclamation, the two principles through which proprietorship in land was established in the Ottoman state (but which now implied ever increasing military costs) as well as state ownership of land were constraints brought by the Sharia and the near-eastern culture of the Ottoman state. Within these constraints, it seems impossible that
} 


\section{The Evolution of the Late Ottoman Bulgaria Land Tenure: 1839-1878}

\section{1 Introduction}

The turn of the nineteenth century found Bulgaria still under the rule of the Ottoman Empire although the powers of the empire were now steadily declining. In a belated effort to rebuild its administrative and institutional capacity in order to regain its strength, self-sufficiency, and influence in Europe, the Ottoman administration was on the eve of launching a series of reforms. The reforms took place in accordance with the Gülhane decree of 1839 during the period 1839-1876, known as the Tanzimat (reorganization) period, and the goal was to radically reorganize the institutions of the Empire. ${ }^{52}$ An integral part of the Tanzimat reforms was the radical land reform which, initiated immediately with the Gülhane decree of 1839 , overturned the çiftlik system and continued with the Land Code of 1858 , which according to Pamuk $(1987,87)$, was enacted under pressures from European powers.

The Land Law of 1858 brought the following changes to the system: (1) surviving timar estates, çiftliks and all other appropriated land (under mirî or vaklf status) were formally recognized to all intents and purposes as a privately owned property - they could legitimately be operated, bought, sold, rented, mortgaged, inherited, or otherwise used

another solution - that of the introduction of individual property rights to land, at least in this turbulent period, would be contemplated.

${ }^{52}$ Inalcik (1941) argues that, facing the rise and increasing superiority of Western Europe the major goal of the Empire was to westernize (or as Todorova (1976) would say, Europeanize) and therefore Tanzimat aimed at reorganizing its institutions following the European model. The most important aspect of the reforms was, therefore, to improve the living standards of the peasants by making them equal before the law and providing them with broad economic, political, and social rights and freedoms (Inalcik 1992, 3-4). 
and transferred to interested or related parties; (2) such rights were granted not only to the Muslim population, but to Christians as well; (3) producers were granted tax rebates for longer periods with the purpose of boosting the cultivation of cash crops; (4) foreigners were allowed to buy and own agricultural land as private property in the Ottoman Empire; (5) the rights of local sipahi landholders and notables to collect agricultural taxes were eliminated — tax collectors were now agents appointed by the central government, most often the local, native chorbadzhii ${ }^{53}$ (Adanir 1989, 150; Lampe and Jackson 1982, 146; Milkova 1970, 40; Stoianovich 1976).

\section{2 Description of the 1839-1878 Land Tenure Regime}

To achieve the goals of Tanzimat, it was necessary for the government to eliminate all de facto ownership of land, to reduce or eliminate the power of the ayans and thus regain full control of the agrarian economy. In the early $1800 \mathrm{~s}$, which is before the official introduction of Tanzimat, the government under the reigning Sultan Mahmud II started to reassert claims to the land and to take control over collection of agricultural surplus (Pamuk 1987, 86-87; Quataert 1994, 854). This brought a shift in the balance of power between the state and the ayans in favour of the former. The government of Sultan Mahmud II attacked the notables in various ways ${ }^{54}$ and, between 1831 and 1837, moved swiftly to destroy the fiscal and economic basis of this alternate source of power. As Quataert notes, the campaigns of the Sultan against the ayans were a major achievement

\footnotetext{
${ }^{53}$ Chorbadzhia (pl. chorbadzhii) is the name given to richer and older town or village landholders who had performed some administrative duties for Ottoman authorities since $17^{\text {th }}$ century.

${ }^{54}$ Quataert $(1994,857)$ discusses examples such as breaking the fiscal monopoly of tax collectors and administrators by designating outsiders to their posts; using the army to attack notables, massive displacement of sipahis which resulted in their loss of revenue from tax collection, and others. Pamuk also points to massive confiscation of lands from tribal or other landlords.
} 
of the state in the beginning of the century because they assured that local powers would not have de jure control of the land.

Tanzimat reforms in general and the land reform in particular, however, proceeded rather slowly. Although the Gülhane decree of 1839 granted Christian and other peasants legal rights to former timar lands; it was only between 1858 and 1867 that the new legal framework for land tenure was introduced. Returning to Land Law of 1858, it has to be emphasized that, the law actually stated that the real owner of state land, mirî, is the Sultan or the State Treasury and therefore, state land is not a mülk, or private land property (Turkish Sources for the History of Bulgaria I, 111). Such an assertion was certainly in line with the old tradition of having the Sultan as the sole real owner of land but for the peasants it implied lack of full ownership of land. Although failing to formally recognize full ownership to land rights, and therefore creating some confusion with respect to the degree of security of tenure, the law stated explicitly, however, that as the kiract or renter of state land, its holder is entitled to use, control, and transfer rights, including the rights to sell it in the future. Furthermore, a decree published in the official state issued Bulgarian newspaper Dunav of May 17, 1867 reassured its readers that the land held by an individual is fully recognized as his or her private property.

In other words, in mid- $19^{\text {th }}$ century, notwithstanding some legal obscurities, agricultural land in Bulgaria had the status of private property, held and controlled by its owner, regardless of their ethnicity or religious affiliation. Through the Land Law of 1858 the Christian population of the empire gained access to rights in land which were previously 
not available to them. Peasants, who constituted the large majority of the Bulgarian population, were increasingly motivated to buy land so that in the course of reforms the proportion of Bulgarian landowners in the Danubian Province exceeded that of the Ottoman Turks (Draganova 2005, 88). ${ }^{55}$ Substantial amount of çiftlik land was effectively transferred from Turkish officials to Bulgarian peasants and the already limited number of çiftliks on Bulgarian territory and their size further decreased following their sale to Bulgarian cultivators. ${ }^{56}$ In addition to peasants entering the market to buy fragments of çiftlik land, they were given the option to resettle on unused state land to which they were granted property rights (Palairet 1997, 46; Todorov and Tsonev 1981, 182).

On the other hand, the reforms placed increased fiscal demands upon cultivators. In return for the right to own private land, peasants were required to pay 15 instead of 10

\footnotetext{
${ }^{55}$ As part of the Tanzimat reforms, the Ottoman Empire was organized in 36 administrative units or provinces according to their geographical, demographic, economic, and other characteristics. The application of Tanzimat reforms, however, was slow and uneven and did not simultaneously affect all provinces. The region of Northern Bulgaria together with Sofia and its counties (essentially more than half of present Bulgarian territory) was established as a main administrative unit under the name Danubian Province (Tuna Vilayeti). It was precisely this province that was selected as the first pilot region for carrying out the reforms (Draganova 2005, 25). Furthermore, Draganova $(1980,5,11)$ notes that parallel to the introduction of the new land laws, the Ottoman administration established a register which recorded and described in details the characteristics of the population of the province and their land and other properties. The land registries include information about the size of owned holdings, the number and size of plots a holding is composed of, the value of holdings and plots, and others. It is those registries which Draganova uses to analyze the socio-economic conditions of the Danubian province during Tanzimat.
}

${ }^{56}$ The exact percentage of cultivated area under çiftliks in the course of reforms on Bulgarian territory is unknown. Draganova $(1985,30)$ estimates that it was 20 percent in southwest Bulgaria, 22 percent in northeast Bulgaria, and about 10 percent in Sofia region. Furthermore, Berov $(1979,20)$ estimates the average percentage of total Bulgarian land under çiftlik as being around 21-23 percent. Nevertheless, according to the survey of land holdings performed by the officials of the Preliminary Russian Administration during 1878-1879 the number of çiftliks on the territory of Bulgaria did not exceed 200 and their size was relatively small - almost half of them were less than 15 acres (Khristov 1976, 112). Lampe and Jackson (1982, 135-137) suggest that Turkish çiftlik owners were eager to sell their estates in the face of decreased or lost profit expectations arising from the series of bad harvests during 1850s, the sharp decrease in grain exports and prices following the Crimean War, and, most importantly, from the lost privileges of tax collection. On the other hand, Bulgarian peasants and merchants were motivated to buy land since they could now freely work it and export their produce - a reform decree of 1839 allowed Christians to trade with the outside world. Increasing European demand for Balkan grain exports in the 1860 s and 1870s further increased their profit expectations from the purchase of land. 
percent imperial tithe with the additional five percent to be paid over the subsequent five years. ${ }^{57}$ Overall, it appears that a cultivator would give up 20 to 30 percent of their total farm output to meet his various obligations to the state (Palairet 1997, 47-48). ${ }^{58}$ Palairet notes that this tax rate was considered normal by European standards of the day and Draganova $(1996,86)$ concludes that the tax rates were reasonable, in contrast with the traditional view of them as being exorbitant and oppressive. ${ }^{59}$ The problem was that taxes levied on the Bulgarian population were higher than those in neighbouring Serbia and Montenegro. In addition, most of the total revenue (about 75 percent) collected from agricultural taxes in the Danubian Province was transferred directly to the Treasury in Istanbul and the small part that remained was used to modernize a few large estates (Lampe and Jackson 1982, 150; Palairet 1997, 48). Therefore, Bulgarian agriculture remained largely primitive and the lack of effort on behalf of the government to invest in its mechanization or for any other improvement in the region left people with no hopes for a brighter future. ${ }^{60}$

\footnotetext{
${ }^{57}$ This increase is announced in issue 175 of state gazette Dunav of May 17, 1876 and is emphasized by Draganova in her studies of different regions in Bulgaria. However, as mentioned by Palairet $(1997,47)$ there is a debate with respect to the exact rate of imperial tithe levied on the cultivator. While Khristov (1976, 175-176) and Lampe and Jackson (1982) note that the rate of tithe was increased from 10 to 12.5 percent, Draganova $(1980,5)$ points that such increase affected only the Muslim population.

${ }^{58}$ This includes the tax on crop output, small livestock, rent, certain property and other taxes. The difficulty in coming up with a precise figure arises from the fact that different taxes were levied in different provinces.

${ }^{59}$ Draganova notes that her estimates support the findings of G. Danailov who in an article published in 1896 in the Journal of Bulgarian Economic Association stated that tax rates of the Tanzimat and of the Ottoman Empire in general were not as high as they were often thought or presented in various sources. ${ }^{60}$ Agricultural machinery and mechanized farming were concepts totally foreign to Bulgarian peasants and it seems that they were reluctant to import the machines for lack of knowledge and training about how to operate or repair them. Midhat Pasha created several model estates in the region and imported agricultural machinery for use at those estates. However, as Lampe and Jackson indicate, there were no skilled farmers to operate or repair them; there were no repair facilities either and so their use was greatly limited. Some landowners imported machinery themselves, but they remained idle or of limited use for the same reasons. The conservatism of Bulgarian peasants would also be a reason for their reluctance to use machinery. Breaking up the traditional farming techniques and a transition to mechanized farming would necessarily require government intervention in the form of investment in training and education as well as the promotion of mechanization. Furthermore, it was Midhat Pasha who created the first agricultural savings
} 
The Tanzimat period (1839-1876), on the other hand, is characterized by a remarkable growth in agricultural, particularly cereal, production accompanied by a substantial increase in agricultural exports for Bulgaria and for the Empire in general (Pamuk 1987, 149, Stoianovich 1976). The estimates of Palairet $(1997,58-65)$ and the figures of Lampe and Jackson $(1982,138)$ for Bulgaria show that, with the exception of some periods of recession, agricultural production and export of grains by the late 1860 s more than doubled compared to the late 1840s. It was growing European demand which accounted for the increase in exports; but the response of Bulgarian producers and traders to such demand was only possible through the reform decree of 1839 which removed all vestiges of the Ottoman grain monopoly (Lampe and Jackson 1982, 138; Quataert 1994, 850). Furthermore, in general, there seem to be no doubt that the security of tenure provided by the Land Code of 1858 allowed the increase in production levels and flow of revenues (Quataert 1994, 861)

\section{3 Discussion of the Theories}

It would be hard to follow Demsetz's efficiency approach to institutional change and argue that the emergence of individual property rights to land in mid-19 ${ }^{\text {th }}$ century Bulgaria took place in response to the desires of the interacting persons for adjustment to new benefit-cost possibilities. It is obvious that property rights were produced by the Ottoman government as an integral and critical part of a broader social, political, and

banks network in Bulgaria. However, the banks lacked any state deposits and could not collect large deposits from landholders. Importing machinery would require the availability of credit opportunities and these were basically absent; the banks could only provide small loans. In addition, after paying taxes higher than anywhere else in the empire, the profits left to the peasants of the region may not have been enough to invest in machinery. Or, higher taxes might have been a disincentive to further investment in agriculture (Lampe and Jackson 1982, 149-150). 
economic process of change. The Ottoman state's introduction of private property rights in the $19^{\text {th }}$ century illustrates clearly the point made by the critics of Demsetz's theory (AJR 2005b, Banner 2002, Libecap 1989; North 1981, Sened 1997; Wyman 2005, cf. Section II.2.3.1 of the essay): property rights are determined and created through political processes and whatever the nature of transition, the shift requires a political mechanism to be in place.

However, the introduction of property rights does conform in part to the efficiency theory because it was a direct result of an external shock which altered the costs and benefits brought to the Empire by the existing çiftlik and state-command systems of land administration. The external shock was the rise and ever increasing superiority of Western Europe in an era of flourishing free trade. Under such conditions, the Empire had no choice but to westernize or Europeanize; as Todorva $(1976,106)$ argues, reforms were driven by the recognition of European superiority and the necessity of borrowing new institutions and methods from the West. Tanzimat, therefore, aimed at reorganizing its institutions from scratch to follow closely the European model of development (Inalcik 1941). The most important goal of the reforms was, therefore, to improve the living standards of the peasants and other reaya groups by making them equal before the law and providing them with the broader economic, political, and social rights and freedoms enjoyed by the European nations (Inalcik 1992, 3-4). ${ }^{61}$

\footnotetext{
${ }^{61}$ Inalcik $(1992,3-8)$ argues that the Ottomans were particularly concerned with improving the living conditions of the Christian reaya peasants and with fully integrating them into Ottoman society in order to create a new, 'unified' Ottoman Empire.
} 
More precisely, the çiftlik system had resulted in steadily decreasing agricultural production and, therefore, decreasing agricultural exports; renewed depreciation of Ottoman coinage; decline of processed exports; growing European debt and ultimately steady decline in the strength and self-sufficiency of the central government (Lampe and Jackson 1982, 133). Realizing that property rights to land were the key to increasing agricultural production and exports which in turn would provide the resources to pay for imported European goods and other expenditures, the Ottoman government decided to grant property rights to peasants, both Muslim and Christian. Not surprisingly, the pilot region for a vigorous implementation of reforms was in the Danubian Bulgaria, which had the potential to be a major producer and exporter of agricultural products, particularly of grain.

In other words, the driving motive behind the introduction of property rights in this case is certainly the concern for achieving economic efficiency — an idea borrowed from the West, as well as maintaining stability and continuity in the development of private property rights to land. As Quataert $(1994,857-861)$ argues, the Land Code of 1858 “...was deeply concerned with the fiscal health of the imperial treasury... focused on the small cultivator, but it countenanced large estates to initiate or maintain cultivation... [It] displays the modern and capitalist aspects of the evolving Ottoman state, striving to divest itself of concern for production and focus on the flow of taxes... provided a more secure legal context for entrepreneurial investors... aided in the consolidation and further development of private landholding." The motives for economic efficiency and stability, of course, cannot be separated from the goal of regaining political strength and influence 
in Europe; although belatedly, the Ottoman government seemed to realize that unlike in previous centuries, such goals would only be possible to achieve through economic development in the long run.

Turning to the social conflict theory, it can be argued that it better, although not completely, explains the case of Bulgaria. Although desired, the emergence of individual property rights was not an ultimate choice of the society as a whole. Rather, just as the theory predicts, property rights of Tanzimat were chosen by the groups that held political power at the time and was partly the result of conflict with other groups.

Following the framework of this theory, the first factor to consider is the nature of political institutions in the $19^{\text {th }}$ century. The Ottoman Empire was a theocratic monarchy, the institutions of which imposed no constraint on the actions of the Sultan as he was granted the status of representative of God on Earth. In other words, the Sultan was allocated full de jure political power to exercise whatever decisions he chose to take. The second component is the distribution of economic resources which would determine de facto political power. It is true that the Ottoman government was in conflict with âyans, sipahi, and other provincial notables who emerged as the landholding nobility of the empire and who acquired substantial degree of political and economic power during the preceding two centuries. This limitation on the de facto power of the government certainly did not originate from the political institutions of the Empire but rather from the introduction of its economic policy of tax farming. Recall that this policy came as a direct 
result of an exogenous shock: the European invention of firearms and the subsequent inevitable change in the military organization of the empire.

Nevertheless, the resources held by notables appear to be insufficient to provide them with the full de facto political power that would allow them to establish legal and full ownership to land rights by overthrowing the Sultan or by otherwise convincing him to grant those rights. Before initiating the reforms, the government recovered its de facto political power by using its de jure political power to destroy completely the çiftlik system created by notables. So, at the time of the reforms, de jure and de facto political power belonged to the reigning Sultan and his government. Having both, the Sultan controlled political power and it was precisely his administration that assigned and enforced the land tenure regime of mid- $19^{\text {th }}$ century. This brings us to the third building block of the social conflict theory, which is that political power, both de jure and de facto, determines the economic institutions, in this case, the land tenure system of a society. Moving forward to the fourth component, it can be argued that the property rights of Tanzimat had a profound influence on the agricultural performance at least of those Bulgarian peasants who were directly affected by the reforms.

Unfortunately (as far as testing the theory is of concern), the Ottoman Empire did not last long enough for us to see how it would have proceeded with the reforms and therefore to see whether and how distribution of resources and political institutions would have been affected in the future. What is of greater importance, however, is to note an important pitfall in the social conflict theory as it applies in this particular case. The theory 
maintains that both political institutions and the distribution of political power in society are endogenous. It is hard to argue that this is true in the case of Bulgaria. As discussed in the previous sections, Ottomans imposed their political and almost all other institutions on Bulgarian society as a result of their military conquest in 1393 . Not only the property rights of Tanzimat but all other changes in the land tenure institutions of Bulgaria came ultimately as a result of the military superiority of the Ottomans and subsequent ascendancy of their institutions. The implication is that there were long lasting exogenous constraints on the institutional choices that the Bulgarian society could make for itself. This in turn has an impact on which actors are relevant to understanding the conflicts that lead to the transition in property rights regimes. Moreover, the issue of the embeddedness of local regimes into broader ones comes to the picture once again: it was the complex dynamics of the empire as a whole which determined the introduction of individual property rights in Bulgaria, which continued to be an integral part of the empire for the most of $19^{\text {th }}$ century.

There is one issue which is relevant to the case of the Ottomans and which the social conflict theory is not clear about: the theory is not clear about what happens when, due to limited institutional capacity, training, and competence, the ruling elites fail to implement the economic institution which they chose to introduce. A major problem with the Tanzimat land reform of the Ottomans was that the creation and enforcement of the new property rights to land were very slow and uneven (some regions of Bulgaria were not affected at all) as the administration struggled in their implementation. This could have been because Tanzimat affirmed a principle of government without detailing a 
programme of legislation (Palairet 1997, 45). Lampe and Jackson $(1982,133)$ add that the failure was also due to "a lack of administrative will at the centre and a shortage of able officials throughout the system." Stavrianos $(2000,387-388)$ goes further on to argue that the administrators were of poor calibre and the lack of enlightened, capable, conscientious, devoted and properly educated administrators was the main reason for the eventual doom of the Ottoman Empire.

This implies that the political power of the Sultan and his government was a necessary but not sufficient condition for creating and maintaining the desired institutions. Private property rights were an institution borrowed, or as de Soto (2000) would say 'copied' from the West; they were in contradiction with the Islamic jurisprudence under which the empire operated for centuries, and as an idea were totally foreign to the near-eastern traditions and culture of the empire. Therefore, they required methods of administration different from those in which the ruling elites were educated and trained. The proper assignment, monitoring, and enforcement of these rights required a particular institutional and human capital capacity which the empire lacked. And since they were introduced from top to bottom, specific training and competence of the ruling elites and their agents were of crucial importance for their successful implementation. The evidence suggests that the empire struggled in building the institutional and human capital capacity required.

The successful introduction and enforcement of land rights in the Danubian province, for example, is often ascribed to its first governor, Midhat Pasha, who is known as the most 
able and fierce reform-minded official the Ottoman government could have ever hoped to have on hand (Draganova 2005, 25; Lampe and Jackson 1982, 149; Stavrianos 2000, 387). Other regions of the Empire, however, remained largely under the old regime for lack of, or insufficient, capacity, training and competence of the ruling elites to introduce the new institutions as they were planned or envisioned (Todorova 1976, 107). ${ }^{62}$

The social conflict theory also maintains that the agents controlling political power will choose the economic institutions that maximize their own rents. The Sultan's concern, however, was the decaying structure of the Empire as a whole and the disastrous direction it was taken into as a result of previous policies. As mentioned above, his primary goal was to provide equal rights for the population as a whole. It can be argued that saving the empire, or better yet, rebuilding it as an entity equal to or higher than that of the European empires would certainly promote or even maximize the broad selfinterests and pay-offs of the Sultan and his agents. The question is why they not chose to introduce the new land tenure earlier. Or why did they not realize earlier the superiority of individual freehold property rights ${ }^{63}$ and resisted for centuries the attempts of the Turkish notables to acquire legally those rights.

\footnotetext{
${ }^{62}$ Todorova (1976) provides a neat discussion on this topic. She demonstrates with evidence the efforts of the Ottoman administration to train its ruling elite according to the European school of thought. Nevertheless, her conclusion is that "The views of the Tanzimat personalities, their reform programs and the reforms themselves were the work of people who had not been specially trained for this, but, being aware of the need for changes, tried themselves to guess the most suitable roads. They were personalities who had mastered the traditional methods of administration during their training. They had experimented with the new methods and had became trained in the process of their own practice" (p. 110).

${ }^{63}$ Of course there were the property rights introduced by the sipahi and the ayans. But those rights were illegal and emerged against the will or intention of the Sultan and the central government. The point is that the government resisted legalizing, properly defining, monitoring, and enforcing a code for property rights for two centuries.
} 
These questions require taking into consideration the role of the external shock discussed above. At the time of reforms, the Sultan and his government seem to be already far from thinking just about their own self-interests and how to solely maximize their own rents. It is hardly a coincidence that property rights to land were introduced by the Ottomans at a time when European capitalism penetrated firmly into the sphere of the traditional command economy; a milestone of this process was the Anglo-Ottoman commercial convention of 1838 (Adanir 1989, 150). And if we follow Inalcik and other Ottoman historians who argue that the ultimate goal of the Sultan was to westernize his empire, how are we to explain that such goal equates to the goal of maximizing his own rents? The ultimate question, therefore, is whether the Ottomans would ever have decided to introduce private property rights and therefore adopt capitalist relations if it were not for the rise of European capitalism and free trade in the region. If the answer is negative, which perhaps it is (recall Pamuk's $(1987,87)$ argument that the Land Code of 1858 was enacted under pressure from European powers), we have another exogenous factor as the driving force behind the emergence of property rights in Bulgaria and in the Ottoman Empire as a whole.

To conclude this section, the underlying cause of changes in the land tenure institutions of Bulgaria during the second and third quarters of $19^{\text {th }}$ century was the desire of the central Ottoman government to reform the overall institutional structure of the empire. Such a desire arose from the pressing necessity to regain its strength and self-sufficiency and adapt to ever changing conditions brought by Western Europe. As far as Bulgaria is concerned, and similar to the earlier periods, her society had no role to play in the choice 
of property rights systems. The above analysis shows that the theoretical frameworks of institutional change provided by Demsetz and AJR are insufficient to explain the changes in the land tenure institutions of Bulgaria during this period. Consistent with AJR's theory, political institutions and distribution of resources determined prevailing political power which in turn determined the new structure of land tenure regime. But the motivations behind the new structure were broader than the Bulgarian situation and came as a result of the perceived need to 'copy' Western European institutions developed in a totally different context. Moreover, the actual establishment and enforcement of those institutions turned out to be a challenging process; political power and will alone was insufficient to successfully establish them throughout the empire.

Nevertheless, the social conflict theory of AJR is useful in organizing the factors that are identified as the determinants of property rights. With a modification in its level of analysis the theory can apply well to the case of Bulgaria. For example, the theory can be expanded to include the possibility that institutional change in a country can result from political or economic dynamics of conflict in a more encompassing political entity that contains it. In other words, the theory can be expanded to account for the possibility of local regimes being embedded into broader ones. The theory can also be expanded to account for the role exogenous factors play in the process of institutional change. Such factors were present and had significant influence both in the case of Bulgaria, and the Ottoman Empire in general. In the case of the latter, they are especially interesting. What was happening in Western Europe at the time was not just an external shock which modified political balance and to which the empire could adapt within its own social and 
politico-economic context. It was a factor that determined the Sultan's choice of institutions. 


\section{The Transition to the Post-liberation Land Tenure System of Bulgaria and its Evolution: 1878-1944}

The defeat of the Ottoman Empire in the Russo-Turkish War of 1877-1878 resulted in its loss, among others, of the territory of Bulgaria, and brought an end to its rule in the country. The liberation from almost five centuries of Ottoman domination resulted in a number of changes in the institutional structure of Bulgaria, including the structure of land tenure. This section will analyze the precise mechanisms by which the transition to the first national land tenure regime occurred and will evaluate its evolution.

The land tenure of Tanzimat was invalidated almost overnight with the arrival of the Russian occupation forces in Bulgaria in 1877, following their victory in the Russo-

Turkish War of $1877-1878$. The demise of the land tenure system of the mid-1 $19^{\text {th }}$ century was thus a direct result of the defeat of the political and military power of those who designed and enforced it - that of the Ottoman government. The overturning of the Ottoman land tenure structure in the wake of the Russo-Turkish War, rather than through a national revolution, should be considered as a crucial external mechanism of institutional change.

\section{1 The Transition to the Post-liberation Land Tenure Regime}

The end of Ottoman rule in Bulgaria brought agrarian turmoil. While the Bulgarian nation opposed both passively and, through its revolutionary movement in the $19^{\text {th }}$ century, actively, the rule and institutions of the Ottoman Empire and for that reason fully 
supported the Russian forces, it did not have specific goals to pursue with respect to the establishment of a particular type of national land tenure regime. The Bulgarian revolutionaries did not have an agrarian programme or blueprint that would dictate either the transition to - or the precise structure of - the desired new land tenure regime; in fact, with the exception of one diary, their documents show no evidence of thoughts or concerns about the type of land relations they envisioned for the nation (Konobeev 1976). ${ }^{64}$ Neither did the peasants themselves know exactly how to proceed with the reorganization of land relations in the country - what followed as a result of liberation was a spontaneous and chaotic peasant movement which aimed solely at the expropriation of land. In other words, it was a political mobilization driven by rentseeking.

The major outcome of liberation and the accompanying peasant movement is described by Berov $(1981,217-228)$ as an "agrarian coup" ${ }^{65}$, the objective of which was eliminating large Turkish landownership and establishing the dominance of small and

\footnotetext{
${ }^{64}$ Konobeev refers to a number of official documents of the Bulgarian Central Revolutionary Committee which indicate that a specific agrarian programme was not developed; rather, the desires of the nation, and therefore the goals of the Committee, were broadly defined as to bring an end to Ottoman rule and feudal exploitation, to achieve national liberation, freedom for the people, the individual, and the religion and ultimately to create a democratic republic. Only in the diaries of Liuben Karavelov who was one of the most influential revolutionaries, are found notes pertaining to his vision about the land tenure Bulgaria should have. It appears that he supported the late Ottoman land reform and the obvious benefits it brought to the peasants; he also believed that private property rights to land were essential for the wellbeing of peasants and society as a whole.

${ }^{65}$ Bulgarian and Russian Marxist scholars describe this peasant movement as either an "agrarian overthrow" or an "agrarian revolution" which had the purpose of uprooting the Ottoman feudal structure of land tenure and that in its socio-economic context such movement was no different than that of the French Revolutionaries (Khristov 1976). Such an analysis is surprising given that these sources acknowledge structures resembling feudal ones to be present only on çiftlik lands, which comprised no more than 10 percent of Bulgarian agricultural lands on the eve of liberation.
} 
medium landholdings. ${ }^{66}$ Such a characterization, however, is partly incorrect. As Berov's and other sources' discussion of the evidence shows, the objective of the coup was actually transferring, regardless of their size, as much land as possible from Turkish or state ownership to Bulgarian peasant ownership. ${ }^{67}$ As Palairet (1997, 176-179) suggests such transfer was highly advantageous to the latter as it meant greatly increased access to land.

Much of the Muslim population that had been living for centuries in Bulgaria fled the country, leaving behind their estates, whether large or small, and those who decided to stay were later treated as foreigners and were only allowed to hold up to 2.2 hectares of land (Palairet 1997, 175). Çiftliks ${ }^{68}$ were destroyed and their strips of land distributed among peasants. Based on state archival documents Berov $(1981,219)$ suggests that along with çiftliks, whole Turkish villages were often destroyed. Furthermore, this

\footnotetext{
${ }^{66}$ According to Berov, the first stage of this agrarian coup took place during and immediately after the war and was characterized with a revolutionary seizure of most of the abandoned Turkish lands by Bulgarian peasants. The second stage took place during the first half of the 1880s during which Bulgarian peasants were (in accordance with the Berlin Treaty of 1878 ) forced to buy most of the seized land from their previous owners.

${ }^{67}$ As mentioned in Section IV, Berov himself estimates that the percentage of Bulgarian land under çiftlik ownership was no more than 23 percent in places where it was most widespread at the beginning of $19^{\text {th }}$ century. According to the Russian survey of 1877, this amount was 8-10 percent (Khristov 1976). Furthermore, Todorov and Tsonev $(1981,192)$ suggest that on the eve of liberation the majority of peasants, regardless of their ethnicity, would be characterized as small owners holding 30 to 100 decares ( 8 to 25 acres) of land. Lampe and Jackson $(1982,185)$ also argue that family-owned peasant smallholding had become almost the only form of land tenure by the early $19^{\text {th }}$ century and that northern peasant proprietors effectively owned the great majority of land under cultivation by the $1860 \mathrm{~s}$, a finding strongly supported by Draganova $(1980 ; 2005)$. In 1888, ten years after liberation, the number of çiftliks on Bulgarian territory remained close to that at the time of liberation: 174 of size 500 to 1500 decares and numerous smaller ones belonging now to Bulgarian peasants (V'lchanov 1954,68). And as shown in Table 1 below, just as in the beginning of $19^{\text {th }}$ century, majority of landholdings were of size 30 to 100 decares. This implies that the pattern of landownership did not change much; what changed was the ethnicity of their holder.
}

${ }^{68}$ The word çiftlik here refers to mostly larger estates legally held by Muslim owners. Recall from Section IV of the essay that they were largely confiscated from the notables before Tanzimat and transferred as private property to now legal owners. 
chaotic, unorganized process inevitably led to harsh, sometimes bloody conflicts among peasants with respect to the way land was supposed to be distributed.

The attitude of the Provisional Russian Administration towards the agrarian upheaval in Bulgaria was somewhat confused but, in the overall, it greatly supported and facilitated the seizure of Muslim lands by Bulgarian peasants (Berov 1981, 220). As explained by Berov, the Provisional Russian Administration had, on one hand, supported the fight of peasants for more land and attempted to bring some order by distributing 'tickets' permitting the occupation of Turkish village lands or the cultivation of such lands within Bulgarian villages. Despite these attempts, however, peasants would often act as they pleased. On the other hand, the Russian officials had to take into account the demands of European powers, particularly those of Great Britain and Austria-Hungary who were concerned about the ongoing expropriation of private property and insisted that land be returned to its legal owners, the fleeing Ottoman Turks. European powers rejected the justification put forth by Bulgarians that they were simply reacquiring the lands that were forcefully taken by the Ottomans in their 1393 conquest.

The Congress of Berlin ${ }^{69}$ revoked these seizures, which involved 40 percent of cultivated land in southern regions and smaller proportions in northeast Bulgaria, unless the Bulgarian peasant could pay the former Turkish owner (Lampe and Jackson 1982, 185 -

\footnotetext{
${ }^{69}$ The Congress of Berlin is the name given to the diplomatic meeting of the major European powers and the Ottoman Empire held in June 13 - July 13,1878 in Berlin. The goal of the meeting was to revise the Treaty of San Stefano, which was the treaty between Russia and the Ottoman Empire signed on March 3, 1878 at the end the Russo-Turkish War of 1877-1878 and which established Bulgaria as an autonomous principality.
} 
186). Despite the requirements of the Berlin Treaty of 1878 , however, compensation was seldom provided for seizures and compulsory sequestrations. Of the 18 million decares of arable land, only 4.5 million decares were paid for (V'lchanov 1954, 63). The Provisional Russian Administration did everything possible to resolve the problems in favour of Bulgarian peasants - laws and regulations were designed to ease as much as possible the transfer of land from Turks to Bulgarians (Berov 1981; Stavrianos 2000, $442) .^{70}$ In some parts of Bulgaria, vast amounts of land were compulsorily transferred by the courts to peasant ownership (Berov 1979, 48). Large quantities of land were sold by emigrating Muslims in the market usually at a price much lower than that of the pre-war period and in many cases land was never paid for in full since Bulgarians viewed the process as taking back the land which was originally their own. A number of village communes bought up çiftliks collectively, and divided the holdings among their members.

\section{2 Discussion of the Theories}

Three forces were at play in establishing the foundations of the new, post-liberation land tenure of Bulgaria. The driving force was the actions of the majority of Bulgarian peasants directed towards acquiring more land and establishing their private, individual ownership to that land by all possible means. A second important force was the actions of the Provisional Russian Administration during the two years of their occupation. This

\footnotetext{
${ }^{70}$ The Berlin Treaty recognized the legal rights of Turkish landowners who were allowed to return to Bulgaria and take possession of their estates. In reality, however, they were unable to do so. The Russian Administration issued a decree according to which a returning Turkish landowner would be tried before a military court if he happens to be charged with robbery, arson, rape, murder, or other crimes. The first two landowners who attempted to reclaim their land in Bulgaria were sentenced to death (later changed to exile from the country) which set a precedence discouraging other landowners to return.
} 
was certainly an exogenous force, and in fact, the mechanism by which the transition was accomplished. The third important force was that resulting from the actions of European powers, again an exogenous factor. The difference is that European powers had interests different than those of the Russians and their impact on the distribution of land remained smaller compared to that of the Russian powers. The role of both external forces, particularly, that of the Russian powers cannot be explained by the theories of Demsetz and $\mathrm{AJR}^{71}$

One element conforms to the efficiency theory of institutional change: it is obvious that the resulting pattern of land ownership emerged spontaneously within the largely peasant society of Bulgaria. That process was certainly an endogenous one. But were peasants really in a search for adjustment to new cost-benefit possibilities? Could they actually have calculated or even have had any clear idea of the future costs and benefits of this distribution and decided that it would be a more efficient and beneficial one? In other words, was this an outcome that was long-planned and long-calculated or simply an immediate reaction to the Russian liberation?

\footnotetext{
${ }^{71}$ The history view of institutional change (discussed in AJR, 2005b) which holds that economic institutions are the by-product or unintended consequence of historical accidents may to some extent help in its analysis. It can be speculated that, if Bulgaria had been liberated not by the Russian, but by the British army, chances are small that events would have proceeded the way they did. Or, if the Russian army had taken serious measures against the actions of peasants, the outcome would again be different. What does not fit into this theory is that the incidental power or force in question is an external one, not internal. Furthermore, this external force cannot be viewed as the sole determinant of the resulting pattern of ownership: after all, however crucial their role, the Russian administration did not set the direction of events, it supported the desires and goals of peasants and eventually provided for their accomplishment. Undoubtedly, the Russians had interests in supporting whatever goals the peasants had set, or they might have wanted events to develop precisely the way they did. The discussion of those interests, however, falls outside of the scope of the thesis mostly because of their broad political nature and because Russians do not seem to have directly benefited from the type of land ownership to be established in Bulgaria at that time.
} 
The answers to both questions seem to be negative. Given the nature of the events, it can be argued that peasants acted in their own immediate self-interest and were simply trying to increase their own rents. The march of the Russian army into Bulgaria and the disorder resulting from the conditions of war opened the way for a broad and nearly costless access to land which implied benefits for those who managed to acquire as much of it as possible. Indeed, it was not only former Turkish land that was expropriated: state land, such as meadows, grain fields, pastures, and forests were seized as well (V"lchanov 1954, 60). V'lchanov also argues that the resulting distribution was unjust and inequitable since richer peasants (medium or larger landholders) were more willing and eager to acquire additional land as they had the draught animals to work that land; poorer peasants had less chance to acquire more land.

Turning to the second question - was there actually a prior 'calculation' of the future costs and benefits of this distribution and a prior decision that it would be a more efficient and beneficial one - the answer seems also to be negative. Given the discussion of Konobeev (1976) on the lack of a precise programme for a new land tenure system, it is hardly the case that there was a calculation of the costs and benefits of regimes and subsequent choice towards a more efficient one. The resulting land ownership pattern was perhaps not even expected as it came as a direct consequence of anarchy and disorder.

By one means or another, by the end of the $19^{\text {th }}$ century many people became land owners for the first time but their holdings were mostly of small or medium size. Table 
I. 2 shows the distribution of land as measured by the first official agricultural census performed in 1897 . Of the country's $9,634,550$ hectares, $7,413,747$ were classified as usable land; 53.65 percent of this usable land was in private ownership and 30.91 percent belonged to village communes (Crampton 1983, 186). As can be seen, the majority of land owners were small (2-10 hectares) and very small (less than 2 hectares) peasant proprietors with the latter being more than forty five per cent of landholders. Two hectares is an amount considered below the minimum to provide a livelihood so that these landowners would have needed other sources of income. More than anything else, the distribution seems quite egalitarian.

Table I. 2 Distribution of Land Holdings by Size of Holding in 1897

\begin{tabular}{|c|c|c|c|c|c|}
\hline Size of holdings & $\begin{array}{c}\text { Number } \\
\text { of } \\
\text { holdings }\end{array}$ & $\begin{array}{c}\text { Average } \\
\text { size of } \\
\text { holdings }\end{array}$ & $\begin{array}{c}\text { Percentage } \\
\text { of total } \\
\text { holdings }\end{array}$ & $\begin{array}{c}\text { Area of } \\
\text { land } \\
\text { (hectares) }\end{array}$ & $\begin{array}{c}\text { Percentage } \\
\text { of total } \\
\text { area }\end{array}$ \\
\hline $\begin{array}{c}\text { Very small } \\
\text { (less than 2 hectares }\end{array}$ & 363,646 & 1.5 & 45.48 & 265,653 & 6.68 \\
\hline $\begin{array}{c}\text { Small } \\
\text { (2 to 10 hectares) }\end{array}$ & 334,384 & 5.8 & 41.82 & $1,681,119$ & 42.27 \\
\hline $\begin{array}{c}\text { Medium } \\
\text { (10 to 30 hectares) }\end{array}$ & 92,509 & 15 & 11.57 & $1,409,890$ & 35.44 \\
\hline $\begin{array}{c}\text { Large } \\
\text { (greater than 30 hectares) }\end{array}$ & 9,049 & 110 & 1.13 & 620,896 & 15.61 \\
\hline Total & 799,588 & & 100 & $3,977,558$ & 100 \\
\hline
\end{tabular}

Source: Crampton 1983, $187 .^{72}$

\footnotetext{
${ }^{72}$ Categories for the size of holdings are described as follows: "very small-those below twenty decares in extent and insufficient to support the average peasant household; small-from twenty to 100 decares, and large enough to support the average peasant family; medium - from 100 to 300 decares and large enough to provide surplus for the market and perhaps to need the occasional employment of labour from outside the family; large - over three hundred decares, needing full time wage labour to work, and if not subdivided and rented, clearly capable of capitalization and commercialization. An approximation would suggest that
} 
If the efficiency theory seems not to explain the transition, what about the social conflict theory? With one caveat concerning its first two blocks, the social conflict theory appears to better explain the case of Bulgaria. The caveat is that, immediately before the time of the peasants' 'agrarian overthrow", Bulgaria did not have its own political institutions; they were yet to be developed after 500 years of Ottoman rule. Instead, what were present were the Ottoman political institutions which assigned de jure political power to the Sultan and his administration. At that time, de facto political power also belonged to the Sultan. Almost unexpectedly, the Russian victory provided not only for the elimination of this power but also for the acquisition of economic (and later, as will be seen below, political) power by peasants. In other words, the conflict between Bulgarian peasants and the group in political power was resolved through the Russian victory in favour of the peasants.

This is somewhat in contrast to the theory which predicts that it is the distribution of resources in society that will determine de facto political power and will consequently determine which group's power will prevail. "Somewhat in contrast" because, (1) peasants did not need to overthrow or exercise any sort of power upon the group in political power in order to achieve their objectives; this had already been done by the Russians; and (2) it was the distribution of economic resources which determined their de facto political power but these economic resources were acquired directly as a result of

the very small averaged 15 decares, the small 58 decares, the medium 150 decares and the large 1,100 decares. Most families had enough land for their own needs and no more than two percent of the population at the end of $19^{\text {th }}$ century, when conditions in the countryside were particularly bad, had been forced into full-time wage-labouring" (Crampton 1983, 187-188) 
the Russian victory and of the subsequent actions of the Provisional Russian Administration.

To clarify, the Russian army replaces "political institutions" in the following relationship in the social conflict framework:

political institutions $t \quad \rightarrow \quad$ de jure political power $t$

and the Provisional Russian Administration in Bulgaria replaces "distribution of resources," in the second social conflict relationship:

\section{distribution of resources $t_{t} \rightarrow \quad$ de facto political power $t$}

There are several important conclusions to be made here. In line with both theories, the process of institutional change was an endogenous one as, whatever their motives, it occurred as a result of peasants' actions, individual or collective. What does not confirm to Demsetz's theory is that there was no particular economic reason for which peasants would undertake the transformation. The timing and nature of the events and particularly their response to these events suggest that peasants were driven by nothing but their selfinterests and the desire to maximize their own rents. There does not seem to be any evidence that they had hoped or realized that the resulting distribution of land could eventually lead to more efficient economic outcomes. The next section will show that, actually, the new land tenure regime evolved in the direction of inefficiency. Also, once again we come across the problem in Demsetz's theory that it does not specify the 
mechanism of transition to the new property rights system. It seems impossible that Bulgarian peasants would have ever achieved a transition on their own. The transition was accomplished through an exogenous mechanism - the Russian victory in the war and the presence of the Provisional Russian Administration in the country.

With respect to AJR's theory, it will be seen in the next section that it applies well to the case of Bulgaria. The only issue of consideration is the mechanism of transition and the key actors involved. In line with the theory, the driving force behind institutional change was the self-interests of the peasants. However, on the eve of liberation from Ottoman rule, peasants were not a source of economic or political power; therefore, they could not have had the opportunity to impose their wishes by successfully opposing the political power in rule (the Ottomans). Instead, it was an external force, the Russian army, which overthrew the Ottoman government and therefore took its political institutions and political power away. With their broad acquisition of land, which was supported and facilitated by the Provisional Russian Administration, peasants gained economic resources and immediately became an important political power. Most of them were still poor but they were now landowners and constituted the overwhelmingly large majority of Bulgarian society at the time. It can be suggested that the theory be expanded to include the possibility of exogenous sources determining or influencing economic and therefore political power. 


\section{3 The Evolution of the Post-liberation Land Tenure Regime: 1880-1944}

This section traces the post-liberation history of the Bulgarian land tenure system.

In February 1879, the Great National Assembly which was to build independent Bulgaria's political institutions adopted the liberal T"rnovo Constitution and proclaimed a Bulgarian Constitutional Monarchy. The Great National Assembly was elected on the basis of universal male suffrage; the authority of the monarch was strictly limited; a democratic government was formed and the constitution guaranteed freedom of speech, assembly, the press, and religion.

By the end of the $19^{\text {th }}$ century most of the land acquired by peasants was legitimized and its owners were given full titles of ownership rights (V'lchanov 1954, 69). A serious problem, however, was the failure to establish a land register which facilitated further heavy expropriation of state land since the boundaries between private and state property remained indistinct (Crampton 1983, 359).

Establishing individual ownership of land, in itself, did not significantly alter the structure of agriculture. The radical reform was mostly limited to distribution of land which became a permanent issue of concern until 1944. On the other hand, little was done to create the institutions necessary to support private ownership of agricultural land (Cochrane 1993).

In the first five years following independence, taxes levied on peasants were lower than those imposed by the Ottoman government. However, they rose steadily afterwards, 
parallel to the steady increase in state revenue demands (Bell 1977, 13-14). The newly formed state needed revenue to support its building projects and the establishment of its civil bureaucracy but it mostly needed revenue to cover its military expenses. In the pre1944 period of national independence Bulgaria was involved in four wars and its pursuit of aggressive and expansionist foreign policy resulted in dramatic changes of its territory. Such goals required the maintenance of growing military forces and the easiest way to meet the resulting rising military revenue demands was to tax the peasant masses - a practice resembling that of the Ottoman state during the $17^{\text {th }}$ and $18^{\text {th }}$ centuries. Crampton $(1983,208)$ argues that whatever form the taxation on the land assumed the peasants felt with a good deal of justice that the burden was unfair and constantly increasing. Most of the time, the peasants were subject to taxes much higher than those of officials, members of the free professions, and merchants. ${ }^{73}$

With respect to land tenure, the most vigorous policy pursued by the government was to break up remaining or newly formed large estates (considered as holdings greater than 300 decares $\approx 74.1$ acres) and to prevent the formation of new large estates. In other words, the goal was to achieve an egalitarian distribution of land. The first Bulgarian Land Law of 1880 provided for the distribution of previously uncultivated land to peasants in small parcels (Strezov 1913, 45; V"lchanov 1954, 66). ${ }^{74}$ The amount of land a household would be entitled to hold would range between 40 to 60 decares ( 9.88 to 14.82

\footnotetext{
${ }^{73}$ Comparing the tax burden of the Bulgarian peasant with that of the Belgian and English peasants, Crampton states that "... the Bulgarian peasant was paying $12.5 \%$ of his income on tax, compared to the Belgian's 6.5\% and the Englishman's 7.5\%." Moreover, the punishment for failing to pay taxes was in many cases execution.

${ }^{74}$ The law, according to V"lchanov, provided only use rights: peasants who settled on this "new" land were not allowed to sell or transfer those rights. Ownership of land and transfer of rights would be granted only after 10 years of use. The law was amended in 1902 to increase the period of use before eligibility for ownership from 10 to 20 years.
} 
acres) depending on its subsistence needs (V'lchev 1999, 36). ${ }^{75}$ Next, the Law of 1885 required the disintegration of remaining large estates, which, accordingly, were either confiscated or bought out by the state from their owners to be parcellized and distributed to peasants (Strezov 1913, 46; V"lchanov 1954, 66-67; V"lchev 1999, 35-37). ${ }^{76}$ According to both laws, the maximum amount of land a household could hold was 100 decares ( 24.7 acres). V"lchev explains that the rationale behind the laws was the principle that "the land belongs to those who cultivate it"; therefore, the condition to be or become a landowner was that the owner directly cultivate his land. Essentially, the Law of 1885 illustrated the stand of the state against large ownership of land.

As V"Ichanov points out, the process of dividing large estates was complicated, difficult to implement, and took many years to take effect. In fact, between 1897 and 1908 , the enforcement of the law was rather ineffective since there was actually a 20 percent increase in the number of farms larger than 100 decares. $^{77}$ It is true that those were the years when there was a general expansion in land under cultivation, which led to an increase in the number of farms in all size ranges. In spite of this, if the law had been enforced effectively, there should have been a decrease in the number of farms larger than 100 decares.

\footnotetext{
${ }^{75}$ Toshev $(1937,16)$ argues that 35 decares would be perfect for a household composed of 5 members to meet its needs.

${ }^{76}$ The Law of 1885 is actually an amendment to the principal Law of 1880 , which was also amended in 1883,1896 and 1908. According to V'lchev the amendment of 1885 is the most comprehensive version of all.

${ }^{77} 100$ decares in itself is not a large size for an estate but as mentioned in the previous paragraph, the law required that the maximum amount of land a household could hold was precisely 100 decares. In other words, any estate larger than 100 decares was considered large enough to be divided.
} 
The Bulgarian Agrarian National Union (BANU) was formed in 1899 to voice the protests of the peasants against the government's increasing tax demands. It has to be mentioned here that despite the democratic form of government, political power tend to be concentrated in the hands of a politically active elite composed of the few large merchants, landowners, lawyers, and military officers who were educated abroad (Bell $1977,5)$. BANU grew rapidly because of its broad social base and the very fact that it was formed as a peasant organization (Pantev 1996, 12). Led by the young and charismatic Stamboliiski, who was the dominant figure within BANU, the Agrarian party won the parliamentary elections of 1920 with a significant majority of 109 seats (Stavrianos 1958, 646). The egalitarian policies and social reform promised by Stamboliiski attracted all peasants but particularly those with small land holdings. The latter accounted for more than fifty percent of BANU membership. ${ }^{78}$

In 1921, the newly formed Agrarian government of BANU passed the Law of Labour Land Property. As Bell $(1977,162)$ notes, "just as 'private property' and 'social or communal property' are ideas fundamental to capitalism and to socialism, so the idea of

\footnotetext{
${ }^{78}$ Crampton $(1983,335)$ describes the political vision of Stamboliiski as follows: "His objective was a society which could offer justice and equality for all. He believed these goals could not be achieved without private property which was 'the motive force for work and progress' and which would give men satisfaction and a sense of purpose and dignity. At the same time he insisted that there were two aspects of human nature, an individual and a communal; private ownership satisfied the needs of the individual aspects of human nature but as productive relationships became more complex a communal consciousness would develop as it becomes obvious that the well-being of one was dependent on the well-being of others. As communal consciousness developed private farming would shed its primitive, individualist form and become more communal, though ownership would remain private. With his belief in private ownership went a Jacobin-like hatred of excess. No-one must be allowed to own too much and no-one must be left with too little private property, for from such inequalities all injustices stemmed, and it was this aspect of his ideology which allowed him and BANU to campaign for the confiscation of excess property from individuals and institutions such as the state and the Church, the property so taken being used to establish a fund to provide the means of subsistence for those who did not have enough land. It also led BANU to argue for state assistance to cooperatives. Stamboliiski hated all deviations from the simple village life, and saw them as destructive of the potential for human improvement."
} 
'labour property' [trudova sobstvenost] became a cornerstone of Agrarian policy." Bell (p. 163) further explains that labour property referred to property directly utilized by its owner to provide for himself and his family. Therefore, Article 1 of the law stated that "the land must belong to those who cultivate it" (V"lchanov 1954, 89). Accordingly, the law decreed that all privately owned land in excess of 300 decares $(74.1$ acres) and not farmed directly by its owner be transferred to the state (p. 90). In addition, the landholdings of absentee owners were to be confiscated and distributed to those who own less than 10 decares of land (Bell 1977, 164; Pantev 1996, 15). So the Land Law of 1921 allowed peasant farmers and all other private parties to own the maximum of 300 decares of arable land and obliged everyone who owned land to farm it directly. ${ }^{79}$ Therefore, remaining large estates and $z a d r u g a^{80}$ common lands would be subject to subdivision with resulting excess land property being subject to expropriation to be redistributed to peasants who did not own land (Crampton 1997, 152; McIntyre 1988, 25; Strezov 1913, Toshev 1937, V"lchanov 1954, 90-91).

Despite the slow pace of implementing the expropriation and redistribution, by the mid1920 s, there remained only a few individuals who continued to own large estates and the majority of land holdings could be classified as small. ${ }^{81}$

\footnotetext{
${ }^{79}$ As Bell $(1977,165)$ explains "Land owned by monasteries, but not farmed by monks, was made subject to confiscation. Land held by the National and Agricultural Banks and all state-owned arable land not under cultivation were added to the state land fund." Moreover, land over 40 decares held by absentee owners were also subject to confiscation (p. 164).

${ }^{80}$ As explained earlier, zadruga is a form of extended household organization, historically common among the Balkan nations. It was formed of two or more biologically related families who commonly owned and managed their properties, labour and means of subsistence (Todorova 2002, 123).

${ }^{81}$ Bell argues that the enforcement of the laws and reforms was more successful compared to that of the previous laws. Nonetheless, the state did not completely achieve its goal: while it expected to acquire approximately 230,000 hectares, by 1923 , when this government was overthrown, this amount was just less than 82,000 (p. 166).
} 
Social democratic policies which dominated in the beginning were halted by a fascist coup and the totalitarian rule of 1923-1944. Stamboliiski was brutally murdered in a reactionary coup by right-wing forces in 1923 but the land laws passed by his government remained in effect; the totalitarian government does not seem to have had problems with his land policies. According to Stavrianos, by 1926, 80.6 per cent of the peasants owned the land they tilled, 16.8 per cent owned plots but were willing to rent more and 2.6 per cent rented all the land they worked. By 1934, when the Military League established a dictatorship, 94 per cent of the land consisted of holdings less than 300 decares with 87 per cent at a size less than 100 decares (Thompson 1993). In 1941, distribution of land was still an issue of concern as Article 1 of The Land Law of 1941 stated that its goal was the creation of a state land fund to fight the hunger for land and unemployment in agriculture (V'lchanov 1954, 93).

\section{4 Further Discussion of the Theories with respect to the Post-liberation Period}

Can the efficiency theory explain the subsequent developments in the land tenure of postliberation Bulgaria? The theory predicts that property rights evolve in the direction of efficiency, so the question of concern is: was the resulting allocation of land resources more efficient than that of the previous land tenure regime or increasing land productivity set as the major goals to pursue? It does not seem so.

The major actors involved in the process of change were the peasants and governments who designed and enforced land legislation aimed at achieving equality and providing the minimum amount of land for subsistence. These actors might have believed that 
agricultural productivity would be enhanced by egalitarian peasant ownership of land. But if such was the case, then one would have expected efforts and policies to improve farming methods such as increasing investments in agricultural technology, the use of fertilizers, irrigation, storage facilities, and others. This was not the case. It seems that what mattered for both groups of actors was whether peasants had enough land to meet their subsistence needs. Moreover, for the government, peasants, who represented the overwhelming majority of Bulgarian population in the first half of the $20^{\text {th }}$ century, were the easiest group to target for tax collection.

Producing surplus for the market and therefore increasing profits did not seem to be of concern to anyone. The government did little to support agriculture - aggregate state expenditure on agricultural improvements was less than five percent of the total budget (Lampe and Jackson 1982, 191). ${ }^{82}$ Agricultural methods remained primitive and ultimately little was done, with or without governmental help, so that per capita productivity and yields per acre remained low by Central or Western European standards (Spulber 1963, 348, 355). Furthermore, changing the distribution of land towards its more efficient allocation through, for example, a broad division of labour, as Spulber (1963, 375) suggests, was out of question. Changing the distribution of land by leaving it to market forces was also out of question — the laws defining and greatly constraining the amount of land an individual could hold were never changed.

\footnotetext{
${ }^{82}$ This number is considered too low given that, at the time, majority of the population was engaged in agriculture, which on the other hand constituted the only sector of the economy.
} 
This brings us to the argument of Baland and Platteau (1998) and others that, the influence of the state can lead to the direction of both efficiency and inefficiency and that in many cases state intervention can disturb the evolutionary sequence of property rights. It is obvious that the intervention of the state in terms of restricting the amount of land a person can hold had adverse effect on both the development of agriculture and land relations and it certainly disturbed the evolutionary sequence of land tenure - by imposing the ownership only of small farms, the state seemed to wish that peasants live and produce only for subsistence. It provided security and protection of rights to pieces of land which could only be used to barely feed a family. Such a situation was highly advantageous to the state: it could successfully tax the majority of the population and meet its short term goals of revenue collection.

Turning to the social conflict theory, independent Bulgaria established democratic political institutions which allocated de jure political power to elected governments, at least until 1923. The economic resources acquired in the course of the Russo-Turkish war of 1877-1878 made peasants the holders of de facto political power. These two sources of political power chose to establish individual property rights to land. The defining characteristic of the new land tenure was an egalitarian access and distribution of land which seemed to maximize the rents of both groups - peasants were concerned with possessing landownership rights which would allow their subsistence and the government was concerned with collecting taxes. Being in conflict with the state which was continuously increasing their tax burden, peasants peacefully opposed the policies of the state and democratically established an agrarian government which would protect their 
interests. This government however was overthrown by another group with political power who opposed the agrarian government for its foreign policies; the land policies of the agrarian government remained untouched until 1944, throughout the totalitarian regime. It can be concluded that the social conflict theory is effective in explaining the evolution of the post-liberation lad tenure regime. 


\section{Conclusion}

The goal of this essay was to identify and examine the critical factors which determined the shape of the land tenure institutions of Bulgaria and influenced their evolution. The focus of analysis was the period 1839-1944. The question was addressed through a critical evaluation of the theoretical frameworks of institutional change proposed by Demsetz (1967) and Acemoglu, Johnson, and Robinson (2005b).

The major conclusions of this essay can be summarized as follows. First, changes in the land tenure institutions of Bulgaria prior to 1878 were of an exogenous nature. From the $15^{\text {th }}$ to the end of the $19^{\text {th }}$ century Bulgarian society lived under the imposition of the foreign land tenure institutions of the Ottoman Empire. As those institutions evolved, Bulgarian society adapted itself to and was greatly affected by these changes but it did not have any role to play in the process of institutional change. The long lasting military superiority of the Ottoman Empire brought long lasting constraints on the institutional choices of Bulgaria. In this important respect the Bulgarian experience does not conform to the theories of Demsetz and AJR which maintain firmly that the process of institutional change is an endogenous one and leave aside the possibility that the determinants of change may not lie within the society whose property rights regime is being considered. If this possibility is ignored, however, both theories would lead to interpretative dead ends. The discussion of the evidence on the land tenure institutions of Bulgaria challenges the endogeneity view and suggests that exogenous factors may play a critical role in shaping the institutions of a society. On the other hand, the process of institutional 
change was an endogenous one for the Ottoman Empire. Taking into account the possibility that local regimes may be embedded into broader ones, whose economic efficiency or rent-seeking dynamics are determinant in the process of change, the essay suggests that the social conflict theory be expanded to include the embeddedness factor and the role of external factors in the study of institutional change.

Second, the process of introduction of individual property rights to land in Bulgaria in the mid- $19^{\text {th }}$ century conforms generally to the theoretical framework put forth by AJR: the political institutions and distribution of resources in the Ottoman Empire determined the prevailing political power which on the other hand determined the choice of institutions. However, for this period too, the embeddedness issue and the role of external factors appear to be an issue of consideration: (1) the identified determinants were still exogenous to the Bulgarian institutional environment - an issue which can be resolved with the inclusion of the embeddedness factor; (2) the reasons for which property rights to land were introduced did not directly relate to the concern of maximizing the rents of the group in political power (the Ottoman government), at least not if we define rents in a narrow economic sense. Rather, they were directly related to critical changes in the international environment which influenced the available choices - this can also be addressed by taking into consideration the role of external factors.

Third, the process of transition from the $19^{\text {th }}$ century Ottoman land tenure regime to the national one was an endogenous process as it emerged as a result of spontaneous peasant actions which ultimately laid the foundations of the new pattern of landownership. But it 
was also a process whose technical implementation was only achievable through an exogenous mechanism. The impact of European and particularly Russian powers on the direction of change was significant; that of the latter crucial. This fact is all the more interesting for although not directly interested in or benefiting from the particular form of land tenure institutions to be established in Bulgaria, Russian powers intervened and played active role in the process. Certainly, implementing a policy that clearly was immensely popular with the majority of the population was in their interest. Finding out whether Russian interests were limited to that requires the close examination of the nature and precise goals of external interest groups. In any case, this finding once again brings attention to the role of exogenous factors in the process of institutional change in Bulgaria.

It can be concluded that the emergence and evolution of individual property rights to land in Bulgaria was a political process heavily influenced by the self-interests and rentseeking behaviour of the key actors involved. The example of Bulgaria provides evidence in support of other studies which suggest that property rights are determined and created through political processes. A specific contribution of this study is that it draws attention to the issue of embeddedness of local regimes into broader ones and the significant role which external factors may play in the process of institutional change. Therefore, the essay suggests that these two issues be taken into consideration in the study of the evolution of property rights. 


\section{References}

Acemoglu, Daron, Simon Johnson, and James A. Robinson. 2001. The Colonial Origins of Comparative Development: An Empirical Investigation. American Economic Review 91 (5): 1369-1401.

Acemoglu, Daron, Simon Johnson, and James A. Robinson. 2002a. Reversal of Fortune: Geography and Institutions in the Making of the Modern World Income Distribution. The Quarterly Journal of Economics 117 (4): 1231-1294.

Acemoglu, Daron, Simon Johnson, and James A. Robinson .2002b. An African Success Story: Botswana. CEPR Discussion Paper no. 3219. London: Centre for Economic Policy Research.

http://www.cepr.org/pubs/dps/DP3219.asp

Acemoglu, Daron. 2004. Understanding Institutions. Lionel Robbins Lectures, February 23-25, London School of Economics Public Lecture and Events, London, UK. http:/www.lse.ac.uk/collections/LSEPublicLecturesAndEvents/ppt/20040223DaronAce mogluRobbinsLectures.ppt.

Acemoglu, Daron, Simon Johnson, and James A. Robinson. 2005a. The Rise of Europe: Atlantic Trade, Institutional Change and Economic Growth. American Economic Review 95 (3): 546-579.

Acemoglu, Daron, Simon Johnson, and James A. Robinson. 2005b. "Institutions as the Fundamental Cause of Long-Run Growth." In Handbook of Economic Growth, ed. Philippe Aghion and Stephen Durlauf, 385-472. Amsterdam: North-Holland.

Adanir, Fikret. 1989. "Tradition and Rural Change in South-eastern Europe during Ottoman Rule." In The Origins of Backwardness in Eastern Europe: Economics and Politics from the Middle Ages until the Early Twentieth Century, ed. Daniel Chirot, 131176. Berkley: University of California Press.

Agrawal, Arun and Elinor Ostrom. 2001. Collective Action, Property Rights and Decentralization in Resource Use in India and Nepal. Politics and Society 29 (4): 485514.

Aku, P. S. 1986. Lending to Farmers through the Commercial Banks in a Developing Economy: The Nigerian Experience. Agricultural Systems 22 (1): 23-32.

Alchian, Armen A. and Harold Demsetz. 1973. The Property Right Paradigm. The Journal of Economic History 33 (1): 16-27.

Alston, Lee J., Gary D. Libecap, and Robert Schneider. 1996. The Determinants and Impact of Property Rights: Land Titles on the Brazilian Frontier. The Journal of Law, Economics, and Organization 12 (1): 25-61. 
Anderson, Terry L. 1996. Conservation Native American Style. PERC Policy Series PS6. Bozeman, MT: Property and Environment Research Center. http://www.perc.org/perc.php?id=651

Anderson Terry L. and Dean Lueck. 1992. Land Tenure and Agricultural Productivity on Indian Reservations. Journal of Law and Economics 35 (2): 427-454.

Anderson, Terry L. and Laura E. Huggins. 2003. Property Rights: A Practical Guide to Freedom and Prosperity. Stanford, CA: Hoover Institution Press.

Anderson, Terry L. and Peter J. Hill. 1975. The Evolution of Property Rights: A Study of the American West. Journal of Law and Economics 18 (1): 163-179.

Aron, Janine. 2000. Growth and Institutions: A Review of the Evidence. World Bank Research Observer 15 (1): 99-135.

Atwood, David. A. 1990. Land Registration in Africa: The Impact on Agricultural Production. World Development 18 (5): 659-671.

Baland, Jean-Marie and Jean-Philippe Platteau. 1998. Division of the Commons: A Partial Assessment of the New Institutional Economics of Land Rights. American Journal of Agricultural Economics 80 (3): 644-650.

Banner, Stuart. 2002. Transitions between Property Regimes. Journal of Legal Studies 31 (2): S359-S371.

Bates, Robert H. 1995. "An Assessment of the New Institutionalism." In The New Institutional Economics and Third World Development, ed. John Harriss, Janet Hunter, and Colin M. Lewis, 27-48. New York: Routledge.

Bell, John D. 1977. Peasants in Power. Princeton: Princeton University Press.

Benham, Alexandra and Lee Benham. 1997. "Property Rights in Transition Economies: A Commentary on What Economists Know." In Transforming Post-Communist Political Economies, ed. Joan M. Nelson, Charles Tilly, and Lee Walker, 35-60. Washington DC: National Academies Press.

Berov, Lyuben. 1956. Agrarnoto dvizhenie v Iztochna Rumeliya po vreme na Osvobozhdenieto. Istoricheski Pregled no. 1:3-35.

Berov, Lyuben. 1979. "Ravnishte na ikonomicheskoto razvitie na B"lgarskite zemi po vreme na Osvobozhdenieto." In Trudove na Visshiya Ikonomicheski Institut "Karl Marks," Vol. 1, 19-29. Sofia: Vissh Ikonomicheski Institut Karl Marks.

Berov, Lyuben. 1981. "Ikonomicheskoto razvitie na B"lgariya ot Osvobozhdenieto do kraya na XIX v." In Stopanska Istoriya na B"'lgariya 681-1981, ed. Dimit"r Angelov, 
Nikolay Todorov, Bistra Tsvetkova, Stefan Tsonev, Lyuben Berov, Velizar Velkov, Lalyu Radulov, Georgi Petrov, Dimit"r Vasilev, Stefan Tsankov, Tasho Pachev, Mito Isusov, Gatyu Gatev, Radi Radev, and David Koen, 217-262. Sofia: D"rzhavno izdatelstvo nauka i izkustvo.

Blum, Jerome. 1957. The Rise of Serfdom in Eastern Europe. The American Historical Review 62 (4): 807-836.

Boserup, Ester. 1965. Conditions of Agricultural Growth: The Economics of Agrarian Change under Population Pressure. New York: Aldine.

Boyd, Michael. 1991. The Evolution of Agrarian Institutions: The Case of Medieval and Ottoman Serbia. Explorations in Economic History 28 (1): 36-53.

Bruce, John W. 1998. Review of Tenure Terminology. Tenure Brief No. 1. Tenure Brief Series of the Land Tenure Center Institute of the University of Wisconsin, Madison. http://pdf.wri.org/ref/bruce 98 review tenure.pdf

Cholpanov, Boris. 1993. Zemya na svetoven kr"stop"t. Sofia, Bulgaria: Izdatelstvo na B'lgarskata akademiya na naukite.

Clague, Christopher, Philip Keefer, Stephen Knack, and Mancur Olson. 1997. Institutions and Economic Development: Growth and Governance in Less-Developed and PostSocialist Countries. Baltimore: The Johns Hopkins University Press.

Coase, Ronald H. 1937. The Nature of the Firm. Economica 4 (16): 386-405.

Coase, Ronald H. 1960. The Problem of Social Cost. Journal of Law and Economics 3 (1): $1-44$.

Cochrane, Nancy J. 1993. Central European Agrarian Reforms in a Historical Perspective. American Journal of Agricultural Economics 75 (3): 851-856.

Collier, Paul. 1983. Malfunctioning of African Rural Factor Markets: Theory and a Kenyan Example. Oxford Bulletin of Economics and Statistics 45 (2): 141-172.

Cornia, Giovanni A. and Vladimir Popov. 2001. Transition and Institutions: The Experience of Gradual and Late Reformers. Oxford: Oxford University Press.

Crampton, Richard J. 1997. A Concise History of Bulgaria. Cambridge: Cambridge University Press.

Crampton, Richard J. 1983. Bulgaria 1878-1918: A History. New York: Columbia University Press.

Curtis, Glenn E. 1993. "Historical Setting.” In Bulgaria: A Country Study, ed. Glenn E. 
Curtis, 1-57. Washington, D.C.: Federal Research Division, Library of Congress.

Daudelin, Jean. 2005. Alternative Dispute Resolution in Land Conflicts: A Tentative Assessment. Published as "Resolução alternativa de disputas em conflitos de terra: uma avaliação provisória." in Gestão de Conflitos de Terra e Reforma Agrária no Brasil, ed. A. M. Buainain, 1-52. Campinas, Brasil: Editora da Universidade de Campinas, Coleção Instituições, Agricultura e Desenvolvimento Sustentável.

Davis, Lance E. and Douglas C. North. 1971. Institutional Change and American Economic Growth. Cambridge: Cambridge University Press.

De Alessi, Luis. 2003. “Gains from Private Property: The Empirical Evidence.” In Property Rights: Cooperation, Conflict, and Law, ed. Terry L. Anderson and Fred S. McChesney, 90-112. Princeton: Princeton University Press.

Deininger, Klaus. 2003. Land Policies for Growth and Poverty Reduction. A World Bank Policy Research Report. Washington D.C.: The World Bank and Oxford University Press.

Deininger, Klaus and Gershon Feder. 1999. Land Institutions and Land Markets. World Bank Policy Research Working Paper no. 2014. Washington, D.C.: The World Bank.

Deininger, Klaus and Hans Binswanger. 1998. The Evolution of the Bank's Land Policy. Mimeo. Washington D.C.: The World Bank.

Demsetz, Harold. 1967. Toward a theory of property rights. American Economic Review 57 (2): 347-359.

De Soto, Hernando. 2000. The Mystery of Capital: Why Capitalism Triumphs in the West and Fails Everywhere Else. New York: Basic Books.

Dimitrov, Vesselin. 2001. Bulgaria: The Uneven Transition. New York: Routledge.

Dimitrov, Strashimir. 1956. K"m V"prosa za otmenyavaneto na spahiyskata sistema v nashite zemi. Istoricheski Pregled no. 6:27-58.

Domar, Evsey D. 1970. The Causes of Slavery or Serfdom: A Hypothesis. The Journal of Economic History 30 (1): 19-32.

Draganova, Slavka T. 1980. Materiali za Dunavskiya vilaet: Rusenska, Silistrenska, Shumenska i Tutrakanska kaza prez 50-te- 70-te godini na XIXv. Sofia: Izdatelstvo na B'lgarskata akademiya na naukite.

Draganova, Slavka. 1985. Berkovskoto selo v navecherieto na Osvobozhdenieto. Sofia: Izdatelstvo na B"lgarskata akademiya na naukite. 
Draganova, Slavka. 1996. Kyustendilski region 1964-1919: Etnodemografsko $i$ sotsialnoikonomichesko izsledvane. Sofia: Akademichno izdatelstvo "Prof. Marin Drinov."

Draganova, Slavka T. 2005. Selskoto naselenie na Dunavski vilaet. Sofia: Avangard Prima.

Eggertsson, Thráinn. 1990. Economic Behaviour and Institutions. Cambridge: Cambridge University Press.

Engerman, Stanley L. and Kenneth L. Sokoloff. 2001. Inequality, Institutions, and Differential Paths of Growth among New World Economies. Economia 3 (1): 41-109.

FAO. 2002. "What is Land Tenure?" In Land Tenure and Rural Development. Land Tenure Studies 3. Rome: Food and Agriculture Organization of the United Nations (FAO). http://www.fao.org/DOCREP/005/Y4307E/y4307e05.htm\#bm05

Feder, Gershon and David Feeney. 1991. Land Tenure and Property Rights: Theory and Implications for Development Policy. World Bank Economic Review 5 (1): 135-153.

Feder, Gershon, Tongroj Onchan, Yongyuth Chalamwong, and Chira Hongladarom. 1988. Land Policies and Farm Productivity in Thailand. Baltimore: John Hopkins University Press.

Field, Alexander J. 1981. The Problem with Neoclassical Institutional Economics: A Critique with Special Reference to the North/Thomas Model of Pre-1500 Europe. Explorations in Economic History 18 (2): 174-198.

Furubotn, Erik G. and Rudolf Richter. 1997. Institutions and Economic Theory: The Contribution of the New Institutional Economics. Ann Arbour: The University of Michigan Press.

Gandev, Khristo. 1962. Zarazhdane na kapitalisticheski otnosheniya v chiflishkoto stopanstvo na severozapadna B"lgariya prez XVIII Vek. Sofia: Izdatelstvo na B"lgarskata akademiya na naukite.

Granovetter, Mark. 1985. Economic Action and Social Structure: The Problem of Embeddedness. American Journal of Sociology 91 (3): 481-510.

Hall, Peter and David Soskice. 2001. "An Introduction to Varieties of Capitalism." In Varieties of Capitalism, ed. Peter Hall and David Soskice, 1-69. Oxford: Oxford University Press. 
Harriss, John, Janet Hunter, and Colin M. Lewis. 1995. "Development and Significance of NIE." In The New Institutional Economics and Third World Development, ed. John Harriss, Janet Hunter, and Colin M. Lewis, 1-13. New York: Routledge.

Hoff, Karla and Joseph E. Stiglitz. 2004. After the Big Bang? Obstacles to the Emergence of the Rule of Law in Post-communist Societies. American Economic Review 94 (3): 753-763.

Hupchick, Dennis. 2002. The Balkans: From Constantinople to Communism. New York: Palgrave.

Inalcik, Halil. 1941. Tanzimat nedir? Ankara Dil ve Tarih Cografya Fakültesi Ylllık Çalişmaları Dergisi. Tarih Araştırmaları Cildi: 237-263.

Inalcik, Halil. 1969. Capital Formation in the Ottoman Empire. The Journal of Economic History. 29 (1): 97-140.

Inalcik, Halil. 1972. "The Ottoman Decline and its Effects on the Reaya." In Aspects of the Balkans: continuity and change. Contributions to the International Balkan Conference held at UCLA, October 23-28, 1969, ed. Hendrik Birnbaum and Speros Vryonis Jr., 338354. The Hague: Mouton.

Inalcik, Halil. 1973/1989. The Ottoman Empire: The Classical Age, 1300-1600. Translated by Norman Itzkowitz and Colin Imber. Repr. New Rochelle, N.Y.: Aristide D. Caratzas/Orpheus.

Inalcik, Halil. 1942/1992. Tanzimat ve Bulgar Meselesi. Repr. Istanbul: Eren.

Inalcik, Halil. 1994. The Ottoman State: Economy and Society, 1300-1600. In An Economic and Social History of the Ottoman Empire 1300-1914, ed. Halil Inalcik and Donald Quataert, 11-187. Cambridge: Cambridge University Press.

Jütting, Johannes. 2003. Institutions and Development: A Critical Review. OECD Working Paper No. 210: OECD Development Centre Research Programme on Social Institutions and Dialogue.

Katsarkova, Vera. 2001. Agrarniat prevrat v Severna B"'lgaria (1878-1885). In Izsledvania $v$ chest na chl.-kor. Profesor Srashimir Dimitrov, II, 582-598. Sofia: Akademichno Izdatelstvo Prof. Marin Drinov.

Khristov, Khristo. 1973. Za samoupravlenieto na B'lgarite v Osmanskata d"rzhava prez XV-XVIII v. Istoricheski Pregled no. 1:18-42.

Khristov, Khristo. 1976. Agrarniyat v"pros v B"lgarskata natsionalna revolyutsiya. Sofia: Izdatelstvo na B"'garskata akademiya na naukite. 
Klein, Peter G. 2000. "New Institutional Economics." In Encyclopedia of Law and Economics, Volume I. The History and Methodology of Law and Economics, ed. Boudewijn Bouckeart and Gerrit de Geest, 456-489. Cheltenham, UK: Edward Elgar.

Knack, Stephen, and Philip Keefer. 1995. Institutions and Economic Performance: Crosscountry Test Using Alternative Institutional Methods. Economics and Politics 7 (3): 207227.

Knack, Stephen and Philip Keefer. 1997. Why Don't Poor Countries Catch-Up? A CrossNational Test of an Institutional Explanation. Economic Inquiry 35 (3): 590-602.

Konobeev, Vasiliy D. 1971. Za agrarnata programa na B"'lgarskite revolyutsioneri prez 60-70te godini na XIX B. Istoricheski Pregled. 3:19-48.

Kopeva, Diana and Nivelin Noev. 2001. "Aspects of Land Consolidation after the Land Reform." In The New Structure of the Rural Economy of Post-communist Countries, ed. Osamu Ieda, 123-159. Sapporo: Hokkaido University.

Lampe, John R. 1989. "Imperial Borderlands or Capitalist Periphery? Redefining Balkan Backwardness, 1520-1914." In The Origins of Backwardness in Eastern Europe: Economics and Politics from the Middle Ages until the Early Twentieth Century, ed. Daniel Chirot, 177-209. Berkley: University of California Press.

Lampe, John R. and Marvin R. Jackson. 1982. Balkan Economic History, 1550-1950: From Imperial Borderlands to Developing Nations. Bloomington: Indiana University Press.

Lanjouw, Jean O. and Philip I. Levy. 2002. Untitled: A study of Formal and Informal Property Rights in Urban Ecuador. The Economic Journal 112 (482): 986 - 1019.

Lerman, Zvi. 2002. Productivity and Efficiency of Individual Farms in Poland: A Case for Land Consolidation. Paper presented at the Annual Meeting of the American Agricultural Economics Association, July 28-31 in Long Beach, CA.

Levmore, Saul. 2002. Two Stories about the Evolution of Property Rights. Journal of Legal Studies 31 (2): S421-S451.

Libecap, Gary D. 1986. Property Rights in Economic History: Implications for Research. Explorations in Economic History 23 (3): 227-252.

Libecap, Gary. 1989. Distributional Issues in Contracting for Property Rights. Journal of Institutional and Theoretical Economics 145 (1): 6-24.

Libecap, Gary. 2003. "Contracting for Property Rights." In Property Rights: Cooperation, Conflict, and Law, ed. Terry L. Anderson and Fred S. McChesney, 142167. Princeton: Princeton University Press. 
MacDermott, Mercia. 1962. A History of Bulgaria: 1393-1885. London: George Allen and Unwin.

McGowan, Bruce. 1981. Economic Life in Ottoman Europe: Taxation, trade and the struggle for land, 1600-1800. Cambridge: Cambridge University Press.

McIntyre, Robert J. Bulgaria: Politics, Economics and Society. London: Pinter.

Merrill, Thomas W. 2002. Introduction: The Demsetz Thesis and the Evolution of Property Rights. Journal of Legal Studies 31 (2): S331-S338.

Migot-Adholla, Shem, Peter Hazell, Benoît Blarel and Frank Place. 1991. Indigenous Land Rights Systems in Sub-Saharan Africa: A Constraint on Productivity? World Bank Economic Review 5 (2): 155-175.

Milkova, Fani G. 1970. Pozemlenata sobstvenost v B'lgarskite zemi prez XIX Bek. Sofia: D"rzhavno izdatelstvo nauka i izkustvo.

North, Douglass C. 1981. Structure and Change in Economic History. New York: Norton.

North, Douglass C. 1990. Institutions, Institutional Change and Economic Performance. Cambridge: Cambridge University Press.

North, Douglass C. 1995. "The New Institutional Economics and Third World Development." In The New Institutional Economics and Third World Development, ed. John Harriss, Janet Hunter and Colin M. Lewis, 17-26. New York: Routledge.

North, Douglass C., and Barry R. Weingast. 1989. Constitutions and commitment: The evolution of institutions governing public choice in seventeenth-century England. The Journal of Economic History 49 (4): 803-832.

North, Douglass C. and Robert P. Thomas. 1973. The Rise of the Western World: A New Economic History. Cambridge: Cambridge University Press.

Olson, Mancur. 1965. The Logic of Collective Action. Cambridge, MA: Harvard University Press.

Ostrom, Elinor. 1990. Governing the Commons: The Evolution of Institutions for Collective Action. Cambridge: Cambridge University Press.

Otsuka, Keijiro and Frank Place. 2001. Land Tenure and Natural Resource Management: A Comparative Study of Agrarian Communities in Asia and Africa. Baltimore: Johns Hopkins University Press. 
Palairet, Michael. 1997. The Balkan Economies c. 1800-1914: Evolution without Development. Cambridge: Cambridge University Press.

Pamuk, Şevket. 1987. The Ottoman Empire and European Capitalism 1820-1913: Trade, Investment and Production. Cambridge: Cambridge University Press.

Pamuk, Şevket. 2000. A Monetary History of the Ottoman Empire. Cambridge: Cambridge University Press.

Pantev, Andrei. 1996. "The Historic Road of the Third Bulgarian State." In Bulgaria in a Time of Change: Economic and Political Dimensions, ed. Iliana Zloch-Christy, 1-19. Aldershot, UK: Avebury Ashgate.

Pettengil, John S. 1979. The Impact of Military Technology on European Income Distribution. Journal of Interdisciplinary History 10 (2): 201-225.

Pipes, Richard. 2000. Property and Freedom. New York: Vintage Books.

Place, Frank and Peter Hazell. 1993. Productivity Effects of Indigenous Land Tenure Systems in Sub-Saharan Africa. American Journal of Agricultural Economics 75 (1): 1019.

Popov, Vladimir. 2000. Shock Therapy versus Gradualism: The End of the Debate (Explaining the Magnitude of the Transformational Recession). Comparative Economic Studies 42 (1): 1-57.

Quataert, Donald. 1994. The Age of the Reforms: 1812-1914. In An Economic and Social History of the Ottoman Empire, 1300-1914, ed. Halil Inalcik and Donald Quataert, 761-943. Cambridge: Cambridge University Press.

Quataert, Donald. 2005. The Ottoman Empire, 1700-1922. Cambridge: Cambridge University Press.

Rodrik, Dani. 1999. Where Did All the Growth Go? External Shocks, Social Conflict, and Growth Collapses. Journal of Economic Growth 4 (4): 385-412.

Rodrik, Dani. 2000. Institutions for High-Quality Growth: What They Are and How to Acquire Them. CEPR Discussion Paper No. 2370. London: Centre for Economic Policy Research. http://www.cepr.org/pubs/dps/DP2370.asp

Rodrik, Dani and Arvind Subramanian. 2003. The Primacy of Institutions (and what this does and does not mean). Finance \& Development 40 (2): 31-34.

Rodrik, Dani, Arvind Subramanian, and Francesco Trebbi. 2004. Institutions Rule: The Primacy of Institutions over Geography and Integration in Economic Development. Journal of Economic Growth 9 (2): 131-164. 
Roth, Michael and Dwight Haase. 1998. Land Tenure Security and Agricultural Performance in Southern Africa. Land Tenure Center. Madison, WI: Basis. http://www.ies.wisc.edu/ltc/live/bassaf9806a.pdf

Sened, Itai. 1997. The Political Institution of Private Property. Cambridge: Cambridge University Press.

Sjaastad, Espen and Daniel W. Bromley. 1997. Indigenous Land Rights in Sub-Saharan Africa: Appropriation, Security and Investment Demand. World Development 25 (4): $549-562$.

Sowards, Steven W. 1996a. "Lecture No. 2: 'Asia begins at the Landstrasse:' Comparing Eastern European and European histories." In Twenty-Five Lectures on Modern Balkan History. East Lansing, MI: Michigan State University Libraries.

http://www.lib.msu.edu/sowards/balkan/lecture2.html

Sowards, Steven W. 1996b. "Lecture 3: The principles of Ottoman rule in the Balkans." In Twenty-Five Lectures on Modern Balkan History. East Lansing, MI: Michigan State University Libraries. http:/www.lib.msu.edu/sowards/balkan/lecture3.html

Spulber, Nicholas. 1963. "Changes in the Economic Structures of the Balkans, 18601960." In The Balkans in Transition: Essays on the Development of Balkan Life and Politics since the Eighteenth Century, ed. Barbara Jelavich and Charles Jelavich, 346375. Berkley: University of California Press.

Stavrianos, Leften S. 2000. The Balkans since 1453. New York: New York University Press.

Stoianovich, Traian. 1953. Land Tenure and Related Sectors of the Balkan Economy, 1600-1800. The Journal of Economic History. 13 (4): 398-411.

Stoianovich, Traian. 1976. "Balkan Peasants and Landlords and the Ottoman State: Familial Economy, Market Economy and Modernization." Balkanistica Supplementary Issue: 163-204. Sofia: Instutut za balkanistika.

Streeck, Wolfgang and Kathleen Thelen. 2005. Beyond Continuity: Institutional Change in Advanced Political Economies. Oxford: Oxford University Press.

Strezov, G. 1913. Agraniyat v"pros i pozemlenata sobstvenost v Nova B"lgariya. Sofia: Pechatnitsa Sv. Sofia.

Svejnar, Jan. 2002. Transition Economies: Performance and Challenges. The Journal of Economic Perspectives 16 (1): 3-28.

Thompson, Sarahelen. 1993. Agrarian Reform in Eastern Europe Following World War I: Motives and Outcomes. American Journal of Agricultural Economics 75 (3): 840-844. 
Todorov, Nikolay and Stefan Tsonev. 1981. "Ikonomicheskoto razvitie na B"lgarskite zemi prez poslednite desetiletiya do Osvobozhdenieto ot osmansko vladichestvo." In Stopanska istoriya na B"lgariya 681-1981, ed. Dimit"r Angelov, Nikolay Todorov, Bistra Tsvetkova, Stefan Tsonev, Lyuben Berov, Velizar Velkov, Lalyu Radulov, Georgi Petrov, Dimit"r Vasilev, Stefan Tsankov, Tasho Pachev, Mito Isusov, Gatyu Gatev, Radi Radev, and David Koen, 180-214. Sofia: D"rzhavno izdatelstvo nauka i izkustvo.

Todorova, Maria. 1976. "The Europeanization of the Ruling Elite of the Ottoman Empire during the Period of Reforms." Balkanistica Supplementary Issue: 103-112. Sofia: Instutut za balkanistika.

Todorova, Maria. 2002. Balkanskoto Semeystvo: Istoricheska demografiya na B"lgarskoto obshchestvo prez osmanskiya period. Sofia: Amicitia.

Toshev, Dako Iv. 1937. Razpredelenieto i komasatsiyata na zemite v B"lgariya. Sofia: Ministertsvo na zemedelieto i d"rzhavnite imoti.

Toye, John. 1995. "The New Institutional Economics and its Implications for Development Theory." In The New Institutional Economics and Third World Development, ed. John Harriss, Janet Hunter, and Colin M. Lewis, 49-68. New York: Routledge

Tsankova-Petkova, Genoveva. 1964. Za agrarnite otnosheniya v srednovekovna $B$ "lgariya (XI-XIII B.). Sofia: Izdatelstvo na B"lgarskata akademiya na naukite.

Tsvetkova, Bistra A. 1971. Promeni v Osmanskiya feodaliz"m na Balkanskite zemi prez XVI-XVIII B. Istoricheski Pregled 3:55-73.

Tsonev, Stefan. 1948. V"znikvane i oformyavane na feodalizma v B"lgariya kato gospodstvuvashcha obshchestveno-ikonomicheska formatsiya. Varna: Universitetska pechatnitsa.

Gandev, Khristo and G"1'b G"l"bov, eds. 1959. Turski izvori za B"'lgarskata istoriya, Tom I. Sofia.

V'lchanov, Denyu. 1954. Istoriya na pozemlenite otnosheniya i zemeustroystvoto. Sofia: D"rzhavno izdatelstvo nauka i izkustvo.

V'lchev, Nikola. 1999. Agrarnata struktura na B"lgarskoto zemedelie. Sofia: Gorekspres.

Williamson, Oliver E. 1975. Markets and Hierarchies: Analysis and Anti-Trust Implications: A Study in the Economics of Internal Organization. New York: Free Press.

Williamson, Oliver E. 1979. Transaction-Cost Economics: The Governance of Contractual Relations. Journal of Law and Economics 22 (2): 233-261. 
Williamson, Oliver. 1985. The Economic Institutions of Capitalism: Firms, Markets, Relational Contracting. New York: The Free Press.

Williamson, Oliver. 1994. The Institutions and Governance of Economic Development and Reform. Proceedings of the World Bank Annual Conference on Development Economics, 171-208. Washington D. C.: The World Bank.

Wyman, Katrina M. 2005. From Fur to Fish: Reconsidering the Evolution of Private Property. New York University Journal of Law Review 80 (1), NYU102: 117-240.

Yeager, Timothy J. 1998. Institutions, Transition Economies, and Economic Development. Boulder: Westview Press.

Zukin, Sharon and Paul DiMaggio. 1990. "Introduction." In Structures of Capital: The Social Organization of the Economy, ed. Sharon Zukin and Paul DiMaggio, 1-36. Cambridge: Cambridge University Press. 


\section{Essay II}

Land Fragmentation and its Relation to Land Productivity 


\section{Introduction}

Land fragmentation, commonly defined as the situation where a farm is composed of more than one separate plot of land, has been identified as a major outcome of the Bulgarian land reform initiated at the outset of the transition from a centrally planned to a market economy. The fragmentation of agricultural land holdings in Bulgaria is widely believed to be one of the major causes of poor farming practices, low levels of agricultural productivity and inefficient uses of land and other agricultural resources. ${ }^{83}$ Moreover, fragmentation is seen as an obstacle to the development of efficient land markets. In response to the perceived disadvantages of land fragmentation, the Bulgarian Ministry of Agriculture and Food Supply ${ }^{84}$ (MAFS) initiated a number of projects to assess farmers' willingness to consolidate their agricultural land and to develop policies for farm land consolidation (MAFS Annual Agricultural Report 2004, 22-27). ${ }^{85}$

To date, however those promoting land consolidation - including MAFS, other agricultural institutions and organizations, and independent scholars - have not provided solid evidence documenting the negative effects of land fragmentation on agricultural productivity in the country. It seems that the initiatives for the development of

\footnotetext{
${ }^{83}$ Almost all studies and documents referring to or discussing the problems in Bulgarian agriculture mention fragmentation as one of the major obstacles to the efficient use of land and other agricultural resources. Examples include the Annual Reports of the Ministry of Agriculture, the Bulgaria Rural Development Programme (2007-2013) of the European Union's European Agricultural Fund for Rural Development, Rembold (2003), V'lchev (1999), Van Dijk (2003), Van Dijk and Kopeva (2006), Risina and Mladenova (2002), Noev, Swinnen, and Vranken (2004), and others. However, land fragmentation is viewed or treated by these studies as an issue inseparable from the issue of the division of land in Bulgaria into small farms.

${ }^{84}$ MAFS was formerly (until September 2007) known as the Ministry of Agriculture and Forestry.

${ }^{85}$ These initiatives have been supported by the World Bank, the Food and Agriculture Organization of the United Nations, and the European Union.
} 
consolidation policies in Bulgaria are based on the widely-accepted assumption that fragmentation inevitably causes agricultural inefficiencies. The absence of such evidence is the motivation for this essay. The goal here is to use multiple regression analysis to examine and analyze the relationship between land fragmentation and land productivity.

It is necessary to emphasize that the essay is concerned primarily with the phenomenon of fragmentation, not the phenomenon of small farm size. ${ }^{86}$ The majority of the literature on land fragmentation in Bulgaria treats the issue of fragmentation along with or as inseparable from the issue of the prevalence of small-sized farms or parcels in the country. According to the definition adopted here, a farm consisting of one small plot is not fragmented. Even though the two issues may or may not be related, they are nonetheless different. They need to be defined, examined, and analyzed separately in order to determine the precise impact of each.$^{87}$ Therefore, another goal of this essay is to draw attention to the need to distinguish between and address separately the issue of fragmentation and the issue of undersized farms.

\footnotetext{
${ }^{86}$ As clearly stated in the next section and following the most frequently used definition, land fragmentation refers to "the type of land ownership pattern where a single farm consists of numerous discrete parcels often scattered over a wide area" (Binns 1950, 5 quoted in Bentley (1987)).

${ }^{87}$ For example, many households may prefer to hold un-fragmented small-sized farms either for subsistence farming or for the purposes of consuming organically grown food. This may or may not be the most efficient way of using land but it can nonetheless be desired by landholders. On the other hand, regardless of being fragmented or not, bigger farms may be desired, particularly by governments, because, for example, they allow for mechanized farming. Furthermore, land consolidation could be applied by combining small farms even if there is no fragmentation at all. In any case, however, it is not helpful to mix the issue of fragmentation with the issue of small farm size as is frequently the case in the literature on Bulgarian fragmentation.
} 
The essay is organized as follows. Section II reviews the literature on land fragmentation; section III describes the methodology; section IV presents, explains and describes the data; section V discusses the results; and section VI concludes. 


\section{Literature Review}

\section{1 Background}

Land fragmentation is most often defined as "the type of land ownership pattern where a single farm consists of numerous discrete parcels, often scattered over a wide area" (Bentley 1987). ${ }^{88}$ Following Blarel et al. (1992) the definition can be simplified as the situation in which "a household operates more than one separate parcel of land." The term "land fragmentation" is also known as parcellization, subdivision, scattering, pulverization, and morcellement of plots (Bentley 1987, Sengupta 2006). ${ }^{89}$

As King and Burton (1982) indicate and as will be seen in the review of some of the sources in this section, fragmentation "is often taken to imply the subdivision of farm property into undersized units which are too small for rational exploitation." Such a conceptualization of fragmentation creates confusion by differentiating the issue of having small-sized farms or small-sized plots from the issue of having farms composed of several plots, regardless of their size. To avoid any confusion of fragmentation with the phenomenon of division of land into small farms, the discussion below will use the term, focus on, and assess fragmentation strictly in the sense put forward by Bentley and Blarel et al. As suggested by King and Burton, the issue of undersized farms is one of different and wider implications and therefore, is beyond the scope of the essay.

\footnotetext{
${ }^{88}$ Like many others, Bentley uses the definition of Binns $(1950,5)$ and provides a discussion based on that definition. However, as noted by Bentley, it is possible, although not very common, to define fragmentation as "the division of land into small farms" and analyze fragmentation within that definition.

${ }^{89}$ Throughout the essay the terms 'parcel' and 'plot' will be used interchangeably.
} 
Land fragmentation is documented as a universal characteristic of both primitive and modern agricultural systems throughout the world - it can be "found on all continents, among farming systems of all types, and on farms of all sizes" (Sengupta 2006).$^{90}$ It is not only closely associated with Europe ${ }^{91}$ but also appears to be a common and important feature of the agricultural systems in the United States and Canada (Bentley 1987, King and Burton 1982); in many developing and least developed countries (Bentley 1987; Blarel et al. 1992; Igbozurike 1970; Jabarin and Epplin 1994; Jha, Nagarajan, and Prasanna 2005; King and Burton 1982; Sengupta 2006); in the transitional and other economies of Asia (Heston and Kumar 1983; Hung, MacAulay, and Marsh 2007; Nguyen, Cheng, and Findlay 1996; Tan, Qu, and Heerink 2005); in the Central and Eastern European economies in transition and in the Commonwealth of Independent States (Lerman 2005; Rembold 2003; Sabates-Wheeler 2002, 2005; Thomas 2006; Van Dijk 2003; Van Dijk and Kopeva 2006).

Land fragmentation is considered an important agricultural land tenure issue for it is believed to give rise to farm inefficiencies, particularly to inefficient use of land, labour, capital, and other resources. For example, inefficient use of land results when cultivable land is used for roadways and fences between parcels; inefficient use of labour results when time is spent in traveling to and from scattered parcels; inefficient use of capital occurs as a result of increased transportation costs for machinery, equipment, and for

\footnotetext{
${ }^{90}$ For an extensive list of countries where the existence of fragmentation is documented in various historical periods refer to Bentley (1987) and King and Burton (1982).

${ }^{1}$ As Bentley (1987) notes, fragmentation was considered a problem in all of Western Europe with the exception of the UK and some parts of Scandinavia. In those countries, fragmentation was still present but to a lesser degree compared to the rest of Europe.
} 
various other inputs and outputs of production activities. ${ }^{92}$ Furthermore, fragmentation can be the cause of negative externalities such as reduced scope for irrigation (Blarel et al. 1992; King and Burton 1982). The eventual outcome of fragmentation can therefore be lower productivity and higher input costs.

Because it has been widely criticized in the academic literature and by agricultural policymakers, the persistence of land fragmentation has been considered as a major problem of developing and transitional agricultural systems. ${ }^{93}$ Not surprisingly, therefore, international organizations such as the Food and Agriculture Organization of the United Nations (FAO), the World Bank, the European Union (EU), and most governments have been widely promoting, supporting and assisting land consolidation policies as important components of land reform programs in these countries. Land consolidation is defined by King and Burton (1983) as "the process whereby landowners and tenants are persuaded or compelled to surrender their scattered plots in order to receive an equivalent area or value of land in one or a few compact blocks." In the FAO Land Tenure Studies (2003, 19), however, it is asserted that the interpretation of land consolidation as a simple policy response to fragmentation is incorrect. It is argued that in addition to the reallocation of parcels, land consolidation policies aim at broader social and economic reforms for rural

\footnotetext{
${ }^{92}$ For a review of the economic and social costs associated with fragmentation and various other disadvantages of fragmentation refer to King and Burton (1982).

${ }^{93}$ For example, Bentley (1987) refers to the following description of fragmentation by agricultural policymakers, which is quoted in various sources cited by Bentley: "[fragmentation is] the blackest of evils, to be prevented by legislative action as one would attempt to prevent prostitution or blackmail." Furthermore, Rembold (2003) argues that, despite the remarkable success of land reforms in the former socialist countries, land fragmentation emerged as a side-effect with detrimental implications for private and public investments, sustainable economic growth and social development.
} 
development. ${ }^{94}$ Moreover, consolidation might mean de-fragmentation but it also might mean the combination of small un-fragmented farms.

Nevertheless, the long history and persistence of fragmentation, the fact that farmers are often reluctant to consolidate their holdings either voluntarily or when incentives are provided, raises the possibility that there might exist economic, social, traditional, or other rationales for fragmentation (Bentley 1987, Blarel et al. 1992; Igbozurike 1970; Johnson $1970^{95}$; King and Burton 1982; Sengupta 2006). Indeed, a careful review of the studies on land fragmentation discussed below reveals a number of rationales for the existence and persistence of land fragmentation. ${ }^{96}$ Most importantly, a number of empirical studies report both negative and positive impacts of land fragmentation on productivity, investment, efficiency, and other economic outcomes. Moreover, there does not seem to be sufficient empirical evidence to suggest that the consolidation of land holdings is necessarily a good solution to problems in agriculture or land tenure. ${ }^{97}$ Given the high costs but uncertain benefits of land consolidation, its wide promotion does not seem to be as yet justified (Bentley 1987; Sengupta 2006). The observation of Bentley, twenty years ago, that "governments have been eager to attempt consolidation schemes but unwilling to study farm fragmentation" seems to still hold today. In order to better

\footnotetext{
${ }^{94}$ These broader reforms include village renewal, support to community-based agro-processing, construction of rural roads, construction and rehabilitation of irrigation and drainage systems, erosion control measures, environmental protection and improvements including the designation of nature reserves, and the creation of social infrastructure including sports grounds and other public facilities (FAO 2003, 19).

${ }_{95}$ Cited in Bentley (1987).

${ }^{96}$ Among the better and more comprehensive inquiries concerning the rationale and economic motivation for land fragmentation are the influential works of McCloskey (1975a, 1975b), followed by Fenoaltea (1976), Dahlman (1980), Heston and Kumar (1983), McPherson (1983), Blarel et al. (1992) and others.

${ }^{97}$ For a review of unsuccessful consolidation programmes refer to King and Burton (1982, 1983).
} 
understand fragmentation, there is a need for more careful and systematic assessment of its causes, impacts, benefits and costs on a case by case and country by country basis.

\section{2 Measures of Land Fragmentation}

In general, a farm is described as consolidated when it is composed of just one plot of land; a fragmented farm, on the other hand, is a farm which consists of more than one plot (Simmons 1964). A major problem in relation to studying or assessing land fragmentation is the lack of a consensus on a standard objective measure of the degree of fragmentation (Bentley 1987; Blarel et al. 1992; Hung, MacAulay, and Marsh 2007; King and Burton 1982). This leads to confusions and difficulties in (1) determining whether or when farms are 'too fragmented'; (2) defining the criteria for the need of consolidation; and (3) comparing land fragmentation and its impacts across countries (Bentley 1987).

Given that fragmentation is concerned with the organization of farms in location and space, King and Burton (1982) identify six characteristics of plots as the parameters desirable in assessing the degree of land fragmentation: (1) the farm size; (2) the number of plots; (3) the size of plots; (4) the size distribution of plots; (5) the spatial distribution of plots; and (6) the shape characteristics of plots. However, the fragmentation index measures developed so far do not incorporate all of these parameters; rather, they measure at most three of them. The most often used measures and indices of fragmentation defined across a large geographic area such as a province or country can be described as follows: 
1. Number of Plots per Farm. This is the simplest, and perhaps most often used, measure derived from the definition of fragmentation. It takes into account only the number of plots of which a farm is composed. The higher the number of plots, the higher is the level of fragmentation. In the case of Bulgaria, for example, many sources provide a simple national average of the number of plots per farm together with average plot and farm size.

2. The Simmons Index. This index of fragmentation is formulated by Simmons (1964) as follows:

\section{F.I. (Fragmentation Index $)=\sum \mathbf{a}^{2} / \mathbf{A}^{2}$}

The Simmons Index can better be expressed as F.I. $=\sum \mathrm{a}_{\mathrm{i}}{ }^{2} / \mathrm{A}^{2}$ where $\mathrm{i}=1, \ldots, \mathrm{n} ; \mathrm{a}_{\mathrm{i}}$ is the area of the $i^{\text {th }}$ plot of a farm; $\mathrm{n}$ is the total number of plots a farm is composed of; and A is the total area of a farm. ${ }^{98}$ The index is calculated for each farm and as the formula implies, it expresses the relationship between the number of plots comprising a farm and the relative sizes of these plots; also, the index is independent of total farm size. ${ }^{99}$ It is obvious then that the Simmons Index takes into account three of the above mentioned parameters: the number of plots, the size of plots, and the total farm size. The maximum value that the Simmons Index can take is 1 , which is attained when the farm is consolidated, that is, when it is composed of one single plot. As the number of plots increases, the value of the index approaches zero, indicating a high level of fragmentation.

\footnotetext{
${ }^{98}$ Simmons (1964) uses the term 'block' instead of 'plot'. The index is an adaptation of the Herfindahl's Index which is developed for the study of concentration in the United States' steel industry.

${ }_{99}$ As explained by Simmons (1964), to maintain the relative order of importance of each size of plot to the others within a farm's total acreage, the size of each plot is weighted by the method of squaring.
} 
3. The Simpson Index. ${ }^{100}$ Introduced by Blarel et al. (1992), the Simpson Index has properties identical to the Simmons Index since it is formulated as 1 - the Simmons Index:

$$
\text { Simpson Index }=1-\sum \mathbf{a}^{2} / \mathrm{A}^{2}
$$

Therefore, the Simpson Index takes the value of zero when the farm is consolidated, that is, when it is composed of one single plot. As the number of plots increases, the value of the index approaches one, indicating a high level of fragmentation.

4. The Januszewski Index. Developed by Januszewski (1968), this index defines the degree of consolidation of a farm and is formulated as follows ${ }^{101}$ :

$$
\mathbf{K}=\left(\sqrt{ } \sum \mathbf{a}\right) /\left(\sum \sqrt{ } \mathbf{a}\right)
$$

The Januszewski Index, in which ' $a$ ' stands for the size of plots, is similar to the Simmons Index in the sense that it accounts for the same three parameters: the total farm size, the number of plots, and the size of plots. Moreover, just like the Simmons Index, the Januszewski Index is independent of the size of the farm. As explained by Januszewski (1968) the index has three properties: (1) an increase in the number of plots leads to a decrease in $\mathrm{K}$, the index of consolidation, implying an increase in the level of fragmentation; (2) as the size of plots approaches the same value (the range of plot sizes is small) the index decreases, meaning that fragmentation increases; and (3) as the area of big plots increases and that of small plots decreases (and visa versa) the index increases, meaning that fragmentation decreases.

\footnotetext{
${ }^{100}$ The study which develops this index could not be located. It seems to be first introduced by Blarel et al. While there are studies which use the index following Blarel et al., there does not seem to be any which used the index before them.

${ }^{101}$ In the formulation of this index Januszewski (1968) uses the arithmetical rule which states that the square root of a sum of numbers is smaller than the sum of their square roots.
} 
Both Simmons (1964) and Januszewski (1968) suggest empirical evidence that there is a relation between the farm size and the degree of fragmentation: an increase in farm size is accompanied by an increase in the degree of fragmentation. This finding is somewhat in contrast with the general concern that decrease in average farm size is accompanied by or results from an increase in fragmentation.

Other, less often used, indices include those developed by Igbozurike (1974) and Schmook (1976). Failing to incorporate the number of plots, the Igbozurike Index expresses a relationship between the average size of plots and the distance traveled while visiting all plots. According to King and Burton (1982) this index creates some inconsistencies in measuring the distances between plots. The Schmook Index incorporates farm size and distance but ignores the number of plots. ${ }^{102}$ Two more sophisticated measures of fragmentation have been proposed recently by Gonzalez, Alvarez, and Crecente (2004) and Gonzalez, Marey, and Alvarez (2007). The Combined Size and Shape Index proposed in the former study takes into account plot size and shape $^{103}$ and the measure in the latter accounts for dispersion of plots in addition to plot size and shape. ${ }^{104}$

In conclusion, none of the indices incorporates all six parameters suggested by King and Burton (1982). In addition, none of the indices can be described as 'mostly preferred' in

\footnotetext{
${ }^{102}$ For a more detailed discussion of these and other indices refer to Bentley (1987) and King and Burton (1982).

${ }^{103}$ This index takes into account plot shape which is important in terms of having influence on the efficiency of operations on that plot (Bentley 1987; Gonzalez, Alvarez, and Crecente 2004). The index, on the other hand, ignores distance between plots or distance between household and plots.

${ }^{104}$ This seems to be the first index taking into account dispersion of plots.
} 
studies; in the economics literature, the Simmons, Simpson, and Januszewski indices seem to be commonly used.

\section{3 Measures of Land Fragmentation in Bulgaria}

Sources discussing the issue of land fragmentation in Bulgaria before collectivization of land under the communist regime rely on data from the agricultural censuses conducted in $1897,1908,1926$, and 1934. As will be discussed below, while most sources referring to the emergence of land fragmentation in the beginning of the $20^{\text {th }}$ century are concerned primarily with the division of land into small parcels in general, there are some which point to the problem of farms composed of too many parcels (Brown 1970, 196; Howe 1998, 210; Meurs 2001, 30; Pantev 1996, 11). ${ }^{105}$ The prevalence of small farm and plot sizes, combined with the national average of parcels per farm are often used as indicators of fragmentation in Bulgaria.

Table 1 (Data Appendix for Essay II) shows the data on distribution of land in Bulgaria collected during the Bulgarian agricultural censuses of 1897 and 1908; Table 2 shows the data for 1926 and 1934. From these data, the only way to measure fragmentation, as defined in this section, is to calculate the national average of parcels per farm or holding, which is exactly what some sources do. ${ }^{106}$ To have a slightly better idea about the number

\footnotetext{
${ }^{105}$ Brown notes that in 1934 the number of Bulgaria's small farms was 884,869 and they were composed of $11,862,158$ scattered, separate plots. Pointing to the 1.1 million private farms averaging 4.3 hectares per holding and fragmented into 12 million individual plots, Howe notes that between 1908 and 1946 individual land holdings became increasingly fragmented and geographically dispersed in many small plots. Pantev indicates that in most cases landholdings were small and unconsolidated, divided into ten or more scattered plots. Meurs estimates that in 1946 each family's farm was composed on average of 17 tiny plots scattered around the village.

${ }^{106}$ The average number of parcels per farm is calculated by dividing the total number of parcels by the total number of farms.
} 
of parcels per farm, in this study the average number of parcels per farm in each farm size range was calculated.

The data show evidence of fragmentation: in 1897 the overall average number of parcels per farm was 10; the lowest average is 1.5 parcels for farms below 5 decares and the highest is 38 for farms in the $2000-3000$ decares size range. In 1908 the overall average number of parcels per farm increases to 11 with the lowest subgroup average being 3 parcels for farms ranging from 5 to 10 decares and the highest being 46 for farms both in the 2000-3000 and above 5000 decares range. In 1926 the overall average number of parcels per farm rises to 15 with the lowest average of 3 parcels per farm for farms of sizes less than 10 decares and the highest average of 37 for farms of sizes greater than 500 decares. Finally, in 1934 the overall average number of parcels per farm decreases to 13; moreover, there is a general decrease, compared to previous years, in the average number of parcels per farm for farms in all size ranges; the lowest average remains 3 for farms as big as or below 10 decares and the highest average drops to 32 for farms larger than 500 decares.

Data illustrate the overwhelming prevalence of small independent landholders and the egalitarian distribution of land following the liberation from Ottoman rule in 1878 , discussed in Section V of Essay I. Since 1897 is the year of the first agricultural census in Bulgaria, it seems impossible to compare the 1897 distribution of farms to that of earlier periods. Often this distribution is closely or mostly associated with the disintegration of large estates after liberation from Ottoman rule. In the subsequent subsections it will be 
demonstrated that land distribution in 1897 was very similar to that in the $1870 \mathrm{~s}$, which is before liberation. Generally, it is believed that subdivision of land into more parcels (due to partible inheritance, for example) leads to fragmentation. Table 3 suggests that this is not always true in the case of Bulgaria.

Table 3 shows the percentage changes in the number of holdings; the number of parcels; and the number of average parcels per farm between the periods 1897 to $1908 ; 1908$ to 1926; and 1926 to 1934 . It can be seen that in the years between 1897 and 1908, the increase in the number of parcels for farms less than 30 decares $^{107}$ is accompanied with a decrease in the average number of parcels per farm and therefore decrease in the level of farm fragmentation. The table shows that during this period the increase in the number of farms went faster than the increase in the number of parcels; therefore, it is not surprising that there is a decrease in fragmentation despite increase in the number of parcels. Furthermore, the percentage increase in the number of parcels larger than 30 decares in the same period is much higher compared to the percentage increase in the average number of parcels per farm. In the period 1908-1926, the number of parcels for farms larger than 150 decares decreases while the average number of parcels slightly increases. Such a situation can only be explained with a decrease in the number of farms larger than 150 decares, which is confirmed with the results in column 2. In the period 1926-1934, while the number of parcels for farms less than 100 decares increases, the corresponding

${ }^{107} 30$ decares is considered the minimum amount of land to provide a livelihood. 
average number of parcels per farm either does not change or decreases. The point being that more parcels, by itself, need not imply more fragmentation. ${ }^{108}$

Based on the above analysis, it can be inferred that division and subdivision of land or parcellization is not always accompanied by increase in the level of fragmentation. In other words, the two do not necessarily go hand in hand as is often assumed. Therefore, as it was emphasized in the introduction of the essay, it is important to differentiate clearly between the two issues.

With regard to present day level of fragmentation, as will be discussed in detail below, many sources are concerned with the overall division or parcellization of land into small farms. For example, in the 2005 Annual Agricultural Report of the MAFS (p. 3-4), fragmentation is measured as the ratio between the area of the agricultural land in each district and the number of parcels in this district which gives the average size of each parcel. As we have seen, small average parcel size need not imply fragmentation; it could be the case that a farm is composed of just one small parcel (in which case the farm is consolidated) so it is necessary to consider the number of farms as well. Other authors provide a valid measure of fragmentation, the average number of parcels per farm. For example, Risina and Mladenova (2002) estimate that most farms are composed on average of four parcels, often scattered in more than one residential area. In a survey of 1400 agricultural households from three different regions in Bulgaria, Noev, Swinnen, and Vranken (2004) find that in 2003, 78.7 percent of farms were composed of more than

\footnotetext{
${ }^{108}$ If we had no fragmentation (all one parcel holdings), and then split each holding in two and gave half away, we would still have no fragmentation and a lot more parcels.
} 
one parcel of land; the average number of parcels per farm was 5.3 with average size of parcels being 6 decares; and 39 percent of surveyed farms were composed of more than 5 parcels.

Furthermore, Kopeva and Noev (2001) indicate that, on the national level, the average number of parcels per farm in 1997/1998 was 2 for small farms, 3 for medium farms, and 2.62 for large farms. The average figures for 1998 provided by Sabates-Wheeler (2002) are 3 to 7 parcels per farm. ${ }^{109}$ However, Kopeva (2002) estimates that, before subdivision between heirs, in 2001 small, medium, and large farms in Bulgaria were composed of 3, 4, and 6 parcels on average, respectively. After subdivision between heirs, this average is estimated to be 5,11 , and 13 parcels for small, medium, and large farms, respectively. ${ }^{110}$ To conclude, although there is some disparity in the estimates, the sources indicate considerable evidence of fragmentation in the present period. However, this approximate level of fragmentation seems to be much lower than that of the pre-1944 period. This is interesting to note, since given that land was restituted to its pre-1944 owners, most would expect, as Kopeva (2002) does, a level of fragmentation close to - or higher than-(due to inheritance) that of the period before 1944.

\section{4 Causes of Land Fragmentation}

Fragmentation can be the result of one or the combination of various socio-cultural, economic, and other factors (Igbozurike 1970; King and Burton 1982). Since the

\footnotetext{
${ }^{109}$ Sabates-Wheeler indicates that the figures for Bulgaria were obtained from Kopeva during a conference discussion in 2002.

${ }^{110}$ Except for Noev, Swinnen, and Vranken (2004) where numbers are calculated for a sample size of 1400 , none of the above sources indicates their method of measurement or estimation.
} 
persistence of fragmentation raises the question of whether it is a situation desired by farmers, Blarel et al. (1992) classify the explanations for its causes into two broad categories: "supply-side" explanations and "demand-side" explanations. This section will use this classification to discuss the possible causes of fragmentation in Bulgaria. Supplyside explanations deal with land fragmentation as an exogenous phenomenon imposed on farmers, whereas demand-side explanations treat land fragmentation as having an endogenous character or as a phenomenon desired and voluntarily chosen by farmers for some presumed benefits.

\section{4.1 Supply-side Explanations}

In general, major factors that fall into the category of supply-side explanations for fragmentation include partible inheritance, population growth, government-initiated land reform policies or existing state laws, and change from common or indigenous property systems to individual ownership. ${ }^{111}$ Each of these factors is discussed below. The overall message of this section is that supply-side factors alone are unlikely to account for the observed degree of fragmentation in Bulgaria today.

\section{4.1.1 Partible Inheritance}

Partible inheritance, which is a typical feature of the inheritance laws under the Common Law and the Napoleonic Code, refers to the custom of inheritance in which land holdings are apportioned between heirs. In contrast, impartible inheritance or primogeniture is the custom in which land holdings are inherited by only one, usually the oldest, heir (Homans

\footnotetext{
${ }^{111}$ For a detailed review of the evidence supporting the role and influence of these factors on the degree of fragmentation in various countries see Bentley (1987) and Blarel et al. (1992).
} 
1937). This factor is considered by many as the most common cause of fragmentation the argument is that if land is divided among children after the death of a landholder, considerable subdivision of land would occur in just a few generations. However, the comprehensive review of Bentley (1987) reveals that the evidence on the influence of partible inheritance on fragmentation is actually mixed. While some authors establish a positive relationship between the two, many others can provide no such evidence. In fact, in some countries, such as in Mexico and France, partible inheritance does not lead to fragmentation while in other countries, including Ireland, fragmentation occurs under impartible inheritance or primogeniture. ${ }^{112}$ These results are not surprising: logically, if a father has three plots and gives one to each son, fragmentation will decline. On the other hand, if the same father decides to divide equally each plot of land, the number of farms will increase to three but the level of fragmentation will not change. The problem is that, other factors being constant, the bivariate partible inheritance/fragmentation relationship does not hold.

Partible inheritance of land and other property is a custom that has operated in Bulgaria at least since the second half of the $9^{\text {th }}$ Century and remained even during Ottoman rule (Todorova 2002, 114-120). A specific characteristic of the custom, however, is that only the male heirs would be entitled to equal inheritance and female heirs would be compensated with dowries (Vladigerov 1942, 31-32). In addition, tradition required that each parcel of land is equally divided between heirs (Toshev 1937, 20). According to the findings of Todorova and Vladigerov, the rationale behind the custom was the desire to

\footnotetext{
${ }^{112}$ For a detailed review of this evidence refer to Bentley (1987), Blarel et al. (1992), King and Burton (1982), and McCloskey (1975a, 102-113).
} 
preserve the divided ownership of land holdings within the family or at least within the village. While the tradition somewhat limited the division of land by excluding females from inheritance, it allowed limitless division among male heirs. The tradition defined no minimum size where division should end (Vladigerov 1942, 40-41). This, according to Vladigerov, had led to progressive parcellization of land, the result being the emergence of nonviable farms. But increased parcellization does not necessarily imply increased fragmentation - if each heir gets one holding of one parcel, parcellization can take place without fragmentation increasing.

Female heirs were recognized as equal only with the inheritance law of 1890 which, essentially, remains in force today. However, in the beginning, the law and its enforcement met the fierce resistance of the public which continued to practice the old tradition. Todorova $(2002,118)$ explains that the law of 1890 was in direct contradiction with the old and long practiced tradition of excluding the females as equal heirs and was therefore difficult to accept. After being widely criticized and boycotted, the law was amended in 1896 and 1906. The 1896 amendment allowed male heirs to buy out the females' share and the 1906 amendment assigned the male heirs a share of inheritance which was double that of the females'. Vladigerov $(1942,41-42)$ points out that, in order to prevent further parcellization, the 1896 amendment also identified a minimum size of parcels under which division would not be allowed. Depending on the crops cultivated on a given field, this minimum size would be in the range between 1 to 3 decares. Nonetheless, Vladigerov believes that despite the 1896 and 1906 amendments, under the 
law of 1890 , the pace of division of land was higher than that under the tradition of apportioning inherited land among male heirs.

It has to be noted here that the above discussion refers mostly to the relationship between partible inheritance and division of land, not necessarily to the relationship between partible inheritance and fragmentation. While it is tempting to assume that there is an inherent relationship between the division of land and fragmentation, it may not necessarily be the case. For example, if a landholder has three sons and owns one plot of land, after his death, the plot will be divided into three equal parts. Each son will, therefore, inherit one plot of land and fragmentation will not emerge despite the division of land. If the landholder had two plots of land, each of the three sons could inherit two plots of land which means that each of the three heirs inherited the level of land fragmentation their father had. The implication of these examples is that the number of parcels per household or per farm might not change; what might change (increase) is the number of households which own two parcels of land. In addition, in the analysis of the data in the previous section it was shown that in the case of Bulgaria increased parcellization did not always lead to increase in fragmentation.

On the other hand, while most sources list partible inheritance as one of the major causes of fragmentation (as defined in this study) in the country, none of them provides empirical evidence or elaborates on the relationship between inheritance patterns and fragmentation. For example, Berov (1981, 374; 1984, 239-240), Bishop et al. (1995, 92), Dräger and Jaksch (2001, 182), Howe (1998, 210), McIntyre (1988, 25), Toshev (1937, 
20), V"lchev $(1999,47,139-145)$, Kopeva $(2000,2001)$ only note that the existence of the custom and law is the major cause for the emergence and persistence of fragmentation in Bulgaria both in the first half of the $20^{\text {th }}$ century and today, implying that this is a logical consequence. However, given the above examples and the evidence questioning the seemingly logical relationship between partible inheritance and fragmentation discussed above, it is impossible to conclude that this relationship exists in the case of Bulgaria. The lack of empirical evidence makes it difficult to determine the degree of impact, if any, of partible inheritance on the level of fragmentation in Bulgaria.

\section{4.1.2 Population Growth}

Logically, increase in the population of those wanting to own land will contribute to an increase in land scarcity. Fragmentation may be the result of increased land scarcity since farmers in need of land may be willing to accept (perhaps most often buy) any additional parcel or parcels of land located reasonably close to his house (Blarel et al. 1992). However, although often listed as a cause of fragmentation, especially in association with partible inheritance, evidence shows that population growth may not necessarily lead to fragmentation (Bentley 1987). Using an econometric model to test for the factors that drive fragmentation in China, Tan, Qu, and Heerink (2005) for example, suggest that "higher population pressure reduces the average plot sizes but does not affect the average number of plots [per farm]." While Blarel et al. find positive but statistically insignificant relationship between population density and the Simpson Index of farm fragmentation across regions in Ghana and Rwanda; they argue that the relation in itself does not prove that fragmentation is a result of higher population density. Just like in the case of partible 
inheritance, the problem is that, other factors being constant, the bivariate population growth/fragmentation relationship does not hold.

Mouzelis (1976) suggests that extreme fragmentation ${ }^{113}$ of peasant holdings in Bulgaria resulted from the spectacular population growth which began in the first half of $19^{\text {th }}$ century. Others point to population growth as the second most important cause of fragmentation after partible inheritance (Berov 1984, 239; Howe 1998, 210, Toshev 1937, 20). Indeed, Lampe and Jackson $(1982,140)$ report that Bulgarian population grew steadily after 1830 . According to their rough estimates, between 1825 and 1875 , the population increased from 1.5 million to 3 million. Ivanov and Tooze (2007) note that between 1892 and 1910, Bulgaria's population expanded from 3.3 million to 4.3 million - an increase of 31 percent in just 18 years and that the rate of growth reached its peak in 1926 at 2 percent per annum.

Furthermore, according to the Statistical Yearbook of the Kingdom of Bulgaria (1935, 15), between 1921 and 1935 population density increased by 25.5 percent, from 47 to 59 people per square kilometre. Estimating that during those years more than 50,000 new households were formed each year, and given that most households were farm households, Toshev $(1937,16)$ suggests that this increased "the hunger for land." Therefore, Toshev (20-21) lists population growth and partible inheritance as the first and second, respectively, most important causes for both the division of land and fragmentation but without further elaborating on this seemingly causal relationship. He

\footnotetext{
${ }^{113}$ Mouzelis, like most of other studies referred to in this section does not clarify his meaning of fragmentation. As mentioned in the introduction, it seems that most scholars perceive fragmentation as the combination of small parcels and numerous parcels per farm.
} 
argues that in the period 1897 to 1908 the overall number of parcels of land increased by 23.7 percent so that in 1908 , farms were composed of 11 parcels on average. ${ }^{114}$ Furthermore, it is calculated that in 1926, the average number of parcels per farm reached 15 , indicating an increase of 36.4 percent in 18 years. ${ }^{115}$ Based on the same data, V'lchev $(1999,4648)$ and Dolinsky (1932) followed a reasoning similar to that of Toshev, and concluded that population growth in Bulgaria led to land fragmentation.

However, the above sources do not take into account the expansion in agricultural land during these years. The comprehensive study of Ivanov and Tooze (2007) suggests that "despite rapid population growth, the endowment of cultivated land per head of rural population actually doubled from the late $1880 \mathrm{~s}$, to reach its peak in 1911 , at just over 0.8 hectare per capita... [and] by the beginning of 1913, sufficient new land could be brought into cultivation every year to stave off any decline in land per capita."116 Similarly, Howe $(1998,209)$ argues that land supply remained more than adequate to match demand due to expropriation of state and communal property, due to the continued emigration of Turks, Greeks and Bulgarians, as well as due to some increase in the number of town dwellers. Ivanov and Tooze point out that this does not suggest that there was abundance of agricultural land ${ }^{117}$ but that land scarcity was not actually increasing, at least not until

\footnotetext{
${ }^{114}$ Toshev uses the estimates provided by Kiril Popoff, the founder and first Director of the Statistical Office of Bulgaria. It is not indicated how the average of 11 parcels per farm was obtained but it seems that Popoff divided the total number of parcels in the country by the total number of farms. Referring to Table 1 , it can be seen that the number of parcels in 1897 is $9,876,519$ and the total number of farms is 799,588 ; accordingly the average number of parcels per farm is 11 .

${ }^{115}$ Although, again, not indicated, the 15 average number of parcels per farm seems to be obtained by dividing the total number of parcels, 11,478, 002 by the total number of farms, 750613 in 1926. Refer to Table 2.

${ }^{116}$ Ivanov and Tooze's arguments are based both on the figures provided by Kiril Popoff who estimates that between 1889 and 1911, the area under cereals increased by 157 percent and on the more credible census figures for and after 1897.

${ }^{117}$ Ivanov and Tooze note that the ratio of rural population to cultivated land in Bulgaria was higher compared to that of North Western Europe.
} 
1913. In fact, they argue that the growth of agricultural output during this period was mainly due to the expansion in land use. The problem of land scarcity seems to arise after 1914 when there was no room for further expansion in land and after 1919 when the country lost 6.81 percent of its cultivated land ${ }^{118}$ but population continued to grow until 1926, leading to a progressive decline in land to labour ratios. However, Ivanov and Tooze indicate that this was a transitional situation since being quick to adapt to changing economic conditions, by 1935, Bulgarian population growth rate was just half of that of 1926 and continued to decline afterwards.

It is difficult to derive implications about the degree of impact of population growth, if there was any, on land fragmentation in Bulgaria. Following the findings of Ivanov and Tooze (2007), until 1914, despite rapid population growth, there was no increase in land scarcity. Therefore, the argument that the increase in fragmentation in the period 1897 to 1908 was mainly due to population growth is not justified. In fact, it can be inferred that, at least until 1914, population growth did not lead to land scarcity and therefore could not be a reason for the increase in fragmentation. In the period between 1914 and 1926 population growth led to land scarcity and fragmentation increased so it is possible that there is a positive relationship between the two. But between 1926 and 1934 while population continued to grow at a decreased rate, fragmentation decreased, suggesting a negative bivariate relationship between population increase and fragmentation. ${ }^{119}$

\footnotetext{
${ }^{118}$ Following the Balkan Wars of 1912 and 1913, there were both territorial gains and losses; according to Ivanov and Tooze, 6.81 percent was the final net loss of cultivated land.

${ }_{119}$ In 1926 , the average number of parcels per farm was 15 , whereas in 1934 it was 13 . After 1926 population continued to grow but at a decreased rate.
} 
In fact, it can be argued that population growth is consistent with less land per person (land is limited) and therefore less fragmentation — eventually everyone would have one plot that is of minimum size for agriculture; or in other words, population could lead to consolidation of ownership into smaller holdings. For example, a father with three sons and three parcels is likely to give one to each, instead of increasingly minute pieces of the three to each of them - under pressure from population growth, in other words, parcel numbers should logically converge towards farm numbers. However, given the strong tradition of dividing each plot of land among all heirs (which, as explained in the earlier example, would not change the level of fragmentation) it would be impossible to conclude that population growth had negative effect on fragmentation. Therefore, the lack of empirical evidence, or at least some further investigation on the relationship between population growth and fragmentation in Bulgaria, makes it difficult to make a decisive conclusion about the nature of the relationship.

\section{4.1.3 Land Laws and Reforms}

The intervention of government, administrative or communal authorities in the land tenure system of a country may be an important supply-side factor for the emergence or increase in the degree of land fragmentation. For example, the preservation of some open field system aspects ${ }^{120}$ in England and other European countries as well as the policy of

\footnotetext{
${ }^{120}$ The open field system refers to the agricultural system of Europe which was prevalent during the Middle Ages and survived in some places until the $20^{\text {th }}$ century. According to Dahlman $(1980,16-17)$, there is a lack of agreement of what exactly is to be understood by the phrase "open field system" primarily because it was a continuously changing system and involved a multitude of local variations. Dahlman (p. 21-22) describes the following three basic features of the physical structure of the representative open field village: (1) the land of the village would be divided into two different categories: arable and non-arable land - part of the arable land would lay fallow and the rest would be sown with a variety of crops; (2) the arable land would be divided into two or more large fields; and (3) each of the arable fields would be divided into strips which would appear as regular, though not uniform, elongated and narrow subdivisions of land. In his
} 
egalitarian distribution of land in various countries are cited as causes of fragmentation (Bentley 1987; Blarel et al. 1992).

Major government intervention in the land tenure system of Bulgaria took place after the liberation from Ottoman rule and the resulting breakdown of the Ottoman land tenure system in the last quarter of $19^{\text {th }}$ Century. ${ }^{121}$ The first Bulgarian Land Law of 1880 provided for the distribution of previously uncultivated land to peasants in small parcels (Strezov 1913, 45; V'lchanov 1954, 66). ${ }^{122}$ The amount of land a household would be entitled to hold would range between 40 to 60 decares depending on its subsistence needs (V'lchev 1999, 36). ${ }^{123}$ Next, the Law of 1885 required the disintegration of remaining large estates, which, accordingly, were either confiscated or bought out by the state from their owners (gospodars) to be parcellized and distributed to peasants (Strezov 1913, 46; V"'lchanov 1954, 66-67; V'lchev 1999, 35-37). ${ }^{124}$ According to both laws, the maximum amount of land a household could hold was 100 decares. V'lchev explains that the rationale behind the laws was the principle "the land belongs to those who cultivate it"; therefore, the condition to be or become a landowner was to directly cultivate the land.

discussion of fragmentation, Bentley refers to the preservation of these aspects of the open field village. He adds that villagers in England could also own plots which were not part of the open field but were still divided into a large number of strips, or plots.

${ }^{121}$ Refer to Section V.3 of Essay I of the dissertation. This and the next two paragraphs repeat part of that section and it is repeated here to make Essay II self-contained.

${ }_{122}$ The law, according to V"lchanov, provided only use rights: peasants who settled on this "new" land were not allowed to sell or transfer those rights. Ownership of land and transfer of rights would be granted only after 10 years of use. The law was amended in 1902 to increase the period of use before eligibility for ownership from 10 to 20 years.

${ }^{123}$ Toshev $(1937,16)$ argues that 35 decares would be perfect for a household composed of 5 members to meet its needs.

${ }_{124}$ The Law of 1885 is actually an amendment to the principal Law of 1880 , which was also amended in 1883,1896 and 1908 . According to V'lchev the amendment of 1885 is the most comprehensive version of all. 
Essentially, the Law of 1885 reflected the stand of the state against large ownership of land.

As V"lchanov points out, the process of dividing large estates was complicated, difficult to implement, and took many years to take effect. In fact, Table 1 shows that between 1897 and 1908, the enforcement of the law was rather ineffective since there was actually 20 percent increase in the number of farms larger than 100 decares. It is true that those were the years when there was a general expansion of land under cultivation which, as shown in Table 1, led to increase in the number of farms in all size ranges. In spite of this, if the law was in effect, there should have been decrease in the number of farms larger than 100 decares.

In 1921, the newly formed Agrarian government passed the Law of Labour Land Property. As Bell $(1977,162)$ notes, 'just as 'private property' and 'social or communal property' are ideas fundamental to capitalism and to socialism, so the idea of 'labour property' [trudova sobstvenost] became a cornerstone of Agrarian policy." Bell (p. 163) further explains that labour property referred to property directly utilized by its owner to provide for himself and his family. Therefore, Article 1 of the law stated that "the land must belong to those who cultivate it" (V"lchanov 1954, 89). Accordingly, the law decreed that all privately owned land in excess of 300 decares and not farmed directly by its owner be transferred to the state (p. 90). In addition, the landholdings of absentee owners were to be confiscated and distributed to those who own less than 10 decares of land (Bell 1977, 164; Pantev 1996, 15). So the Land Law of 1921 allowed peasant 
farmers and all other private parties to own the maximum of 300 decares of arable land and obliged everyone who owned land to farm it directly. ${ }^{125}$ Therefore, remaining large estates and zadruga ${ }^{126}$ common lands would be subject to subdivision with resulting excess land being subject to expropriation to be redistributed to peasants who did not own land (Crampton 1997, 152; McIntyre 1988, 25; Strezov 1913, Toshev 1937, V"lchanov 1954, 90-91).

Despite the slow pace of expropriation and redistribution, by the mid-1920s, there remained only a few individuals who continued to own large estates and the majority of land holdings could be classified as small. ${ }^{127}$ From Tables 1,2 and 3 it can be seen that the number of farms larger than 500 decares dropped from 3159 in 1908 to 820 in 1926 and 561 in 1934, a decrease of 74 percent between 1908 and 1926 and of 32 percent between 1926 and 1934. Likewise, between 1908 and 1926 there was a decrease of 44 percent in the number of farms in the range 300 to 500 decares; between 1926 and 1934 their number dropped further by 36.5 percent.

The new land laws clearly contributed to the post-liberation division of land - they required the distribution of relatively small parcels of 'new' land; and they required that

\footnotetext{
${ }^{125}$ As Bell $(1977,165)$ explains, "Land owned by monasteries, but not farmed by monks, was made subject to confiscation. Land held by the National and Agricultural Banks and all state-owned arable land not under cultivation were added to the state land fund." Moreover, land over 40 decares held by absentee owners were also subject to confiscation (p. 164).

${ }^{126}$ Zadruga is a form of extended household organization, historically common among the Balkan nations. It was formed of two or more biologically related families who commonly owned and managed their properties, labour and means of subsistence (Todorova 2002, 123).

${ }^{127}$ Bell argues that the enforcement of the laws and reforms was more successful compared to that of the previous laws. Nonetheless, the state did not completely achieve its goal: while it expected to acquire approximately 230,000 hectares, by 1923 , when this government was overthrown, this amount was just less than 82,000 (p. 166).
} 
large estates be destroyed and their land sold or distributed to peasants in smaller parcels. However, we do not have evidence to conclude that these laws contributed to increase in the level of fragmentation, as opposed to an increase in the number of small, but consolidated, farms. It can be argued that the laws might have had an indirect impact on the level of fragmentation since the existence of many small farms plus the opportunity to buy land might have led to fragmentation or at least made fragmentation more likely. In fact, the data shows that the average number of parcels per holding increased by 35 percent (from 11 in 1908 to 15 in 1926), reaching the largest level of fragmentation.

However, parallel to its egalitarian policy of dividing land into smaller parcels, the government had the goal to prevent fragmentation by promoting consolidation for which vigorous measures were immediately established (Bell 1977, 166; Pantev 1996, 15; V'lchev 1999, 108-113). Bell notes that in return for the acquisition of new land, landholders were required to give up their separated strips. Moreover, consolidation was further promoted by providing the opportunity to exchange land in overpopulated areas for a larger, consolidated farm in an unsettled region. V'lchev, on the other hand, points out that facilitating land consolidation has been an important and integral part of the land laws enacted since 1933. Nevertheless, Toshev $(1937,219-220)$ indicates that by 1936 only one village had consolidated its land voluntarily and the land of 40 villages was consolidated as a result of the implementation of government projects. By the end of 1936, only 3.2 percent of the total arable land had been consolidated (Toshev 1937, 220); and by the end of 1944, the percentage of consolidated land increased to just 4 percent of the total arable land (V'lchev 1999, 113). 
To summarize, going back to Table 3 , it can be seen that the highest increase in the average number of parcels for farms less than 50 decares occurred in the period 19081926 when the consolidation initiatives were already in effect. This implies that fragmentation increased despite the efforts and opportunities provided by the government to consolidate land that had been fragmented for whatever reasons. On the other hand, it can be inferred that the new laws created a better environment for fragmentation by the creation of many small farms which might be sold and thus become part of a multi-parcel farm. Therefore, it is likely that the laws had some contribution to the increase in the level of fragmentation in the country.

\section{4.1.4 Change from Collective to Individual Ownership}

The Agrarian government of Bulgaria was overthrown in 1923; however, the land laws remained essentially unchanged until 1945 when the communist government started to collectivize land thereby transferring individual ownership into collective or state ownership. Until 1989 the majority of land was collectively owned and most of the rest was under direct state ownership, so fragmentation of land did not seem to be an issue of concern. ${ }^{128}$ The transition from a centrally planned to a market economy in Bulgaria and other former socialist countries created the need to transform collective ownership of agricultural land into individual ownership. It is often argued that such a transformation has led to division of land, as well as fragmentation (Lerman 2005; Rembold 2003; Sabates-Wheeler 2002; 2005; Thomas 2006; van Dijk 2003; van Dijk and Kopeva 2006).

\footnotetext{
${ }^{128}$ It is possible that the large holdings of land owned by collectives or the state were still fragmented. However, since land was collectively managed and operated, it is likely that the problems faced by individual owners of fragmented holdings would not exist for the collectives and the state. At least, the literature on communist agriculture does not seem to be concerned with such problems.
} 
A defining characteristic of the radical land reform of 1991 was restitution of collective and state farmland, which effectively restored the land ownership rights of most pre1944 owners of agricultural land. Because restitution was a major step in the land reforms following the fall of communism, it is widely held to be the most important factor responsible for the current land fragmentation in Bulgaria (Dirimanova 2004; Howe 1998; Kopeva 2000; Kopeva et al. 2002; Kopeva and Noev 2001; Rembold 2003; Sabates-Wheeler 2005). Logically, restitution of land to pre-1944 owners would create the pre-1944 level of fragmentation. Furthermore, since many of the pre-1944 owners are already deceased, it is believed that the inevitable subdivision of restituted land among present heirs of the original title-owners, contributed further to the increase in fragmentation levels already present in the first half of the $20^{\text {th }}$ Century.

However, in the above analysis, it was shown that no matter its reasons, subdivision of land, in itself, does not necessarily lead to fragmentation. At present, the exact level of fragmentation in the country is unknown. As discussed in Section II. 3, most often the estimates range from 2 to 7 parcels per farm on average which, in fact, implies a decline of between 36 and 80 percent since 1934 when the average number of parcels per holding was 11 (cf. Table 2) - a massive change by any measure. Nonetheless, insofar as the concern is about the impact of the recent land reforms on the level of fragmentation, it seems clear that the policy of restitution created some level of fragmentation relative to the communist period. However, given the efforts of the government to promote for the consolidation of land (MAFS Annual Agricultural Reports of 2004 and 2005), it is not plausible to conclude that government-initiated reforms drive fragmentation. On the 
contrary, if fragmentation is at an alarming level due to the restitution, it is so despite the efforts of the government to promote consolidation.

In conclusion, the above analysis of the four major possible supply-side explanations shows that there is not enough evidence to indicate that fragmentation in Bulgaria was driven by supply-side factors. While the possible influence of one or more of these factors cannot be ignored, it would be naïve to accept without further questioning that this is the whole story behind the causes of fragmentation in Bulgaria. An important question, which is considered the major problem with supply-side explanations, remains unanswered: the supply-side explanations fail to answer the question of why peasants and farmers are unable to recognize the widely-reported productive inefficiency resulting from land fragmentation and thereby consolidate their holdings voluntarily (Heston and Kumar 1983). Furthermore, a question which clearly arises in the case of Bulgaria particularly for the pre-communist period is why fragmentation persisted given the opportunities and economic motivations for consolidation provided by governments (Blarel et al. 1992). The most plausible answer to these questions is that there might be reasons for which farmers are willing to keep fragmented farms. Accordingly, the next section will discuss the possible demand-side explanations for fragmentation.

\section{4.2 Demand-side Explanations}

Demand-side explanations are based on the simple idea that the positive effects of land fragmentation might well outweigh its negative effects and therefore yield net benefits for farmers. Evidence for the impact of demand-side factors on fragmentation were first 
discussed by McCloskey (1975a, 1975b) and Fenoaltea (1976) who argued that, by having scattered plots, individuals systematically diversify their land portfolio in order to stabilize (decrease the variance in) their farm output. Possible demand-side explanations for fragmentation include: (1) the risk aversion of farmers; (2) the goal of farmers to optimize self-employment; (3) low or no costs to fragmentation; (4) land markets; and (5) peasant conservatism. Each of these factors is described and discussed below.

\section{4.2.1 Risk Aversion}

Discussed by McCloskey (1975a, 1975b) in association with European fragmentation and particularly in the context of English open fields, risk-aversion of farmers is the most important factor among the demand-side explanations. ${ }^{129}$ McCloskey (1975a, 114) suggested that fragmentation may be desired as a mechanism to deal with variations in uderdrainage ${ }^{130}$, slope, soil structure and chemistry, crops, exposure to frost, sun, rain, and wind. Basically, the argument is that risk-averse farmers may be willing to split their farms into several pieces in order to have land in different zones with different soil, elevations, altitude or other characteristics of the local environment. Such a diversification of land would aim at spreading the risk from natural hazards (such as frost, hail, flood, or fire) in order to reduce the variability in total output (Blarel et al. 1992; Heston and Kumar 1983) as well as the variability in total income (McCloskey 1975a, 115) due to possible yearly fluctuations in the prices of different crops. ${ }^{131}$ In other

\footnotetext{
${ }^{129}$ To a lesser extent, McCloskey (1975a) also discusses examples from other parts of the world.

${ }^{130}$ In agriculture drainage of- or removal of excess water and alkali from- agricultural land by an underground system of drains.

${ }^{131}$ McCloskey (p. 115) explains that "a year of high prices for wheat could be a year of low prices for oats and barley, adding a price risk to the yield risk, and consequently a peasant would scatter his holdings among the three fields of the village. Under such circumstances, in short, it behooved the peasant to hold
} 
words, farmers, by keeping their plots scattered, may be trying to trade off possible higher returns from consolidated lands for lower variance in output and income over the years. And so they may prefer an agricultural system geared primarily towards stability rather than productivity (King and Burton 1982).

While sources discussing the practice of scattering plots because of such risk-averse behaviour by Bulgarian farmers could not be located, the presence of great variety of soils and topographic characteristics on Bulgaria's territory raises the likelihood of such a demand-side explanation for fragmentation. For example, Georgiev and Penov (2006) point to the specifics of Bulgaria's topography, soil characteristics, and the configuration and structure of crops in different regions as the primary factor for the persistence of fragmentation. ${ }^{132}$

\section{4.2.2 Optimizing Self-employment}

This demand-side factor is first emphasized by Fenoaltea (1976) who argues that farmers may choose to own scattered plots as a mechanism to maximize productivity by optimizing self-employment. ${ }^{133}$ Holding large plots would require hiring of outside labour and farming the field at a given time period. To avoid the high transaction costs involved in the employment of outside labour, such as identifying and supervising workers, farmers may prefer fragmentation since scattered plots could be worked at different time periods thereby allowing the completion of work with minimum or no

many types of land, reducing the variability of his income from year to year, albeit (in view of the inefficiency of tiny scattered plots) at the cost of a smaller average income."

${ }_{132}$ While drawing attention to these factors, Georgiev and Penov do not provide any further discussion on the issue.

${ }^{133}$ Fenoaltea discusses the issue in the context of English open fields. 
outside labour. Based on empirical evidence, Tan, Qu, and Heerink (2005) for example, argue that Chinese farmers prefer to hold scattered plots in order to spread household labour (in addition to spreading risks).

While there is no precise documentation of such reasoning by farmers in Bulgaria, it remains a possibility to consider. Dolinsky (1932), for example, briefly notes that the Bulgarian landowner works the farms himself, uses the labour of his family for all purposes and "in the majority of cases avoids hiring outside labour." Stoianovich (1976) supports this argument by suggesting that the domestic family was organized to perform a great variety of ritualized interrelated functions such as stock-raising and farming through its precise definition of rights, duties, and taboos.

\section{4.2.3 Low Costs to Fragmentation}

Heston and Kumar (1983) draw attention to the possibility of existing low costs to fragmentation given the requirements for transplantation and cultivation. The most important cost associated with fragmentation is the cost of travel time between plots and between the homestead and each plot. If all plots of a farm are located at different places in the immediate vicinity of the village, however, the distance and therefore the travel costs would not be large. Moreover, if plots are farmed and cultivated at different time periods following rotational husbandry ${ }^{134}$ - a phenomenon discussed by Dahlman

\footnotetext{
${ }^{134}$ Rotational husbandry is a universal agricultural practice which requires that part of the land lie in fallow each year. Dahlman explains the reason for the practice being that "with more intensive cropping the soil would become exhausted, and a period of rest would be necessary to avoid declining yields." Parallel to rotational husbandry is crop rotation which is the practice of growing a series of different types of crops on the same plot in sequential seasons. The practice aims at preventing the excessive depletion of soil nutrients and the build up of pathogens and pests which is observed when a single type of crop is continuously
} 
$(1980,108-111,122)$ in the context of English open fields - then the waste of travel time between plots would not be a matter of consideration. ${ }^{135}$ In such cases, a farmer would not be concerned with costs created by fragmentation since they would be minimal or no higher than if he had to work on a consolidated or single plot of land. And furthermore, from an economic point of view, it is not time per se that matters, but the value of that time measured as the opportunity cost of production foregone (King and Burton 1982). Therefore, when costs to fragmentation are low or effectively non-existent but there are some benefits, fragmentation will likely occur.

Although fragmentation in Bulgaria has not been previously analyzed in terms of the above demand-side considerations, it is possible that they may hold true. For example, Bishop et al. $(1995,92)$ briefly notes that fragmentation in Bulgaria is rooted in the feudal land structure, where following crop rotation, farmers would sow particular seeds on particular parcels located in different places around the village. Such a field structure, therefore, may be the reason for farmers' preference to own and keep scattered parcels. Toshev $(1937,28-29)$ argues that the costs of agricultural production in fragmented holdings are slightly higher than those in consolidated ones. But the costs perceived by the farmer himself do not necessarily match with the calculations of the agricultural policymaker. Given the primitive agricultural practices in Bulgaria, the prevalence of subsistence farming, the application of crop rotation, and given the low or even non-

grown. The choice of crop rotation would depend on the available agricultural techniques, soil condition, relative output prices, and demand for the final products (p. 108-109).

${ }^{135}$ When a plot lies in fallow, the farmer does not need to work on it so he does not need to make frequent trips to the plot. Also, if he grows different crops on different plots following crop rotation, each parcel would be worked at different times so he will not need to travel to all plots in a given day. 
existent opportunity costs of travel time, the costs of fragmentation may not have been perceived as high by Bulgarian farmers.

\section{4.2.4 Land Markets}

Fragmentation can be a natural consequence of the operation of land markets when a farmer buys a plot or plots of land located at a place far from that of the plot or plots they already own (non-contiguous plots). The reasons for which a farmer may buy noncontiguous plots vary but at large they are closely related to the above discussed demandside factors.

Bulgarian peasants started to buy land when the radical Ottoman Land Reform of 1858 granted individuals the right to own land (cf. Section IV.2 of Essay I). Officially, the land still belonged to the Sultan and legal rights to land property were rather unclear. Nonetheless, the reforms conferred virtual ownership to those who had worked the land for three or more years which led Bulgarian peasants to become individual proprietors of the land they farmed (Bishop et al. 1995, 91; Howe 1998, 209; Stoianovich 1976). The comprehensive study of Draganova (2005) of the Danubian Province ${ }^{136}$ concludes that purchases of land by Bulgarian peasants were so frequent that by the $1870 \mathrm{~s}$, the Bulgarian population owned more land than the Ottoman Turks in the region (p. 227). According to the calculations of Draganova, which are based on data from the Ottoman land registries for Bulgaria, in the period 1872-1877, the average number of parcels per farm ranged from 2 for farms less than 20 decares to 43 for farms greater than 2000

\footnotetext{
${ }^{136}$ The Danubian Province [Dunavski Vilaet] was created in 1864 as part of the Tanzimat reforms of the Ottoman state. The area of the province was quite large and included the region from along the Danube River to the Balkan Mountains (Draganova 2005, 25-26).
} 
decares (p. 84-86, 93). Furthermore, the overall average number of parcels per farm was 11.4. Often, the parcels of farms were scattered very far from each other and in most districts of the Danubian Province the average number of parcels per farm was higher for Bulgarian households as opposed to Ottoman Turks' households (p. 85, 93-97). Draganova reports that the higher parcellization and fragmentation of land in Bulgarian landholdings is associated with the transfer of land from Ottoman Turks to Bulgarian peasants resulting from the documented massive purchase of land by Bulgarians in the early second half of $19^{\text {th }}$ century. This implies that if a farmer wanted a bigger farm it often had to be a fragmented farm. ${ }^{137}$

The results of this study are interesting since they point to the overwhelming presence of fragmented farms before liberation from Ottoman rule and to the voluntary choice to acquire scattered parcels. However, it is difficult to answer the question of why exactly peasants were buying scattered parcels. Following Bentley (1987) it can be speculated that, with the purchase of small plots of land, the peasant may intend to secure his family's future; to provide subsistence crops; to generate income from renting the land; to use the land as a form of savings and investment; and to use the land as a building site, or a patrimony for his heirs. ${ }^{138}$ Sanders (1976), for example, argues that the Balkan peasantry is rooted in the soil, the mystical and close attachment to which is a consequence of their viewing the land as the most important means of security. Wakaley (1958) goes further to assert that his own land is the sole security of the peasant because

\footnotetext{
${ }^{137}$ Recall from the figures in Table 1 and Table 2 that the larger the farms the higher were the levels of fragmentation.

${ }^{138}$ This could not be accomplished with a single plot because the peasant would need one or more plots of land for his family's subsistence, keep one as a future investment or for renting purposes, to use another plot as a building site and so on
} 
it means freedom from want and tyranny. Furthermore, Georgiev and Penov (2006) indicate that land in Bulgaria is viewed not only as a means of production but also as a means of investment. Indeed, the next sections will show that, at present, a large number of landholders do not cultivate the land they own but they do not sell it either. And other reasons may include the above discussed demand side-factors.

As discussed in Essay I of this dissertation, the transfer of land ownership from Ottoman Turks to Bulgarian peasants accelerated after liberation. This transfer was partly a result of further sales and purchases of land. But it was also a result of the seizure by Bulgarian peasants of state land as well as the land of Ottoman Turks who fled the country after the disintegration of the Empire. The Provisional Russian Administration and the subsequent Bulgarian governments supported and facilitated in various ways a thoroughly egalitarian but illegal access to land (Bell 1977, 12; Berov 1979, 48; Crampton 1983, 184; McIntyre 1988, V"lchanov 1954, 63, 69). Bell notes that the Russian occupation authorities and later the Bulgarian government confiscated Turkish estates and sold them in small parcels. Berov suggests that vast amounts of land were compulsorily transferred by the courts to peasant ownership. V'lchanov notes that by 1888 all seized land was legalized by providing legitimate titles of ownership to those who claimed the land. Berov (1984, 257) provides evidence that the increase in private ownership of land in the period 18741897 was due primarily to the massive acquisitions of parcels of land by, perhaps, relatively wealthier (medium and large) landholders. By the end of 1897 more than 41 percent of the arable land was privately owned which according to Yovchevska (2002) 
was a result of the steady increase in purchase of land by individuals or other private parties.

Such a massive transfer of land properties to peasants raises the possibility that the fragmented farm structures demonstrated by Tables 1 and 2 were to a great extent due to peasants' own choice of acquiring scattered plots of land, either by means of purchase or by means of squatting and seizure of land.

\section{4.2.5 Conservatism of Peasants}

The reluctance of peasants to accept consolidation of land as a better or more efficient way of farm organization, as it is promoted by governments and various organizations might also be explained by their conservatism. According to Sanders (1976), the Balkan peasants' conservatism can be described or explained in several ways. The first is that peasant farmers' folk wisdom about the parcels of land he owns is superior to the knowledge of the agricultural advisor who would urge him to 'modernize.' The second view is that looking from the perspectives with which the peasant views the world, he is actually highly rational - he only seems irrational to those who do not understand that perspective. Sanders supports a third view, which "admits to the inefficiency inherent in peasant farming and its relatively low standard of living but attributes much peasant conservatism to the lack of margin with which the peasant has to experiment. If he tries one or two new ideas and they do not work out, it is not the agricultural expert's children who go hungry; it is the peasant's children." ${ }^{139}$ Sanders argues that the Balkan peasant will not change when outside authority urges him to do so on the grounds of science or

\footnotetext{
${ }^{139}$ It should be noted that such conservatism may as well be related to peasant's risk aversion.
} 
politics but will change when desirable effects are demonstrated and the motivation and means for change are provided.

If there is truth to these views, then the conservatism of peasant farmers can be viewed as a demand-side explanation for fragmentation for the lack of movement away from preexisting fragmentation. And if Sanders is correct, then in the context of promoting consolidation policies, his argument raises the implication that the peasant has not been convinced about the superiority of consolidation. On the other hand, Wakaley (1958) asserts that peasants resist consolidation of agricultural holdings since they involve exchange of small plots of land which belonged to the family and family property is "of a strong sense" for the peasant. ${ }^{140}$ Furthermore, the peasant is characterized as someone who considers the state as an impersonal external force to be feared and who expects to lose through any change proposed by government. Therefore, in the interest of selfpreservation, the peasant must resist change and must preserve what he has.

To conclude, while it is difficult to verify the extent to which the above discussed demand-side explanations for fragmentation hold true in the case of Bulgaria, the analysis points to their possibly strong effect, particularly to that of the functioning of land markets which seem to have facilitated the voluntary acquisition of scattered parcels. At the very least, the above discussion of both supply-side and demand-side factors points to the necessity for their further investigation. The causes of fragmentation in Bulgaria deserve a more comprehensive research in order to improve our understanding of

\footnotetext{
${ }^{140}$ By "strong sense" Wakaley refers to the sentimental value which the peasant attaches to his piece of land: if land belonged to the family for years, then the peasant would tend to keep it.
} 
fragmentation and in order to develop the relevant criteria for any required policy selection and design.

\section{5 Review of the Evidence on the Impacts of Fragmentation}

As mentioned in the introduction to this section, empirical studies conducted in various countries provide mixed evidence of the impact of land fragmentation on various economic outcomes. Therefore, it seems to be impossible to generalize the results, thereby making it necessary to consider each society or community as a unique case before making the decision that fragmentation is necessarily a problem requiring a public policy solution. This section will briefly review some of the evidence on the impacts of fragmentation on productivity and other economic indicators.

It is important to note that the number of studies which attempt to formally test the impacts of fragmentation is surprisingly limited. Moreover, many suffer from conceptual flaws, data, and methodological limitations. The discussion of these issues, however, is beyond the scope of the thesis. Therefore, the review is limited to providing a summary of some of the studies in Table II.1 below. As the table shows, the studies that use production function methods report negative impacts of fragmentation. Two of the studies which use multiple regression analysis report no negative impacts. The study of Blarel et al. (1992) is discussed in more detail below because it is the most relevant to this research; further discussion on the methodology of Blarel et al. and its application to this study is presented in the next section of the essay. 
Table II.1 Review of Studies on the Impacts of Fragmentation on Various Economic Indicators

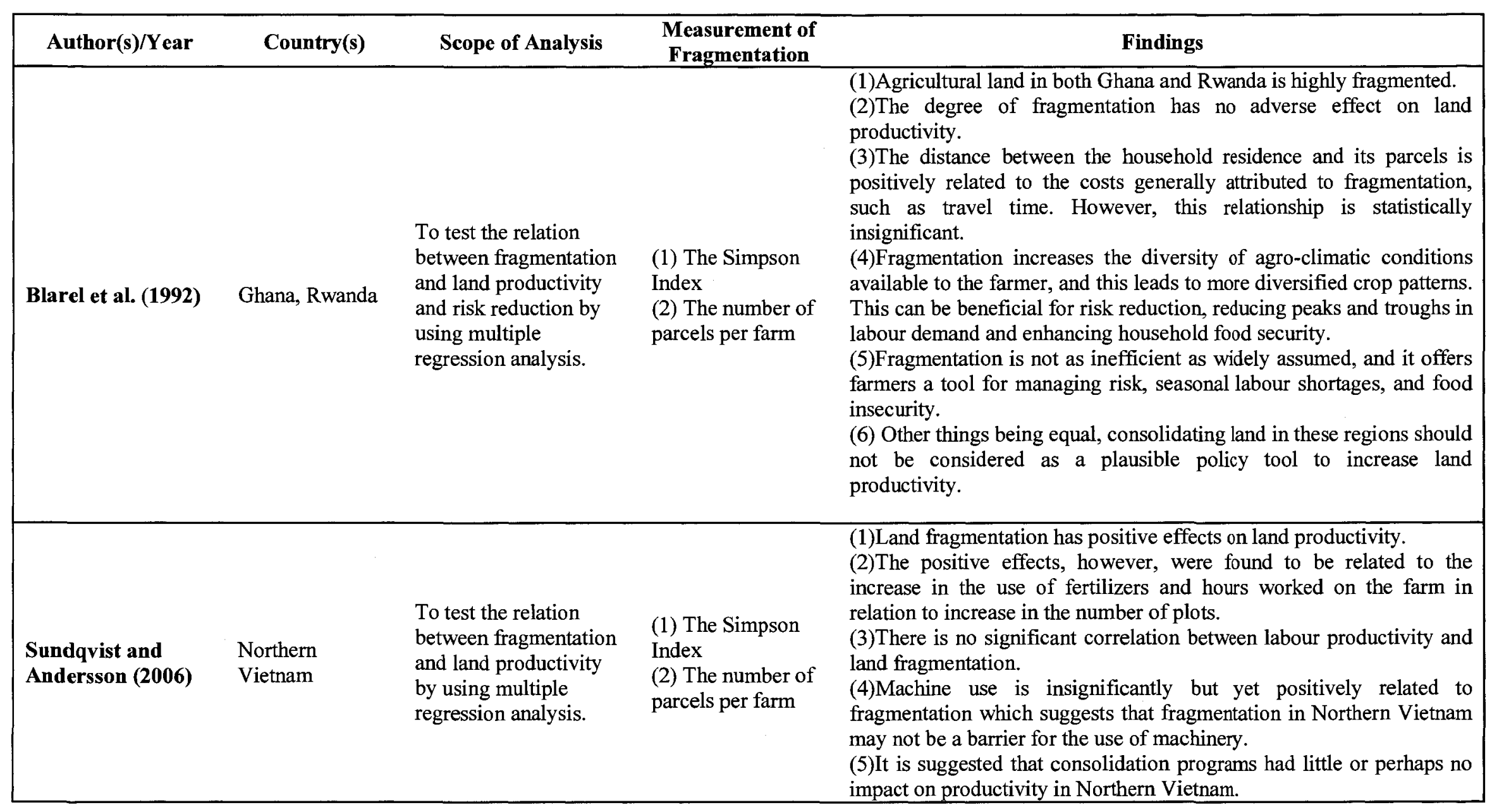


Table II.1 Continued

\begin{tabular}{|c|c|c|c|c|}
\hline Author(s)/Year & Country(s) & Scope of Analysis & $\begin{array}{c}\text { Measurement of } \\
\text { Fragmentation }\end{array}$ & Findings \\
\hline
\end{tabular}


Table II.1 Continued

\begin{tabular}{|c|c|c|c|c|}
\hline Author(s)/Year & Country(s) & Scope of Analysis & $\begin{array}{l}\text { Measurement of } \\
\text { Fragmentation }\end{array}$ & Findings \\
\hline $\begin{array}{l}\text { Wan and Cheng } \\
\text { (2001) }\end{array}$ & $\begin{array}{l}\text { Four provinces } \\
\text { in China }\end{array}$ & $\begin{array}{l}\text { To examine the effects } \\
\text { of land fragmentation } \\
\text { on five major crop } \\
\text { outputs by using a } \\
\text { production function } \\
\text { model. }\end{array}$ & $\begin{array}{l}\text { The number of } \\
\text { plots per farm }\end{array}$ & $\begin{array}{l}\text { (1)The highest degree of fragmentation is observed on farms producing } \\
\text { rice, the lowest on farms producing maize. } \\
\text { (2)Land fragmentation has adverse effects on outputs in every crop } \\
\text { production. } \\
\text { (3)China's grain output could rise by } 71.4 \text { million metric tons simply } \\
\text { by eliminating land fragmentation. The gains in output are most } \\
\text { apparent in tuber and wheat production } \\
\text { (4)Eliminating fragmentation does not mean each family being } \\
\text { allocated one piece of land. Rather, it only requires that individual } \\
\text { crops be planted on the same block at the family farm level. } \\
\text { (5) The implementation of consolidation is strongly recommended. }\end{array}$ \\
\hline Lerman (2005) & $\begin{array}{l}\text { Four districts in } \\
\text { Georgia }\end{array}$ & $\begin{array}{l}\text { To explore the impact } \\
\text { of farm fragmentation } \\
\text { on productivity. }\end{array}$ & $\begin{array}{l}\text { (1)The Simpson } \\
\text { Index } \\
\text { (2)The number of } \\
\text { parcels per farm } \\
\text { (3)The average } \\
\text { distance to the } \\
\text { parcels in each } \\
\text { farm }\end{array}$ & $\begin{array}{l}\text { (1)Farm productivity decreases with the increase in the number of } \\
\text { parcels but the relationship is not statistically significant. } \\
\text { (2)Fragmentation has a significant negative effect on productivity. } \\
\text { (3)Productivity depends not only on fragmentation but on additional } \\
\text { variables, such as farm size The study does not indicate if } \\
\text { fragmentation remains when farm size is being controlled for. } \\
\text { (4)Total factor productivity decreases as fragmentation and crop } \\
\text { specialization increases. } \\
\text { (5) Technical efficiency decreases as fragmentation increases. }\end{array}$ \\
\hline
\end{tabular}


Blarel et al. (1992) develop a household-level econometric model to formally test the relation between fragmentation and land productivity. Their model was applied using household-survey data in three regions in Ghana and Rwanda. Fragmentation was measured by using the number of parcels per farm, on one hand, and the Simpson Index, on the other. In the case of Ghana, neither the Simpson index nor the number of parcels had a significant effect on parcel yields leading to the rejection of the hypothesis that fragmentation is inefficient. In some regions, the distance to parcel was significantly related to yield. However, this relationship was positive for some regions (Anloga and Wassa) and negative for others (Ejura). ${ }^{141}$ In all cases parcel size was found to be negatively related to yield per hectare.

Similarly, neither the Simpson index nor the number of parcels had a significant effect on yields in Rwanda which suggested no negative impacts of fragmentation. In none of the regions was farm size significantly related to yields but in all cases parcel size was negatively associated with yield. The distance to parcels was positively related to yields of coffee but had negative yet insignificant effect on yields of some sorghum intercrops. ${ }^{142}$ Results of the study indicated that although agricultural land in both Ghana and Rwanda can be considered highly fragmented, this degree of fragmentation does not seem to adversely affect land productivity.

\footnotetext{
${ }^{141}$ The regions differ by crop, soil fertility, and other characteristics. The explanation of Blarel et al. is that in Anloga, "the more fertile of two primary growing areas, and that which is more prone to flooding, is located farther from the villages. In the case of Wasa, the farther parcels are those located on more recently developed lands which are fresh in nutrient composition and not yet largely exploited. In Ejura distances to parcels are much longer compared to those in the other two regions.

${ }_{142}$ This could suggest crop specific effects.
} 
Overall results of the study support the demand-side explanations of farmers' riskaversion and their resulting desire to diversify land and crops, as well as the desire to minimize labour costs. As reported in Blarel et al. (1992) "... fragmentation increases the diversity of agro-climatic conditions available to the farmer, and this leads to more diversified crop patterns. This can be beneficial for risk reduction, reducing peaks and troughs in labour demand and enhancing household food security.... Fragmentation is not as inefficient as widely assumed, and it offers farmers a tool for managing risk, seasonal labour shortages, and food insecurity when other alternatives might be more costly." Therefore, the study concludes that, other things being equal, consolidating land in these regions should not be considered as a policy tool to increase land productivity. ${ }^{143}$ Blarel et al. suggest that policies should target and focus on improving the functioning of the rural credit, labour, and food markets since they seem to be the major causes for the agricultural inefficiencies observed in both countries.

As mentioned before, land fragmentation in Bulgaria recently re-emerged as a direct result of the land reforms initiated after the fall of the communist regime and the consequent breakdown of the collective and state ownership structure. It is surprising, however, that it was only recognized as a problem when the restitution process was nearly complete. The few available studies on agricultural land fragmentation in Bulgaria emphasize the negative impacts discussed in the general literature, emphasize the superiority and merits of consolidation, and strongly recommend land consolidation

\footnotetext{
${ }^{143}$ The results may be interpreted as a situation where farmers maximize food security rather than land productivity. This implies that productivity might increase as a result of the consolidation of land holdings but that the means to get it may be rejected by the farmers themselves.
} 
policies. Surprisingly, however, none of them actually studies fragmentation. For example, the most widely cited studies include Kopeva (2000), Kopeva et al. (2002), and Kopeva and Noev (2001). Insofar as the issue of fragmentation is of concern, these studies go little further than illustrating that land in Bulgaria is divided into small fragmented holdings. No formal testing and therefore no significant empirical evidence are presented to support the argument that fragmented land in Bulgaria has adverse effects on economic outcomes.

The studies of Dirimanova (2005) and Todorova and Lulcheva (2005) attempt to test the impacts of land fragmentation on land market development and productivity, respectively. Dirimanova (2005) employs a qualitative comparative study of two contrasting districts in Bulgaria, one considered to be less fragmented and the other one to be the most fragmented. Fragmentation is inappropriately measured by average plot size so that the region with the lowest level of fragmentation on the national level has an average plot size of 20.3 decares and the region with the higher level of fragmentation has an average plot size of 5.3 decares. Data is collected from interviews with representatives from agricultural offices and village mayors, not from households. The number of villages is not indicated. The study is confusing because it is not clear what is meant by fragmentation. While it is defined as the situation where a household operates more than one plot of land, the criterion for its measurement is regional average plot size. Furthermore, the study does not clearly establish the methodology by which the relationship between fragmentation and land markets will be tested. The two regions are 
simply compared based on a number of regional characteristics such as restitution and reform processes, soil and crop quality, farm practices, and others.

The study concludes that the operation of land markets in both regions is rather poor (meaning that a few plots of land are being bought or sold) primarily due to unclear property rights, the low value of farm land, landlords' sentimental attachment to family land, and expectations of a rise of the value of land following EU accession. So the role of fragmentation here is unclear. Land fragmentation is argued to be a problem for the farming system but evidence for such conclusion is not presented. An interesting finding is that the number of land transactions is higher in the region with higher level of fragmentation. The study does not comment on this finding which may actually be considered as an indicator of better land market operation in the fragmented region. Since the results of the study are not based on an appropriate methodology necessary to establish the relationship between fragmentation and land markets, it can be inferred that they are insufficient to conclude that fragmentation, measured by average plot size, has adversely affected the development of land markets in the two regions.

Todorova and Lulcheva (2005) use data from observations on the activities of the largest agricultural cooperative in one region in Bulgaria in order to test the economic and social impacts of land fragmentation on the productivity of that cooperative, owned by more than 2000 members. The study period is five years (1996-2000) and the choice of measurement of fragmentation is the Januszewski Index. During the five year period of study, the cooperative farm underwent various structural changes. One of the changes 
was in the number of parcels, which increased from 90 in 1996 to 3400 in 1998; decreased to 2850 in 1999 and to 1630 in 2000 . Furthermore, the size of the cooperative farm fell from 3800 to 1775 hectares and in 2002 it was no longer in operation.

The study shows that during the five years of observation the index of fragmentation decreases from 0.11 to 0.02 indicating a considerable increase in the level of fragmentation which, initially, was already high. It is asserted without evidence that this level of fragmentation constitutes a problem adversely affecting productivity, production levels, profitability, material and labour costs, and other factors. The problem with the study is that its analysis relies on simple descriptive data. While there is a detailed description of how the level of fragmentation had increased over the period from 1996 to 2000 and how yield productivity, costs, and overall profitability have changed in both positive and negative directions over that period, their relationship with fragmentation is not clearly established. In other words, the evidence pointing to the negative impacts of fragmentation is rather weak. As in the case of Dirimanova (2005), the study fails to employ an appropriate model to establish the necessary links and to control for the relevant variables of concern.

The review of the studies with respect to the impact of land fragmentation on economic outcomes leads to the following conclusions: (1) there is a conceptual similarity in defining fragmentation but there are differences in its measurement; (2) measuring fragmentation by the number of parcels per farm alone or by the average parcel size alone may lead to misleading results, given other parameters essential to the study of 
fragmentation; (3) the findings on the impacts of fragmentation differ not only across countries but also when an identical region is of concern (e.g. Northern Vietnam) - this raises concerns about the collection and use of data and about methodologies; (4) there is a need for further research on the causes of fragmentation observed in each of the above studies, some of which report the desire of farmers to keep fragmented farms but which do not attempt to further inquire the rationale behind this desire; (5) there is a need for further research in terms of developing better methodologies and in terms of assessing if, how, to what extent, and under which circumstances fragmentation affects productivity.

\section{6 Conclusion}

Section II of this essay provided a literature review on the nature of land fragmentation, its measurement, its causes, and its relation to land productivity. There are four major implications of this discussion which are of particular importance to the study of fragmentation in Bulgaria. First, there is a need to clearly differentiate the issue of undersized farms from the issue of fragmentation (defined as the situation where a farm is composed of more than one plot of land.) Second, there is a need for consistency in the ways in which fragmentation is measured. The indices developed so far are limited to incorporating three of the six parameters necessary to study fragmentation. Nonetheless, the indices are a better measure than the national average of the number of parcels per farm. Third, there is a need to study, in detail, both the supply-side and demand-side factors that might explain the causes of fragmentation in Bulgaria. The arguments that fragmentation in the beginning of the $20^{\text {th }}$ century emerged and persisted because of population growth and partible inheritance are neither justified nor supported with 
evidence. It is true that the land reform of 1991 led to the re-emergence of fragmented farms but resistance to consolidation initiatives raises questions about farmers' desire to keep fragmented farms. Investigating the demand-side causes of fragmentation is of particular interest because theoretical and empirical evidence suggests that they may have had strong effect both on the emergence and persistence of fragmentation. Fourth, the impacts of fragmentation on land productivity and other economic outcomes in Bulgaria have not been studied yet. The majority of studies focus on the plausibility and methods of implementing consolidation without actually studying fragmentation. The two studies which attempt to test the impacts of fragmentation are conceptually flawed, greatly limited in scope, data, and methodology. The conduct of further comprehensive research in these directions would therefore be of much benefit in improving our understanding of the causes and impacts of fragmentation. 


\section{Methodology}

The econometric model developed by this study to formally test the impact of fragmentation on land productivity in Bulgaria is based on the econometric model formulated by Blarel et al. (1992).

The key equation of the four-equation model specifies that the dependent variable, the total value of harvested crops per decare, is related to a set of household-level variables including (1) the level of farm fragmentation (F); (2) the parcel-level use of direct inputs $\left(\mathrm{L}_{\mathrm{i}}\right)$; and (3) the current stock of land improvements on each parcel $\left(\mathrm{I}_{\mathrm{i}}\right){ }^{144}$ Other independent variables of the model are specified as (1) the set of parcel-specific characteristics $\mathrm{X}_{1 \mathrm{i}}$; (2) the set of household specific characteristics $\mathrm{X}_{2}$; and (3) district specific characteristics $\mathrm{X}_{3}$. The subscript $i$ indicates the parcel number and the absence of a subscript indicates a variable measured at the household level which will be common to each parcel owned by the household.

Following Blarel et al. (1992), the four simultaneous equations of the structural model are as follows:

\footnotetext{
${ }^{144}$ The current stock of land improvements refers to the investments in the improvements to the land made in order to prepare land for its intended use, improve its productivity or meet special needs of the landowner. Examples include clearing land of trees and stones, building water supply systems, ponds, fences, roadways, draining of marshes, site excavations, landscaping, and conservation measures.
} 


$$
\begin{array}{ll}
Y_{i}=f\left(F, L_{i}, I_{i}, X_{1 i}, X_{2}, X_{3}\right) & i=1,2, \mathrm{~K} n \\
L_{i}=f\left(I_{i}, F, X_{1 i}, X_{2}, X_{3}\right) & i=1,2, \mathrm{~K} n \\
I_{i}=f\left(F, X_{1 i}, X_{2}, X_{3}, I_{i, t-1}\right) & i=1,2, \mathrm{~K} n \\
F=f\left(X_{2}, X_{3}\right) &
\end{array}
$$

Equation (1) determines the dollar value of the yield of the $i^{\text {th }}$ parcel; equation (2) determines the level of direct inputs used on the $i^{\text {th }}$ parcel; and equation (3) determines the current stock of land improvements made to the $i^{\text {th }}$ parcel. Finally, equation (4) determines farm fragmentation at the household level.

More specifically, in equation (1), the parcel yield is determined by the use of direct inputs $\left(\mathrm{L}_{\mathrm{i}}\right)$, the current stock of land improvements on the parcel $\left(\mathrm{I}_{\mathrm{i}}\right)$, the level of farm fragmentation for the household $(\mathrm{F})$, parcel-specific variables $\left(\mathrm{X}_{1 \mathrm{i}}\right)$, household-specific variables $\left(\mathrm{X}_{2}\right)$, and district-specific variables $\left(\mathrm{X}_{3}\right)$. In equation (2), the level of direct inputs used on the $i^{\text {th }}$ parcel is determined by the current stock of land improvements, the level of farm fragmentation, as well as the previously-noted parcel, household, and district variables. In equation (3), the current stock of land improvements on each parcel is determined by the level of farm fragmentation, land improvements made in the previous period on the parcel $\left(\mathrm{I}_{t-l}\right)$, as well as the parcel, household, and district variables. Finally, in equation (4), the level of farm fragmentation is determined by the householdspecific and district-specific variables $\left(\mathrm{X}_{2}, \mathrm{X}_{3}\right)$. 
It should be noted that in equations (1) - (3) fragmentation is determined at the parcel level. In equation (4), however, fragmentation is determined at the household level. Such a specification is necessary because it is unknown whether fragmentation is driven by supply-side or demand-side factors. In other words, it is necessary to take into account both the supply-side (partible inheritance, population growth, land laws and reforms, change of ownership type) and demand-side (risk aversion, optimizing self-employment, low cost to fragmentation, land markets, conservatism of farmers) explanations for fragmentation discussed in Section II of this essay. The conclusion was that fragmentation can be either an exogenous phenomenon (driven by supply-side factors) or a feature that is desired by farmers (a choice variable) in their selection of specific parcels of land.

Furthermore, fragmentation appears in equation (1) as an explanatory variable, and therefore directly affects the yield of the $i^{\text {th }}$ parcel. Fragmentation also appears in equations (2) and (3) as an explanatory variable and therefore directly affects the level of direct inputs $\left(\mathrm{L}_{\mathrm{i}}\right)$ and the stock of land improvements $\left(\mathrm{I}_{\mathrm{i}}\right)$. Since $\mathrm{L}_{\mathrm{i}}$ and $\mathrm{I}_{\mathrm{i}}$ are included as the explanatory variables of equation (1), fragmentation has both direct and indirect effects on the yield of the $i^{\text {th }}$ parcel. 
Equation (4) does not include the current values of the other endogenous variables, $\mathrm{Y}_{\mathrm{i}}, \mathrm{L}_{\mathrm{i}}$, or $\mathrm{I}_{\mathrm{i}}$. Therefore, the model can be specified in the following semi-reduced form:

$$
Y_{i}=f\left(F, X_{1 i}, X_{2}, X_{3}\right) \quad i=1,2, \mathrm{~K} n
$$

In equation (5), the fragmentation variable captures both the direct and indirect effects of fragmentation on yields. However, equation (5) may not produce the consistent and unbiased estimates of direct and indirect effects of fragmentation on yield if there are unobserved variables that influence both the level of fragmentation and current yield, such as farmer's skill. ${ }^{145}$ In other words, $\mathrm{F}$ is an endogenous variable and any correlation between the error term in equation (4) and the error term in equation (5) will lead to biased coefficient estimates. To solve this problem, using two-stage least squares, equation (4) is estimated first to obtain the fitted values for F which will be used to replace the actual values of fragmentation in equation (5).

More specifically, it is necessary to estimate the following household-level model to obtain the fitted value for fragmentation:

$$
F_{j}=b_{1} X_{2 j}+b_{2} X_{3 j}+e_{j} \quad j=1,2, \ldots m
$$

\footnotetext{
${ }^{145}$ As discussed in Section II, supply-side explanations do not include farmer's skill as a determinant of fragmentation. However, in the light of demand-side explanations, a farmer who is experienced in operating and managing more than one plot in the face of risk from natural and other hazards, who aims at maximizing self-employment, or who needs two or more plots to better manage crop rotation could influence the level of fragmentation.
} 
In this equation $\mathrm{F}_{\mathrm{j}}$ is the number of parcels in the $j^{\text {th }}$ household; $\mathrm{X}_{2 \mathrm{j}}$ is a vector of household-level explanatory variables; $\mathrm{X}_{3 \mathrm{j}}$ is the vector of district-level variables; $\mathrm{b}_{1}$ and $b_{2}$ are the vectors of the coefficients to be estimated; and $e_{j}$ is an error term. The explanatory variables represented by $\mathrm{X}_{2 \mathrm{j}}$ are the variables dealing with householdspecific characteristics such as family size, gender and formal education of the household head, inherited farm size, number of inherited parcels, credit use, and non-farm income. The fitted $\hat{F}_{j}$ values will be assigned to the parcels associated with the $j^{\text {th }}$ household.

It is important to note here that inherited farm size, number of inherited parcels, and credit use would normally be included in the list of explanatory variables and they might have been used to evaluate the supply side arguments for fragmentation. However, in the case of Bulgaria this seems unnecessary. While the 2003 Multi-topic Household Survey (MHS) data, used for this study and discussed in the next section of the essay, does not provide specific information on inheritance, it is well known that, until the initiation of the restitution process in 1991, no one was able to inherit farm land due to the lack of individual ownership property structures during the communist regime. Therefore, due to restitution, at present, most land owners are already considered heirs and only few of them seem to have actually purchased agricultural land. In other words, it is reasonable to assume that the majority of parcels are inherited. With respect to the use of credits for agricultural purposes, the survey data indicates that households do not use credits. A consultation with D. Dimitrova of the National Statistical Institute of Bulgaria (NSI) and 
Dr. I. Yanakieva of the Institute of Agricultural Economics revealed that this is so simply because they were unable to obtain loans. ${ }^{146}$

Therefore, the explanatory variables included in $\mathrm{X}_{2 \mathrm{j}}$ are as follows: household size, gender, farm size, education, and distance to parcels. ${ }^{147}$ The model is identified by the inclusion of farm size in equation (4), a variable which is strongly related to fragmentation but, as will be explained in the next paragraphs, not directly related to productivity. Farm size is a powerful instrumental variable since it directly affects fragmentation - recall from Section II that Simmons (1964) and Januszewski (1968) suggested evidence that fragmentation increases with farm size. Furthermore, recall that simple tabulation of the historical data for Bulgaria supported this argument - for the period between the last quarter of the $19^{\text {th }}$ century and the mid-1930s the level of fragmentation was positively related to farm size - the higher the farm size, the higher

\footnotetext{
${ }^{146}$ Dimitrova discussed the following reasons for the inability of farmers to obtain credits: (1) in 2003, the year during which the NSI conducted the MHS, loans to be used for agricultural purposes were not provided to households - only in the past 3-4 years have special loan products been developed and presented for use by small and medium farm owners; (2) applying for a loan requires the owner of the farm to develop a business plan which challenges farm owners, the majority of whom do not know how to develop and present such a plan; and (3) obtaining a loan requires initial expenses to meet certain criteria and standards for quality and safety of food produce as well as for safety and protection of the environment. Dr. Yanakieva added that agricultural production is a low-income and risky business demanding a considerable capital investment. Farmers do not have access to such capital since they are unable to meet the various loan security requirements. An important barrier to credit access is the fact that agricultural land is not accepted as collateral by banks. The European Union's Special Accession Programme for Agriculture and Rural Development (SAPARD) provides an opportunity for financing but even this program requires that farmers provide half of the initial capital which is still too high for the majority of them. In addition, landowners still lack access to information regarding opportunities and requirements for financing. They lack not only the ability and skills to develop business project plans but also the ability to properly complete the paperwork and other application procedures which seem to be rather complicated, voluminous, and costly, especially for the small landowner.

${ }^{147}$ Non-farm income is excluded since it is considered an endogenous variable.
} 
was the level of fragmentation. And furthermore, in the MHS data, farm size is strongly related to the number of parcels. ${ }^{148}$

The econometric procedures explained above will produce fitted values of fragmentation that are not correlated with the error term of equation (5). However, it needs to be underlined that the explanatory power of the variables included in the other equation of the model will be determined by the degree of correlation between the fitted values and observed values of fragmentation.

Following Blarel et al., equation (1) will be estimated in double log form for parcel $i$ of household $j$ located in district $k$ as follows:

$$
\log Y_{i j}=\alpha V_{k}+\beta_{1} \log X_{1 i j}+\beta_{2} \log X_{2 i j}+\beta_{3} \hat{F}_{i j}+\mu_{j}+e_{i j}
$$

In this equation $\mu_{\mathrm{j}}$ is a household random effect satisfying $E\left(\mu_{j}\right)=0, E\left(\mu_{j}^{2}\right)=\sigma_{\mu}^{2}$, and is independent across households. As explained by Blarel et al. (p. 245), $\mu_{\mathrm{j}}$ represents unobserved household-level effects. The household random effect $\mu_{\mathrm{j}}$ may be correlated with explanatory variables other than the fitted values of fragmentation ${ }^{149}$.

\footnotetext{
${ }^{148}$ The link between farm size and parcel yiled will be discussed below.

${ }^{149}$ On the other hand, since this study focuses mainly on the coefficient of fragmentation, and because fitted values that are used for $F_{j}$ are not correlated with $\mu_{j}$, the coefficient of fragmentation will not be biased. Interpreting the coefficients other than the coefficient of $F$, however will require caution.
} 
Equation (7) includes the fitted values for fragmentation and all other variables with the exception of farm size. Since farm size is the instrument of the first stage equation it cannot be a determinant of the second stage equation's dependent variable, parcel yield.

An obvious objection to excluding farm size from the productivity equation would be the argument that due to economies of scale, farm size will necessarily affect productivity. However, as will be seen, in the MHS data the majority of farms are smaller than 50 decares and, in fact, more than 50 percent are smaller than 20 decares. For such small farms, there are no opportunities to explore economies of scale. Furthermore, as will be discussed in the next section, the figures for Bulgaria in general indicate that 77 percent of farms use no more than 10 decares of agricultural area. Sources indicate that large business farms and agricultural cooperatives (those who cultivate more than 100 decares or 10 hectares) may enjoy economies of scale (FAO 2003, MAFS 2004). But the number of farms larger than 100 decares in the sample used in this study is just $11(0.85$ percent of the 1293). And for Bulgaria in general, the proportion of farms larger than 100 decares is less than 2 percent. Finally, consolidation initiatives concern primarily the small fragmented farms precisely because they are unable to explore economies of scale. Farm size can therefore be omitted from Equation (1). 


\section{Data}

\section{1 General Description}

The source of data for this study is the most recent Bulgarian household survey, the 2003 Multi-topic Household Survey (MHS). ${ }^{150}$ Funded entirely by the World Bank, the MHS was conducted in October - November 2003 by teams, specifically trained for the purpose, from the National Statistical Institute (NSI) of Bulgaria.

The MHS is a nationally representative, multi-purpose household survey which includes information on a series of subjects such as household composition, income, education, consumption, employment, loans and credits, use of agricultural land, and farm production. The survey sample is comprised of 3023 households ( 8250 individuals) from the 28 official districts in the country. For the purposes of this study, data were extracted from the survey modules dealing with agriculture, household characteristics, income, credits, and education, respectively.

The agriculture module includes characteristics such as ownership of farm land, size and location of plots, types of crops grown, amounts harvested, prices of sold produce, purposes for which the produce were used, ownership of machinery for agricultural purposes, expenditures for hiring labour, seeding, fertilizers, transportation, and other agricultural activities. Household characteristics include age, sex, ethnicity, residence, and employment of household members. Data is available on pre-tax regular and nonregular income where "regular income" refers to the sum of earnings from main and

${ }^{150}$ Electronic survey data were obtained from the National Statistical Institute in July, 2007. 
second job, unemployment benefits, retirement pensions, heir's pensions, disability and other pensions, family allowances and scholarships. "Non-regular income" includes earnings from the rental or sales of assets, inheritances, lottery winnings, and social transfers. The module on loans and credits includes data for the households' repayment of debts, loans, or credits for agricultural and other purposes and the education module provides detailed information on the level and type of education of all household members.

Because the interest of the study is in farm fragmentation, only those households who owned farmland were initially included in the working data set. ${ }^{151}$ According to the information in the agricultural module, 1736 of the 3023 households or 57.43 percent of the surveyed households owned farmland. Columns two and three of Table 5 summarize their characteristics.

As shown in Table 4, the median and mean size of the 1736 households who own farmland is 2.78 and 2 respectively, indicating a relatively small household size. ${ }^{152}$ The majority (three quarters) of the household heads are males. About 39 percent of the household heads are high school graduates and 32 percent completed six years of education (middle school graduates). Only slightly above 14 percent of farm owners completed higher education; about 15 percent completed only three years of education.

\footnotetext{
${ }^{151}$ The original intention was to include both households who own and/or rent farmland. However, from the total of 1759 households who reported to have farmland only 23 indicated that they rent that land. Since 23 is a relatively small subset it was excluded from the working data set.

${ }^{152}$ The overall average household size for the sample of 3023 is 2.54 .
} 
More than 63 percent of these households have income from sources other than from the production of their farm.

Table 5 summarizes the characteristics of the 1736 farms and Table 6 summarizes the distribution of farm sizes. Decares (daa) ${ }^{153}$ and hectares (ha) are the most commonly used units of land area measurement in Bulgaria. Since the MHS uses decares as the measurement unit for the size of plots, this unit will be used throughout the study as a measure of the area or size of plots and farms.

As shown in Table 5 (columns two and three), the average and median size of farms and parcels is relatively small, about 15 and 7.5 decares, respectively. According to the MHS data, the maximum number of parcels which compose a farm is seven. More than 25 percent of households do not cultivate their land. ${ }^{154}$ Only about 23 percent of farms use fertilizers and less than eight percent use machinery and means of transportation while working their farms. The majority of parcels are located in the village or town where the household resides; only about 30 percent are not located in the place of residence. This indicates that the distance from the homestead to the majority of parcels is relatively short.

Table 6 (columns two and three) shows that about 50 percent of households operate farms with size of up to 5 decares, 12.1 percent of households own farms of size 5 to 10 decares and about 16 percent of households operate farms of size 10 to 20 decares. In other

\footnotetext{
${ }^{153} 1$ Decare $\approx 1000$ sq. $\mathrm{m} ; 1$ Decare $\approx 0.25$ Acres; 1 Hectare $=10$ Decares; 1 Hectare $=2.5$ Acres

154 This finding is surprising and will be explained below.
} 
words, more than 78 percent of farms are small with a size of less than 20 decares - a size considered below the minimum to provide a livelihood (Crampton 1983, 186). 20.73 percent of households own farms in the range 20 to 100 decares and only 1.1 percent of households operate farms larger than 100 decares. Undoubtedly, these numbers display a heavily left-skewed distribution of farm sizes and indicate that, generally, households own relatively small areas of farmland.

\section{2 Determining the Level of Fragmentation}

The Simmons Index (SI) will be used here as the measure of land fragmentation. As defined in Section II of the essay:

$$
\mathbf{S I}=\sum_{\mathbf{i}} \mathbf{A}_{\mathbf{i}}{ }^{2} / \mathbf{A}^{2}
$$

$\mathrm{A}_{\mathrm{i}}$ is the area of the $i^{\text {th }}$ plot; $\mathrm{A}=\sum_{\mathrm{i}} \mathrm{A}_{\mathrm{i}}$ is the total farm size; and $\mathrm{i}=1,2, \ldots, \mathrm{m}$ where $\mathrm{m}$ is the number of plots a farm is composed of

The formula implies that the values of the SI can range from zero to one and as noted in Section II of the essay, a value of one will indicate that the household owns a single plot of land, meaning complete land consolidation. A value close to zero, on the other hand, will indicate extreme levels of fragmentation since SI approaches zero as the number of plots cultivated by each farm grows. Because the Simmons Index is sensitive to the number of plots and to dispersion in the size of the plots, the average number of plots will be used as an alternative measure of fragmentation. In addition, as discussed in Section II of the essay, the number of plots per farm is a measure used by some studies to estimate 
the level of fragmentation in Bulgaria. Therefore, its measurement in this study will provide means of comparison with the estimates of other studies.

Table 7 summarizes the measurements for the level of farmland fragmentation in Bulgaria derived from the MHS. Given that the Simmons Index takes the value of 1 when land is fully consolidated, the obtained median value of 0.94 and mean value of 0.82 for the Simmons index as calculated with the MHS data indicate relatively low levels of fragmentation. For about 42 percent of the households, the Simmons Index takes the value of one, indicating that 42 percent of the farms are completely consolidated. The lowest observed value for the Simmons Index is 0.23 and for only 13.42 percent of farms it is less than or equal to 0.5 . Overall, for more than 70.5 percent of farms, the index is above 0.7 .

Turning to the number of parcels, the most frequently observed value is one, which characterizes the farm holdings of approximately 42 percent of the households. The average number of parcels per farm is 2.065 with approximately 31 percent of households operating a farm consisting of two separate plots. Only about 27 percent of farms are made up of 3 or more (up to 7) plots of land. These figures support the earlier finding that the level of farm land fragmentation in the country is relatively low.

One of the major disadvantages that opponents ascribe to fragmentation is that it leads to increased costs due to waste in travel time between plots. The MHS data do not provide information on the precise distance of plots from the house or the distance between the 
plots. However, it does include information on whether the plots are located in or out of the households' city, town, or village. As shown in Table 7, 70.33 percent of the plots are located in the place of residence. In addition, it is important to indicate that, in the MHS data, the first of the maximum of 7 plots that a household can own is characterized as yard, which is the plot that is adjacent to the home of the household. In fact, 36.36 percent of the total of 3584 plots is described as yards, which means that these plots are at a zero distance from the household. About 76 percent of the households own yards. Furthermore, 26.04 percent of the farms consist only of one plot plus a yard. Therefore, it is reasonable to assume that for a considerable number of the households, the distance between their homestead and their plots is relatively small.

The finding that the level of farm fragmentation in Bulgaria is relatively low is somewhat surprising and interesting given the earlier review of the literature on fragmentation in the country. The MHS data shows that on average farms are composed of 2 plots of land, whereas Section II discussed that various studies estimate the average farm composition to be in the range of 4 to 11 plots. The result points to a radical decline in the level of fragmentation following the post-communist transition and examining the precise causes for this decline would be an interesting future contribution to the study of fragmentation.

One of the reasons for the differences in the conclusions with respect to the level of fragmentation in this study and those presented in some of the literature is perhaps the use of data. With the exception of Noev, Swinnen, and Vranken (2004) where 
fragmentation is measured for a sample of 1440 agricultural households, most studies simply divide the total number of plots in the country by the number of farms to obtain a national average of the number of plots per farm. ${ }^{155}$ Another reason could be the criteria for measurement of fragmentation. Nearly all studies, including those of the Ministry of Agriculture and Food Supply support their arguments for high levels of fragmentation with figures demonstrating the increase in the percentage of small farms and decrease in the size of parcels or farms that are owned or rented. ${ }^{156}$ In other words, the main criterion for fragmentation is the division of agricultural land in Bulgaria into small farms or simply the prevalence of small land ownership which, as discussed above, the MHS data certainly supports. However, as emphasized at the beginning of this essay, the issue of undersized farms should be treated as separate from the issue of fragmentation. Therefore, once again, this study draws attention to the need of establishing the right criterion for measuring farm fragmentation in Bulgaria. Furthermore, higher accuracy and therefore better assessment could be achieved if fragmentation is measured on a district by district basis — the MHS data shows that some districts, such as Dobrich and Pleven, are more fragmented than others, such as Sofia City and Varna (not shown here).

\footnotetext{
${ }^{155}$ As discussed in Section II, Noev, Swinnen, and Vranken find that in 2003 the average number of parcels per farm was 5.3, which is still considerably lower than the average of 11 to 15 parcels per farm in the precommunist period.

${ }^{156}$ Examples of such studies are the 2004 Annual Report of MAFS, Kabil (2003); Kasabov and Koritarova (2004) which are MAFS studies; Toshev (1937); Yanakieva (2003); Yanakieva et al. (2006). In addition to the figures demonstrating the prevalence of undersized farms, other studies such as Dirimanova (2005), Rembold (2003), and Sabates-Wheeler (2002) provide statistics for the average number of parcels per farm which range from 3 to 7 . However, as discussed in Section II of this essay, from the studies, it is not entirely clear how those statistics are obtained. Furthermore, Kopeva (2002) presents as measures of fragmentation the total number of land owners, total number of plots, and average size of plots for the country in general. In Kopeva (2000) fragmentation is defined as the "multiplicity of non-contiguous plots within single ownership" and is described as a traditional phenomenon in Bulgaria. While there is a reference to the small size of the average land holdings, figures supporting the above argument are not included in the study.
} 
Table 8 summarizes the general agricultural characteristics of Bulgaria. Since the MHS data was collected in 2003, the table was constructed using 2003 figures for Bulgaria. The population and population density have been steadily decreasing with the latter being 70.3 and considerably lower compared to the EU average of 115.5 (Yanakieva 2003). The rate of rural population decline is much higher - since 1972 population in rural areas has declined by more than 1 million people. ${ }^{157}$ As shown in the table, the total agricultural area comprises 52.1 percent of the national territory. Utilized agricultural area (UAA) and arable land comprise approximately 92 and 56 percent of the total agricultural area, respectively.

According to the Agricultural Census of 2003, the total number of land holdings in the country is 680000 with 668000 under the category of utilized agricultural area. The average size of utilized agricultural area is 44 decares per farm but it is important to note that the structure of agriculture in the country is bimodal - there is a large number of small holdings and a small number of very large holdings. Three-quarters of farms have no more than 10 decares of agricultural area, and together comprise less than 7 percent of the utilized agricultural area. On the other hand, about 3900 farms $(0.58$ percent of the total number of farms) have a size greater than 1000 decares, and occupy 76 percent of the total utilized agricultural area (MAFS 2004 Annual Agricultural Report, 11). Figure II.1 shows the distribution of holdings according to utilized agricultural area.

\footnotetext{
${ }^{157}$ According to the documents of The European Agricultural Fund for Rural Development (2007, 8-9) in 2001-2004, the average annual rate of rural population decline was -10.5 per 1000 (\%o ) compared to -2.1 $\%$ of urban.
} 
Figure II.1 Distribution of Holdings According to the UAA

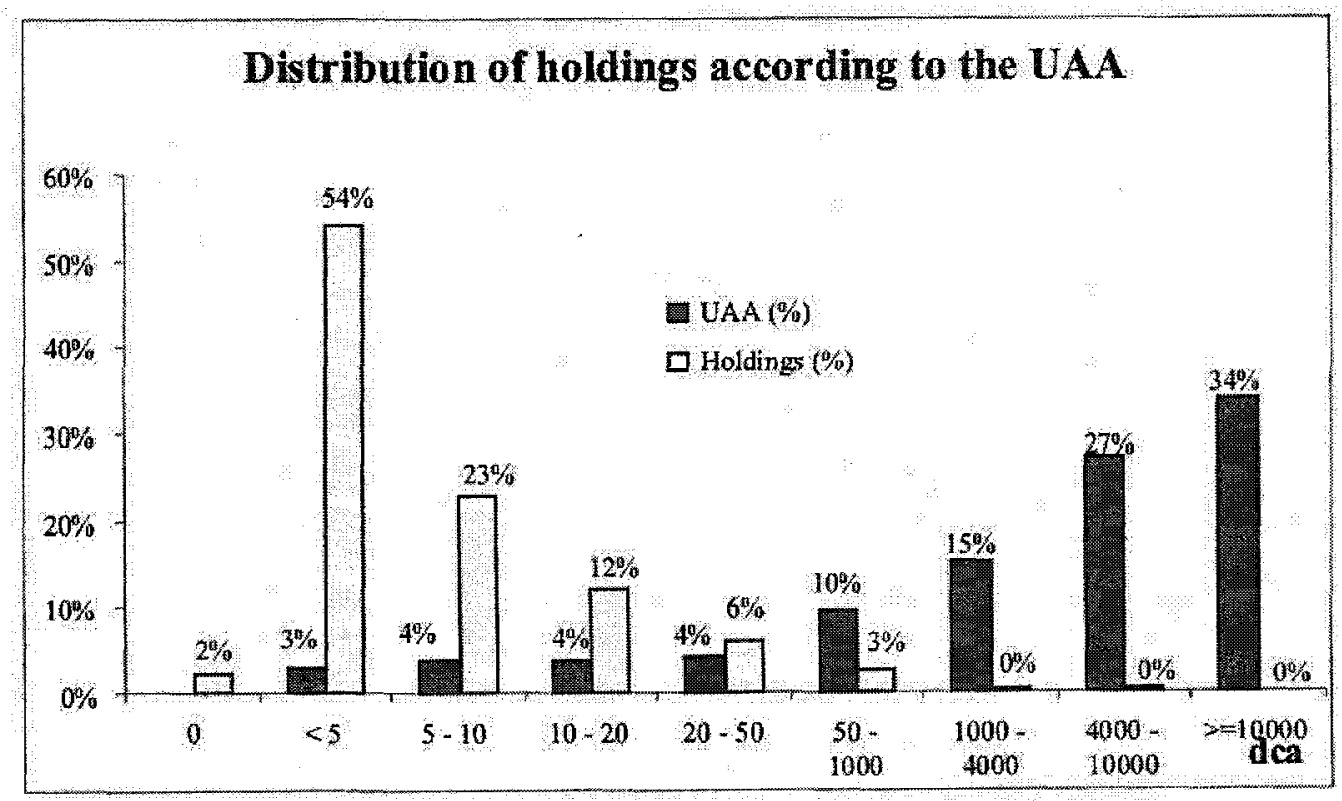

\section{Source: MAFS (2004). Annual Agricultural Report}

With respect to geographical characteristics, mountainous and semi-mountainous regions cover one-third of the country, interspersed with fertile valleys and plains. The climate ranges from moderate continental ${ }^{158}$ in the north to a Mediterranean ${ }^{159}$ in the south and districts are topographically heterogeneous with formations of combination of land types ranging from mountainous, semi-mountainous, coastal plains, plains, hilly plains, valleys, and hilly valleys. This allows for the production of variety of food and other crops, including cereals, oil crops such as sunflower, tobacco, and rose, forage plants, fruits and vegetables, and others.

\footnotetext{
${ }^{158}$ The continental climates are characterized with dry winters and wet summers.

${ }^{159}$ The Mediterranean climate features winters with moderate temperatures and changeable rainy weather while summers are hot and dry.
} 


\section{3 Further Description and Explanations of the MHS Data and Variables}

\section{Included in the Model}

A number of additional variables were derived from the MHS data in order to estimate the econometric model presented in Section III of the essay. This section of the essay will further specify the data content of the econometric model. A more detailed description of the procedures employed in deriving each variable is included in the Data Appendix.

The 2003 MHS data are well-suited to a statistical study of land fragmentation. It is a nationally representative data covering information for a sample of 3023 families from across the 28 districts of the country. Nonetheless, the nature of the data and the size of the sample require several compromises. As mentioned in Section IV. 1, 57.43 percent or 1736 of the households owned land. From the 1736 selected households, however, 440 (more than 25 percent of the sample) did not cultivate their lands. Seemingly surprising and unexpected, this result turned out to be a common feature for Bulgaria.

A consultation with Dr. I. Yanakieva of the Institute of Agricultural Economics in Sofia and D. Dimitrova of the National Statistical Institute in Sofia revealed that vast amounts of agricultural land in Bulgaria are left idle. Dr. Yanakieva explained that nationwide, the average amount of unused agricultural land is estimated at 45 percent of the total and in some districts it reaches 90 percent. Moreover, from 1989 to 2001 the amount of unused agricultural land has increased by more than 26 percent. ${ }^{160}$

\footnotetext{
${ }^{160}$ Dr. Yanakieva further explained that landowners leave their land idle for the following reasons: low market demand for agricultural products; low profitability of farm enterprises; difficulties in marketing and sale of agricultural produce; inability to finance the capital required to establish a farming business; unavailability of agricultural credits or difficulties in accessing credits; lack of tax on agricultural land.
} 
Since the goal is to test the impact of fragmentation on land productivity, the 440 households whose land was reported to be uncultivated must be excluded. With this exclusion, the sample size declines to 1296 farms. Furthermore, the sample contained three farms, the sizes of which $(600,800$, and 1200 decares) were considerably larger than the average farm size of 14.92 decares. ${ }^{161}$ These large farms were excluded as outliers so that the sample used in the econometric model includes 1293 farms.

Columns four and five of Table 4 summarize the characteristics of the 1293 households. It is interesting to note that the percentage of household heads with post-secondary and secondary education is smaller when those not cultivating their land are excluded by 3.34 and 2.24 , respectively. The figures imply that people with higher education are more likely to leave their land uncultivated which is in line with the explanations provided by Dimitrova and Yanakieva.

Table 5 (columns four and five) summarizes the characteristics of the 1293 farm households. A comparison of the two groups shows that more than 73 percent of the households who do not cultivate their land own farms composed of just one plot of land.

Furthermore, D. Dimitrova of the NSI explained that (1) the inheritance of small parcels of land discourages the involvement of individuals in the farming sector; (2) many post-restitution land owners are not qualified for, nor interested in farming; (3) lack of machinery and technology to cultivate the land the support provided by the European Union's Special Accession Programme for Agricultural and Rural Development (SAPARD) seem to be insufficient thereby still requiring investment on behalf of owners who do not have the necessary financial resources; and (4) the unfavourable work and labour conditions in the countryside, as well as the low profitability of farm enterprises discourage people, particularly youth, from getting involved in agricultural activity. All of this raises the question of why in such a case land is not sold or rented to interested parties. Dr. Yanakieva added that since there is no tax on land, there is no direct cost to holding the land idle. Many landowners simply wait for an increase in the value of their land expected to follow after accession to the EU. Source: Interviews by the author in Sofia in July, 2007 and further email conversations.

${ }^{161}$ It is interesting to note that these three large farms were not fragmented; they consisted of one single plot. 
Therefore, it is not surprising that both the mean and median values of the Simmons Index are now lower compared to the sample of 1736. In other words, the farms of the sample of households which own and cultivate their land is more fragmented compared to the farms of the sample which included those who own but do not cultivate their land. On the other hand, the percentage of farms located in the vicinity of the village or town of residence increased to about $\mathbf{8 1}$ percent which implies that for a considerable majority of households distance and therefore travel time to parcels should not be of much concern.

Table 6 (columns four, five, and six) presents the distribution of farms in the sample of the model. The table shows that majority of farms are no larger than 5 decares and only two of the farms are larger than 150 decares. Referring to the figures for the sample of 1736 , the largest decrease is in the number of farms smaller than 5 decares indicating that most of the 440 households who choose to leave their land idle are small farms.

The level of fragmentation for the 1293 farms is shown in Table 7. As indicated earlier, the overall fragmentation level is higher for this sample with the percentage of completely consolidated farms now being 31.32 . Nonetheless, for about 55 percent of farms, the Simmons Index is higher than 0.8 indicating a relatively low level of fragmentation overall.

Turning to the variables defined and used in the model, Table 9 lists them and describes their characteristics. The econometric model described in Section III is developed based on these variables. A detailed description of the procedures employed in deriving each 
variable is provided in the Data Appendix to this essay. The values of most of the variables of the model are not readily available in the MHS. Therefore, to derive those variables, a series of selection techniques, conversions, transformations, and computations was required. For example, the dependent variable of the model, land productivity $\mathrm{Y}_{\mathrm{i}}$, is measured as the total value of all harvested crops divided by the total planted area of these crops. In order to obtain this variable, a complicated calculation involving reported prices and outputs for 19 crops was performed (for more details refer to the Data Appendix).

One issue of concern may be the variable 'area devoted to crop' which is included in equation (7) of the econometric model. Area devoted to crop refers to the area of the farm which is under cultivation. Theoretically, it seems highly related to farm size. In fact, one would expect that it is equal or close to farm size raising the impression that farm size is being inappropriately included in the productivity equation under the name "area devoted to crop." However, close examination of the sample reveals that only 289 of the households (22.35 percent) actually cultivate the whole area of their farms and that the majority of these farms are smaller than 0.5 decares. The larger the farm, the smaller is the area cultivated and while the average farms size is 12.41 decares, average cultivated area is just 2.57 decares. ${ }^{162}$

\footnotetext{
${ }^{162}$ Furthermore, area devoted to crop is of interest to this study due to its specific dynamics given the prevalence of subsistence farming in Bulgaria. The MHS data shows and the literature indicates that majority of landholders do not sell their produce in the market. Rather, they use it for consumption, for payments in kind, to feed animals, exchange with neighbours and relatives, and as canned food for winter consumption. Therefore, area devoted to crop is a variable determined by the family by taking into account its annual needs for consumption. If the family has a small farm size, then area devoted to crop will obviously be large in relation to farm size, perhaps very close to farm size. The impact of the area devoted to crop on productivity, however, would not be due to economies of scale but due to the family's survival
} 
It may also be necessary to address the potential problems of inclusion of multiple crops. One possibility is to run separate regression for each crop pattern and the other is to aggregate several crop patterns into one. The second approach will be used in this study with land productivity measured as the total value of all crops divided by the total planted area of these crops. This approach can be supported by the fact that it is generally not possible to determine the corresponding multiple crop areas in a single parcel — separate regressions for each cropping pattern will produce small sample sizes. Aggregated regressions, as opposed to separate regressions will also capture the effects created by farmers switching to more profitable crops.

or consumption motives. And as will be seen in the results section, the relationship between area devoted to crop and productivity is negative and significant. 


\section{Estimation and Results}

The model was estimated using the "ivreg" command of Stata with robust standard errors. As explained in Section III of the essay, the first step is to estimate equation (6) of the model.

$$
F_{j}=b_{1} X_{2 j}+b_{2} X_{3 j}+e_{j} \quad j=1,2, \ldots m
$$

Recall that in this equation $\mathrm{F}_{\mathrm{j}}$ is the number of parcels in the $j^{\text {th }}$ household; $\mathrm{X}_{2 \mathrm{j}}$ is a vector of household-level explanatory variables; and $\mathrm{X}_{3 \mathrm{j}}$ is the vector of district-level variables. The explanatory variables represented by $\mathrm{X}_{2 \mathrm{j}}$ include household size, gender and formal education of the household head, inherited farm size, and distance from homestead to parcels. The explanatory variable $\mathrm{X}_{3 \mathrm{j}}$ represents the district-specific characteristics of the parcels associated with the $j^{\text {th }}$ household.

Table 10 summarizes the results of the first-stage regression and Table 11 presents the results of the second-stage regression when the number of parcels per holding is used as the measure of fragmentation. The values of R-squared and adjusted R-squared reported in Table 10 indicate that, overall, the estimated model fits the data well. Moreover, the Fstatistic of 66.57 shows that the overall fit of the estimated equation is statistically significant. 
With respect to variables, the first-stage results indicate that, as expected, the instrumental variable farm size is positively related to - and has a statistically significant effect on — the level of fragmentation. If the majority of farms are inherited, as was assumed in Section III due to the restitution process, current farm size can be assumed to be inherited farm size. In such a case, the results will support the supply-side explanations for fragmentation. On the other hand, area devoted to crops, distance to parcels, and use of fertilizers are also positive and statistically significant. These outcomes give credence to the demand-side explanations. Finally, 11 of the 28 district variables are statistically significant with 7 having positive signs. This indicates that, depending on the nature of district characteristics, either supply-side or demand-side factors may influence the level of fragmentation.

Similar results (shown in Tables 12 and 13) for the effects of these variables (farm size, area devoted to crops, distance to parcels, use of fertilizers, and 11 district variables) are obtained when using the Simmons Index as the measure of fragmentation. Note that the same variables are statistically significant but all have opposite signs compared to Tables 10 and 11. However, recall that a higher value for the Simmons Index indicates a lower level of fragmentation. Therefore, similar to the case when the number of parcels is used, the statistically significant variables have a positive effect on the level of fragmentation. The problem with this model is its explanatory power. Although the F-statistic of 14.06 shows that the overall fit of the estimated equation is statistically significant, the estimated model does not fit the data as well as the first model does. The R-squared of 0.27 indicates a relatively low correlation between the fitted and actual values of 
fragmentation. Moreover, farm size does not appear to be a very strong instrument when the Simmons Index is used as a measure of fragmentation.

Proceeding to the second stage, the goal is to estimate the effect of fragmentation on land productivity using Equation (7) of Section III:

$$
\log Y_{i j}=\alpha V_{k}+\beta_{1} \log X_{1 i j}+\beta_{2} \log X_{2 i j}+\beta_{3} \hat{F}_{i j}+\mu_{j}+e_{i j}
$$

As discussed earlier in the essay, the "accepted wisdom" is that fragmentation has a negative impact on productivity. Therefore, the null hypothesis is set to state that fragmentation has a coefficient less than or equal to zero:

$$
\begin{aligned}
& \mathrm{H}_{0}: \beta_{3}<=0 \\
& \mathrm{H}_{\mathrm{A}}: \beta_{3}>0
\end{aligned}
$$

This means that the null hypothesis can only be rejected if the coefficient on fragmentation is a positive and significant one. As noted by Blarel et al. (1992), rejection of this hypothesis would not prove that fragmentation arises because of demand. Rather, it would only contribute to the demand-side explanations along with other possible factors explaining the lack of negative relation between fragmentation and yield.

Table 11 shows the second-stage regression results when fragmentation is measured by the number of parcels are used. The coefficient on fragmentation is positive and 
significant. Therefore, the null hypothesis that fragmentation negatively affects yields is rejected.

Household size is significantly and positively related to yield. This result was expected since the more people the household has, the higher is the likelihood that more labour time would be invested in farming without the need to hire outside labour. The survey data shows that, in general, households do not hire labour and prefer to work the land on their own.

Similarly, the use of fertilizers and transportation are positively and significantly related to yield. This is again not surprising given that fertilizers enhance the natural fertility of the soil and therefore are expected to increase crop production levels. Higher levels of transportation help in travelling to plots, carrying equipment for tillage, planting, harvesting, storage, and sale of produce, transporting fertilizers, pesticides, insecticides and well as providing convenience, mobility, and flexibility. In other words, it affects productivity by allowing for more efficient use of valuable resources. "Distance to homestead" is also positively and significantly related to yield. Since distance was specified as a dummy variable (indicator 1 for parcels in residence and indicator 0 for parcels out of residence) the results imply that productivity is higher for those parcels located in the immediate or close vicinity of the place of residence. Naturally, a household can more efficiently manage and operate land which is close to their home. 
Finally, the area devoted to crop is significantly but negatively related to yield which means that the larger the area cultivated, the lower is productivity. This can be explained as follows. First, it is known that the soil on a given plot of land is not equally fertile or favourable for growing crops. Therefore, cultivating a greater area of that plot will reduce the output per unit decare. Second, the larger is the area cultivated, the larger is the likelihood of loss of output due to infestation or other natural hazards. Such cases, which are common in agriculture, will reduce the output per unit decare. And third, the survey data indicates that very few farmers sell their produce in the market which implies that they are interested in growing as much as is necessary for their personal needs. Given that a farmer's objective is to produce for his family consumption, he would only work to obtain this desired level of produce. If his land is small in size, then the farmer is expected to engage in some productivity-enhancing activities (more use of labour, or fertilizers, for example) to obtain the desired amount, thereby pushing output per unit up. Perhaps that explains the demand for fragmentation: it allows picking the best spots for different crops. Similarly, the farmer would not put any effort to increase productivity when he has a larger available land area which assures that the desired amount will easily be obtained without much productivity-enhancing activity, thereby lowering the output per unit.

The rest of the variables - gender of the household head, education, use of machinery, and non-farm income - have no significant effect on yield. Eleven district variables in Table 11 are significantly and negatively related to productivity. 


\section{Conclusion}

The following conclusions are derived from the discussions in sections III, IV, and V of the essay. First, the nationally representative MHS data demonstrates that fragmentation in Bulgaria is present, but its average level is low and it is considerably lower than the estimates provided in the literature for the pre-communist period. Second, as the data showed and as confirmed in interviews with Bulgarian specialists in the field, significant numbers of households in the country do not cultivate their lands for a number of reasons not related to fragmentation and among which the most important are those presented by the markets for credit and land. This implies that amount of land farmed may be increased through policies targeting improvement in the markets for credit and land which in turn can increase agricultural and land productivity. Third, the multiple regression analysis showed that the level of fragmentation in 2003 was not likely to adversely affect productivity. This is the main econometric finding of the essay which brings into question the plausibility of consolidation policies considered as a solution to improve land productivity. Other things being equal, consolidation policies are unlikely to improve land productivity in Bulgaria. It is possible that some districts in the country

may be more fragmented than others and so in such districts negative effects of fragmentation on productivity may be a matter of concern. This can be further investigated by measuring the impacts of fragmentation on a district by district basis. Consolidation policies, if desired by farmers, may be considered as a solution if evidence is presented that fragmentation adversely affects productivity in certain districts. 
Furthermore, the cost of travel time, most often attributed to fragmentation, seems to be a matter of concern given that distance to parcels seems to significantly affect productivity. However, a considerable majority of parcels are closely located to the household's homestead. In addition, distance from home to parcels seems to negatively affect the level of fragmentation implying that the shorter the distance, the more likely is that fragmentation will occur.

The most important message of this essay is that fragmentation in Bulgaria at present is not the problem that most researchers think it is. Insofar the level of fragmentation is of concern, it is often said that the radical reform initiated at the outset of the transition from a socialist to a capitalist economy brought the country back to a stage similar to the one where it was before the communist regime. The study shows that this is not the case; the current level of fragmentation is much lower than that of the pre-communist regime. The prevalence of undersized farms may be a problem but policymakers should be sure to be clear about which problem they are addressing. Better understanding of the underlying causes for the current problems in relation to land productivity is necessary in order to target correctly the areas which require policy intervention. Focusing on fragmentation as the major issue would be incorrect.

The essay has several implications for the Page: 206study of fragmentation. The most important contribution to the debate documented in the review of the literature is the conclusion that partible inheritance and population growth may not be the factors that drive fragmentation as is often assumed in the literature. Government intervention 
through egalitarian policies may lead to division of land into small farms but may only be limited to indirectly influencing fragmentation. Another interesting contribution is the finding that there is a significant decline in the level of fragmentation in the postcommunist period. This is in contrast to the argument in most of the studies that restitution of land brought back the pre-1944 level of fragmentation. A future research on the causes of this decline would prove useful in our understanding of the evolution of fragmentation. A comparison with other countries in transition would further contribute to the study of fragmentation. Last but not least, the study draws attention to an important issue in the literature: there must be achieved a consistency in the conceptualization and measurement of fragmentation if we are to assess accurately the nature of fragmentation and its impacts on economic outcomes. Researchers and policy makers should distinguish clearly the issue of undersized farms from the issue of having numerous parcels per farm. The essay clearly shows that they do not go hand in hand as is often assumed; it also points that the two issues differ in their advantages and disadvantages as well as in their possible impacts on economic outcomes.

Finally, for the case of Bulgaria in particular, the study is most likely the first to attempt to measure fragmentation by one of the indices developed for the purpose and by using a nationally representative survey data. It is also most likely the first to attempt to estimate the impact of fragmentation on land productivity in the country by using multiple regression analysis. The study can be improved in several ways. First, a more accurate picture of the level of fragmentation may be obtained by its measurement on a district by district basis. Such measurement would help in identifying the districts with higher or 
lower fragmentation. This in turn would allow for further studying the district specific supply-side or demand-side causes of fragmentation. It will also allow for using the model to estimate the impact of fragmentation on land productivity in a specific district and therefore the consideration of consolidation policies in districts where this impact appears to be negative. On the other hand, a nationally representative survey data may not be the ideal one to measure fragmentation and estimate its impacts. A qualitative survey of farms in different districts may prove more useful in the more accurate assessment of fragmentation. 


\section{References}

Bell, John D. 1977. Peasants in Power. Princeton: Princeton University Press.

Bentley, Jeffery W. 1987. Economic and Ecological Approaches to Land Fragmentation: In Defense of a Much-Maligned Phenomenon. Annual Review of Anthropology 16: 3167.

Berov, Lyuben. 1981. "Ikonomicheskoto razvitie na B"Igariya ot Osvobozhdenieto do kraya na XIX v." In Stopanska Istoriya na B"lgariya 681-1981, ed. Dimit"r Angelov, Nikolay Todorov, Bistra Tsvetkova, Stefan Tsonev, Lyuben Berov, Velizar Velkov, Lalyu Radulov, Georgi Petrov, Dimit"r Vasilev, Stefan Tsankov, Tasho Pachev, Mito Isusov, Gatyu Gatev, Radi Radev, and David Koen, 217-262. Sofia: D"rzhavno izdatelstvo nauka i izkustvo.

Berov, Lyuben. 1984. "Promeni v razpredelenieto na pozemlenata sobstvenost v Severna B"lgariya prez p"rvite dve desetiletiya sled Osvobozhdenieto. In Iz istoriyata na stopanskiya i sotsialniya zhivot v B"lgarskite zemi, ed. Khristo Khristov, 224-273. Sofia: Izdatelstvo na B"lgarskata akademiya na naukite.

Binns, Bernard O. 1950. The Consolidation of Fragmented Agricultural Holdings. Washington D.C.: FAO Agricultural Studies 11.

Bishop, S. C., Keith S. Howe, Diana Kopeva, and P. Mishev. 1995. "Formi na Sobstvenost i Pazari na Zemiata. In Reformata v Selskoto Stopanstvo, ed. Allan Buckwell, Andrew Schmitz, Kirby Moulton, Rangel Trendafilov, and Sofia Davidova, 89-100. Sofia: IPK Racio-90.

Blarel, Benoit, Peter Hazell, Frank Place, and John Quiggin. 1992. The Economics of Farm Fragmentation: Evidence from Ghana and Rwanda. World Bank Economic Review $6(2): 233-254$.

Brown, James F. 1970. Bulgaria under Communist Rule. New York: Praeger.

Bulgaria Ministry of Agriculture and Food Supply (MAFS). 2004. Annual Agricultural Report 2004. Section A: 1-277.

Bulgaria Ministry of Agriculture and Food Supply (MAFS). 2005. Annual Agricultural Report 2005. Section A: 1-277.

Bulgaria Ministry of Agriculture and Food Supply (MAFS). 2007. National Strategy Plan for Rural Development (2007-2013). Under the European Union Special Accession Program for Agriculture and Rural Development (SAPARD): 1-46. 
Bulgaria Bulgarian National Bank. Exchange Rates of Foreign Currencies against the Bulgarian Lev.

http://www.bnb.bg/bnb/home.nsf/fsWebIndex?OpenFrameset

Bulgaria National Statistical Institute. Census 2001 Final Results.

http://www.nsi.bg/Census_e/Census_e.htm

Bulgaria .1909. [Statistical Yearbook of the Kingdom of Bulgaria.] Statisticheski godishnik na Tsartsvo B"'lgariya. Sofiya: D"rzhavna pechatnitsa.

Bulgaria .1915. [Statistical Yearbook of the Kingdom of Bulgaria.] Statisticheski godishnik na Tsartsvo B"lgariya. Sofiya: D"rzhavna pechatnitsa.

Bulgaria .1935. [Statistical Yearbook of the Kingdom of Bulgaria.] Statisticheski godishnik na Tsartsvo B"lgariya. Sofiya: D"rzhavna pechatnitsa.

Bulgaria .1939. [Statistical Yearbook of the Kingdom of Bulgaria.] Statisticheski godishnik na Tsartsvo B"'lgariya. Sofiya: D"rzhavna pechatnitsa.

Crampton, Richard J. 1997. A Concise History of Bulgaria. Cambridge: Cambridge University Press.

Dahlman, Carl J. 1980. The Open Field System and Beyond. Cambridge: Cambridge University Press.

Dirimanova, Violeta. 2005. Land Market with Fragmented Landownership Rights in Bulgaria: An Institutional Approach. Paper presented at the $94^{\text {th }}$ EAAE Seminar. April 910, 2005. Imperial College, Why Campus, Ashford, UK.

Dolinsky, N. V. 1932. Difficulties in Bulgarian Farming. Journal of Farm Economics 14 (2): $355-358$.

Draganova, Slavka T. 2005. Selskoto naselenie na Dunavski vilaet. Sofia: Avangard Prima.

Dräger, Dieter and Tanja Jaksch. 2001. "Bulgaria." In Agricultural Transformation and Land Use in Central and Eastern Europe, ed. Stephan J. Goetz, Tanja Jaksch, and Rosemarie Siebert, 177-195. Burlington, VT: Ashgate.

FAO. 2003. "What is Land Consolidation?" In The Design of Land Consolidation Pilot Projects in Central and Eastern Europe. Land Tenure Studies 6. Rome: Food and Agriculture Organization of the United Nations (FAO). http://www.fao.org/DOCREP/006/Y4954E/y4954e06.htm\#bm06

Fenoaltea, Stefano. 1976. Risk, Transaction Costs, and the Organization of Medieval Agriculture. Explorations in Economic History 13 (2): 129-151. 
Fenoaltea, Stefano. 1977. Fenoaltea on Open Fields: A Reply. Explorations in Economic History 14 (4): 405-410.

Georgiev, Minko and Ivan Penov. 2006. Vliyanie na razhodite po prehv"rlyane na zemedelska zemya v"rhu konsolidatsiyata na pozemlenata sobstvenost. Ikonomika $i$ upravlenie na selskoto stopanstvo. 51 (3): 19-26.

Gonzalez, X. P., C. J. Alvarez, and R. Crecente. 2004. Evaluation of land distributions with joint regard to plot size and shape. Agricultural Systems 82 (1): 31-43.

Gonzalez, X. P., M. F. Marey, and C. J. Alvarez. 2007. Evaluation of productive rural land patterns with joint regard to the size, shape and dispersion of plots. Agricultural Systems 92 (1-3): 52-62.

Heston, Alan and Dharma Kumar. 1983. The Persistence of Land Fragmentation in Peasant Agriculture: An Analysis of South Asian Cases. Explorations in Economic History 20 (2): 199-220.

Homans, George C. 1937. Partible Inheritance of Villagers' Holdings. The Economic History Review 8 (1): 48-56.

Howe, Keith S. 1998. "Politics, equity, and efficiency: Objectives and outcomes in Bulgarian land reform." In Land Reform in the Former Soviet Union and Eastern Europe, ed. Stephen K. Wegren, 208-223. New York: Routledge.

Hung, Pham Van, T. Gordon MacAulay, and Sally P. Marsh. 2007. The economics of land fragmentation in the north of Vietnam. Australian Journal of Agricultural and Resource Economics 51 (2): 195-211.

Igbozurike, Matthias U. 1970. Fragmentation in Tropical Agriculture: An Overrated Phenomenon. The Professional Geographer 22 (6): 321-325.

Igbozurike, Mathias U. 1974. Land tenure, social relations and the analysis of special discontinuity. Area 6 (2): 132-136.

Ivanov, Martin and Adam Tooze. 2007. Convergence or Decline on Europe's Southeastern Periphery? Agriculture, Population, and GNP in Bulgaria, 1892-1945. The Journal of Economic History 67 (3): 672-704.

Jabarin Amer, S. and Francis M. Epplin. 1994. Impact of Land Fragmentation on the Cost of Production Wheat in the Rain-fed Region of Northern Jordan. Agricultural Economics $11(2-3): 191-196$.

Januszewski, Jozef. 1968. Index of Land Consolidation as a Criterion of the Degree of Concentration. Geographia Polonica 14:291-296. 
Jha, Raghbendra, Hari K. Nagarajan, and Subbarayan Prasanna. 2005. Land Fragmentation and its Implications for Productivity: Evidence from Southern India. ASARC Working Paper 2005/01. Australia South Asia Research Centre, Australian National University. http://rspas.anu.edu.au/papers/asarc/WP2005 01.pdf

Kabil, Nihat. 2004. Land Consolidation and Land Policy. Study of the Ministry of Agriculture and Forestry of Bulgaria presented at the Ministry of Agriculture and Forestry's Workshop "Land Consolidation and Land Policy in Bulgaria" held on 1-4 July 2004 in Plovdiv, Bulgaria.

Kasabov, Mihail and Violeta Koritarova. 2004. Bulgarian-Dutch Project for Land Consolidation. Study of the Ministry of Agriculture and Forestry of Bulgaria presented at the Ministry of Agriculture and Forestry's Workshop "Land Consolidation and Land Policy in Bulgaria" held on 1-4 July 2004 in Plovdiv, Bulgaria.

King, Russell L. and Steve P. Burton. 1982. Land Fragmentation: Notes on a Fundamental Rural Spatial Problem. Progress in Human Geography 6 (4): 475-494.

King, Russell L. and Steve P. Burton. 1983. Structural Change in Agriculture: The Geography of Land Consolidation. Progress in Human Geography 7 (4): 471-501.

Kopeva, Diana. 2000. Aspects of Land Consolidation in Bulgaria. FAO Comparative Study on Land Fragmentation in Four CEECs: Bulgaria, Czech Republic, Hungary and Romania. Sofia: Institute for Market Economics. http://www.ime-bg.org/pdf docs/papers/rural2000.pdf

Kopeva, Diana. 2001. "Land Markets in Bulgaria." In Land Settlement and Cooperatives. Land Reform 2003/3 Special Edition, 41-58: FAO. http://www.fao.org/docrep/006/y5026e/y5026e05.htm

Kopeva, Diana. 2002a. "Land Fragmentation and Land Consolidation in Bulgaria." Presentation at the International Symposium on Land Fragmentation and Land Consolidation in CEEC: A Gate towards Sustainable Rural Development in the New Millennium by FAO, GTZ, FIG, ARGE Landentwicklung and TUM. 25-28 February 2002, Munich, Germany.

Kopeva, Diana. 2002b. "Country Case Study: Land Markets in Bulgaria." Presentation at the World Bank Regional Workshop on Land Policy Issues: Central Europe and CIS. April 3-6, 2002. Budapest, Hungary.

Kopeva, Diana and Nivelin Noev. 2001. "Aspects of Land Consolidation after the Land Reform." In The New Structure of the Rural Economy of Post-communist Countries, ed. Osamu Ieda, 123-159. Sapporo: Hokkaido University. 
Kopeva, Diana, Nivelin Noev, and Vladimir Evtimov. 2002. Land Fragmentation and Land Consolidation in Bulgaria. Study commissioned by FAO.

http://www.landentwicklung-

muenchen.de/cd ceec conference/case studies/bulgaria/os o kopeva.pdf

Lampe, John R. and Marvin R. Jackson. 1982. Balkan Economic History, 1550-1950:

From Imperial Borderlands to Developing Nations. Bloomington: Indiana University Press.

Lerman, Zvi. 2005. Farm Fragmentation and Productivity: Evidence from Georgia.

Discussion Paper no. 8.05. Center for Agricultural Economic Research: The Hebrew University of Jerusalem.

http://departments.agri.huji.ac.il/economics/lerman-gru.pdf

McCloskey, Donald N. 1975a. "The Persistence of English Common Fields." In European peasants and their markets: essays in Agrarian economic history, ed. William N. Parker and Eric L. Jones, 73-119. Princeton: Princeton University Press.

McCloskey, Donald N. 1975b. "The economics of enclosure: A market analysis." In European peasants and their markets: essays in Agrarian economic history, ed. William N. Parker and Eric L. Jones, 123-160. Princeton: Princeton University Press.

McCloskey, Donald N. 1977. Fenoaltea on Open Fields: A Comment. Explorations in Economic History 14 (4): 402-404.

McIntyre, Robert J. 1988. Bulgaria: Politics, Economics and Society. London: Pinter.

McPherson, M.F. 1983. Land fragmentation in agriculture: Adverse? Beneficial? And for whom? Development Discussion Paper no. 145. Harvard Institute for International Development.

Meurs, Mieke. 2001. The Evolution of Agrarian Institutions: A Comparative Study of Post-Socialist Hungary and Bulgaria. Ann Arbor: University of Michigan Press.

Mouzelis, Nicos. 1976. Greek and Bulgarian Peasants: Aspects of Their Sociopolitical Situation during the Interwar Period. Comparative Studies in Society and History 18 (1): 85-105.

Nguyen, Tin, Enjiang Cheng, and Christopher Findlay. 1996. Land Fragmentation and Farm Productivity in China in the 1990s. China Economic Review 7 (2): 169-180.

Noev, Nivelin, Johan F. M. Swinnen, and Liesbet Vranken. 2004. The Development of Land Rental Markets in Bulgaria and the Former Yugoslav Republic of Macedonia. Research Group on Food Policy, Transition, and Development Working Paper 2004/1: Leuven: Katholieke Universiteit Leuven. http://ageconsearch.umn.edu/bitstream/31889/1/wp040001.pdf 
Pantev, Andrei. 1996. "The Historical Road of the Third Bulgarian State." In Bulgaria in a Time of Change: Economic and Political Dimensions, ed. Iliana Zloch-Christy, 7-19. Brookfield, VT: Ashgate.

Rembold, Fritz. 2003. "Land fragmentation and its impact in Central and Eastern European countries and the Commonwealth of Independent States." In Land Reform, Land Settlement and Cooperatives. Budapest: FAO Economic and Social Department. http://www.fao.org/docrep/005/Y8999T/y8999t0i.htm\#bm18

Risina, Mariya and Mimoza Mladenova. 2002. Po v"prosa za komasatsiyata na zemedelska zemya u nas. Ikonimka i upravlenie na selskoto stopanstvo 6:13-19.

Sabates-Wheeler, Rachel. 2002. Consolidation Initiatives after Land Reform: Responses to Multiple Dimensions of Land Fragmentation in Eastern European Agriculture. Journal of International Development 14 (7): 1005-1018.

Sabates-Wheeler, Rachel. 2005. Cooperation in the Romanian Countryside: An Insight into Post-Soviet Agriculture. Lanham, MD: Lexington Books.

Sanders, Irwin T. 1976. The Balkan Peasant Moves toward Industrialization. Proceedings of the Association of South-Eastern European Studies and UNESCO International Conference held on March 23-26, 1976 in Hamburg, Germany. Supplementary Issue of Balkanistica: $315-327$.

Schmook, G. Jr. 1976. “The spontaneous evolution from farming on scattered strips to farming in severality in Flanders between the sixteenth and twentieth centuries: a quantitative approach to the study of farm fragmentation." In Fields, Farms and Settlements in Europe, ed. R. H. Buchanan, R. A. Butlin, and D. McCourt, 107-117. Belfast: Ulster Folk and Transport Museum.

Sengupta, Nirmal. 2006. Fragmented landholding, productivity, and resilience management. Environment and Development Economics 11 (4): 507-532.

Simmons, A. Joyce. 1964. An Index of Farm Structure, with a Nottinghamshire Example. East Midlands Geographer 3:255-261.

Stoianovich, Traian. 1976. Balkan Peasants and Landlords and the Ottoman State: Familial Economy, Market Economy and Modernization. Proceedings of the Association of South-Eastern European Studies and UNESCO International Conference held on March 23-26, 1976 in Hamburg, Germany. Supplementary Issue of Balkanistica: 164204.

Strezov, G. 1913. Agrarniyat v"pros i pozemlenata sobstvenost v Nova B"lgariya. Sofia: Pechatnitsa Sv. Sofia. 
Sundqvist, Patrik and Lisa Andersson. 2006. A Study of the Impacts of Land Fragmentation on Agricultural Productivity in Northern Vietnam. Unpublished thesis. Uppsala: Uppsala University. http://publications.uu.se/abstract.xsql?dbid=7623

Tan, Shuhao, Futian Qu, and Nico Heerink. 2005. "What drives land fragmentation? Theoretical approaches and empirical analysis." In Developmental Dilemmas: Land Reform and Institutional Change in China, ed. Peter Ho, 201-229. New York: Routledge.

Thomas, Joachim. 2006. Property rights, land fragmentation and the emerging structure of agriculture in Central and Eastern European countries. The Electronic Journal of Agriculture and Development Economics 3 (2): 225-275.

ftp://ftp.fao.org/docrep/fao/009/ah757e/ah757e00.pdf

Todorova, Maria. 2002. Balkanskoto Semeystvo: Istoricheska demografiya na B'lgarskoto obshchestvo prez osmanskiya period. Sofia: Amicitia.

Todorova, Stela A. and Dimka Lulcheva. 2005. Economic and Social Effects of Land Fragmentation on Bulgarian Agriculture. Journal of Central European Agriculture 6 (4): $555-562$. http://www.agr.hr/jcea/issues/jcea6-4/pdf/jcea64-20.pdf

Toshev, Dako Iv. 1937. Razpredelenieto i komasatsiyata na zemite v B"lgariya. Sofia: Ministertsvo na zemedelieto i d"rzhavnite imoti.

Tsonev, Stefan A. 1948. V"znikvane i oformyavane na feodalizma v B"lgariya kato gospodstvuvashcha obshchestveno-ikonomicheska formatsiya. Varna: Universitetska Pechatnitsa.

Van Dijk, Terry. 2003. Scenarios of Central European land fragmentation. Land Use Policy 20 (2): 149-158.

Van Dijk, Terry and Diana Kopeva. 2006. Land banking and Central Europe: Future importance, current initiatives and Western European past experience.

Land use policy 23 (3): 286-301.

V'lchanov, Denyu. 1954. Istoriya na pozemlenite otnosheniya i zemeustroystvoto. Sofia: D"rzhavno izdatelstvo "Nauka i izkustvo."

V'lchev, Nikola. 1999. Agrarnata struktura na B"lgarskoto zemedelie. Sofia: Gorekspres.

Vladigerov, Todor A. 1942. Agrarni otnosheniya v B"lgariya: Etnografski svedeniya. Sofia: Godishnik na vissheto t"rgovsko uchilishche "Dimit"r A. Tsenov." 
Wakaley, Ray E. 1958. "Peasantisms." In Collectivization of Agriculture in Eastern Europe, ed. Irwin T. Sanders, 207-208. Lexington, KY: University of Kentucky Press.

Wan, Guang H. and Enjiang Cheng. 2001. Effects of Land Fragmentation and Returns to Scale in the Chinese Farming Sector. Applied Economics 33 (2): 183-194.

Yanakieva, Ivanka. 2003. "Land Tenure and Land Relations in Bulgaria." In An International Encyclopaedia of Land Tenure Relations for the Nations of the World, Volume 3, ed. Vladimir Belenkiy, 143-229. New York: The Edwin Mellen Press.

Yanakeva, Ivanka. 2006. Razmer i izpolzvane na zemedelskata zemya. In Problemi na sobstvenostta i polzvaneto na zemedelskata zemya b B'lgariya, ed. Ivanka Yanakieva, Maria Risina, Paunka Bozhinova, Dimit"r Dimitrov, and Mimoza Mladenova, 12-16. Sofia: PSSE.

Yovchevska, Plamena. 2002. Agrarnite otnosheniya v sledosvobozhdenska B"lgariya. Ikonomika i upravlenie na selskoto stopanstvo 3:41-44. 
Appendix of Tables for Essay II 
Table 1

Land Distribution in Bulgaria in 1897 and 1908

\begin{tabular}{|c|c|c|c|c|c|c|c|c|c|c|c|c|c|c|}
\hline \multirow{2}{*}{$\begin{array}{c}\text { Size of } \\
\text { holdings } \\
\text { (in decares) }\end{array}$} & \multicolumn{2}{|c|}{$\begin{array}{l}\text { Number of } \\
\text { holdings }\end{array}$} & \multicolumn{2}{|c|}{$\begin{array}{c}\text { Percent of } \\
\text { holdings }\end{array}$} & \multicolumn{2}{|c|}{ Number of decares } & \multicolumn{2}{|c|}{$\begin{array}{l}\text { Percent of } \\
\text { land }\end{array}$} & \multicolumn{2}{|c|}{ Number of parcels } & \multicolumn{2}{|c|}{$\begin{array}{c}\text { Average } \\
\text { number of } \\
\text { parcels }\end{array}$} & \multicolumn{2}{|c|}{$\begin{array}{l}\text { Percent of } \\
\text { parcels }\end{array}$} \\
\hline & 1897 & 1908 & 1897 & 1908 & 1897 & 1908 & 1897 & 1908 & 1897 & 1908 & 1897 & 1908 & 1897 & 1908 \\
\hline Less than 5 & 166,765 & 180,304 & 21 & 19 & $416,514.5$ & $462,317.4$ & 1 & 1 & 248,129 & 265,626 & 1.5 & 1 & 3 & 3 \\
\hline $5-10$ & 90,508 & 113,446 & 11 & 12 & $672,997.5$ & $837,482.1$ & 1.7 & 1.8 & 247,229 & 285,682 & 2.7 & 3 & 3 & 3 \\
\hline $10-20$ & 106,373 & 131,148 & 13 & 14 & $1,567,017.5$ & $1,915,877.8$ & 3.9 & 4.2 & 547,747 & 605,779 & 5.2 & 5 & 7 & 6 \\
\hline $20-30$ & 75,100 & 86,500 & 9 & 9 & $1,873,035$ & $2,149,450.4$ & 4.7 & 4.6 & 653,469 & 712,327 & 8.7 & 8 & 8 & 7 \\
\hline $30-40$ & 60,061 & 68,346 & 8 & 8 & $2,097,420.9$ & $2,385,067.2$ & 5.3 & 5.2 & 693,286 & 786,705 & 11.5 & 12 & 9 & 8 \\
\hline $40-50$ & 50,222 & 57,772 & 6 & 6 & $2,257,456.5$ & $2,595,848.8$ & 5.7 & 5.6 & 684,696 & 821,613 & 13.6 & 14 & 8 & 8 \\
\hline $50-75$ & 92,515 & 106,598 & 12 & 12 & $5,700,041.4$ & $6,573,162.1$ & 14.3 & 14.2 & $1,491,535$ & $1,845,748$ & 16.1 & 17 & 19 & 19 \\
\hline $75-100$ & 56,486 & 67,512 & 7 & 7 & $4,883,237$ & $5,845,011.5$ & 12.3 & 12.6 & $1,050,814$ & $1,394,259$ & 18.6 & 21 & 13 & 14 \\
\hline $100-150$ & 55,503 & 67,610 & 7 & 7 & $6,720,529.4$ & $8,186,693.6$ & 16.9 & 17.7 & $1,174,368$ & $1,595,903$ & 21.2 & 24 & 15 & 16 \\
\hline $150-200$ & 22,095 & 26,718 & 3 & 3 & $3,791,726.6$ & $4,583,088.5$ & 9.5 & 9.9 & 524,970 & 710,933 & 23.8 & 27 & 6 & 7 \\
\hline $200-300$ & 14,911 & 17,304 & 2 & 2 & $3,586,640.7$ & $4,123,931.6$ & 9 & 8.9 & 394,377 & 507,007 & 26.5 & 29 & 5 & 5 \\
\hline $300-400$ & 4,338 & 5,017 & 1 & 1 & $1,484,634$ & $1,715,590.1$ & 3.7 & 3.7 & 124,593 & 163,618 & 28.7 & 33 & 2 & 2 \\
\hline $400-500$ & 1,770 & 1,933 & .22 & .21 & $787,859.9$ & $862,008.4$ & 2 & 1.9 & 54,391 & 65,223 & 30.7 & 34 & 1 & 1 \\
\hline $500-1000$ & 1,993 & 2,223 & .25 & .24 & $1,338,862.2$ & $1,478,922.6$ & 3.4 & 3.2 & 61,798 & 77,891 & 31 & 35 & 1 & 1 \\
\hline $1000-2000$ & 606 & 592 & .08 & .06 & $826,002.6$ & $797,444.3$ & 2.1 & 1.7 & 19,001 & 22,507 & 31.4 & 38 & - & .23 \\
\hline $2000-3000$ & 155 & 154 & .02 & .02 & $377,793.1$ & $375,434.8$ & 1 & 0.8 & 5,900 & 7,031 & 38 & 46 & - & .07 \\
\hline $3000-5000$ & 100 & 99 & .01 & .01 & $427,364.2$ & 372,919 & 1.1 & 0.8 & 3,575 & 4,502 & 35.8 & 45 & - & .05 \\
\hline $\begin{array}{l}\text { More than } \\
5000\end{array}$ & 87 & 91 & .01 & .01 & $966,444.2$ & $997,618.8$ & 2.4 & 2.2 & 2,413 & 4,165 & 27.7 & 46 & - & .04 \\
\hline Total & $\mathbf{7 9 9 , 5 8 8}$ & 933,367 & 100 & 100 & $39,775,577$ & $46,257,869$ & 100 & 100 & $7,982,291$ & $9,876,519$ & 10 & 11 & 100 & 100 \\
\hline
\end{tabular}

Source: Statistical Yearbook of the Kingdom of Bulgaria $(1909,183 ; 1915,128-129)$ and author's own calculations. 
$\frac{a}{n}$

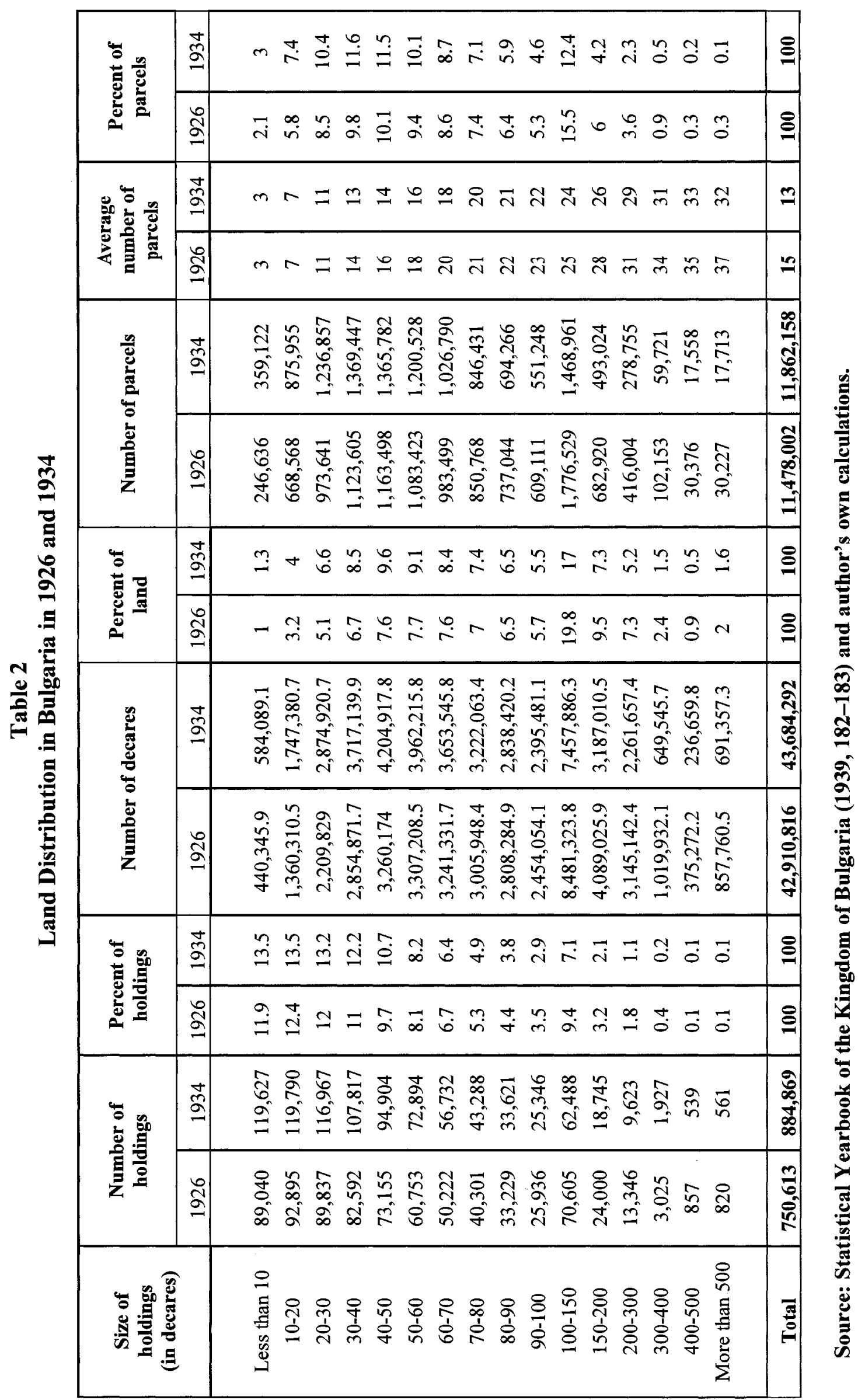


Table 3 Percentage Change in Land Distribution

\begin{tabular}{|c|c|c|c|c|c|c|c|c|c|}
\hline \multirow[t]{2}{*}{$\begin{array}{c}\text { Size of } \\
\text { holdings } \\
\text { (in decares) }\end{array}$} & \multicolumn{3}{|c|}{$\begin{array}{l}\text { Percentage change in the } \\
\text { number of holdings }\end{array}$} & \multicolumn{3}{|c|}{$\begin{array}{l}\text { Percentage change in the } \\
\text { number of parcels }\end{array}$} & \multicolumn{3}{|c|}{$\begin{array}{l}\text { Percentage change in the } \\
\text { average number of parcels }\end{array}$} \\
\hline & 1897-1908 & 1908-1926 & 1926-1934 & $1897-1908$ & 1908-1926 & 1926-1934 & $1897-1908$ & 1908-1926 & 1926-1934 \\
\hline $\begin{array}{c}\text { Less than } 10 \\
10-20 \\
20-30 \\
30-40 \\
40-50 \\
50-100 \\
100-150 \\
150-200 \\
200-300 \\
300-400 \\
400-500 \\
\text { More than } \\
500\end{array}$ & $\begin{array}{l}0.14 \\
0.23 \\
0.15 \\
0.14 \\
0.15 \\
0.17 \\
0.22 \\
0.21 \\
0.16 \\
0.16 \\
0.09\end{array}$ & $\begin{array}{c}-0.70 \\
-0.29 \\
0.04 \\
0.21 \\
0.27 \\
0.21 \\
0.04 \\
-0.10 \\
-0.23 \\
-0.40 \\
-0.56\end{array}$ & $\begin{array}{c}0.34 \\
0.29 \\
0.30 \\
0.31 \\
0.30 \\
0.10 \\
-0.11 \\
-0.22 \\
-0.28 \\
-0.36 \\
-0.37\end{array}$ & $\begin{array}{l}0.11 \\
0.11 \\
0.09 \\
0.13 \\
0.20 \\
0.27 \\
0.36 \\
0.35 \\
0.29 \\
0.31 \\
0.20\end{array}$ & $\begin{array}{c}-0.55 \\
0.10 \\
0.37 \\
0.43 \\
0.42 \\
0.32 \\
0.11 \\
-0.04 \\
-0.18 \\
-0.38 \\
-0.53\end{array}$ & $\begin{array}{l}0.46 \\
0.31 \\
0.27 \\
0.22 \\
0.17 \\
0.01 \\
-0.17 \\
-0.28 \\
-0.33 \\
-0.42 \\
-0.42\end{array}$ & $\begin{array}{l}-0.05 \\
-0.04 \\
-0.08 \\
0.04 \\
0.03 \\
0.09 \\
0.13 \\
0.13 \\
0.09 \\
0.15 \\
0.11\end{array}$ & $\begin{array}{l}0.50 \\
0.40 \\
0.38 \\
0.17 \\
0.14 \\
0.09 \\
0.04 \\
0.04 \\
0.07 \\
0.03 \\
0.03\end{array}$ & $\begin{array}{c}0.00 \\
0.00 \\
0.00 \\
-0.07 \\
-0.13 \\
0.01 \\
-0.04 \\
-0.07 \\
-0.06 \\
-0.09 \\
-0.06\end{array}$ \\
\hline $\begin{array}{l}\text { Overall } \\
\text { change }\end{array}$ & 0.17 & -0.20 & 0.18 & 0.24 & 0.16 & 0.03 & 0.10 & 0.36 & -0.13 \\
\hline
\end{tabular}

Source: Author's calculations based on the Statistical Yearbook of the Kingdom of Bulgaria (1909, 183; 1915, 128-129; 1939, 182-183). 
Table 4 Selected Household Characteristics for the Samples of 1736 and 1293 Households

\begin{tabular}{|c|c|c|c|c|}
\hline Description & $\begin{array}{l}\text { Households } \\
\text { who own } \\
\text { land }\end{array}$ & $\begin{array}{l}\text { Percentage } \\
\text { of the total } \\
\text { sample }\end{array}$ & $\begin{array}{l}\text { Households } \\
\text { who own } \\
\text { and } \\
\text { cultivate } \\
\text { their land } \\
\end{array}$ & $\begin{array}{l}\text { Percentage } \\
\text { of the total } \\
\text { sample }\end{array}$ \\
\hline Number of households & 1736 & 57.43 & 1293 & 42.77 \\
\hline Mean household size & 2.78 & & 2.84 & \\
\hline Median household size & 2 & & 2 & \\
\hline Gender of household's head & & & & \\
\hline Male & 1307 & 75.29 & 982 & 75.9 \\
\hline Female & 429 & 24.71 & 311 & 24.1 \\
\hline \multicolumn{5}{|l|}{$\begin{array}{l}\text { Highest level of education of } \\
\text { household's head }\end{array}$} \\
\hline Undergraduate or Graduate & 246 & 14.17 & 140 & 10.83 \\
\hline High school & 674 & 38.82 & 473 & 36.58 \\
\hline Middle school & 556 & 32.03 & 462 & 35.73 \\
\hline Elementary school & 260 & 14.98 & 218 & 16.86 \\
\hline $\begin{array}{l}\text { Households with non-farm } \\
\text { income }\end{array}$ & 1099 & 63.31 & 839 & 64.88 \\
\hline Mean non-farm income & $804.344^{163}$ & & 807.4 & \\
\hline Median non-farm income & 780 & & 780 & \\
\hline
\end{tabular}

Source: Author's calculations using the MHS data.

\footnotetext{
${ }^{163}$ All currency figures are in Bulgarian Leva (BGN). For 2003, 1 USD $\approx 1.715$ BGN, at a yearly average exchange rate (Bulgarian National Bank 2007). As of 31 May, 2008, 1 USD $\approx 1.074$ BGN.
} 
Table 5 Selected Farm Characteristics for the Samples of 1736 and 1293 Households

\begin{tabular}{|c|c|c|c|c|}
\hline Description & $\begin{array}{c}\text { Households } \\
\text { who own } \\
\text { land }\end{array}$ & $\begin{array}{c}\text { Percentage } \\
\text { of the total } \\
\text { sample }\end{array}$ & $\begin{array}{c}\text { Households } \\
\text { who own } \\
\text { and } \\
\text { cultivate } \\
\text { their land } \\
\end{array}$ & $\begin{array}{c}\text { Percentage } \\
\text { of the total } \\
\text { sample }\end{array}$ \\
\hline Number of households & 1736 & & 1293 & \\
\hline Median farm size (decares) & 5.2 & & 4.5 & \\
\hline Mean farm size (decares) & 14.92 & & 12.41 & \\
\hline $\begin{array}{l}\text { Number of farms composed of one } \\
\text { parcel }\end{array}$ & 731 & 42.11 & 405 & 31.32 \\
\hline $\begin{array}{l}\text { Number of farms composed of two } \\
\text { parcels }\end{array}$ & 532 & 30.65 & 449 & 34.73 \\
\hline $\begin{array}{l}\text { Number of farms composed of } \\
\text { three parcels }\end{array}$ & 266 & 15.32 & 242 & 18.72 \\
\hline $\begin{array}{l}\text { Number of farms composed of } \\
\text { four parcels }\end{array}$ & 116 & 6.68 & 108 & 8.35 \\
\hline $\begin{array}{l}\text { Number of farms composed of } \\
\text { five parcels }\end{array}$ & 45 & 2.59 & 44 & 3.4 \\
\hline $\begin{array}{l}\text { Number of farms composed of six } \\
\text { parcels }\end{array}$ & 20 & 1.15 & 19 & 1.47 \\
\hline $\begin{array}{l}\text { Number of farms composed of } \\
\text { seven parcels }\end{array}$ & 26 & 1.50 & 26 & 2.01 \\
\hline $\begin{array}{l}\text { Median number of parcels per } \\
\text { farm }\end{array}$ & 2 & & 2 & \\
\hline Mean number of parcels per farm & 2.065 & & 2.31 & \\
\hline Mean parcel size (decares) & 7.49 & & 4.63 & \\
\hline $\begin{array}{l}\text { Median Value of the Simmons } \\
\text { Index }\end{array}$ & 0.94 & & 0.85 & \\
\hline Mean Value of the Simmons Index & 0.82 & & 0.78 & \\
\hline $\begin{array}{l}\text { Lower bound of the Simmons } \\
\text { Index }\end{array}$ & 0.23 & & 0.23 & \\
\hline $\begin{array}{l}\text { Upper bound of the Simmons } \\
\text { Index }\end{array}$ & 1 & & 1 & \\
\hline $\begin{array}{l}\text { Number of farms which use } \\
\text { fertilizers }\end{array}$ & 397 & 22.87 & 389 & 30.09 \\
\hline $\begin{array}{l}\text { Number of farms which use } \\
\text { machinery }\end{array}$ & 137 & 7.89 & 132 & 10.21 \\
\hline $\begin{array}{l}\text { Number of farms which use } \\
\text { transportation }\end{array}$ & 138 & 7.95 & 128 & 9.9 \\
\hline $\begin{array}{l}\text { Number of parcels located in the } \\
\text { place of residence }\end{array}$ & 1221 & 70.33 & 1047 & 80.97 \\
\hline $\begin{array}{l}\text { Number of parcels located out of } \\
\text { the place of residence }\end{array}$ & 515 & 29.67 & 246 & 19.03 \\
\hline
\end{tabular}

Source: Author's calculations using the MHS data. 
Table 6 Distribution of Farm Size for the Samples of 1736 and 1293 Households

\begin{tabular}{|c|c|c|c|c|c|}
\hline $\begin{array}{c}\text { Range of Farm } \\
\text { Size (FS, } \\
\text { decares) for the } \\
\text { sample of } 1736\end{array}$ & $\begin{array}{l}\text { Number of } \\
\text { Households }\end{array}$ & $\begin{array}{l}\text { Percentage } \\
\text { of } \\
\text { Households }\end{array}$ & $\begin{array}{l}\text { Range of Farm } \\
\text { Size (FS, } \\
\text { decares) for the } \\
\text { sample of } 1293\end{array}$ & $\begin{array}{l}\text { Number of } \\
\text { Households }\end{array}$ & $\begin{array}{l}\text { Percentage } \\
\text { of } \\
\text { Households }\end{array}$ \\
\hline $\mathrm{FS}<=5$ & 865 & 49.83 & $\mathrm{FS}<=5$ & 682 & 52.75 \\
\hline $5<\mathrm{FS}<=10$ & 210 & 12.1 & $5<\mathrm{FS}<=10$ & 140 & 10.83 \\
\hline $10<\mathrm{FS}<=20$ & 282 & 16.24 & $10<\mathrm{FS}<=20$ & 195 & 15.08 \\
\hline $20<\mathrm{FS}<=30$ & 145 & 8.35 & $20<\mathrm{FS}<=30$ & 107 & 8.27 \\
\hline $30<\mathrm{FS}<=40$ & 100 & 5.76 & $30<\mathrm{FS}<=40$ & 73 & 5.65 \\
\hline $40<\mathrm{FS}<=50$ & 36 & 2.07 & $40<\mathrm{FS}<=50$ & 25 & 1.93 \\
\hline $50<\mathrm{FS}<=100$ & 79 & 4.55 & $50<\mathrm{FS}<=100$ & 60 & 4.64 \\
\hline $100<\mathrm{FS}<=150$ & 10 & 0.58 & $100<\mathrm{FS}<=150$ & 9 & 0.7 \\
\hline $150<\mathrm{FS}<=200$ & 2 & 0.12 & $\mathrm{FS}>150$ & 2 & 0.15 \\
\hline $\mathrm{FS}>200$ & 7 & 0.4 & & & \\
\hline $\begin{array}{l}\text { Median farm } \\
\text { size }=5.2\end{array}$ & & & $\begin{array}{l}\text { Median farm } \\
\text { size }=4.5\end{array}$ & & \\
\hline $\begin{array}{c}\text { Mean farm size } \\
=14.92\end{array}$ & & & $\begin{array}{c}\text { Mean farm size } \\
\quad=12.41\end{array}$ & & \\
\hline
\end{tabular}

Source: Author's calculations using the MHS data. 
Table 7 Fragmentation of Farmland in Bulgaria

\begin{tabular}{|c|c|c|c|c|c|}
\hline $\begin{array}{c}\text { Value or Range } \\
\text { of the Simmons } \\
\text { Index (SI) } \\
\text { for the sample of } \\
1736\end{array}$ & $\begin{array}{l}\text { Number of } \\
\text { Households }\end{array}$ & $\begin{array}{l}\text { Percentage } \\
\text { of } \\
\text { Households }\end{array}$ & $\begin{array}{l}\text { Value or Range of } \\
\text { the Simmons } \\
\text { Index (SD) for the } \\
\text { sample of } 1293\end{array}$ & $\begin{array}{l}\text { Number of } \\
\text { Households }\end{array}$ & $\begin{array}{c}\text { Percentage of } \\
\text { Households }\end{array}$ \\
\hline $\mathrm{SI}=0$ & 0 & 0 & $\mathrm{SI}=0$ & 0 & 0 \\
\hline $0<\mathrm{SI}<=0.1$ & 0 & 0 & $0<\mathrm{SI}<=0.1$ & 0 & 0 \\
\hline $0.1<\mathrm{SI}<=0.2$ & 0 & 0 & $0.1<\mathrm{SI}<=0.2$ & 0 & 0 \\
\hline $0.2<\mathrm{SI}<=0.3$ & 23 & 1.32 & $0.2<$ SI $<=0.3$ & 23 & 1.78 \\
\hline $0.3<\mathrm{SI}<=0.4$ & 72 & 4.15 & $0.3<$ SI $<=0.4$ & 70 & 5.41 \\
\hline $0.4<\mathrm{SI}<=0.5$ & 138 & 7.95 & $0.4<\mathrm{SI}<=0.5$ & 126 & 9.74 \\
\hline $0.5<\mathrm{SI}<=0.6$ & 159 & 9.16 & $0.5<\mathrm{SI}<=0.6$ & 137 & 10.6 \\
\hline $0.6<\mathrm{SI}<=0.7$ & 120 & 6.91 & $0.6<\mathrm{SI}<=0.7$ & 106 & 8.2 \\
\hline $0.7<\mathrm{SI}<=0.8$ & 134 & 7.72 & $0.7<\mathrm{SI}<=0.8$ & 121 & 9.36 \\
\hline $0.8<\mathrm{SI}<=0.9$ & 151 & 8.7 & $0.8<\mathrm{SI}<=0.9$ & 134 & 10.36 \\
\hline $0.9<$ SI $<1$ & 211 & 12.15 & $0.9<\mathrm{SI}<1$ & 171 & 13.23 \\
\hline $\begin{array}{c}\text { SI }=1 \\
\text { Median Value } \\
\text { of the SI }=0.94 \\
\text { Mean Value of } \\
\text { the SI }=0.82\end{array}$ & 728 & 41.94 & $\begin{array}{c}S I=1 \\
\text { Median Value of } \\
\text { the } S I=0.85 \\
\text { Mean Value of } \\
\text { the } S I=0.78\end{array}$ & 405 & 31.32 \\
\hline $\begin{array}{c}\text { Number of } \\
\text { Parcels }\end{array}$ & & & $\begin{array}{c}\text { Number of } \\
\text { Parcels }\end{array}$ & & \\
\hline 1 & 731 & 42.11 & $\overline{1}$ & 405 & 31.32 \\
\hline 2 & 532 & 30.65 & 2 & 449 & 34.73 \\
\hline 3 & 266 & 15.32 & 3 & 242 & 18.72 \\
\hline 4 & 116 & 6.68 & 4 & 108 & 8.35 \\
\hline 5 & 45 & 2.59 & 5 & 44 & 3.4 \\
\hline 6 & 20 & 1.15 & 6 & 19 & 1.47 \\
\hline 7 & 26 & 1.50 & 7 & 26 & 2.01 \\
\hline Median $=2$ & & & Median $=2$ & & \\
\hline Mean $=2.065$ & & & Mean $=2.31$ & & \\
\hline $\begin{array}{l}\text { Households } \\
\text { with parcels in } \\
\text { the place of } \\
\text { residence }\end{array}$ & 1221 & 70.33 & $\begin{array}{l}\text { Households with } \\
\text { parcels in the } \\
\text { place of } \\
\text { residence }\end{array}$ & 1047 & 80.97 \\
\hline $\begin{array}{l}\text { Households } \\
\text { with parcels } \\
\text { not in the place } \\
\text { of residence }\end{array}$ & 515 & 29.67 & $\begin{array}{l}\text { Households with } \\
\text { parcels not in the } \\
\text { place of } \\
\text { residence }\end{array}$ & 246 & 19.03 \\
\hline
\end{tabular}

Source: Author's calculations using the MHS data. 
Table 8 Selected Data Characteristics for Bulgaria

\begin{tabular}{|c|c|}
\hline Country Characteristics ${ }^{164}$ & \\
\hline Area* & $\begin{array}{l}110990 \mathrm{sq} . \mathrm{km} \\
11099000 \mathrm{ha}\end{array}$ \\
\hline Population** & 7932984 \\
\hline Population density per sq. km.** & 70.3 \\
\hline Population of rural areas*** & 3200000 \\
\hline Population density in rural areas $* * *$ & 35.8 \\
\hline Number of Districts** & 28 \\
\hline Total Number of Households** & 2921887 \\
\hline $\begin{array}{l}\text { Gross Domestic Product (GDP) for } 2003 \text { (million } \\
\text { BGN) }\end{array}$ & 34410 \\
\hline Gross Value Added (GVA) for 2003 (million BGN) & 30089 \\
\hline Share of the Agricultural Sector in 2003 GVA & $11.4 \%$ \\
\hline Total Agricultural Land (TAL) ${ }^{166}$ in 2003 & 5782000 ha \\
\hline TAL percentage of the National Territory & 52.1 \\
\hline Utilized Agricultural Area (UAA) ${ }^{167}$ in 2003 & 5326000 ha \\
\hline Arable (Cultivated) Land $d^{168}$ & 3239000 ha \\
\hline Total Number of Land Holdings with UAA & 668000 \\
\hline Average UAA Size per Farm & 44 decares \\
\hline
\end{tabular}

\section{Source: Various, see footnotes.}

164

* Source: MAFS 2004 Annual Agricultural Report (p. 2-15). Most of the data in the report are based on the Bulgarian Agricultural Census of 2003.

** Source: National Statistical Institute, Census 2001 Results

*** Source: The European Agricultural Fund for Rural Development $(2007,8)$

${ }^{165}$ GDP is calculated in 2003 market prices. GDP per capita is 4398 BGN or USD 2538 at an average exchange rate of $1 \mathrm{USD}=1.733 \mathrm{BGN}$.

${ }^{166}$ Total Agricultural Land includes utilized agricultural area and temporary uncultivated land such as perennials and fallow land stranded for more than 3 years and requiring very small investment to be reintroduced to crop rotation. Fallow land is either cultivated or stranded land which have not yield in the monitored year. Cultivated or otherwise, such areas may only stay in this item for no longer than three years (MAFS 2004 Agricultural Report, 5).

${ }^{167}$ Utilized Agricultural Area is defined as the land worked by a farm regardless of the form of property rented, leased, own, or other. It includes arable land, perennials, nurseries, kitchen gardens, meadows, and permanent grassland (p. 9).

${ }_{168}$ Arable or cultivated land is defined as a farmland placed in crop rotation every year and includes the areas under 1-year crops such as cereals, industrial forage crops, vegetables, and flowers; areas under berries, the oil rose, lavender, fallow land and land producing seed and seedlings (p. 10). 
Table 9 Characteristics of Variables Used in the Model

Variable Name

Dependent Variable

Productivity, $\mathrm{Y}_{\mathrm{i}}$

\section{Explanatory (Independent \\ Variables)}

\section{Parcel Specific Variables $\left(X_{I}\right)$}

Farm Fragmentation

Farm Size

Distance to Homestead

Area Devoted to Crops

Use of Fertilizers

Use of Machinery

Use of Transportation

\section{Household Specific Variables $\left(X_{2}\right)$}

Household Size

Gender of the Head of Household

\section{Variable Description} decare

Level of farm fragmentation defined at the household level and measured by (1) the Simmons Index and (2) by the number of parcels per farm

The sum of the total area of all parcels measured in decares

Dummy variable; $1-0$ indicator of the location of the parcel in- or outof the household's residence

Area of the parcel cultivated with crops measured in decares

Dummy variable; $1-0$ indicator of the use of fertilizer on the parcel

Dummy variable; $1-0$ indicator of the use of machinery on the parcel

Dummy variable; $1-0$ indicator of the use of transportation to and from the parcel
Mean

252.53

241.28

(1) 0.78

(2) 2.30

(1) 0.23

(2) 1.34

12.41

20.06

0.81

0.39

3.44

9.94

Standard

\section{eviation}

.39
94
46
303
3

0.76 
Table 9 Continued

Variable Name

Education Level of the Head of Household

Non-farm Income (BGN)

District Specific Variable $\left(X_{3}\right)$

\section{Variable Description}

Dummy variable; indicator 1 for graduate/undergraduate, 2 for high school, 3 for middle school; and 0 for elementary school or incomplete education

If applicable, measured as the sum of the following eight categories of regular income: second job earnings, unemployment benefits, retirement pension, heir's pension, disability pension, other pensions, family allowances, and scholarships

District dummy variable intended to capture the effects of prices, the efficiency of local land, labour, and credit markets, as well as the agro-climatic diversity; indicator 0 to 27 for the 28 districts listed in Cyrillic alphabetical order
Mean Standard

Deviation

$\begin{array}{ll}\text { (1) } 0.108 & \text { (1) } 0.311\end{array}$

$\begin{array}{ll}\text { (2) } 0.366 & \text { (2) } 0.482\end{array}$

$\begin{array}{ll}\text { (3) } 0.357 & \text { (3) } 0.479\end{array}$

$807.419 \quad 804.42$

$0.036^{169} \quad 0.184^{170}$

\section{Source: Author's calculations using the MHS data.}

\footnotetext{
169 The average of all 28 districts

${ }^{170}$ The average of all 28 districts
} 
Table 10 First-stage Regression Results

Number of parcels is used as the measure of fragmentation

Number of observations: $\quad 1293$

F (39, 1253): $\quad 66.57$

Prob > F: $\quad 0.0000$

R-squared: $\quad 0.6745$

Adjusted R-squared: $\quad 0.6644$

\begin{tabular}{|c|c|c|c|}
\hline Log Fragmentation & Coefficient & Std. Err. & $\mathrm{t}$ \\
\hline Log Farm Size & .2090596 & .0064776 & 32.27 \\
\hline Log Household Size & .0285554 & .017352 & 1.65 \\
\hline Log Area Devoted to Crops & .0234101 & .0080214 & 2.92 \\
\hline Distance & .1096218 & .0256386 & 4.28 \\
\hline Education 3 & .0010272 & .0271601 & 0.04 \\
\hline Education 2 & -.0287047 & .0282378 & -1.02 \\
\hline Education 1 & -.059684 & .0373486 & -1.60 \\
\hline Transportation & .0080558 & .0322299 & 0.25 \\
\hline Machinery & .0158826 & .0329948 & 0.48 \\
\hline Fertilizers & .0662392 & .023421 & 2.83 \\
\hline Non-farm Income & $3.74 \mathrm{e}-06$ & .0000114 & 0.33 \\
\hline Gender & -.0092166 & .0216112 & -0.43 \\
\hline Constant & .2551733 & .0729022 & 3.50 \\
\hline
\end{tabular}


Table 11 Second-stage Regression Results

\begin{tabular}{|c|c|c|c|}
\hline Log Productivity & Coefficient & $\begin{array}{l}\text { Robust } \\
\text { Std. Err }\end{array}$ & $\mathrm{t}$ \\
\hline Log Fragmentation & .3563144 & .0862625 & 4.13 \\
\hline Log Household Size & .3110634 & .0474749 & 6.55 \\
\hline Log Area Devoted to Crops & -.440312 & .0268089 & -16.42 \\
\hline Distance & .1616936 & .068846 & 2.35 \\
\hline Education 3 & .0840689 & .0694753 & 1.21 \\
\hline Education 2 & .0492124 & .0705679 & 0.70 \\
\hline Education 1 & -.1605755 & .1196998 & -1.34 \\
\hline Transportation & .2678858 & .0796651 & 3.36 \\
\hline Machinery & -.0155631 & .0757783 & -0.21 \\
\hline Fertilizers & .2972321 & .0667914 & 4.45 \\
\hline Non-farm Income & .0000417 & .0000317 & 1.31 \\
\hline Gender & .0715996 & .0612565 & 1.17 \\
\hline Constant & 4.452507 & .1792808 & 24.84 \\
\hline District 27 & -.6387853 & .1999502 & -3.19 \\
\hline District 26 & .0959714 & .1521324 & 0.63 \\
\hline District 25 & -.3990492 & .1691652 & -2.36 \\
\hline District 24 & -.3376076 & .1961932 & -1.72 \\
\hline District 23 & -.1275517 & .1914272 & -0.67 \\
\hline District 22 & -.2731953 & .1747438 & -1.56 \\
\hline District 21 & -.4261887 & .1936282 & -2.20 \\
\hline District 20 & .1659492 & .1790359 & 0.93 \\
\hline District 19 & -.0398069 & .1664183 & -0.24 \\
\hline District 18 & -.2064021 & .160071 & -1.29 \\
\hline District 17 & -.4903061 & .1698226 & -2.89 \\
\hline District 16 & -.4765339 & .1481074 & -3.22 \\
\hline District 15 & -.3456289 & .2039621 & -1.69 \\
\hline District 14 & -.4028371 & .16599 & -2.43 \\
\hline District 13 & -.1993165 & .187905 & -1.06 \\
\hline District 12 & .1298532 & .1582025 & 0.82 \\
\hline District 11 & -.3970174 & .1672164 & -2.37 \\
\hline District 10 & -.0005739 & .1768883 & -0.00 \\
\hline District 9 & -.4807666 & 1929729 & -2.49 \\
\hline District 8 & .1115116 & .1593637 & 0.70 \\
\hline District 7 & -.8412564 & .1521121 & -5.53 \\
\hline District 6 & -.8326291 & .1883082 & -4.42 \\
\hline District 5 & .0621682 & .1619547 & 0.38 \\
\hline District 4 & .0334343 & .1388631 & 0.24 \\
\hline District 3 & -.3623853 & .1589904 & -2.28 \\
\hline District 2 & -.1829074 & .1535787 & -1.19 \\
\hline District 1 & .169844 & .151893 & 1.12 \\
\hline
\end{tabular}


Instrumented: Log Fragmentation

Included instruments: Log Farm Size; Log Household Size; Log Area Devoted to Crops; Districts; Distance; Education 3; Education 2; Education 1; Transportation; Machinery; Fertilizers; Non-Farm Income; Gender.

Tests of endogeneity of: Log Fragmentation $\mathrm{H} 0$ : Regressor is exogenous

Wu-Hausman F test: $8.95934 \quad F(1,1252) \quad$ P-value: 0.00281

Durbin-Wu-Hausman chi-sq test: $\quad 9.18699 \quad$ Chi-sq(1) P-value: 0.00244 
Table 12 First-stage Regression

Simmons Index is used as the measure of fragmentation

Number of observations: $\quad 1293$

$\mathrm{F}(39,1253)$ : $\quad 14.06$

Prob > F: $\quad 0.0000$

R-squared: $\quad 0.2738$

Adj R-squared: $\quad 0.2511$

Log Simmons Index Coefficient Std. Err. $\quad t$

$\begin{array}{llll}\text { Log Area Devoted to Crops } & -.0546027 & .008164 & -6.69\end{array}$

$\begin{array}{llll}\text { Log Household Size } & -.009467 & .0154899 & -0.61\end{array}$

$\begin{array}{llll}\text { Log Farm Size } & -.0331299 & .0057622 & -5.75\end{array}$

$\begin{array}{llll}\text { Gender } & -.0081053 & .0201136 & -0.40\end{array}$

Non-Farm Income $\quad-1.16 \mathrm{e}-06 \quad .000011 \quad-0.11$

$\begin{array}{llll}\text { Fertilizer } & -.0464909 & .0223545 & -2.08\end{array}$

$\begin{array}{llll}\text { Machinery } & .0074518 & .0343686 & 0.22\end{array}$

$\begin{array}{llll}\text { Transportation } & -.0024823 & .0322502 & -0.08\end{array}$

$\begin{array}{llll}\text { Education } 1 & .0071689 & .0369604 & 0.19\end{array}$

$\begin{array}{llll}\text { Education } 2 & -.0020455 & .0261293 & -0.08\end{array}$

$\begin{array}{llll}\text { Education } 3 & -.0052391 & .0259012 & -0.20\end{array}$

$\begin{array}{llll}\text { Distance } & -.0466486 & .0233208 & -2.00\end{array}$

$\begin{array}{llll}\text { Constant } & -.1800299 & .0671455 & -2.68\end{array}$


Table 13 Second-stage Regression Results

\begin{tabular}{|c|c|c|c|}
\hline Log Productivity & Coefficient & $\begin{array}{l}\text { Robust } \\
\text { Std. Err. }\end{array}$ & $\mathrm{t}$ \\
\hline Log Simmons Index & -2.248448 & .6727069 & -3.34 \\
\hline Log Area Devoted to Crops & -.5547419 & .0580626 & -9.55 \\
\hline Log Household Size & .299952 & .0571887 & 5.240 \\
\hline District 1 & .052486 & .2238661 & 0.230 \\
\hline District 2 & .0012567 & .2380291 & 0.010 \\
\hline District 3 & -.1660309 & .2384335 & -0.70 \\
\hline District 4 & .207728 & .2222551 & 0.930 \\
\hline District 5 & -.3863829 & .2860588 & -1.35 \\
\hline District 6 & -.8988309 & .2405677 & -3.74 \\
\hline District 7 & -1.235154 & .2803335 & -4.41 \\
\hline District 8 & .0150704 & .2635084 & 0.060 \\
\hline District 9 & -.7913479 & .312364 & -2.53 \\
\hline District 10 & -.4309354 & .2920948 & -1.48 \\
\hline District 11 & -.617389 & .2768753 & -2.23 \\
\hline District 12 & .2486801 & .2362779 & 1.050 \\
\hline District 13 & -.2242095 & .2526636 & -0.89 \\
\hline District 14 & -.5005051 & .2356321 & -2.12 \\
\hline District 15 & -.2002152 & .2670798 & -0.75 \\
\hline District 16 & -.4034295 & .2366438 & -1.70 \\
\hline District 17 & -.5317814 & .2428416 & -2.19 \\
\hline District 18 & -.1199007 & .2303258 & -0.52 \\
\hline District 19 & -.1259507 & .2435765 & -0.52 \\
\hline District 20 & -.1137663 & .2760652 & -0.41 \\
\hline District 21 & -.4128881 & .257886 & -1.60 \\
\hline District 22 & -.2807715 & .2361606 & -1.19 \\
\hline District 23 & .0767099 & .2517202 & 0.300 \\
\hline District 24 & -.6662617 & .3406554 & -1.96 \\
\hline District 25 & -.243017 & .2494107 & -0.97 \\
\hline Districtr26 & .2314884 & .2332198 & 0.990 \\
\hline District 27 & -.5327508 & .2843898 & -1.87 \\
\hline Gender & .0500913 & .0749503 & 0.670 \\
\hline Non-farm Income & .0000404 & .0000391 & 1.030 \\
\hline Fertilizer & .2163018 & .0858798 & 2.520 \\
\hline Machinery & .0068511 & .1013546 & 0.070 \\
\hline Transportation & .2651749 & .1033308 & 2.570 \\
\hline Education 1 & -.1657227 & .1371725 & -1.21 \\
\hline Education 2 & .0343854 & .0903461 & 0.380 \\
\hline Education 3 & .0726551 & .0884933 & 0.820 \\
\hline Distance & .0958664 & .0843199 & 1.140 \\
\hline Constant & 4.138641 & .2965282 & 13.96 \\
\hline
\end{tabular}


Instrumented: Log Simmons Index

Instruments: Log Farm Size; Log Household Size; Log Area Devoted to Crops; Districts; Distance; Education 3; Education 2; Education 1; Transportation; Machinery; Fertilizers; Non-Farm Income; and Gender.

Tests of endogeneity of: Log Simmons Index $\mathrm{H} 0$ : Regressor is exogenous

Wu-Hausman F test: 15.53247 $\quad F(1,1252) P$-value $=0.00009$

Durbin-Wu-Hausman chi-sq test: $15.84455 \quad$ Chi-sq(1) P-value $=0.00007$ 
Data Appendix 


\section{Introduction}

As indicated in Essay II, the data used in this study is obtained from the 2003 Multi-topic Household Survey (MHS) conducted by the National Statistical Institute of Bulgaria (NSI) during October - November 2003. The 2003 MHS is a nationally representative survey covering information for a sample of 3023 families from across the 28 districts of the country. The 3023 households are comprised of 8250 individuals.

The subject matter of Essay II of the dissertation is the study of land fragmentation and its impacts on agricultural land productivity. Therefore, the households of interest are those who hold land, either owners or renters. Land related data is included in Module 4: Agriculture of the MSH and constitute a relatively small part of the survey. As a first step, it was necessary to extract the land related information from the raw data on agriculture. In other words, it was first necessary to select those households who own or rent land. Subsequently, it was necessary to extract other agriculture and household data for this particular sample of households. The procedure required a series of rather complicated selection techniques, conversions, transformations, and computations. This extensive data appendix attempts to describe how the data used in this study was obtained from the survey by specifying the steps of computing and/or transforming the variables included in the model. 


\section{The Variables}

The following variables are used in the econometric model specified in Essay II:

\section{The Dependent Variable}

$\mathbf{Y}_{\mathbf{i}}: \quad$ the dependent variable defined at the parcel level is land productivity measured as the total value of harvested crops per decare.

\section{Explanatory Variables}

The first important explanatory variable is farm fragmentation F, defined at the household level and measured at the household level both by the Simmons Index and the number of parcels per household. The Simmons Index $(\mathrm{SI})=\left(\sum_{i} A_{i}^{2} / A^{2}\right)$ where $\mathrm{A}_{\mathrm{i}}$ is the area of the $\mathrm{i}^{\text {th }}$ parcel and $\mathrm{A}$ is the total farm size.

$\mathbf{X}_{1:}$ : defined at the parcel level, this set of explanatory variables comprises parcel specific characteristics such as a distance dummy $\left(\mathrm{X}_{1,1}\right)$, area devoted to crops $\left(\mathrm{X}_{1,2}\right)$, use of fertilizers $\left(\mathrm{X}_{1,3}\right)$, use of machinery $\left(\mathrm{X}_{1,4}\right)$, and use of transportation $\left(\mathrm{X}_{1,5}\right)$.

$\mathbf{X}_{2}$ : defined at the household level, this set includes household specific characteristics such as household size $\left(X_{2,1}\right)$, gender of the head of household $\left(X_{2,2}\right)$, household head's education level $\left(\mathrm{X}_{2,3} \ldots \mathrm{X}_{2,5}\right)$, and non-farm income $\left(\mathrm{X}_{2,6}\right)$. 
$\mathbf{X}_{\mathbf{3}}$ : defined at the district level, this is a set of district dummies the inclusion of which is intended to capture the effects of prices, the efficiency of local land, labour, credit, and food markets, as well as the topographic diversity.

\section{Creating the Relevant Subset of Survey Data}

In Module 4: Agriculture of the MHS there are 3023 household entries. Some of these households indicate that they own land, some indicate that they rent land, some report that they both own and rent land, and yet another group reports that they neither own nor rent land. To create the relevant subset of survey data, from the 3023 household entries in Module 4 of the MHS, only those households who own land were selected. As explained in Section IV of the essay, the number of households who rent land was excluded since they constituted a very small subset of 23 entries. Deleting the families with no land holding association resulted in a set of 1736 households who operated some amount of land holdings. Descriptive statistics on fragmentation, number of parcels, size and number of farms, and other indicators presented in Section IV were calculated based precisely on this sample.

From the 1736 selected households, however, 440 households (more than 25 percent of the sample), did not cultivate their lands. For the purposes of the model, the 440 households whose land was reported to be left idle were deleted from the sample of 1736 since their presence would lead to misleading estimation and regression results. In addition three of the households owned farms of size significantly larger than the sample average - 600,800 , and 1200 as opposed to the average of 12.41 . With the exclusion of 
the 443 households, the final sample used in the regression estimations consists of 1293 households.

\section{Deriving Data for the Individual Variables}

Land productivity $\boldsymbol{Y}_{i}$. The dependent variable of the model, land productivity $\mathrm{Y}_{\mathrm{i}}$, is measured as the total value of all harvested crops divided by the total planted area of these crops. In order to obtain this variable, a complicated calculation involving reported prices and outputs was required. The first step was the computation of the total value of all crops.

The MHS includes codes for 24 crop types of which 5 were excluded as insignificant for the estimation of the model. ${ }^{171}$ The 19 crop types are Wheat, Maize, Other Cereals, Potato, Beans, Tomato, Cucumber, Cabbage, Pepper, Onions, Other Vegetables, Apples and Pears, Grapes, Watermelon, Sunflower, Tobacco, Forage, Nursery Plants, and Other Crops. The survey has data on (1) the harvested amounts in kilograms ${ }^{172}$ for households if they harvested any of the above listed crops; (2) the amount of land measured in decares and used for the crop in question; (3) the amount sold in kilograms; (4) the payment received for the whole amount of harvest sold, not per kilogram; and (5) the purposes for which harvested produce were used.

It is worth noting that the amounts harvested and the amounts sold are different. Farmers, the majority of whom are rather small landholders, are not selling their entire limited

\footnotetext{
${ }^{171}$ The excluded crops are Rye, Soybeans, Plums, and Other Fruits. Very few farmers grew these types of crops. 1 Kilogram $\approx 2.2 \mathrm{lbs}$
} 
amount of harvest since, as the data show, they seem to produce it primarily for the purposes of their own consumption. The harvested amounts can also be used for other purposes such as, to pay in kind, to feed livestock, poultry, and other animals, as gift to relatives and friends, and for future consumption. ${ }^{173}$ This creates a difficulty to set a price level to compute the total value of all harvest produced.

In order to establish the price levels shown in Table A1 (at the end of this appendix), the following procedure has been employed. For each crop and for the whole sample, the total amount in kilograms sold is added together and then the total payment amount collected is recorded. Dividing the total payment amount by the total kilogram amount sold would yield an average price per kilogram for the crop in question. This process may be called a weighted average. The other alternative of consideration could be the use of median price level. However, the median price level approach is considered inappropriate for the model since it requires that the frequency of the available prices is supportive of the median use and this is not the case for the survey data.

Nonetheless, for reference purposes, median prices are also computed and they appear to be not much different from the numbers used in the model. Using a weighted average is especially important when observations indicate significant price differences in regions, as well as price differences due to the differences in the amount sold. To give an example from the survey, if the total amount of corn sold is 120 kilograms, then the price per kilogram is $0.41 \mathrm{BGN}$; on the other hand, for 600 kilograms sold, the price is $0.3 \mathrm{BGN}$,

\footnotetext{
${ }^{173}$ The store of fruits and vegetables is possible through the preparation of canned food to be consumed in the winter, which is a common tradition in Bulgaria. Other harvest is also stored for use in the winter.
} 
for 5000 kilograms, the price is $0.2 \mathrm{BGN}$, for 10000 kilograms the price is $0.17 \mathrm{BGN}$, and for 29000 kilograms the price is 0.12 BGN per kilogram.

Similarly, some price differences are expected when a product is produced and sold in regions near big cities, compared to remote agricultural regions. It is also worth noting that obtaining or computing prices on the district level is not possible because there are several districts where crops were not sold at all and so those districts have no price information. This is not surprising because in many cases the small average size of plots allows an amount of produce just enough for subsistence or household consumption.

After establishing a price per kilogram price for the 19 crops included in the model, the total value of crops produced by a household can easily be computed. This is done simply by adding the land (in decares) devoted to individual crops together for each household and dividing the total value of all crops produced by a household with the total area devoted to the crop, in decares. The outcome is the total value of harvested crops per decare, which is $\mathrm{Yi}$, the land productivity measure of the model.

Household Size. The MHS does not directly provide the household size. Since the survey is conducted on a household basis where each and every individual in the household is surveyed, it was complicated but still possible to obtain the household size information. Module 1 of the survey assigned a number to every individual surveyed, and every individual also has a household number. Therefore, in order to find out the household size, it was necessary to add up the number of individuals surveyed as long as the 
household number was unchanged. This required the classification of 8250 individuals into 3023. Integrating the information for ownership of land from Module 4 into Module 1 allowed again the exclusion of those households who did not own or rent land.

Gender of the Household Head. In Module 1, the first member of each household is defined as the household head. Therefore, the gender of the first person surveyed in each household was recorded. Gender of the household head enters the model as a dummy variable, such that, if the head of the household is male, it takes the value of one and if it is female, it takes the value of zero.

Household Head's Education. The education of the household head is used as one of the household characteristic variables. Obtaining this information required the integration of data from Modules 1, 4, and 8 of the survey. Module 8 provides information for the education status of the 8250 individuals surveyed in the MHS. The education information for the household heads was classified into four different education variable categories.

The first category includes both those who have only elementary school education or the ones who had not completed elementary school. This is the lowest educational category. The second category consists of the middle school graduates, the third category includes high school graduates, and the fourth category is comprised of university, college or graduate school graduates. The education of the household head enters the model as a set of dummy variables. Since there are four distinct categories for the education of the head of the household, three dummy variables are used in the model. 
The first dummy variable is for those holding undergraduate or graduate degrees. It takes the value of one if the household head holds an undergraduate or a graduate degree; otherwise its value is set to zero. The second educational dummy variable is for those who hold a high school diploma. If the household head holds a high school diploma, then the value is one, otherwise it is zero. The third educational dummy variable is for those with middle school education. If the household head has a middle school degree, then the variable has the value of one, otherwise, it is equal to zero.If the first three dummy variables have the value of zero simultaneously, this would imply that the head of the household falls into the last category - elementary school education or incomplete elementary school education.

Farm Size. The total farm size is not provided in the survey. However, it was easy to compute this variable since the survey records the number of plots each household owns, along with various information related to each plot. The observed number of plots owned or rented by households surveyed in the MHS range from 1 to 6 and they are numbered correspondingly. In addition to the maximum of 6 possible plots per household, the survey lists "yard" separately. For the purposes of this study, yard is added to the number of plots - so a household with a yard and one plot would be considered as a fragmented farm. Therefore, the number of parcels each household in the sample of 1736 can have ranges from the minimum of one to the maximum of seven. The size of each plot is recorded in the MHS which allows for the easy calculation of farm sizes. To obtain the farm size of a household, the sizes of all reported pieces of lands in decares are added up for each of the 1736 households. 
Total Area Devoted to Crop. In addition to the farm size variable explained above, the model also requires the total area devoted to crops, as some households may not use all of its land for crop production. This can only be computed by using the production section of Module 4 of the survey. As explained in the above discussion of the land productivity variable, the survey has crop-specific data on the area devoted to the 19 types of crops. Adding up the areas used for specific crops (in decares) yields the total area devoted to crop for each family. Naturally, the total area devoted to crop will always be less than or equal to the farm size for any given household.

Number of Parcels per Household. This is the alternative measure of the fragmentation variable. This information is again not readily available. However, as noted above, the survey has individual parcel information for each family; therefore, the simple summation of all parcels yields the total number of parcels per household.

Average Parcel Size. Once the total number of parcels and the farm size for each household is obtained, it is easy to have the average parcel size by dividing the farm size with the total number of parcels for each household.

The Simmons Index. The Simmons Index $=\left(\sum_{i} A_{i}^{2} / A^{2}\right)$ where $A_{\mathrm{i}}$ is the area of the $i^{\text {th }}$ parcel and A is the total farm size. For each household, the sum of the squares of the size of each parcel were calculated and then divided by the square of the total size of these parcels. 
Non-farm Income. This information is derived from the Regular Income section of Module 5 of the MHS. The non-farm income, if available, for each household is computed as the sum of the following eight categories of regular income listed in the module: second job earnings, unemployment benefits, retirement pension, heir's pension, disability pension, other pensions, family allowances, and scholarship. Income figures in the study are in Bulgarian Leva (BGN).

Use of Credits. This variable is not included in the model but was initially intended to be a variable of consideration. As discussed in Section IV, examination of Module 6 of the MHS revealed that none of the households uses credits for agriculture.

Use of Fertilizers. This is one of the parcel-specific characteristics variables and is readily available in Module 4. The survey asks whether or not a household uses fertilizers; the variable takes the value of one if fertilizers are used, and zero otherwise.

Use of Machinery. This is also a parcel-specific characteristic and is obtained directly from the survey. The survey asks whether or not a household owns or rents machinery for use in farming; the variable takes the value of one if machinery is owned or rented, and zero otherwise.

Use of Transportation. This is another parcel-specific characteristic variable obtained directly from the survey. The survey asks whether or not a household had had transportation-related expenditures for agricultural activities such as traveling to plots, 
transportation of equipment for tillage, planting, harvesting, storage, and sale of produce, transportation of fertilizers, pesticides, insecticides, and others. Use of Transportation takes the value of 1 if expenditures for transportation were made, and zero otherwise.

Distance. The MHS does not provide information with regard to the exact distance between the home and the parcel(s) or the distance between parcels. However, it does ask whether a plot is located inside or outside of the household's area of residence (city, town, or village). To account for the distance of parcels from the homestead of the household, a distance dummy variable was created to which a value of one is assigned when plots are located inside the household's area of residence (implying short distances) and a value of zero is assigned when the plot is located outside the household's area of residence (implying long distances).

Districts. Bulgaria is officially divided into 28 districts in which the MHS was conducted. The districts are listed and numbered in the Cyrillic alphabetical order as follows: 1 . Blagoevgrad 2. Burgas 3. Varna 4. Veliko Tarnovo 5. Vidin 6. Vratsa 7. Gabrovo 8. Kardzhali 9. Kyustendil 10. Lovech 11. Montana 12. Pazardzhik 13. Pernik 14. Pleven 15. Plovdiv 16. Razgrad 17. Ruse 18. Silistra 19. Sliven 20. Smolyan 21. Sofia City 22. Sofia Province 23. Stara Zagora 24. Dobrich 25. Targovishte 26. Haskovo 27. Shumen 28. Yambol. Since this is how the MHS numbers the districts, the order was kept the same in the study. The district variables numbered from 1 to 28 enter the model as 27 dummy variables in the following form: 
District Variable $\mathrm{X}$ takes the value of

$\begin{array}{ll}1 & \text { if household resides in district } X \quad X=1,2, \ldots, 27 \\ 0 & \text { otherwise }\end{array}$

District 28, Yambol, will be represented when the first 27 region variables take the value of zero simultaneously. Figure A1 at the end of the appendix illustrates the location and size of each district: 
Table A1 Prices Used in the Productivity Computation (BGN)

\begin{tabular}{|rlcc|}
\hline \multicolumn{1}{|c}{ Crop } & $\begin{array}{c}\text { Weighted } \\
\text { Average } \\
1\end{array}$ & 0.243 & Median \\
2 & Wheat & 0.215 & 0.250 \\
3 & Other Cereals & 0.149 & 0.200 \\
4 & Potato & 0.413 & 0.200 \\
5 & Beans & 1.929 & 0.440 \\
6 & Tomato & 0.276 & 2.000 \\
7 & Peppers & 0.424 & 0.330 \\
8 & Cucumber & 0.424 & 0.400 \\
9 & Cabbage & 0.326 & 0.500 \\
10 & Onions & 0.500 & 0.300 \\
11 & Other Vegetables & 0.931 & 0.500 \\
12 & Apples and Pears & 1.000 & 0.960 \\
13 & Grapes & 0.330 & 1.000 \\
14 & Watermelon & 0.500 & 0.350 \\
15 & Sunflower & 0.330 & 0.500 \\
16 & Tobacco & 3.244 & 0.340 \\
17 & Forage & 0.106 & 3.460 \\
18 & Nursery Plant & 1.739 & 0.070 \\
19 & Other Crops & 0.514 & 1.500 \\
\hline
\end{tabular}


Figure A1 Location and Size of Districts in Bulgaria

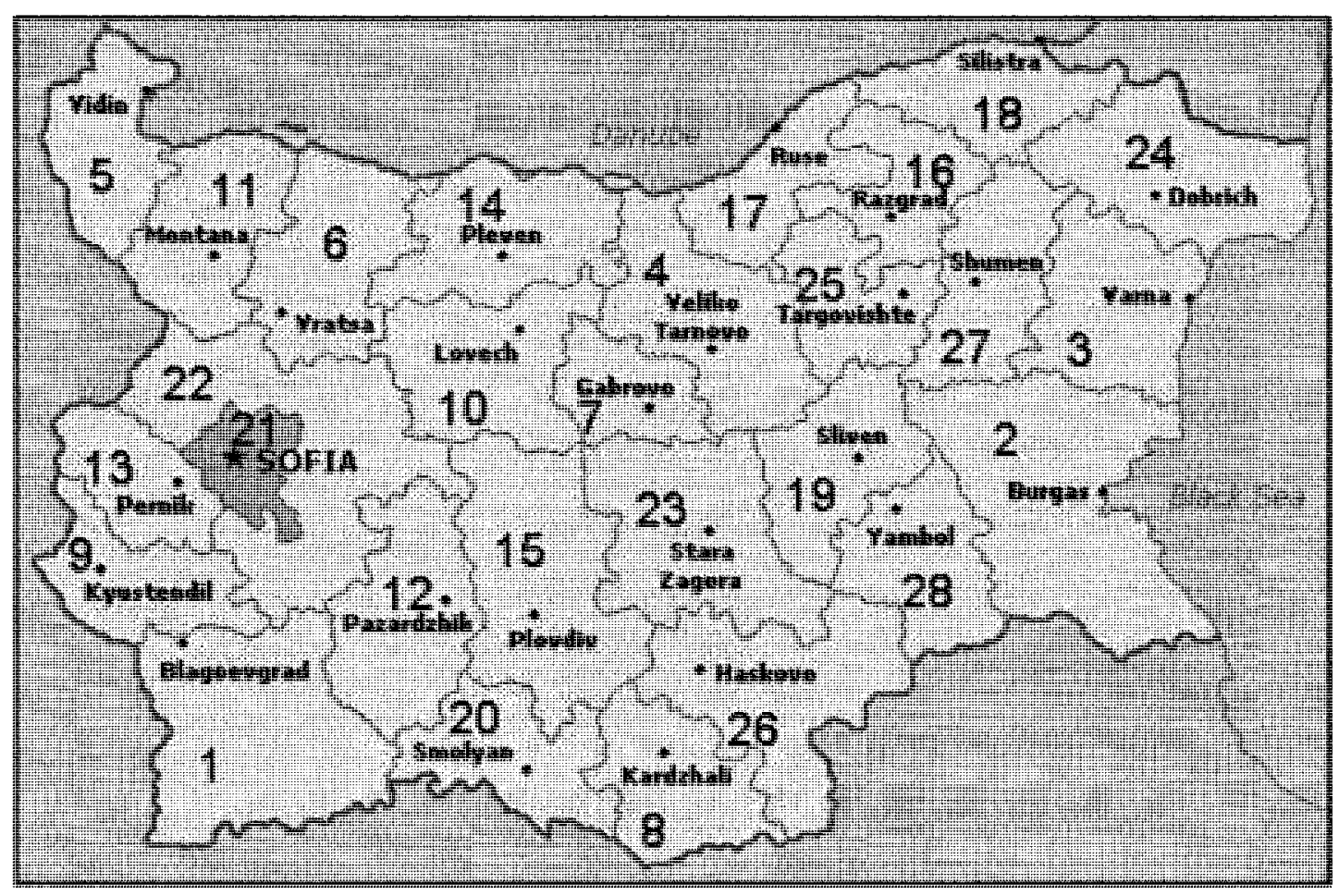

